NUREG/CR-3620

PNL-4054

Supplement No. 1

\title{
Intruder Dose Pathway Analysis for the Onsite Disposal of Radioactive Wastes: The ONSITE/MAXI1 Computer Program
}

Prepared by W. E. Kennedy, Jr., R. A. Peloquin, B. A. Napier/PNL S. M. Neuder/NRC

Pacific Northwest Laboratory Operated by

Battelle Memorial Institute

Prepared for

U.S. Nuclear Regulatory

Commission 


\section{NOTICE}

This report was prepared as an account of work sponsored by an agency of the United States Government. Neither the United States Government nor any agency thereof, or any of their employees, makes any warranty, expressed or implied, or assumes any legal liability of responsibility for any third party's use, or the results of such use, of any information, apparatus, product or process disclosed in this report, or represents that its use by such third party would not infringe privately owned rights.

\section{NOTICE}

\section{Availability of Reference Materials Cited in NRC Publications}

Most documents cited in NRC publications will be available from one of the following sources:

1. The NRC Public Document Room, 1717 H Street, N.W. Washington, DC 20555

2. The Superintendent of Documents, U.S. Government Printing O1fice, Post Office Box 37082 Washington, DC 20013-7082

3. The National Technical Information Service, Springfield, VA 22161

Although the listing that follows represents the majority of documents cited in NRC publications it is not intended to be exhaustive.

Referenced documents available for inspection and copying for a fee from the NRC Public Docu ment Room include NRC correspondence and internal NRC memoranda; NRC Office of Inspection and Enforcement bulletins, circulars, information notices, inspection and investigation notices: Licensee Event Reports; vendor reports and correspondence; Commission papers; and applicant and licensee documents and correspondence.

The following documents in the NUREG series are available for purchase from the GPO Sales Program: formal NRC staff and contractor reports, NRC-sponsored conference proceedings, and NRC booklets and brochures. Also available are Regulatory Guides, NRC regulations in the Code of Federal Regulations, and Nuclear Regulatory Commission Issuances.

Documents available from the National Technical Information Service include NUREG series reports and technical reports prepared by other federal agencies and reports prepared by the Atomic Energy Commission, forerunner agency to the Nuclear Regulatory Commission.

Documents available from public and special technical libraries include all open literature iterns, such as books, journal and periodical articles, and transactions. Federal Register notices, federal and state legislation, and congressional reports can usually be obtained from these libraries.

Documents such as theses, dissertations, foreign reports and translations, and non-NRC conference proceedings are available for purchase from the organization sponsoring the publication cited.

Single copies of NRC draft reports are available free, to the extent of supply, upon written request to the Division of Technical Information and Document Control, U.S. Nuclear Regulatory Com mission, Washington, DC 20555.

Copies of industry codes and standards used in a substantive manner in the NRC regulatory process are maintained at the NRC Library, 7920 Norfolk Avenue, Bethesda, Maryland, and are available there for reference use by the public. Codes and standards are usually copyrighted and may be purchased from the originating organization or, if they are American National Standards, from the American National Standards Institute, 1430 Broadway, New York, NY 10018. 
NUREG/CR-3620

PNL-4054

Supplement No. 1

\section{Intruder Dose Pathway Analysis for the Onsite Disposal of Radioactive Wastes: The ONSITE/MAXI1 Computer Program}

Manuscript Completed: April 1985

Date Published: May 1986

Prepared by

W. E. Kennedy, Jr., R. A. Peloquin, B. A. Napier, Pacific Northwest Laboratory

S. M. Neuder, U.S. Nuclear Regulatory Commission

Pacific Northwest Laboratory

Richland, WA 99352

Prepared for

Division of Waste Management

Office of Nuclear Material Safety and Safeguards

U.S. Nuclear Regulatory Commission

Washington, D.C. 20555

NRC FIN B2478 



\section{PREFACE}

The document entitied Intruder Dose Pathway Analys is of the Onsite Disposal of Radioactive Wastos: The ONSITE/MAXIl Computer Pregram (1984) by Napier et al. summarizes our initial efforts to develop human-intrusion scenarios and a modiffed version of the MAXI computer program for potential use by the NRC in reviewing applications for onsite radioactive waste disposal. This document is a supplement to that document and summarizes our efforts to further modify and improve the ONSITE/MAXII software package. To facilitate cross-referencing, it follows the same format. Notable improvements to the software package include the capability to account for shielding conditions that represent noncompacted trash wastes and the option to Indicate alternative 1 and-use conditions. This supplement contains a description of the implementation of these modifications. In addition, a series of discussions are included in an attempt to increase the user's understanding of the scenarios and dose calculation methods. These discussions respond to frequently asked questions about the mathematical models and use of the software.

Computer listings of the ONSITE/MAXIl computer program are included as Appendices $A$ and $B$ of this document. Appendix $C$ ilsts external exposure dose-rate factor 1 fbraries.

A second supplement to the 1984 NUREG document is planned for publication in late 1986. The second supplement will include ICRP-26/30 internal dose conversion factors and modifications for operations on a personal computer. 



\section{EXECUTIVE SUMMARY}

Pacific Northwest Laboratory prepared this document as a supplement to a previous document that describes the ONSITE/MAXIl computer sof tware package (Intruder Dose Pathway Analys is for the Onsite Disposal Radioactive Wastes: The ONSITE/MAXIl Computer Program, 1984, by Napier et a1.). The objective of this project is to modify an existing pathway-to-man computer program, the MAXI computer program, for use by the U.S. Nuclear Regulatory Commission (NRC) in reviewing all proposed onsite burials of radioactive materials by its 1 icensees. Because of uncertainties associated with assessing the potential risks from onsite burials of radioactive waste, the NRC amended its regulations to provide greater assurance that buried radioactive material wilT not present a hazard to public health and safety. The current policy of the NRC is to review all proposed onsite burials of radloactive waste on a case-by-case basis. As part of our earlier work on this project, specific human intrusion scenarios were developed that consider various potential combinations of direct exposure to penetrating radiation, inhalation of afrborne radionuclides, ingestion of agricultural products raised in contaminated soil, and ingestion of radionuclides in drinking water. These scenarios are activated by running the ONSITE/MAXIl computer software package.

As a continuation of our earlier efforts, enhancements to the ONSITE/MAXII computer software package and revisions to the documentation were made to more fully explain the computer software. The program enhancements account for additional optional shielding factors that could influence external exposure to penetrating radiation and provide options for alternative landuse conditions that permit the user to select from a complete diet, meat diet, or vegetable diet. Expanded descriptions of the radiation exposure scenarios and mathematical models are also included to assist the user in understanding the operation of the computer programs. These program enhancements and expanded model descriptions are discussed in Section 2 of this supplement.

The ONSITE/MAXIl software package has been installed on both $\operatorname{CDC}^{(a)} 6600-$ 7600 and $V A X^{(b)} 780$ computers, and the ONSITE computer program has also been installed on the IBM $(C)$ PC. The original documentation for the ONSITE/MAXIl software provided detailed instructions for operation on the CDC 6600-7600 computer (Napier et al. 1984). Section 3 of this document contains a description of the procedures used to operate the software on the VAX780 computer. A sample problem that demonstrates the stored waste sub-set of the External Exposure Scenario is also given in Section 3. Except for the system-level commands, the operation of the ONSITE/MAXI1

(a) CDC is a registered trademark of Control Data Corporation, St. Paul, Minnesota.

(b) VAX is a trademark of Digital Equipment Corporation, Nashua, New Hampshire.

(c) IBM is a registered trademark of International Business Machines Corporation. Boca Raton. Florida. 
software is identical on both the CDC and VAX computers, and full verification and test problems have been completed. The changes and enhancements made to the software have not altered the structure or operation of the computer programs; thus, the structure and operation discussed in Napler et a1. (1984) have not been repeated in this document. A complete listing of the MAXII and ONSITE computer programs along with a complete 1 isting of the the data libraries used to model a wide variety of external exposure conditions are provided in the appendices of the document. The organization of this supplement roughly follows the arrangement of the original ONSITE/MAXIl document to facilitate cross-referencing. 


\section{ACKNOWLEDGMENTS}

The authors would like to thank all of those individuals who helped make this study possible. The historical development of the MAXI computer program included major contributions from Ed Watson, Glenn Hoenes, and Joe Soldat of Pacific Northwest Laboratory. We greatiy appreciate the guidance, assistance, and encouragement offered by these individuals in the development of the methods and phflosophy applied in this report. We would like to thank Dave Hulzenga for his review of the ONSITE/MAXIl software package and documentation and Joe Soldat for his revfew of this manuscript. We appreciate the comments and critiques of other ONSITE/MAXIl users, and we attempted to respond to their questions in this report. We would also like to thank Norma Van Houten and Cathle Jordon for typing, correcting, and printing this manuscript, and Kathi Hanson for editing. 



\section{CONTENTS}

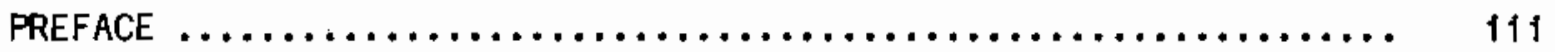

EXECUTIVE SUMMARY..............................

ACKNOWLEDGMENTS. ............................... vif

1.0 INTRODUCTION................................ 1.1

REFERENCES.................................... 1.2

2.0 MATHEMATICAL MODELS AND COMPUTER SOFTWARE FOR ASSESSING ONSITE DISPOSAL IMPACTS - ENHANCEMENTS AND FURTHER

DISCUSSIONS. ................................ 2.1

2.1 DEFINITION AND SOLUTION OF THE PROBLEM............. 2.1

2.1.1 Aiternative Land-Use Conditions.............. 2.2

2.1.2 Dfet Correction Factor and Area Correction Factor Relationship.......................... 2.2

2.1.3 Resuspension and Inhalation Area Correction Factor............................... 2.4

2.1.4 External Exposure Sensitivity Studies............ 2.4

2.1.5 Stored Waste Scenario Description............... 2.7

2.1.6 Comparison of Maximum Annuat Dose to Committed

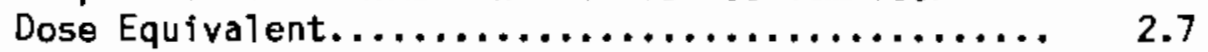

2.1.7 MAXI1 Time Line.......................... 2.14

2.1.8 Derivation of Area Correction Factors for Ingestion Pathway..................... 2.15

2.2 COMPUTER IMPLEMENTATION OF SCENARIO AND MODEL

ENHANCEMENTS ................................ 2.16

2.2.1 Expanded Land-Use and Diet Modification Options... 2.16

2.2.2 Waste Density Options for External Exposure....... 2.16

2.2.3 Incidental Surface Contamination for External

Exposure and Inhalation Pathways............. 2.17

2.2.4 Inhalation Area Correction Factor............. 2.18

2.3 DATA BASE EXPANSION....................... 2.18

2.3.1 Leaf Mechanism Dose-Rate Factors............... 2.18

2.3.2 So 11 Mechanism Dose-Rate Factors................. 2.18

2.3.3 Externa1-Exposure Mechanism Dose-Rate Factors..... 2. 2.19

REFERENCES.......................... 2.22 
3.0 PROCEDURES. $\ldots \ldots \ldots \ldots \ldots \ldots \ldots \ldots \ldots \ldots \ldots \ldots \ldots \ldots \ldots \ldots \ldots \ldots \ldots, 3.1$

3.1 USER INSTRUCTIONS FOR THE VAX COMPUTER............ 3.1

3.2 INPUT PARAMETERS - FURTHER DISCUSSION............. 3.2

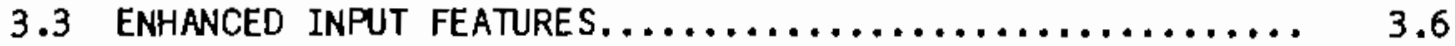

3.4 SAMPLE PROBLEM - STORED WASTE SCENARIO............. 3.6

REFERENCES............................... 3.9

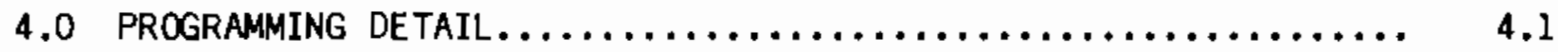
REFERENCES................................ 4.1

5.0 ERRATA................................... 5.1

5.1 UNIT CONYERSIONS - ONSITE................... 5.1

5.2 RUTHENIUM-103 DECAY CHAIN - RMDLIB/RMDONS............ 5.1

5.3 STRONTIUM-90 - ORGLIB....................... 5.1

REFERENCES............................... 5.1

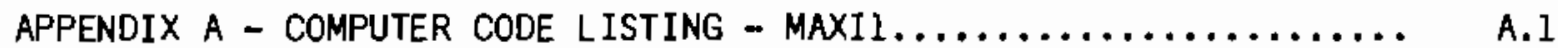

APPENDIX B - COMPUTER CODE LISTING - ONSITE................ B.I

APPENDIX C - EXTERNAL EXPOSURE DOSE RATE FACTOR LIBRARIES........ 


\section{EIGURES}

2.1-1 Area Correction Factors for the External Exposure and

Inhalation Pathways........................... 2.5

2.1-2 Area Correction Factors for the Ingestion Pathway......... 2.5

2.1-3 Equaltty Between the Dose Conmitment and the Annual Dose Under Continuous Exposure Conditions of Constant Annual

Intake....................................... 2.12

2.1-4 MAXIl Time Line.............................. 2.15

2.2-1 Example of the ONSITE Diet Option Input Screen........... 2.16

2.2-2 Example of the ONSITE Waste Density Option Input Screen.... $\quad 2.17$

2.2-3 Example of the ONSITE External Exposure Option Input Screen ..................................... 2.17

3.2-1 Revised ONSITE Input Screen for Radionuclide Inventory Modiffcation Factor - SRDIL..................... 3.5

3.2-2 Revised ONSITE Input Screen for Sol1 Contamination Distribution Parameter - RPFI.................... 3.5

3.3-1 Input Screen of Radionuclides Considered in the ONSITE/MAXIl Software Package...................... 3.8

3.4-1 Input for the Stored Waste Scenarfo Sample Problem......... 3.10

3.4-2 Output from the Stored Waste Scenarto Sample Problem....... 3.18 


\section{TABLES}

2.1-1 Fractional Contribution of Meat and Vegetable Diet to Total-Body Dose-Rate Factors During the First Year of

Exposure for Selected Radionuclides.................. 2.3

2.1-2 Results of Sample Problem Three for the Three Land-Use

Diet Options................................... 2.3

2.1-3 Sensitivity Study Results for the External Exposure Pathway - mrem/hr per $\mathrm{C} 1 / \mathrm{m}^{3}$ for Selected Waste Form Densities and $S l a b$ Thicknesses with 0.0 m Overburden....... 2.6

2.1-4 Comparison of 10 CFR Part 61 and Calculated Low-Level Waste Disposal Concentrations...................... 2.14

2.3-1 Dose-Rate Factor Files for Externa] Exposure............. 2.20

2.3-2 ISOSHLD Parameter Values Used for External Dose-Rate Factors...................................... 2.21

3.2-1 Scenario Default Parameter values................... 3.3

3.2-2 Sample Problem Parameter Values................... 3.4

3.2-3 ONSITE/MAXIl Parameter Descriptions................. 3.6 


\subsection{INTRODUCTION}

In January 1981, the U.S. Nuclear Regulatory Commission (NRC) amended its regulation in order to minimize the risks associated ith onsite 1 and disposal of radloactive materials by IIcensees. Current regulations require that disposal of radioactive materials by licensees, unless otherwise authorized, be specifically approved by the NRC pursuant to Section 20.302(a) of 10 CFR Part 20 (NRC 1984). This regulation states:

Any licensee or applicant for a 1 icense may apply to the Commission for approval of proposed procedures to dispose of licensed material in a manner not otherwise authorized in the regulations in this chapter. Each application should include a description of the 1 icensed material and any other radioactive material involved, including the quantities and kinds of such material and the levels of radioactivity involved, and the proposed manner and conditions of disposat. The application should also include an analysis and evaluation of pertinent information as to the nature of the environment, including topographical, geological, meteorological, and hydrological charactertstics; usage of ground and surface waters in the general area; the nature and locations of other potentially affected faclitities; and procedures to be observed to minimize the risk of unexpected or hazardous exposures.

The current policy of the NRC is to review all proposed onsite burials on a case-by-case basis. Technical assessments of proposed onsite disposals may at times require modeling of the potential pathways to man and projecting the magnitude of potential radiation dose commitments. The objective of this project is to modify an existing pathway-to-man computer program, MAXII (Napier et a]. 1979), for use by the NRC Waste Management staff when they conduct human-intrusion, dose-pathway analyses for onsite burial of low-level radioactive wastes. As part of an earlier effort on this project, specific human-intrusion scenarios were developed for various potential combinations of direct exposure to penetrating radiation, inhalation of alrborne radionuclides, ingestion of agricultural products raised in contaminated soil, and ingestion of radionuclides in drinking water (Napier et al. 1984). These scenarlos are activated by running the ONSITE/MAXII computer software package. As a continuation of earlier work, enhancements to the ONSITE/MAXII computer software package and revisions to the documentation have been made to explain the computer software. Program enhancements add optional shielding factors in the direct exposure pathway scenarios and options for alternative land-use conditions that permit the user to select from a combined dlet, meat diet, or vegetable diet.

The ONSITE/MAXIl software package contains four computer codes. ONSITE is the interactive user interface that allows the end-user to simply and efficiently create and use the radiation exposure scenartos. MAXIl is then used with the scenario information to calculate the maximum annual dose to 
the exposed individual from selected pathways. MAXI2 generates intermediate dose-conversion factors for food pathways. These factors are stored in data files. MAXI3 generates the data files containing intermediate dose-conversion factors for aquatic pathways.

In addition, data files are provided that contain inhalation and external dose-conversion factors. These factors are calculated using codes external to the ONSITE/MAXIl software package. The inhalation dose-conversion factors are based on the Task Group on Lung Dynamics Model (TGLM) and revisions to the metabolic data for plutonium and other actinides developed by the International Commission on Radiological Protection (ICRP 1966; ICRP 1972). They are calculated using a version of the DACRIN (Houston, Strenge and Watson 1974) computer program. The external dose-conversion factors for various waste disposal geometries and conditions are calculated using the ISOSHLD (Engel, Greenborg and Hendrickson 1966) shielding program.

This supplement to Napler et al. (1984) describes the enhancements added to the ONSITE/MAXIl software package since the original document was published in October 1984. Notable improvements to the software package include the ability to account for shielding conditions that represent noncompacted trash wastes and the option to indicate alternative land-use conditions. Expanded descriptions of the scenarios and mathematical models are also included to assist the user in understanding the operation of the computer programs.

The organization of this supplement closeiy follows the outline of Napier et al. (1984). To facilitate cross-referencing, major sections of the two documents are parallel. Appendices in this supplement contain the current listings of all external dose-rate factor files and the modifled verstons of the ONSITE and MAXII computer programs.

\section{REFERENCES}

Engel, R. L., J. Greenborg, and M. M. Hendrickson. 1966. ISOSHLD $=$ A Computer Code for General. Purpose Isotope Shjelding Analysis. BNWL-236, Pacific Northwest Laboratory, Richland, Washington.

Houston, J. R., D. L. Strenge and E. C. Watson. 1974. DACRIN-A Computer Program for Calculating Organ Dose from Acute or Chronic Radionuclide Inhalation. BNwL-B-389, Pacific Northwest Laboratory, Richland, Washington.

ICRP (International Commission on Radiological Protection). 1966. "Task Group on Lung Dynamics for Committee II of the International Comission on Radiological Protection." Health Physics, Vol. 12, p. 173, Pergamon Press, Oxford, England. 
ICRP (International Commission on Radiological Protection). 1972. The Metabolism of Compounds of Plutonium and Other Actinides. ICRP Publication 19, Pergamon Press, Oxford, England.

Napier, B. A., G. R. Hoenes, W. E. Kennedy, J.., and E. C. Watson. 1979. "The Maximum Annua] Dose Resulting from Residual Radioactive Contamination." Paper presented at the 24 th Annual Meeting of the Health Physics Soclety, July 8-13, 1979, Philadelphia, Pennsylvania. PNL-SA-7496. Pacific Northwest Laboratory, Richland, Washington.

Napier, B. A., R. A. Peloquín, W. E. Kennedy, Jr., and S. M. Neuder. 1984. Intruder Dose Pathway Anay] sis for the Onsite Disposal of Radjaactive Wastes: The ONSIIE/MAXIl Computer Program. NUREG/CR-3620, PNL 4054. U.S. Nuclear Regulatory Commission, Washington, D.C.

NRC. 1984. Standards for Protection Against Radiation. Title 10, Code of Federal Regulations - Energy, Part 20. U.S. Nuclear Regulatory Commission, Washington, D.C. 



\subsection{MATHEMATICAL MODELS AND COMPUTER SOFTWARE FOR ASSESSING ONSITE DISPOSAL IMPACTS - ENHANCEMENTS AND FURTHER DISCUSSIONS}

This section discusses enhancements to the radiation-exposure scenarios, mathematical models, computer programs, and data bases for assessing potential doses to intruders of onsite disposal sites as presented in Napler et a). (1984).

\subsection{DEFINIIION AND SOLUIION OF THE PROBLEM}

As described in Napier et a1. (1984), an approach similar to that applied in the Draft and Final Environmental Impact Statement in support of 10 CFR Part 61 (NRC 1981; NRC 1982) is used to assess risks associated with onsite disposal. That is, radiation-exposure scenarios for the maximally exposed individual (an intruder) are established and the resulting radiation dose is determined.

Five scenarios are identified for assessing doses to intruders at onsite disposat sites.

1. External-Exposure Scenario. An individual is assumed to work in an area previously used for onsite disposal. Only external exposure to direct penetrating radiation is considered. Optional data libraries permit the user to select from surface-soil contamination, wastes burled at depths of $0.5 \mathrm{~m}$ or $1.0 \mathrm{~m}$, or entry into a room (or vault) that is used for waste storage or disposat. A sub-set of this scenario is the Stored Waste Scenario, which is described in detafl in Section 2.1.5.

2. External Exposure Plus Inhalation Scenario. An individual is assumed to work in an area with 1 imited surface-soli contamination. This individual is exposed to di rect penetrating radiation and inhales resuspended radionuclides that are present in the surface sofl.

3. Agricultural Scenario. An individuat is assumed to raise his annual diet (or a fraction of $1 t$ ) in 5011 contaminated by the onsite disposal of radioactive wastes. External exposure and inhalation of resuspended radionuclides from surface soll are also constdered.

4. Irrigation/Drinking-kater Scenario. An individual is assumed to irrigate and/or orink from a water supply contaminated by radionuclides from an onsite disposal site. In addition, external exposure and inhalation of resuspended radionuclides that are deposited on the surface of the soll by the irrigation water are considered.

5. User-Defined Scenario. The user may construct hts own scenario by selecting exposure pathways and defining conditions described in the ONSITE/MAXII computer software package. 
The remainder of this section describes the enhancements that have been made to the original ONSITE/MAXIl computer software package.

\subsubsection{Alternative Land-Use Conditions}

Additional agricultural scenarlo options have been developed to consider alternative iand-use conditions. The original agricultural scenarfo assumed the intruder raised vegetables, fruit, and livestock for meat and dairy products on the waste disposal site. This original scenario is referred to as the combined diet option. Two aiternative types of land-use may now be considered by the software user. The first alternative land-use option, referred to as vegetable diet option, assumes the intruder grows only vegetables and fruits on the waste disposal site. The second alternative land-use option assumes the intruder uses the waste disposal site only for grazing of livestock. In this second option, referred to as the meat diet option, the intruder's diet consists of meat and dairy products obtained from the livestock raised on the disposal site.

Diet parameters are "environment"-specific in that intruder diet parameters are used to calculate dose-conversion factors that are subsequently used in the onsite disposal scenarios (Napier et al. 1984, Sections 2.1.1 and 2.1.2). Diet parameters are reflected in the leaf and soll mechanism doserate factors [Napier et a1. 1984, Equation (2.9)] used by MAXIl. In order to $1 \mathrm{mplement}$ the alternative land-use conditions, additional files of leaf mechanism dose-rate factors (Napier et al. 1984, Section 2.3.2) and soil mechanism dose-rate factors (Napier et al. 1984, Section 2.3.3) were developed. The parameters used to generate these dose-rate factors for selected foods are listed in Napier et a1. (1984, Table 2.1-1). The vegetable diet option consists of leafy, other aboveground, and root vegetables as well as fruits and grains. The meat diet option consists of eggs, milk, beef, pork, and poultry. The implementation of the additional agricultural land-use options into the ONSITE/MAXIl software package is further discussed in Section 2.2.1.

The diets considered in the alternative land-use options have been shown to affect the doses resulting from the agricultural scenario. Table 2.1-1 contains the fractional contribution of the meat and vegetable diet to total-body dose-rate factors during the first year of exposure for selected radionuclides. Selecting the vegetable diet option or the meat diet option may change the magnitude of the organ dose, the domfnant pathway, the dominant radionuclide in a given mixture, and the year of maximum exposure. To demonstrate these possible changes, Table 2.1-2 summarizes the results of Sample Problem Three (Napier et a1. 1984) when executed with the the meat diet option, the vegetable diet option, and the combined diet option for three selected organs.

\subsubsection{Dlet Correction Factor and Area Correction Factor Relationship}

In Section 2.1.1, one method for adjusting the diet (selection of diet option) of the site intruder was described. The ONSITE/MAXIl computer 
IABLE 2.1-1. Fractional Contribution of Meat and Vegetable Diet to Tota1-Body Dose-Rate Factors During the First Year of Exposure for Selected Radionuclides

\begin{tabular}{|c|c|c|c|c|}
\hline \multirow[b]{2}{*}{ Radionuclide } & \multicolumn{2}{|c|}{ Leaf Mechanism } & \multicolumn{2}{|c|}{ Sol] Mechanism } \\
\hline & $\begin{array}{l}\text { Meat } \\
\text { Diet }\end{array}$ & $\begin{array}{l}\text { Vegetable } \\
\text { Diet } \\
\end{array}$ & $\begin{array}{l}\text { Meat } \\
\text { Dfet }\end{array}$ & $\begin{array}{l}\text { Vegetable } \\
\text { Diet }\end{array}$ \\
\hline $3_{H}$ & 0.7 & 0.3 & 0.3 & 0.7 \\
\hline${ }^{14} \mathrm{C}$ & 0.8 & 0.2 & 0.4 & 0.6 \\
\hline${ }^{60} \mathrm{Co}$ & 0.1 & 0.9 & 0.3 & 0.7 \\
\hline${ }^{90} \mathrm{~S} r+D^{(a)}$ & 0.3 & 0.7 & 0.1 & 0.9 \\
\hline${ }^{137} \mathrm{Cs}+\mathrm{D}$ & 0.7 & 0.3 & 0.4 & 0.6 \\
\hline $238_{U+D}$ & 0.2 & 0.8 & 0.1 & 0.9 \\
\hline
\end{tabular}

(a) tD means $p l u s$ short-lived radfoactive decay products.

IABLE 2.1-2. Results of Sample Problem Three for the Three Land-Use Diet Options

\begin{tabular}{|c|c|c|c|c|c|}
\hline Organ & $\begin{array}{c}\text { Diet } \\
\text { Option } \\
\end{array}$ & $\begin{array}{l}\text { Total Dose } \\
\text { (rem) } \\
\end{array}$ & $\begin{array}{l}\text { Dominant } \\
\text { Pathway }\end{array}$ & $\begin{array}{l}\text { Dominant } \\
\text { Radionuc] jode }\end{array}$ & $\begin{array}{c}\text { Maximum } \\
\text { Year }\end{array}$ \\
\hline Tota T-Body & $\begin{array}{l}\text { Meat } \\
\text { Vegetable } \\
\text { Combined }\end{array}$ & $\begin{array}{l}1.8+1 \text { (b) } \\
1.8+1 \\
2.2+1\end{array}$ & $\begin{array}{l}\text { External } \\
\text { Ingestion } \\
\text { External }\end{array}$ & $\begin{array}{l}60 \mathrm{Co} \\
90 \mathrm{Sr+D} \\
60^{\mathrm{Co}}\end{array}$ & $\begin{array}{l}10 \\
22 \\
10\end{array}$ \\
\hline Bone & $\begin{array}{l}\text { Meat } \\
\text { Vegetabie } \\
\text { Combined }\end{array}$ & $\begin{array}{l}1.9+1 \\
5 \cdot 3+1 \\
5.6+1\end{array}$ & $\begin{array}{l}\text { External } \\
\text { Ingestion } \\
\text { Ingestion }\end{array}$ & $\begin{array}{l}{ }^{60} \mathrm{Co} \\
90 \mathrm{Sr+D} \\
90 \mathrm{Sr+D}\end{array}$ & $\begin{array}{l}10 \\
27 \\
27\end{array}$ \\
\hline $\begin{array}{l}\text { Lower } \\
\text { Large } \\
\text { Intestine } \\
\text { of GI- } \\
\text { Tract }\end{array}$ & $\begin{array}{l}\text { Meat } \\
\text { Vegetable } \\
\text { Combined }\end{array}$ & $\begin{array}{l}1.3+1 \\
1.6+1 \\
1.7+1\end{array}$ & $\begin{array}{l}\text { External } \\
\text { External } \\
\text { External }\end{array}$ & $\begin{array}{l}60 \mathrm{Co} \\
60 \mathrm{Co} \\
60 \mathrm{Co}\end{array}$ & $\begin{array}{l}10 \\
10 \\
10\end{array}$ \\
\hline
\end{tabular}

(a) Napier et al. (1984), Section 3.4.3.

(b) Where $1.8+1$ indicates $1.8 \times 10^{1}$. 
programs contain two additional methods for adjusting the diet of the intruder. One method indicates the size of the waste disposal site in fractional hectares. Based on the indicated site size, an area correction factor is applied as discussed in Napier et a 1. (1984, Section 2.1.4.1). The second method directiy indicates the portion of the intruder's diet that is grown on the waste disposal site (referred to as diet correction factor). These three methods al low substantial flexibility in scenarfo construction when considering the agricultural pathways. However, it is important for the user to understand the relationships among these three methods so they can be properly applied.

The area correction factor and the diet correction factor are both muitipljers that modify the intruder's selected diet. Minor changes have been made to the ONSITE computer program to ensure that the user cannot inadvertently apply both a diet correction factor and an area correction factor. The order of questions during the input process has been rearranged so the question concerning the area correction factor is presented before the query about the dfet correction factor. If the user selects a waste disposal site size of less than a hectare, indicating that an area correction factor is to be applied, the option to apply a diet correction factor is bypassed. Computer implementation of these modiffcations is discussed in Section 2.2.1.

\subsubsection{Resuspension and Inhalatjen Area Correction Factor}

The original documentation of the ONSITE/MAXIl computer program (Napier et a 1. 1984) accounted for sites of 11 mited size. The document developed and discussed area correction factors that were intended to reduce the default exposure pathway conditions to account for sites with areas less than 1 ha. These factors applied to the direct exposure pathway and the combined ingestion and inhalation pathways. A sensitivity study was used for developing the direct exposure pathway area correction factors. A step function area correction factor relationship was assumed for both ingestion and inhalation (as shown in Figures 2.1-1 and 2.1-4 of Napier et a1. 1984). After careful consideration of the potential magnitude of the area correction for inhalation factors, it was determined that the area correction developed for the direct exposure pathway should be applied for the inhalation pathway, instead of the assumed step function used for ingestion. This is because many of the experiments relating air and soll concentrations were performed on sites of 7 imited size (i.e., sites with areas of I ha or 1ess) (Sehmel 1974; Milham et al. 1976; Sehmel and Lloyd 1976). Thus, it is perhaps not unreasonable to assume that the area correction factor would approach 1.0 for a relatively small site $(0.1$ to 0.2 ha). The revised area correction factors for direct exposure and inhal ation are shown in Figure 2.1-1 and the area correction factors used for ingestion are shown in Figure 2.1-2. The computer implementation of these modifications is discussed in Section 2.2.4. 


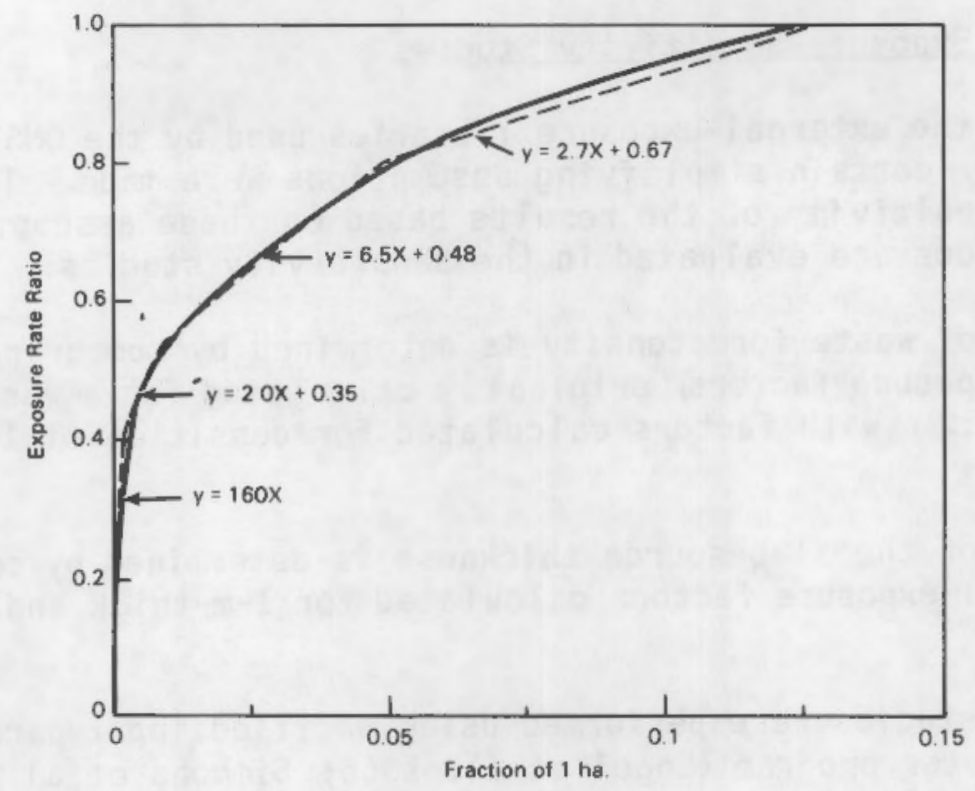

FIGURE 2.1-1. Area Correction Factors for the External Exposure and Inhalation Pathways

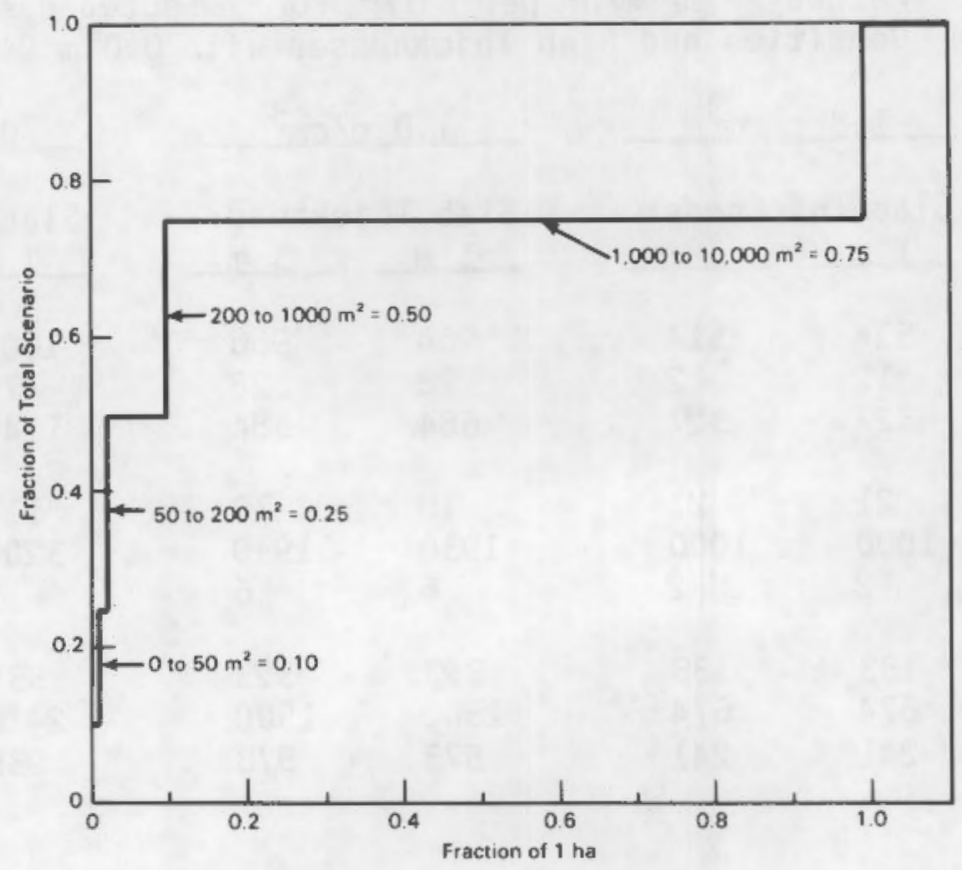

FIGURE 2.1-2. Area Correction Factors for the Ingestion Pathway 


\subsubsection{External Exposure Sensitivity Studies}

When developing the external-exposure libraries used by the ONSITE/MAXIl computer program, certain simplifying assumptions were made. This section discusses the sensitivity of the results based on these assumptions. Two primary assumptions are evaluated in the sensitivity studies:

- The effect of waste form density is determined by comparing the external-exposure factors, originally calculated for a waste form density $\mathrm{g}$ f 1.8, with factors calculated for densities of 1.0 , and $0.6 \mathrm{~g} / \mathrm{cm}^{3}$.

- The effect of the slab-source thickness is determined by comparing the external-exposure factors calculated for 1-m-thick and 3-m-thick slabs.

The sensitivity studies were performed using modified input parameters with the ISOSHLD computer program (Engel et a 1. 1966; Simmons et a 1. 1967). A summary of the results generated is shown in Table 2.1-3 for selected radionuclides based on a constant source strength of $1 \mathrm{ci} / \mathrm{m}^{3}$ of each radionuclide. These results show there is a strong dependence on waste form density; that is, for a constant source strength, the less the waste density, the greater the calculated dose rate. However, for each waste density there is little dependence on slab thickness.

IABLE 2.1-3. Sensitivity Study Results for the External Exposure Pathway - mrem/hr per $\mathrm{Ci} / \mathrm{m}^{3}$ for Selected Waste Form Densities and Slab Thicknesses with $0.0 \mathrm{~m}$ Overburden

\begin{tabular}{|c|c|c|c|c|c|c|}
\hline \multirow[b]{3}{*}{ Radionuclide } & \multicolumn{2}{|c|}{$1.8 \mathrm{~g} / \mathrm{cm}^{3}$} & \multicolumn{2}{|c|}{$-1.0 \mathrm{~g} / \mathrm{cm}^{3}$} & \multicolumn{2}{|c|}{$0.6 \mathrm{~g} / \mathrm{cm}^{3}$} \\
\hline & \multicolumn{2}{|c|}{ S1ab Thickness: } & \multicolumn{2}{|c|}{ STab Thickness: } & \multicolumn{2}{|c|}{ Slab Thickness: } \\
\hline & $1 \mathrm{~m}$ & $3 \mathrm{~m}$ & 1m & 3. $\mathrm{m}$ & $1 \mathrm{~m}$ & $3 \mathrm{~m}$ \\
\hline $\begin{array}{l}{ }^{22} \mathrm{Na} \\
{ }^{51} \mathrm{Cr} \\
{ }^{54} \mathrm{Mn}\end{array}$ & $\begin{array}{r}514 \\
12 \\
327\end{array}$ & $\begin{array}{r}514 \\
12 \\
327\end{array}$ & $\begin{array}{r}964 \\
28 \\
684\end{array}$ & $\begin{array}{r}966 \\
28 \\
684\end{array}$ & $\begin{array}{r}1600 \\
470 \\
1140\end{array}$ & $\begin{array}{r}1630 \\
471 \\
1150\end{array}$ \\
\hline $\begin{array}{r}{ }^{57} \mathrm{Co} \\
60_{\mathrm{Co}} \\
90_{\mathrm{Sr}+\mathrm{D}}\end{array}$ & $\begin{array}{r}21 \\
1000 \\
2\end{array}$ & $\begin{array}{r}21 \\
1000 \\
2\end{array}$ & $\begin{array}{r}70 \\
1930 \\
6\end{array}$ & $\begin{array}{r}70 \\
1930 \\
6\end{array}$ & $\begin{array}{r}117 \\
3200 \\
9\end{array}$ & $\begin{array}{r}117 \\
3270 \\
9\end{array}$ \\
\hline $\begin{array}{l}{ }^{131} I_{I} \\
134 C_{s} \\
137 C_{s+0}\end{array}$ & $\begin{array}{l}133 \\
674 \\
241\end{array}$ & $\begin{array}{l}133 \\
674 \\
241\end{array}$ & $\begin{array}{r}323 \\
1500 \\
573\end{array}$ & $\begin{array}{r}323 \\
1500 \\
573\end{array}$ & $\begin{array}{r}539 \\
2470 \\
935\end{array}$ & $\begin{array}{r}541 \\
2500 \\
942\end{array}$ \\
\hline
\end{tabular}


Based on this result, the ONSITE/MAXIl computer program has been modifled to permit the user to select the waste form density when performing external-exposure calculatigns. The possible waste form densities that the user may select are $1.8 \mathrm{~g} / \mathrm{cm}^{3}$ (the approximate density of 5011 ), $1.0 \mathrm{~g} / \mathrm{cm}^{3}$ (the density of water), or $0.6 \mathrm{~g} / \mathrm{cm}^{3}$ (the approximate density of noncompacted trash waste forms). No corrections for slab thickness are included in the externa 1-exposure data 7 ibraries.

\subsubsection{Stored Waste Scenarie Description}

As stated in Section 2.1, the Stored Waste Scenario is a sub-set of the External-Exposure Scenario in which the user selects the stored waste doseconversion factor files instead of the surface or burled waste files. Including this scenario permits the user to consider cases were wastes are disposed of in a storage bullding, vault, or cave, and where an intruder would on ly receive external exposure from penetrating radiation. This type of scenario was first considered in a document on decommissioning by Oak et a 1. (1980). The dose-conversion factor files used to model this case are based on an intruder 1 ocated $3 \mathrm{~m}$ away from a storage area with dimensions of $3 \mathrm{~m}$ high by $10 \mathrm{~m}$ wide by $3 \mathrm{~m}$ deep. Because it is difflcult to anticipate potential variation of stored waste conditions and exposure geometries, dose-conversion factors for only one selected geometry have been developed. However, the user may select the waste density (as described in Section 2.1.4) and exposure duration and develop his own modeling assumptions. The effects of reflected gamma energy from distant wal $1 \mathrm{~s}$ or surfaces in the storage facility are not included because shielding calculations have shown that the dominant contributor to the dose rate will be from "line-of-sight" with the stored wastes (B1 izard 1962). For photon energles greater than about 1 Mev, the incremental contribution from reflected radiation would be about $1 \%$. For 1 ower photon energies, the incremental contribution would be as high as $15 \%$ (Jaeger 1968). Al so, it is impossible to completely model the large potential for variable conditions at real waste storage facilities. A description of the data base containing the optional external-exposure files is included in Section 2.3.4, and an example problem showing the input and output used to run this scenario using ONSITE/MAXIl is given in Section 3.4.

\subsubsection{Comparison of Maximum Annual Dose to Committed Dose Equivalent}

As stated in Napier et a1. (1984), the fundamental relationship for calculating radiation doses to people from any radionuclide exposure pathway is given in Equation (2.1) (Soldat, Robinson, and Baker 1974)

$$
R_{i p r}=C_{i p} U_{p} D_{i p r}
$$


where

$$
\begin{aligned}
& R_{\text {ipr }}=\text { the radiation dose-equivalent or committed radiation dose- } \\
& C_{i p}=\text { concentration of radionuclide, } i \text {, in the media of exposure } \\
& \text { pathway, } \mathrm{p} \text {; }\left(\mathrm{pCi} / \mathrm{m}^{3}, \mathrm{pCi} / \mathrm{L} \text {, or } \mathrm{pCi} / \mathrm{kg}\right) \text { for calculations } \\
& \text { involving afrborne radionuclides, } C_{\text {f }} \text { is replaced with the } \\
& \text { term, } x \text {, which represents the average airborne concentration } \\
& \text { of radionuclide, } 1 \text {. } \\
& \begin{aligned}
U_{p}= & \text { usage parameter (exposure rate or intake rate) associated with } \\
& \text { exposure pathway, } p(\mathrm{hr} / \mathrm{yr}, \mathrm{L} / \mathrm{yr} \text {, or } \mathrm{kg} / \mathrm{yr})
\end{aligned} \\
& D_{i p r}=\text { radiation dose-equivalent factor or the committed dose- } \\
& \text { equivalent factor for radionuclide, } i \text {, exposure pathway, } p \text {, } \\
& \text { and organ, } r \text {, to convert the concentration and usage } \\
& \text { parameters to the radiation dose equivalent or to the } \\
& \text { committed radiation dose equivalent (mrem/pCi) }
\end{aligned}
$$

Analyzing radiation doses from separate exposure pathways requires determining the radionuclide concentrations and exposure rate or intake rate associated with each exposure pathway.

Site-specific parameters can be used to determine the exposure pathways, the radionuclides, and the exposure or intake rates. For external exposure, the concentration of radionuclides and the duration of exposure must be quantified. For ingestion of farm products grown on a contaminated site, the radionuclide concentration in separate food products must be determined by accounting for root uptake from soll, dry deposition from air onto plant surfaces, or animal consumption of contaminated forage or feed. The annual diet for the maximally exposed individual and the holdup time between harvest and consumption must also be determined. For inhalation, the airborne concentration of resuspended radionucl ides can be determined directly from the ground concentration using a mass-loading factor, resuspension factor, or resuspension rate analysis (Anspaugh et al. 1975).

Calculating the annual dose to an organ of reference using the MAXIl computer program requires the dose equivalent from exposure during the year of interest plus the annual dose resulting from previous years of intake. The general expression for annual dose calculations is deduced by inspecting the annual dose equations for the first 3 years of continuous exposure. For the first year, the annual dose to an organ of reference is simply the summation of the radiation dose equivalents from al 1 internal and externalexposure pathways. For the second year, the annual dose is calculated by the following expression (Kennedy et a 1. 1979): 


$$
A_{2}=R_{2}^{*}+\left(R_{1,2}-R_{1,1}\right)
$$

where

$$
\begin{aligned}
A_{2}= & \text { the annual dose to the organ of reference during the second } \\
& \text { year from al } 1 \text { exposure pathways, ren } \\
\mathrm{R}_{2}= & \text { the radiation dose equivalent in the second year to the organ } \\
& \text { of reference from all internal and external-exposure pathways } \\
& \text { from intake and exposure in the second year, mrem } \\
\mathrm{R}_{1,2}= & \text { the committed dose equivalent to the organ of reference for } \\
& \text { the first two years from radionucl ldes internal ly deposited } \\
& \text { during intake from exposure pathways in the first year, mrem } \\
\mathrm{R}_{1,1=} & \text { the radiation dose equivalent to the organ of reference for } \\
& \text { the first year from radionuclides internally deposited during } \\
& \text { intake from exposure pathways in the first year (no external } \\
& \text { component to the dose equivalent), mrem. }
\end{aligned}
$$

The second-year annual dose to an organ of reference [ $A_{2}$ in Equation (2.2)] is the summation of the radiation dose equivalents from al 1 exposure pathways during the second year and the dose equivalent delivered during the second year from the radionuclides internaliy deposited in that organ during the first year. The term in parentheses in Equation (2.2) is the expression for the dose equivalent to the organ of reference from radionuclides deposited in that organ during the first year. It is found by subtracting the first-year dose equivalent, resulting fom internally deposited radionuclides, from the second-year committed dose equivalent. The mathematical expression for the annual dose to an organ of reference in the third year of continuous exposure 1s (Kennedy et a 1. 1979):

$$
A_{3}=R_{3}^{*}+\left(R_{1,3}-R_{1,2}\right)+\left(R_{2,2}-R_{2,1}\right)
$$

where

$A_{3}=$ the annual dose to the organ of reference during the third year from all exposure pathways, mrem

$R_{3}^{*}=$ the radiation dose equivalent in the third year to the organ of reference from all internal and external-exposure pathways from intake and exposure in the third year, mrem.

In Equation (2.3), the terms $R_{3} R_{2}$ and $R$ are simliar in form, each containing two subscripts. the filst subscilipt defines the year of intake or exposure after the start of continuous exposure, and the second defines 
the number of years used in calculating the committed dose equivalent. The quantity in the first parentheses is the dose equivalent to the organ of reference in the third year from radionuclides deposited during the first year of continuous exposure $(1, \theta .$, the difference between the third-year committed dose equivalent and the second-year committed dose equivalent). The quantity in the second parentheses is the dose equivalent in the third year to the organ of reference from radionuclides deposited during the second year of continuous exposure ( $1 . \theta_{.}$. the difference between the secondyear committed dose equivalent and the f1rst-year committed dose equivalent).

The general expression for calculating the annual dose to an organ of reference during any year after the start of continuous exposure is expressed as (Kennedy et a). 1979):

$$
A_{t}=R_{t}^{*}+\sum_{i=1}^{t-1}\left(R_{i,(t-1+1)}-R_{i,(t-1)}\right)
$$

where

$$
\begin{aligned}
A_{t}= & \text { the annual dose during the year, } t \text {, from all exposure pathways } \\
& \text { to the organ of reference, mrem } \\
R_{t}^{*}= & \text { the radiation dose equivalent in year, } t \text {, to the organ of } \\
& \text { reference from all internal and external-exposure pathways from } \\
& \text { intake and exposure in the year, } t \text {, mrem. }
\end{aligned}
$$

The summation term in Equation (2.4) represents the dose equivalent delivered to the organ of reference in year, $t$, from radionuclides deposited in the organ from intake in al1 previous years since the start of continuous exposure. This term is valid only for positive integer values of $t$. For $t$ equal to $l$, the summation term is zero.

The annual dose, $A_{t}$, to the organ of reference is calculated for each value of $t$ from $l$ to 50 , and the maximum annual dose is determined by inspection. Experience with this method to date indicates 50 years as a suitable maximum value of $t$; however, higher maximum values are not precluded. The radiation dose equivalent terms required by Equation (2.4) are determined from Equation (2.1) using existing radiation dose computer programs for pertinent radiation-exposure pathways. Details about calculating the radionuclide concentrations in various media, $C_{10}$, from Equation $(2.1)$, are given in Sections 2.1.4.1 through 2.1.4.5 of Napler et a1. (1984).

The annual dose, $A_{t}$, defined by Equation $(2.4)$, is then compared to the 50year committed dose equivalent. The radiation dose-commitment accounts for the dose received over a specified amount of time from intake during one year of exposure. The common dose commitment period used in most applications is 50 years, to account for the average adult 1 ifetime; however, any 
time period may be used. To provide a simple 11 lustrative comparison, a dose commitment period of 3 years $w 111$ be considered. It should be noted that the same general conclusions reached for the 3 -year commitment al so apply to the 50-year commitment.

As an example, the annual dose in the third year after the start of continuous exposure, based on Equation (2.3), is considered. First, the term $R_{3}$ is replaced with the term $D_{3,3}$. This new term represents the dose equivalent during the third year from al 1 intake and external exposure occurring during the third year. Next, the $\left(\mathrm{R}_{1,3}-\mathrm{R}_{1,2}\right)$ term is replaced with the term $D_{1}, 3$, representing the dose delivered in the third year after intake in the first year; and the $\left(R_{2,2}-R_{2,1}\right)$ term is replaced with the term $D_{2,3}$, representing the dose del fvered ${ }^{\prime}$ the third year after intake in the second year. Equation (2.3), or the expression for the annual dose during the third year, is now expressed as:

$$
A_{3}=D_{3,3}+D_{1,3}+D_{2,3}
$$

where

$$
\begin{aligned}
D_{3,3}= & \text { the dose equivalent during the third year from al } 1 \text { internal and } \\
& \text { external exposure occurring in the third year of continuous } \\
& \text { exposure } \\
D_{1,3}= & \text { the dose equivalent in the third year resulting from intake in } \\
& \text { the first year of continuous exposure } \\
D_{2,3}= & \text { the dose equivalent in the third year resulting from intake in } \\
& \text { the second year of continuous exposure }
\end{aligned}
$$

and where $A_{3}$ is as defined for Equation (2.3).

The dose received during the first 3 years of continuous exposure, at a constant rate of intake by ingestion or inhalation, is graphically represented in Figure 2.1-3. The size of the boxes is used to show the relative dose recelved in any specified year from a particular year of intake. The dose received in the first year is shown as one box, labeled $D_{1,1}$; the dose recelved in the second year is shown as two boxes, 7 abeled $\mathrm{D}_{1,2}$ and $\mathrm{D}_{2,2}$; and the dose received in the third year is shown as three boxes, labeled $D_{1,3}, D_{2,3}$, and $D_{3,3}$. The 3-year dose commltment is the sum of the bottom row of boxes shown in Figure 2.1-2, or $\left(D_{1,1}+D_{1,2}+D_{1,3}\right)$.

For conditions of constant intake over the 3-year perlod, the top row of boxes are of equal size, or $D_{1,1}=D_{2,2}=D_{3,3}$. Because the ef fective half-life of a radionuclide is constant. the dose received in the year following the intake is reduced by a constant amount. This is shown in Figure 2.1-2 as $D_{1,2}=D_{2,3^{\circ}}$. Both the annual dose in the third year and the 3-year dose commitment contain the term $D_{1,3}$. Thus, it can be seen from the sizes of the boxes in Figure 2.1-3, for the condition of constant 
intake, that the annual dose in the third year and the 3-year dose commitment are equal.

In addition, Linde 1 (1985) recently demonstrated the equality between the collectfve dose commitment from one year of intake and exposure and the highest future annual col lect Ive dose under steady-state conditions for a period of continuous exposure at a constant rate. The condition of constant intake is met when the radionuclide of concern has a long physical half-life. For those radionuclides, MAXIl reports the maximum annual dose as occurring in the last year (50th year) of continuous exposure. Thus, for a 50-year exposure sttuation, the maximum annual dose and the 50-year comitted dose equivalent are equal.

For short-lived radionuclides, or those with effective half-lives of a few months or less, essentially all of the dose is received in the first year; thus, the first-year dose equals both the maxtmum annual dose and the 50year committed dose equivalent.

The external-exposure pathway is considered along with inhalation and sometimes ingestion of food products for the scenarios of interest to the assessment of onsite disposal of radioactive wastes. The externa 1-exposure pathway does not result in a dose during subsequent years; that is, the first-year dose and the 50-year commitment are equal for external exposure. Thu5, for radionuclides and/or exposure scenarios dominated by the externalexposure pathway, the maximum annual dose peaks in the first year and equals (or closely approximates) the 50-year dose commitment.

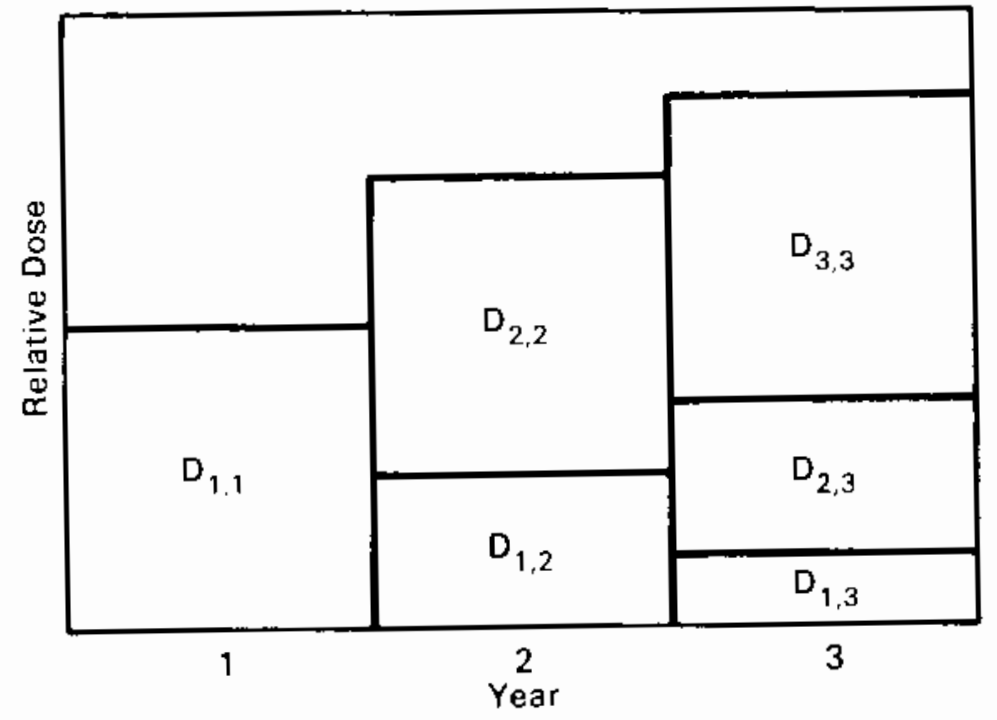

EIGURE 2,I-3. Equality Between the Dose Commitment and the Annual Dose Under Continuous Exposure Conditions of Constant Annual Intake 
Experience with the MAXIl computer program indicates that, for mid-1ived radionuclides (those with half-lives of $1-50$ years) and for scenarios of interest to onsite disposal (which include the external-exposure pathway), the maximum annual dose will approximate the 50-year committed dose equivalent quite closely. The closeness of the comparison w11l depend on the relative contribution of the exposure pathways considered in the scenario analysis.

As an example of the comparison of the maximum annual dose with the 50-year dose comitment, an independent derivation of the 10 CFR Part 61 (NRC 1984) low-level waste disposal limits was performed using the MAXIl computer program (Kennedy and Napier 1984). Major differences in the 50-year dose commitment and the maximum annual dose would result in significant differences in the calculated low-level waste disposal limits. The MAXIl derivation used the intruder construction and intruder agriculture scenarios, as defined in the Draft Environmental Impact Statement (DEIS) in support of 10 CFR Part 61 (NRC 1981).

Disposal 1imits are 11 sted in 10 CFR Part 61 (NRC 1984) for three classes of commercial radioactive wastes: $A, B$, and $C$. $C$ lass $A$ wastes have minimum stability requirements, low levels of radloactivity, and their limits reflect 100 years of radioactive decay that would occur during an institutional control period. $C 1$ ass $B$ wastes permit higher activity levels and must meet more rigorous waste-form requirements to ensure stability after disposa 1. Class $C$ wastes are required to have a stable waste form, a package with higher integrity than required for Class $A$ or $B$ wastes, and their limits reflect 500 years of radioactive decay. Disposed Class $C$ wastes are further assumed to provide ten times more protection from intrum sion than disposed $C 1$ ass $A$ wastes.

The results of the derivation of the $C$ lass $A$ and $C$ lass $C$ disposal 1 imits using the MAXIl computer code, based on maximum annual dose instead of the 50-year dose commitment as used by NRC, are shown in Tabie 2.1-4. By carefulily fol lowing the scenarlo descriptions given in the (NRC 1981) and correctly accounting for radfoactive decay, the results generated by MAXII general1y compare closely to the 10 CFR 61 disposal 1 imits. The comparison is very close for short to mid hà $\mathrm{f}-1 \mathrm{ife}$ radionuclides (i.e., hal f-lives less than 30 years). The notable exceptions to this close agreenght are the disposal 7 imits for ${ }^{99}$ TC and the Class $C$ disposal 1 imit for ${ }^{137} \mathrm{Cs}$ where gyr values are about ten times the 10 CFR 61 values. The difference in the ${ }^{9}$ Tc concentrations a drinking-water scenario, rather than the intruder scenarios, for results from the NRC's use of the 10 CFR 61 value.

The general agreement of MAXIl calculated values with the 10 CFR 61 disposal limits, accounting for minor modeling differences, Indicates the 50-year dose commitment and the maximum annual dose are quite close for most radionuclides. 
IABLE 2.I-4. Comparison of 10 CFR Part 61 and Ca]culated Low-Level Waste Disposal Concentrations

\begin{tabular}{|c|c|c|c|c|}
\hline \multirow[b]{2}{*}{ Radionuclide } & \multicolumn{2}{|c|}{$\begin{array}{l}10 \text { CFR Part } 61 \\
\text { Concentration } \\
\left.(\mathrm{C} / \mathrm{m})^{3}\right)\end{array}$} & \multicolumn{2}{|c|}{$\begin{array}{c}\text { Ca]culated } \\
\text { Concentrątion } \\
\left(\mathrm{C} 1 / \mathrm{m}^{3}\right)\end{array}$} \\
\hline & Class $A$ & Class C & Class $A$ & Class C \\
\hline $\begin{array}{l}{ }^{14} \mathrm{C} \\
60 \mathrm{Co} \\
59_{\mathrm{Ni}}\end{array}$ & $\begin{array}{c}0.8 \\
700 \\
2.2\end{array}$ & $\frac{8}{22}(a)$ & $\begin{array}{l}0.8 \\
400 \\
1\end{array}$ & $\frac{8}{10}(a)$ \\
\hline $\begin{array}{l}{ }^{63} \mathrm{Ni} \\
90_{\mathrm{Sr}+\mathrm{D}} \\
99_{\mathrm{TC}}^{(b)}\end{array}$ & $\begin{array}{l}3.5 \\
0.04 \\
0.3\end{array}$ & $\begin{array}{r}700 \\
7000 \\
3\end{array}$ & $\begin{array}{l}1 \\
0.03 \\
3\end{array}$ & $\begin{array}{r}200 \\
5000 \\
30\end{array}$ \\
\hline $\begin{array}{l}{ }^{137} \mathrm{Cs+D} \\
239_{\mathrm{Pu}}^{(b)}\end{array}$ & $10^{1}(\mathrm{c})$ & $\begin{array}{l}4500 \\
100^{(c)}\end{array}$ & $\begin{array}{c}0,3 \\
30\end{array}$ & $\begin{array}{r}30000 \\
300\end{array}$ \\
\hline
\end{tabular}

(a) Dashes indicate that no Class $C$ limits are established (i.e., the concentration is 1 imited only by practical considerations including the stability of the waste form, internal heat generation, and handling).

(b) $+D$ means plus short-lived daughters.

(c) Units for ${ }^{239} \mathrm{Pu}$ are in $\mathrm{nCl} / \mathrm{g}$.

\subsubsection{MAXII Iime Line}

To fully understand the scenario construction flexibility of the ONSITE/ MAXIl computer software package, the user must understand the relationships between the times the scenario events are assumed to occur. Figure 2.1-4 contains the "MAXIl time line" and is shown in order to graphically relate: 1) the time at which the radionuclide inventory is disposed of at the site, 2) the optional period of radionuclide decay before the beginning of the intruder scenario, 3 ) the optional period when bujld-up of radionuclides may occur due to irrigation wth contaminated water, and 4 ) the beginning of the intruder scenario which is also the beginning of the dose calculation period. In Figure 2.1-4, the inventory is assumed to be disposed of at the site at time 0 . The intruder scenario and the dose calculation period begin at time ITl, as discussed in Napier et a1. (1984). The intruder scenario and dose calculation period ends at time IT2, always $(I T l+50)$. If ITl is greater than 0 , there will be ITl years of radionuclide decay before the intruder scenario begins. In addition, (ITl $-\mathrm{m}$ ) is the length of time that radionuclides may build up via irrigation before the dose calculation period begins. The MAXII parameter IRR is equivalent to the period (ITl $-m$ ). The MAXIl control parameters that the user may manjpulate are IT1, IT2, and IRR. 
Optional Inventory Decay Period
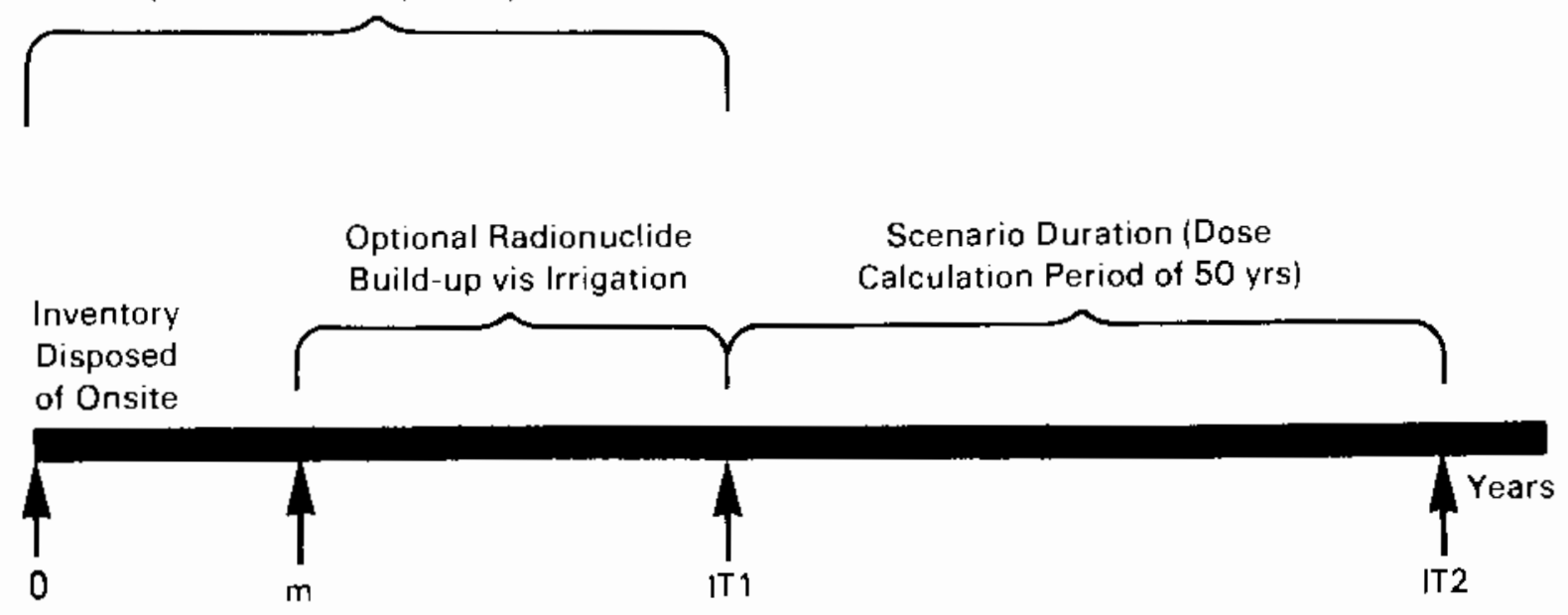

FIGURE 2.1-4. MAXIl Time Line

\subsubsection{Derivation of Area Correction Factors for Ingestion Pathway}

The total diet of a "maximum individual", taken from Napier (1981) is used to construct the step function of Figure 2.1-2. The step function allows consideration of area-intensive practices for small areas without forcing extreme conservatism on larger areas.

A small area is assumed to be intensely farmed for vegetables. An area of about $50 \mathrm{~m}^{2}$ is required for an individual to grow a year's supply of leafy and other aboveground vegetables. An additional area of about $150 \mathrm{~m}^{2}$ is required to grow a year's supply of root vegetables and grains. Larger areas are required for orchards. About 800 to $1800 \mathrm{~m}^{2}$ is required to grow a year's supply of food for a single pig. An area greater than 1 ha is required to support one milk cow.

The percentage of the total diet that each of these foods supplies is also derived from Napier (1981). The above-ground vegetables comprise about 5 to $10 \%$ of the total intake. Grains and root vegetables make up about $15 \%$. Fruit comprises about $30 \%$ and beef and milk products about $25 \%$. These percentages, combined with the areas required for their production, provide the step function curve shown in Figure 2.1-2.

The combination of dietary components is based on a logical progression of garden size versus production. Small areas are assumed to be intensely cultivated for garden vegetables. As the plot size increases, other foods are added. A small orchard and domestic animals are assumed, in addition, as plot size allows. Cattle are only assumed for areas large enough to support them. The step function is used to connect the points rather than a curve. This allows for more efficlent agricultural practices and partial dietary contributions of the various crops. Because the true productionversus-area curve would connect the lower points, the step function is a conservative upper bound. 


\subsection{COMPUTER IMPLEMENTAIION OF SCENARIO AND MODEL ENHANCEMENTS}

The ONSITE/MAXIl model enhancements described in the previous section have been implemented in the computer software package. The following sections contain detalled descriptions of the software changes and are intended to supplement the original ONSITE/MAXIl document (Napier et a1. 1984).

\subsubsection{Expanded Land-Use And Diet Modification Options}

As discussed in Section 2.1.1, the ONSITE/MAXIl software has been modified to include three optional diets for the intruder: 1) the combined diet, 2) the vegetable diet, and 3 ) the meat diet. These diet options are based on the diet listed in Regulatory Gulde 1.109 (NRC 1977). Figure 2.2-1 contains the ONSITE input screen that permits the user to select the intruder's diet. Based on the user's response to this input screen, the ONSITE program automatically assigns the appropriate dose-rate factor files.

The R.G. 1.109 diet raised onsfte may be either:

$$
\begin{array}{ll}
1 \text { - Total diet } & \text { (plant and animal products) } \\
2 \text { - Vegetable product diet } & \text { (plant only) } \\
3 \text { - Antmal product diet } & \text { (mllk, eggs, and meat onjy) }
\end{array}
$$

The default selection is 1 .

Do you wish to change this value $(N / Y)$ ?

EIGURE2.2-I. Example of the ONSITE Diet Option Input Screen

\subsubsection{Waste Density Options for External Exposure}

As described in Section 2.1.4, a study was conducted to determine the sensitivity of the external-exposure doses to the assumptions used in generating the dose-conversion factor files. The results of the sensitivity study indicated that results were strongly dependent on the density of the disposed waste. As a result, the ONSITE/MAXIl software package was modifled to permit the user to select external dose-rate factors that correspond to one of three optional waste densities. Figure 2.2-2 displays the question asked of the user by the ONSITE computer program. Throe files of external-exposure dose-rate factors, corresponding to the waste densities of $1.8,1.0$, and $0.6 \mathrm{~g} / \mathrm{cm}^{3}$, have been generated for each waste $10 \mathrm{ca-}$ tion option. Based on the user's response to the question in Figure 2.2-2, the ONSITE program $w 111$ automaticaliy assign the appropriate externalexposure dose-rate factor files. 
The waste density may be efther:

$$
\begin{aligned}
& 1-1.8 \mathrm{~g} / \mathrm{cu} \mathrm{cm} \text { (soil) } \\
& 2-1.0 \mathrm{~g} / \mathrm{cu} \mathrm{cm} \mathrm{(water)} \\
& 3-0.6 \mathrm{~g} / \mathrm{cu} \mathrm{cm} \text { (0.5 water }+0.1 \text { carbon) }
\end{aligned}
$$

The defautt selection is 1 .

Do you wish to change this value $(N / Y)$ ?

EIGURE 2.2-2. Example of the ONSITE Waste Density Option Input Screen

\subsubsection{Incidental Surface Contamination for Externa]. Exposure and Inhal ation Pathways}

An additional waste configuration has been added to al 1 ow the user to simulate the external-exposure conditions resulting from incidental surface contamination. External dose-rate factors for an infinite plane of contamination on the sol 1 surface, $15 \mathrm{~cm}$ thick, have been made avallable to the ONSITE user. Previously, these external dose-rate factors were used for agricultural scenarios. However, the user could not explicitiy assign the file containing these dose-rate factors. Figure 2.2-3 depicts the ONSITE program input screen that permits the user to select the $15-\mathrm{cm}$ surface-soll files that can be used with area correction factors to model incidental surface contamination situations. To simulate an incidental surface contamination, the user selects Item 1, "On surface (15 cm thick)" from the menu. The waste location screen contains additional word changes that clarify the available waste configurations.

In this scenario, waste location and depth may be:

$$
\begin{array}{ll}
1 \text { - On surface } & (15 \mathrm{~cm} \text { thick }) \\
2 \text { - On surface } & (1 \mathrm{~m} \text { thick }) \\
3 \text { - Overburden of } 0.5 \mathrm{~m} & (1 \mathrm{~m} \text { thick }) \\
4 \text { - Overburden of } 1.0 \mathrm{~m} & (1 \mathrm{~m} \text { th } f \mathrm{ck}) \\
5 \text { - Stored waste } & (1 \mathrm{~m} \text { thick })
\end{array}
$$

See Table 2.3-1 of NUREG/CR-3620 Supplement. The curront selection is: 2

Do you wish to change this value $(N / Y)$ ?

FIGURE 2.2-3. Example of the ONSITE External Exposure Option Input Screen 


\subsubsection{Inhalation Area Correction Factor}

The modified area correction factor for inhalation used by the ONSITE/MAXII computer software package is discussed in Section 2.13. The computer program was modified to consider the same area correction factor for both the direct exposure and inhalation pathways. Figure 2.1-1 shows this area correction factor relationship between site size and external-exposure rate. As shown in the figure, we have approximated this curve in the ONSITE computer program as the sum of four line segments. This modification is automaticaliy activated when the user identifies a site area of loss than 1 ha.

\subsection{DATA BASE EXPANSION}

Additional files of 1 eaf mechanism, soll mechanism, and external-exposure dose-rate factors were developed to expand the capabilities of the ONSITE/MAXII computer programs. These enhancements to the ONSITE/MAXII data base are part of the modifications described in this supplementary document and are described in the following sections.

\subsubsection{Leaf Mechanism Dose-Rate Factors}

Three files are now provided that contain "environment"-specific leaf mechanism dose-rate factors. These factors are based on 1 pCf of each radionuclide per cubic meter of air. The user can provide any concentration of radionuclides in air as input to the ONSITE program The file names and their descriptions are as follows:

\footnotetext{
VEG20 - Vegetabie diet option consisting of fruit, vegetables and grains grown on the disposal site

MEAT20 - Meat diet option consisting of meat and dalry products obtained from livestock grazed on the disposal site

FILE20 - Combined diet option consisting of fruit, vegetables, grains, and meat and dairy products raised on the disposal stte
}

The ONSITE computer program assigns one of these files to logical unit 20 based on the user's answer to the question shown in Figure 2.2-1. The file format is described in Napler et a1. (1984, Section 2.3.2). An updated version of FILE20 (dated 4/85) is included in the software package.

\subsubsection{Soj]_Mechanism Dose-Rate Factors}

The ONSITE/MAXIl user may select from three optional files containing "environment"-specific soll mechanism dose-rate factors that are based on $1 \mathrm{pCi}$ of radionuclide per cubic meter in air. The file names and their descriptions are as follows: 
VEG21 - Vegetable diet option consisting of fruit, vegetables, and grains grown on the disposal site

MEAT2l - Meat diet consisting of meat and dalry products obtained from 1 ivestock grazed on the disposa 1 site

FILE21 - Combined diet option consisting of fruits, vegetables, grains, and meat and dairy products raised on the disposal site

The ONSITE computer program assigns one of these files to logical unit 21 based on user's answer to the question shown in Figure 2.2-1. The file format is described in Napier et a1. (1984, Section 2.3.3). An updated version of FILE2l (dated 4/85) is included in the software package.

\subsubsection{External-Exposure Mechanism_Dose-Rate Factors}

The ONSITE/MAXIl data base includes 15 files containing external-exposure dose-rate factors for $1 \mathrm{pC} i$ of radionuclide per cubic meter in air. These factors relate the radionuclide source strength to the dose rate in tissue $1 \mathrm{~m}$ away. The file names, $\log \{\mathrm{cal}$ unit assignments, waste density, and descriptions are summarized in Table 2.3-1. The format of these files are described in Napier et a 1. (1984, Sections 2.3.4 and 2.3.8). Listings of the external-exposure dose-rate files are in Appendix $\mathrm{C}$.

The external-exposure dose-rate factors were created by the ISOSHLD (Engel, Greenborg and Hendrickson 1966; Simmons et a 1. 1967) computer program. Tab 1e 2.3-2 summarizes the ISOSHLD parameter values used to approximate each waste configuration. To reduce errors, an automated process was used to generate the external-exposure dose-rate factor files. This process consisted of the following:

- a standardized ISOSHLD input file

- a modified version of the ISOSHLD computer program that produces dose-rate factors to a formatted computer file

- a utility computer program that reads the ISOSHLD-generated file, adds daughter factors to parent when necessary, and writes a MAXI1formatted file.

Files listed in Table 2.3-1 replace the files named PLANSOURC, ROOM, VDLSOURC, BURIEDHF, and BURIED1.

As noted in Table 2.3-1, external-exposure dose-rate factor files may be assigned to either logical unit 22 or 27 . Files assigned to logical units 22 and 27 perform essentially the same functions. Historically, input to FILE22 was defined as dose factors with units of rem/yr per $\mathrm{pCl} / \mathrm{m}^{2}$, while input to FILE27, assumed to be generated by ISOSHLD, was defined in terms 
of $\mathrm{mrem} / \mathrm{yr}$ per $\mathrm{pCi} / \mathrm{m}^{3}$. The MAXIl code operates internally in soil concentration units of $\mathrm{pCl} / \mathrm{m}^{2}$, defined by the root and leaf pathway factors from MAXI2 (FOOD). Whenever the external doses are calculated, the soll concentration units are converted to be compatible with the dose factors. File assignments to 7 gical units 22 and 27 are maintained in the present verstons of MAXIl to al Iow simultaneous consideration of two distinct source geometries (e.g., surface and burfed soll, contaminated soll and a point source, etc.).

\section{IABLE 2.3-1. Dose-Rate Factor Files for External Exposure}

\begin{tabular}{|c|c|c|c|}
\hline Etle Name & $\begin{array}{l}\text { Logical } \\
\text { Unit } \\
\text { Assignment }\end{array}$ & $\begin{array}{l}\text { Waste } \\
\text { Density } \\
\left.\text { (gm/ } \mathrm{cm}^{3}\right)\end{array}$ & Description \\
\hline PLANEA & 22 & 1.8 & \multirow{3}{*}{$\begin{array}{l}\text { Infinite plane of soi } 1 \\
\text { contamination, waste } \\
\text { thickness of } 15 \mathrm{~cm}\end{array}$} \\
\hline PLANEB & 22 & 1.0 & \\
\hline PLANEC & 22 & 0.6 & \\
\hline VOLSOURCA & 27 & 1.8 & \multirow{3}{*}{$\begin{array}{l}\text { Infinite surface slab } \\
\text { source, waste extends } \\
\text { to a depth of } 1.0 \mathrm{~m}\end{array}$} \\
\hline VOLSOURCB & 27 & 1.0 & \\
\hline VOLSOURCC & 27 & 0.6 & \\
\hline BURIEDHFA & 27 & 1.8 & \multirow{3}{*}{$\begin{array}{l}\text { Infinite slab source, } \\
\text { buried in soil wth an } \\
\text { overburden depth of } 0.5 \mathrm{~m} \text {, } \\
\text { waste thickness of } 1.0 \mathrm{~m}\end{array}$} \\
\hline BURIEOHFB & 27 & 1.0 & \\
\hline BURIEDHFC & 27 & 0.6 & \\
\hline BURIEDIA & 27 & 1.8 & \multirow{3}{*}{$\begin{array}{l}\text { Infinite slab source, } \\
\text { buried in soil with an } \\
\text { overburden depth of } 1.0 \mathrm{~m} \text {, } \\
\text { waste thickness of } 1.0 \mathrm{~m}\end{array}$} \\
\hline BURIEDIB & 27 & 1.0 & \\
\hline BURIEDIC & 27 & 0.6 & \\
\hline STOREDA & 27 & 1.8 & \multirow{3}{*}{$\begin{array}{l}\text { Rectangular s1ab source, } \\
10.0 \mathrm{~m} \times 3.0 \mathrm{~m} \text {, waste } \\
\text { thickness of } 1.0 \mathrm{~m}\end{array}$} \\
\hline STOREDB & 27 & 1.0 & \\
\hline STOREDC & 27 & 0.6 & \\
\hline
\end{tabular}


TABLE 2.3-2. ISOSHLD Parameter Values Used for External Dose-Rate Factors

S]ab Source

\begin{tabular}{|c|c|c|c|c|c|}
\hline ISOSHLD Parameter & $\begin{array}{l}\text { Plane Source } \\
\text { At Surface }\end{array}$ & At Surface & $\begin{array}{c}0.5 \mathrm{~m} \\
\text { Overburden }\end{array}$ & $\begin{array}{c}1.0 \mathrm{~m} \\
\text { Qverburden }\end{array}$ & $\begin{array}{c}\text { Stored } \\
\text { Waste. }\end{array}$ \\
\hline IGEOM & 5 & 5 & 5 & 5 & 10 \\
\hline ANGL (degrees) & 90.0 & 90.0 & 90.0 & 90.0 & 90.0 \\
\hline$x(\mathrm{~cm})$ & 115.0 & 200.0 & 250.0 & 300.0 & 400.0 \\
\hline$Y(\mathrm{~cm})$ & & & & & 300.0 \\
\hline$S L T H(\mathrm{~cm})$ & & & & & 1000.0 \\
\hline NSHLD & 3 & 3 & 4 & 4 & 3 \\
\hline $\begin{array}{l}\text { SHIELD } 1: \\
\text { T(1) }(\mathrm{cm}) \\
\text { Material } \\
\text { Dens1ty }\left(\mathrm{g} / \mathrm{cm}^{3}\right)\end{array}$ & $\begin{array}{l}15.0 \\
\text { (a) } \\
\text { (a) }\end{array}$ & $\begin{array}{l}100.0 \\
(a) \\
(a)\end{array}$ & $\begin{array}{c}100.0 \\
(\mathbf{a}) \\
\text { (a) }\end{array}$ & $\begin{array}{l}100.0 \\
(\mathrm{a}) \\
\text { (a) }\end{array}$ & $\begin{array}{l}100.0 \\
\text { (a) } \\
\text { (a) }\end{array}$ \\
\hline $\begin{array}{l}\text { SHIELD 2: } \\
\text { T(2) (cm) } \\
\text { Matertal } \\
\text { Density }\end{array}$ & $\begin{array}{l}95.0 \\
\text { a1r } \\
0.00129\end{array}$ & $\begin{array}{l}95.0 \\
\text { air } \\
0.00129\end{array}$ & $\begin{array}{l}50.0 \\
\text { concrete } \\
\quad 1.8\end{array}$ & $\begin{array}{l}100.0 \\
\text { concrete }(b) \\
\quad 1.8\end{array}$ & $\begin{array}{l}295.0 \\
\text { afr } \\
0.00129\end{array}$ \\
\hline $\begin{array}{l}\text { SHIELD } 3: \\
\text { T(3) (cm) } \\
\text { Material } \\
\text { Density }\end{array}$ & $\begin{array}{r}5.0 \\
\text { skin } \\
1.0\end{array}$ & $\begin{array}{r}5.0 \\
\text { skin } \\
1.0\end{array}$ & $\begin{array}{l}95.0 \\
\text { a1r } \\
1.00129\end{array}$ & $\begin{array}{l}95.0 \\
\text { air } \\
0.00129\end{array}$ & $\begin{array}{r}5.0 \\
\text { skin } \\
1.0\end{array}$ \\
\hline $\begin{array}{l}\text { SHIELD } 4: \\
\text { T(4) }(\mathrm{cm}) \\
\text { Material } \\
\text { Density }\end{array}$ & & & $\begin{array}{r}5.0 \\
\text { skin } \\
1.0\end{array}$ & $\begin{array}{r}5.0 \\
\text { skin } \\
1.0\end{array}$ & \\
\hline WEIGHT (C1) & $1.0 \times 10^{-6}$ & $1.0 \times 10^{-6}$ & $1.0 \times 10^{-6}$ & $1.0 \times 10^{-6}$ & 30.0 \\
\hline NTHETA & & & & & 6 \\
\hline NPSI & & & & & 5 \\
\hline DELR & & & & & 0.2 \\
\hline
\end{tabular}

(a) External doşe-rate factors were generated for the following waste densities:

1) $1.8 \mathrm{~g} / \mathrm{cm}_{3}^{3}$ (material: concrete)

2) $1.0 \mathrm{~g} / \mathrm{cm}^{3}$ (material : water)

(b) The electronic density of soll is approximated by that of concrete. 


\section{REFERENCES}

Anspaugh, L. R., J. H. Shinn, P. L. Phelps and N. C. Kennedy. 1975. "Resuspension and Redistribution of Plutonium in SolTs." Health Phys. $29: 571-582$.

B1 fzard, E. P. (ed). 1962. Reactor Handbook-Volume IIf Part B, Shielding. U. S. Atomic Energy Commission, Interscience Publishers, New York, New York.

Enge1, R. L., J. Greenborg and M. M. Hendrickson. 1966. ISOSHLD - A Computer Code for General Purpese Isotope Shielding Analysis. BNWL-Z36, Pacific Northwest Laboratory, Richland, Washington.

Jaeger, R. G. (ed). 1968. Engineering Compendium on Radiation Shielding. International Atomic Energy Agency, Vienna, Austria.

Kennedy, W. E., Jr., E. C. Watson, G. R. Hoenes and B. A. Napier. 1979. "A Method for Determining Acceptable Residual Radioactive Contamination Leve15." Paper presented at the 24th Annual Meeting of the Health Physics Society, July 8-13, 1979, Philadelphta, Pennsylvania.

Kennedy, W. E., Jr., and B. A. Napier. 1984. "An Independent Derivation of the 10 CFR Part 61 Commerc1al Low-Level Waste Disposa 1 Limits." Paper presented at the 1984 Annual Meeting of the American Nuclear Soclety, June 1984, New Orleans, Louisiana. PNL-SA-11983. Paciflc Northwest Laboratory, Richland, Washington.

Linde1 1, B. 1985. Concepts of Collectjve Dose in Radiological Protection. Nuclear Energy Agency of the Organization for Economic Cooperation and Development, Paris, France.

Milham, R. C., J. F. Schubert, J. R, Watts, A. L. Boni, and J. C. Corey. 1974. "Measured PTutonium Resuspension and Resulting Dose from Agricultural Operations on an 01d Field at the Savannah River Plant in the Southeastern United States." In Proceedings of an IAEA USERDA Symposium on Transuranium Nuclides in the Environment. E. I. du Pont de Nemours \& Co., Afken, South Carolina.

Napier, B. A. 1981. Standardized Input for Hanford Environmental Impact Statements - Part I. PNL-3509, Part 1, Pacific Northwest Laboratory, Rich 1 and, Washington.

Napler, B. A., R. A. Peloquin, W. E. Kennedy, Jr., and S. M. Neuder. 1984. Intruder Dose Pathway Analysis for the Onsite Disposal of Radioactive Wastes: The ONSITE/MAXIl Computer Program. NUREG/CR-3620, U.S. Nuclear Regulatory Commission, Washington, D.C. 
NRC. 1977. Calculation of Annua] Doses to Man From Routine Releases of Reactor Effluents for the Purpose of Evaluating Compliance with 10 CFR Part 50, Appendix I. Regulatory Guide 1.109, Rev. 1, U.S. Nuclear Regu1 atory Commission, Washington, D.C.

NRC. 1981. Draft Environmental Impact Statement on 10 CFR Part 612 "Licensing Requirements for Land Disposal of Radieact ive Waste." NUREG-0782, U.S. Nuclear Regulatory Commission, Washington, D.C.

NRC. 1982. Einal Environmental Impact Statement on 10 CFR Part $6 l_{2}$ "Licensing Requirements for Land Disposal of Radieactive Waste." NUREG-0945, U.S. Nuclear Regulatory Comission, Washington, D.C.

NRC. 1984. Licensing Requirements for Land Disposal of Radioactive Waste. Title 10, Part 6l. U.S. Nuclear Regulatory Commission, Washington, D.C.

Oak, H. D., G. M. Holter, W. E. Kennedy, Jr., and G. J. Konzek, 1980. Jechnology, Safety and Costs of Decomissioning a Reference Boiling-Water Reactor Power Station. NUREG/CR-0672, Vol s. 1 and 3. U.S. Nuclear Regulatory Comsission, Washington, D.C.

Sehme], G. A. 1974. "Particle Resuspension from an Asphalt Road." In Atmosphere-Surface Exchange of Particulate and Gaseous Pollutants, CONF-740921, Pp. 862-880, Nationa 7 Technical Information Service, Springfield, Virginia.

Sehme 1, G. A, and F. D. Lloyd. 1976. "Resuspension Rates from a Circular Ffeld Source." In Pacific Northwest Annual Report for 1975 to the DOE Assistant Secretary for the Environment, Part 3, Atmospheris Sciences, Pp. 96-98, BNWL-2000, Pacific Northwest Laboratory, Richland, Washington.

Simmons, G. L., J. J. Regimbal, J. Greenborg, E. L. Kel ly, Jr., H. H. Van Tuy 1. 1967. ISOSHLD II Code Revjsion to Include Calculation of Dose Rate from Shielded Bremsstrahlung Seurces. BNWL-236 Supplement I, Pacific Northwest Laboratory, Richland, Washington.

Sol dat, J. K., N. M. Robinson and D. A. Baker. 1974. Models and Computer Codes for Evaluating Environmental Radiation Doses. BNWL-1754, Pacific Northwest Laboratory, Richland, Washington. 



\subsection{PROCEDURES}

The ONSITE/MAXIl software package has been installed on both $\operatorname{CDC}^{(a)} 6600$ 7600 and $V A X(b) 780$ computers, and the ONSITE computer program has also been installed on the IBM $(\mathrm{C})$ PC . The user instructions for the ONSITE/ MAXIl computer software package (Napier et al. 1984) are written for the CDC computer. User instructions for the VAX computer are presented in this section to complete the documentation for both computer systems. This section also contains detailed discussions of selected input parameters, enhanced input features of the ONSITE computer program, and a sample probiem considering the stored waste sub-set of the External Exposure Scenarlo. It should be noted that, except for the system-level commands, the operation of the ONSITE/MAXII computer software is identical on both the $V A X$ and CDC computers, and that full verification and test problems have been completed.

The following conventions are used in this manual to distinguish exact user input from instructions and from computer program displays.

<crs

boldface

CAPITAL LETIERS
- When encountered in the manual, this symbol indicates that the keyboard key labeled RETURN should be pressed. This is analogous to the carriage return for those more familiar with typewriters than computers.

- Boldface print designates information entered at the terminal by the user. NOTE: In the appendices, information entered by the user is underlined.

- When capital letters in boldface type are encountered, the user should type in the boldface letters exactly as shown.

lower-case letters - When lower-case letters are encountered in boldface type, the user should substitute unique identifiers.

\subsection{USER INSTRUCTIONS FOR THE YAX COMPUTER}

Instructions for using the ONSITE/MAXIl software package on a VAX computer are included below. A file named ONSITE. COM must reside in the user's directory. The ONSITE. COM should contain the following commands:

(a) IBM is a registered trademark of International Business Machines Corporation, Boca Raton, Florida.

(b) VAX is a trademark of Digital Equipment Corporation, Nashua, New Hampshire.

(c) IBM is a registered trademark of International Business Machines Corporation, Boca Raton, Florfda. 


\author{
ASSIGN SYS\$COMMAND FORO05 \\ ASSIGN RMDONS.DAT FOROIO \\ ASSIGN MAXII.COM FOR007 \\ RUN ONSITE
}

To execute ONSITE on the VAX computer, type:

\title{
ONSITE 〈Cr>
}

Upon completion of ONSITE, the user may execute MAXIl either interactively or in a batch processing mode. To execute MAXIl interactiveiy, type:

GWXIl <cr>

To submit MAXIl for batch processing with printed output, type:

SLBMIT MAXI <cr>

If the user wishes to edit the MAXIl input flle before execution, type:

EDIT MUII.c0m 〈cr>

To save the MAXIl input file, type:

RENANE MXII.COM newname, ext <cr>

Where "newname.ext" is a user-selected file name.

\subsection{INPUT PARAMETERS - FURTHER DISCUSSION}

This section contains a summary of the default parameter values for the ONSITE waste disposal scenarios, the sample problem parameter values, and comments included to clarify the intended use of selected parameters. Information in this section is not necessary for successfut execution of the ONSITE program. It is included for for reference and to provide a more complete set of documentation. Because of the enhancements documented in this manual, the default parameter values assigned to each scenarlo have been modified as shown in Table 3.2-1. This table is intended to replace Table 3.2-1 of Napier et al. (1984).

The five ONSITE/MAXIl sample problens (Napier et a1. 1984) closely parallel the five onsite disposal scenarios. Consequently, it is easy to confuse sample problen conditions with default onsite disposal scenario default conditions. In order for the user to more easily distinguish between the two, a table of parameter values used in the sample problems is included. Table 3.2-2 gives parameter values for each of the five sample problems documented in Napier et a]. (1984). 


\section{TABLE 3.2-1. Scenario Default Parameter Values}

\section{Pathojays}

External exposure to shab source of vaste (IEXT)

External exposure to an infinite plane of waste (ISUR)

Food consumption (IFOD)

Drinking water consumption (IWAT)

Aquatic food product consumption (IARG)

Af $r$ submersion (IAIR)

Hours of exposure: To external

To Inhalation

Waste oflution factor (SRDIL)

Resuspension Model: Age of contamination (yr) (AGE)

Thtckness of surface soll layer avallable (cm)

Ratio of waste concentration in surface to subsurface soll (RPF I)

Fraction of total roots in top $15 \mathrm{~cm}$ of soll (RFl)

Fraction of total roots in subsurface soll (RF2)

Fraction of diet grown on site (ROF2)

Years of prior irrigation of $s$ te (IRR)

Selected organs (KORG)

No. of years after waste is disposed that: Scenar1o beg1ns (IT1) Scenarto ends (IT2)

Site size (ha) (FRSIZ)
Scenarios

\begin{tabular}{|c|c|c|c|c|}
\hline $\begin{array}{l}\text { External } \\
\text { Exposure }\end{array}$ & $\begin{array}{c}\text { External } \\
\text { Exposure Plus } \\
\text { Inhalat1on }\end{array}$ & Agr\{cultural & $\begin{array}{l}\text { Irrigation/ } \\
\text { Drinking } \\
\text { Water }\end{array}$ & User Deflned \\
\hline 1 & 1 & 0 & 0 & 1 \\
\hline 0 & 0 & 1 & 1 & 1 \\
\hline 0 & 0 & 1 & 1 & 1 \\
\hline 0 & 0 & 0 & I & 1 \\
\hline 0 & 0 & 0 & 0 & 1 \\
\hline 0 & 0 & 0 & 0 & 0 \\
\hline $\begin{array}{c}2000.0 \\
0\end{array}$ & $\begin{array}{l}2000.0 \\
2000.0\end{array}$ & $\begin{array}{l}2000.0 \\
2000.0\end{array}$ & $\begin{array}{l}2000.0 \\
2000.0\end{array}$ & $\begin{array}{l}8766.0 \\
8766.0\end{array}$ \\
\hline 0.2 & 0.2 & 0.2 & 0.2 & 0.2 \\
\hline NA & Anspaugh & Anspaugh & Anspaugh & Mass loading \\
\hline NA & 0 & 0 & 0 & -1 \\
\hline NA & 1.0 & 1.0 & 1.0 & NA \\
\hline NA & NA & NA & NA & 1.0 \\
\hline NA & NA & 1.0 & 1.0 & 1.0 \\
\hline NA & NA & 0.0 & 0.0 & 0.0 \\
\hline NA & NA & 1.0 & 1.0 & 1.0 \\
\hline 0 & 0 & 0 & 10 & 0 \\
\hline $\begin{array}{l}\text { Total } \\
\text { body }\end{array}$ & $\begin{array}{l}\text { Total body, } \\
\text { bone. lungs, } \\
\text { thyrold. } \\
\text { GI tract }\end{array}$ & $\begin{array}{l}\text { Total body, } \\
\text { bone, lungs, } \\
\text { thyrold, } \\
\text { GI tract }\end{array}$ & $\begin{array}{l}\text { Total body, } \\
\text { bone, lungs. } \\
\text { thyroid, } \\
\text { GI tract }\end{array}$ & $\begin{array}{l}\text { Total body, } \\
\text { bone, lungs, } \\
\text { thyrold, } \\
\text { GI tract }\end{array}$ \\
\hline
\end{tabular}

$\begin{array}{ccccc}1 & 1 & 1 & 10 & 1 \\ 50 & 50 & 50 & 59 & 50 \\ 1.0 & 1.0 & 1.0 & 1.0 & 1.0\end{array}$




\section{TABLE 3.2-2. Sample Problem Parameter Values}

Sample Problem

\begin{tabular}{|c|c|c|c|c|c|}
\hline Puthways. & 1 & 2 & 3 & 4 & -5 \\
\hline $\begin{array}{l}\text { External exposure to slab } \\
\text { source of waste (IEXT) }\end{array}$ & 1 & 1 & 0 & 0 & 1 \\
\hline $\begin{array}{l}\text { External exposure to an } \\
\text { infinite plane of raste } \\
\text { (ISUR) }\end{array}$ & 0 & 0 & 1 & 1 & 1 \\
\hline Food consumption (IFOD) & 0 & 0 & 1 & 1 & 1 \\
\hline $\begin{array}{l}\text { Orinking water consumption } \\
\text { (IWAT) }\end{array}$ & 0 & 0 & 0 & 1 & 1 \\
\hline $\begin{array}{l}\text { Aquatic food product } \\
\text { consumption (IARG) }\end{array}$ & 0 & 0 & 0 & 0 & 1 \\
\hline A\}r submersion (IAIR) & 0 & 0 & 0 & 0 & 0 \\
\hline $\begin{array}{l}\text { Hours of exposure: } \\
\text { To externat } \\
\text { To inhalation }\end{array}$ & $\begin{array}{c}2000.0 \\
0\end{array}$ & $\begin{array}{l}3000.0 \\
3000.0\end{array}$ & $\begin{array}{l}2000.0 \\
2000.0\end{array}$ & $\begin{array}{l}2000.0 \\
2000.0\end{array}$ & $\begin{array}{l}2000.0 \\
2000.0\end{array}$ \\
\hline Waste oflution factor (SRDIL) & 0.2 & 0.2 & 0.2 & 0.2 & 0.2 \\
\hline $\begin{array}{l}\text { Resuspension Model: } \\
\text { Age of contamination } \\
(y r) \text { (AGE) }\end{array}$ & NA & $\begin{array}{c}\text { Anspaugh } \\
0\end{array}$ & $\begin{array}{c}\text { Anspaugh } \\
0\end{array}$ & $\begin{array}{c}\text { Anspaugh } \\
0\end{array}$ & $\begin{array}{l}\text { Mass loading } \\
\text { NA }\end{array}$ \\
\hline $\begin{array}{l}\text { Thickness of surface soll } \\
\text { layer avallable }(\mathrm{cm})\end{array}$ & NA & 1.0 & 1.0 & 1.0 & NA \\
\hline $\begin{array}{l}\text { Ratio of waste concentration } \\
\text { in surface to subsurface } \\
\text { so11 (RPFI) }\end{array}$ & NA & NA & NA & NA & 0.0 \\
\hline $\begin{array}{l}\text { Fraction of total roots in } \\
\text { top } 15 \mathrm{~cm} \text { of sofl (RFl) }\end{array}$ & NA & NA & 1.0 & 1.0 & 0.6 \\
\hline $\begin{array}{l}\text { Fraction of total roots in } \\
\text { subsurface sol1 (RF2) }\end{array}$ & NA & NA & 0.0 & 0.0 & 0.4 \\
\hline $\begin{array}{l}\text { Fraction of diet grown on } \\
\text { s1te (RDF } 2 \text { ) }\end{array}$ & NA & NA & 1.0 & 1.0 & 1.0 \\
\hline $\begin{array}{l}\text { Years of prior trrigation } \\
\text { of s1te (IRR) }\end{array}$ & 0 & 0 & 0 & 10 & 10 \\
\hline Selected organs (KORG) & $\begin{array}{l}\text { Total } \\
\text { body }\end{array}$ & $\begin{array}{l}\text { Total body, } \\
\text { bone, lungs, } \\
\text { thyrold, } \\
\text { GI tract }\end{array}$ & $\begin{array}{l}\text { Total body, } \\
\text { bone, lungs, } \\
\text { thyrold, } \\
\text { GI tract }\end{array}$ & $\begin{array}{l}\text { Total body, } \\
\text { bone, lungs, } \\
\text { thyrold, } \\
\text { GI tract }\end{array}$ & $\begin{array}{l}\text { Total body, } \\
\text { bone, lungs, } \\
\text { thyro1d, } \\
\text { GI tract }\end{array}$ \\
\hline $\begin{array}{l}\text { No. of years after } \\
\text { waste is disposed that: } \\
\text { Scenarto begins (ITI) }\end{array}$ & 10 & 10 & 10 & 10 & 10 \\
\hline Scenario ends (IT2) & 59 & 59 & 59 & 59 & 59 \\
\hline Site size (ha) (FRSIZ) & 1.0 & 1.0 & 0.05 & 1.0 & 1.0 \\
\hline
\end{tabular}


Selected ONSITE input screens have been revised to clarify the use of the input parameters. Figure 3.2-1 depicts the revised ONSITE input screen for the radionuclide inventory modification factor SRDIL. Figure 3.2-2 shows the modffied ONSITE input screen for the contamination/sol 1 mixing parameter RPFl. The RPFl parameter is used only when contanination is assumed to be present in both the surface and subsurface soll. The first two onsite disposal scenarios (external exposure and inhalation) assume contaminated subsurface soil. The third and fourth scenarios (agricultural and (rrigation) assume contaminated surface soil. Only the fifth scenario (user defined) allows consideration of both surface and subsurface soll contamination. The RPFl parameter may be a useful parameter when model ing more complex agricultural scenarios. For instance, the waste may be deeply burfed, but mixing with the surface soil may occur to produce a diluted waste concentration in the surface sol1. For this situation, fractions of the plant roots may enter both contaminated soll zones.

The radionuclide inventory modification factor is: 0.20 (range $=(0.0$ to $1.0 E+20$, usua 11 y 0.0 to 1.0$)$

This factor will be used as a multiplier of all input concentrations. It is a handy parameter to correct units or make other changes (such as dilution of inventory with clean soil).

Do you wish to change this value $(N / Y)$ ?

FIGURE 3.2-1. Revised ONSITE Input Screen for Radionuclide Inventory Modification Factor - SRDIL

This scenario assumes contamination to both surface (top $15 \mathrm{~cm}$ ) and subsurface soil. Concentrations you input will be assumed to be in the subsurface soil.

What is the ratio of waste concentration in the surface to subsurface solls?

(Range $=0.0$ to 10.0 for sp $111 \mathrm{~s}$, usual 1 y 0.0 to 1.0 to a) low redistribution from buried material to surface)

The current selection is: 1.00

Do you wish to change this value $(N / Y)$ ?

FIGURE 3.2-2. Revised ONSITE Input Screen for Soll Contamination Distribution Parameter - RPFl 
Selected input parameters for ONSITE/MAXIl are described in Table 3.2-3. Descriptions are given in greater detail than in Napier et a1. (1984).

\section{IABLE 3.2-3. ONSITE/MAXI I Parameter Descriptions}

NAMELIST

Parameter Set/No. Array

Name

AGE

AREAEX

AREA IN

IEXT

ISUR
INPUT

INPUT

INPUT

INPUT

Real

Real

Rea 1

Integer

INPUT
Data Type

Description

Anspaugh model. Average age in years of surface contamination at the beginning of the calculation in years. This factor accounts for environmental weathering. This parameter is set to $-I$ to select the mass-loading resuspenston model. (Default value is 0 )

Area correction factor for external and inhalation pathways to account for the limited potential for exposure from smal ler disposal sites. This parameter is calculated by ONSITE based on the size of the site, FRSIZ. (Default value is 1.0)

Area correction factor for ingestion pathways to account for the limited potential for exposure from smaller disposal sites. This parameter is calculated by ONSITE based on the size of the site, FRSIZ. (Default value is 1.0)

External exposure and crop-root penetration pathway for waste mode1ed as a slab source. Waste may be stored aboveground, burled at the soll surface, or buried with a soll overburden. Al lowable values are:

0 - pathway not selected

1 - pathway selected

Option to consider external exposure to surface contamination model led as a plane source. This pathway is selected to consider elther a waste 
IABLE 3.2-3. (Contd)

\begin{tabular}{|c|c|c|c|}
\hline $\begin{array}{l}\text { Parameter } \\
\text { Name } \\
\end{array}$ & $\begin{array}{l}\text { NAMELIST } \\
\text { Set/No. Array } \\
\text { Elements } \\
\end{array}$ & Data Iype & Description \\
\hline \multirow[t]{2}{*}{ ISUR, contd } & & & $\begin{array}{l}\text { spill or agricultural activities as } \\
\text { defined in Scenarios } 3 \text { and } 4 \text {. A1- } \\
\text { lowable values are: } \\
0 \text { - pathway not selected } \\
1 \text { - pathway selected }\end{array}$ \\
\hline & & & $\begin{array}{l}\text { If this parameter is set to } 0 \text {, } \\
\text { XFACT wil be set to } 1.0 \text { in MAXIl. } \\
\text { (Default value is } 1 \text { ) }\end{array}$ \\
\hline ITI & INPUT & Integer & $\begin{array}{l}\text { The year after waste disposal when } \\
\text { intrusion occurs and the annual } \\
\text { dose calculation begins. This } \\
\text { parameter al lows for correct chain } \\
\text { decay of source term. (Default } \\
\text { value is l or IRR, whichever is } \\
\text { greater) }\end{array}$ \\
\hline RPFl & INPUT & Real & $\begin{array}{l}\text { This is a ratio of waste concentra- } \\
\text { tion in surface to subsurface soils. } \\
\text { This parameter is used only when } \\
\text { contamination is assumed to be pre- } \\
\text { sent in both surface (top } 15 \mathrm{~cm} \text { ) } \\
\text { and subsurface soil. RPF } 1 \text { al lows } \\
\text { redistribution of the waste in the } \\
\text { soil. Ranges: l.0 to } 10.0 \text { for inci- } \\
\text { dental surface contamination, } 0.0 \\
\text { to l.0 for buried to surface redis- } \\
\text { tribution. (Default value is } 1.0 \text { ) }\end{array}$ \\
\hline RPF2 & INPUT & Rea] & $\begin{array}{l}\text { Fraction of the total selected diet } \\
\text { grown on the site. RPF } 2 \text { must be } \\
\text { greater than } 0.0 \text {. (Default value } \\
\text { is } 1.0 \text { ) }\end{array}$ \\
\hline SRDIL & INPUT & Rea1 & $\begin{array}{l}\text { Inventory modification factor. This } \\
\text { factor is used as a multiplier of } \\
\text { al } 1 \text { input concentrations. It is a } \\
\text { parameter used to correct units or } \\
\text { make other changes (such as dilution } \\
\text { of inventory th clean soil. } \\
\text { Range: } 0.0 \text { to } 1.0 \times 10^{20} \text { used to } \\
\text { correct units, } 0.0 \text { to } 1.0 \text { as a dilu- } \\
\text { tion factor. (Default value is } 1.0 \text { ) }\end{array}$ \\
\hline
\end{tabular}




\subsection{ENHANCED INPUT FEATURES}

Two major enhancements have been added to the input procedure of the ONSITE computer program: 1) error checking of user input and 2) an on-1 ine table of acceptable radionuclide nomenclature. All user input is now read in FORTRAN CHARACTER format and checked for invalid entries before converting to a numeric format. This virtual iy el iminates user-caused program crashes. Figure 3.3-1 contains the 11st of radionuclides from which doserate factors are available in the ONSITE/MAXIl software package. This table is displayed at the beginning of the inventory entry and then optionaliy throughout the inventory entry period to assist the user with the input requirements.

Radionuclide inventory must be from the following list:

$\begin{array}{lllll}\text { H } 3 & \text { C } 14 & \text { NA22 } & \text { P 32 } & \text { P 33 } \\ \text { S 35 } & \text { CL36 } & \text { K 40 } & \text { CA45 } & \text { SC46 } \\ \text { CR51 } & \text { MN54 } & \text { FE55 } & \text { FE59 } & \text { CO57 } \\ \text { C060 } & \text { NI59 } & \text { NI63 } & \text { ZN65 } & \text { SE75 } \\ \text { SR85 } & \text { SR90+D } & \text { M093 } & \text { NB94 } & \text { RU106+D } \\ \text { CD109 } & \text { AG110M+D } & \text { IN111 } & \text { SB124 } & \text { SB125+D } \\ \text { I 125+D } & \text { I 131+D } & \text { CS137+D } & \text { CE144+D } & \text { EU152 } \\ \text { EU154 } & \text { TB160 } & \text { OS185 } & \text { OS191 } & \text { IR192 } \\ \text { HG203 } & \text { PB210+D } & \text { RA226+D } & \text { TH228+D } & \text { TH230+D } \\ \text { TH232+D } & \text { U 233+D } & \text { U 234 } & \text { U 235+D } & \text { U 238+D } \\ \text { NP237+D } & \text { PU241+D } & \text { SR89 } & \text { Y 89M } & \text { SR90 } \\ \text { Y 90 } & \text { MO99 } & \text { TC99M } & \text { TC99 } & \text { RU103 } \\ \text { PD103 } & \text { RH103M } & \text { I 129 } & \text { CS134 } & \text { CS135 } \\ \text { CS137 } & \text { BA137M } & \text { CE141 } & \text { SM151 } & \text { U 235 } \\ \text { TH231 } & \text { PA231 } & \text { AC227 } & \text { TH227 } & \text { FR223 } \\ \text { RA223 } & \text { NP237 } & \text { PA233 } & \text { U 233 } & \text { TH229 } \\ \text { RA225 } & \text { AC225 } & \text { U 238 } & \text { TH234 } & \text { PA234M } \\ \text { PA234 } & \text { PU242 } & \text { NP238 } & \text { PU238 } & \text { CM244 } \\ \text { PU244 } & \text { U 240 } & \text { PU240 } & \text { CM243 } & \text { PU243 } \\ \text { AM243 } & \text { NP239 } & \text { PU239 } & \text { PU241 } & \text { AM241 }\end{array}$

Press any key to continue... <cr>

FIGURE 3.3-1. Input Screen of Radionuclides Considered in the ONSITE/MAXIl Software Package 


\subsection{SAMPLE PROBLEM - STORED WASTE SCENARIO}

As discussed in Section 2.1, the Stored Waste Scenario is a sub-set of the External Exposure Scenario. To activate the stored waste option, the user simply selects the stored waste external-exposure dose-conversion factors (option 5 in Figure 2.2-3), as discussed in Section 2.1.5. To further document this option, a sampie problem is included in this section, For this sample problem, a 1 icensee is assumed to dispose of $100 \mathrm{~m}^{3}$ of noncompacted waste in drums in an aboveground storage facllity. The waste is assumed to contain an average of $0.1 \mathrm{ci} / \mathrm{m}^{3}$ of $60 \mathrm{Co}$ and have a density of $1.0 \mathrm{~g} / \mathrm{cm}^{3}$. The resulting dose to an intruder who enters the storage facility a few weeks after the wastes are disposed of and stays there for $500 \mathrm{~h}$ of exposure is determined by running the ONSITE default externalexposure scenario with the user responses shown in the ONSITE interactive session given in Figure 3.4-1 (on the next page). It should be noted that the ONSITE program asks for an inventory modification factor and that a value of 0.2 is used for the sample problem. This factor accounts for the mixing of the radioactive waste with nonradioactive materials like drums or packaging materials or noncontaminated soil for the case of 1 and disposal. For consistency with the other sample problems given in Napier et a 1.(1984), the factor of 0.2 is used; however, more approprlate values for stored waste may be closer to 1.0 and may be substituted by the user. ONSITE also asks about the site size, but for the stored waste scenario this question has 7 ittle meaning. The area correction question is left in ONSITE for the stored waste option to provide the user with another level to account for conditions that might further reduce the external-exposure pathway. The output for this sample problen 15 shown in Figure 3.4-2. The total-body dose to the intruder for this sample probiem is about 6.1 rem/yr.

\section{REFERENCES}

Napler, B. A., R. A. Peloquin, W. E. Kennedy, Jr. and S. M. Neuder. 1984. Intruder Dose Pathway Anaylsis for the Onsite Disposal of Radioactive Wastes: The ONSIIE/MAXII Computer Pregram. NUREG/CR-3620. U.S. Nuclear Regulatory Commission, Washington, D.C. 


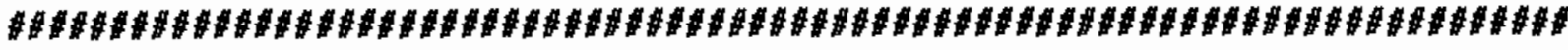

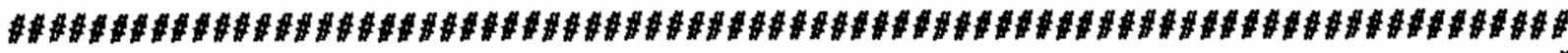$$
\#
$$$$
\#
$$$$
\#
$$

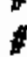$$
\text { \# }
$$$$
\#
$$

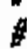

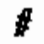$$
\#
$$$$
\#
$$

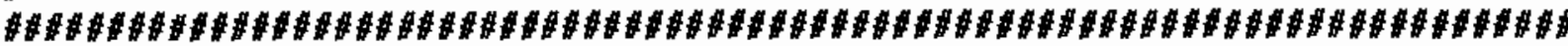

1) If the default condition is selected, you need only press <return>. YES-or-NO questions are designated by (Y/N) and should be answered with a $Y$ or $N$. The default condition is always listed first.

2) The values you enter 111 be tested against reasonable limits and if they are not accepted you will be asked to supply another value.

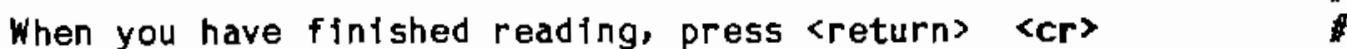


\# \#

The following scenarios have been defined:

1 - External exposure

2 - External exposure plus inhalation from resuspension

3 - Agricultural activities

4 - Use of well water for irrigation and drinking water

5 - User-created scenario

To select a scenario or for additional information on a scenario enter $1,2,3,4$, or $5: 1$ 〈cr $\rangle$

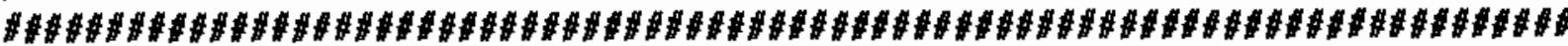

FIGURE 3.4-1. Input for the Stored Waste Scenario Sample Problem 


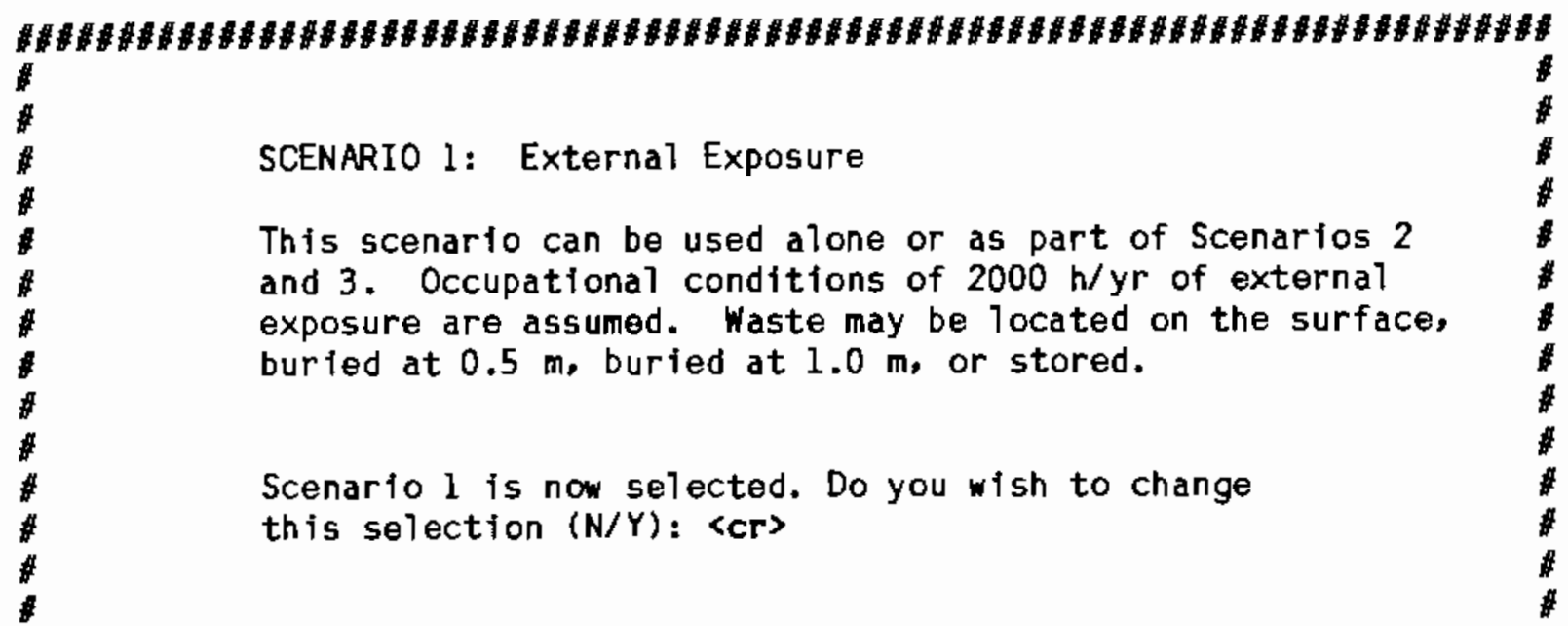

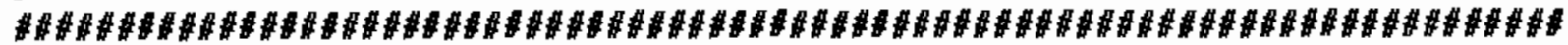

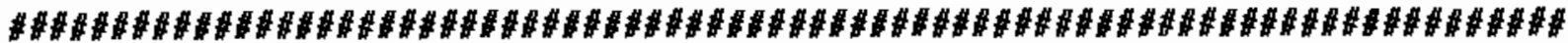

\#

$\#$

$\$$

\# Enter a descriptive tit\}e to identify this case:

Stored Waste Sub-set of the External Exposure Scenario <cr>

\#

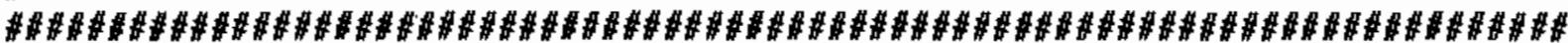

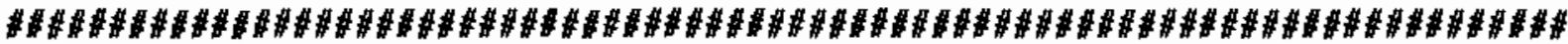

Three of printer reports are available:

0- Tables of maximum annual dose per organ with radionuclide and pathway contribution

1- Table above plus annual doses by organ and total

2- Table above plus annual doses by organ, pathway and radionuclide

4- Table above plus maximum by organ and radionuclide

The current selection is: 0

Do you wish to change this value $(N / Y)$ ? 〈cr

$\#$

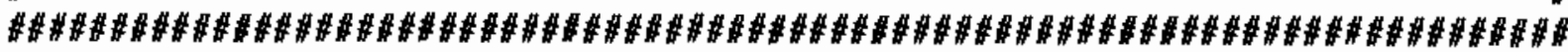

FIGURE $3.4-1$. (Contd) 


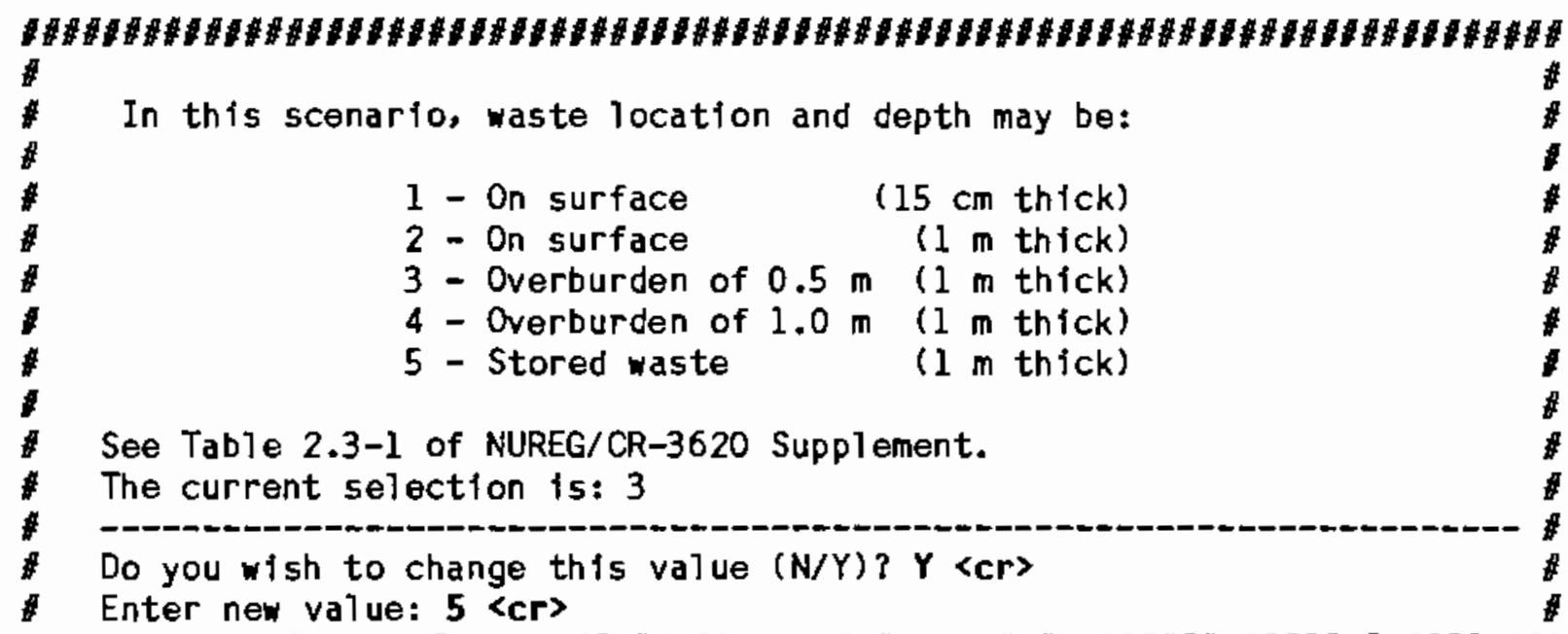

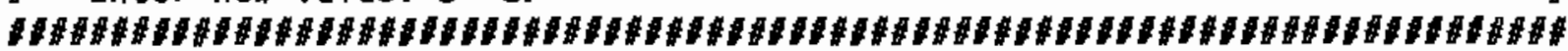

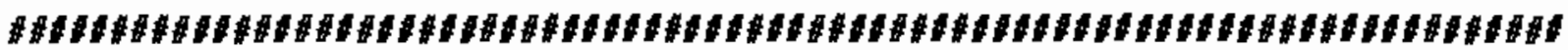

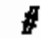

The size of the site in terms of fractional hectares

$(1 . e ., 10000 \mathrm{sq} \mathrm{m})$, is 1.00

\section{Do you wish to change this value $(N / Y)$ ? $\langle\mathrm{cr}\rangle$}

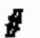

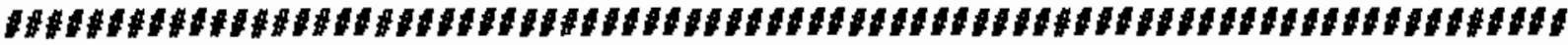

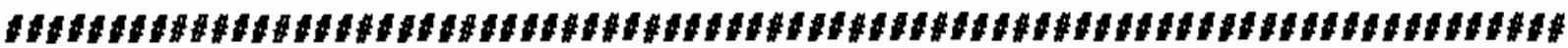

The inventory will automatically be adjusted by the approprlate area correction factor for each exposure pathway based on a site size of 1.00 hectares.

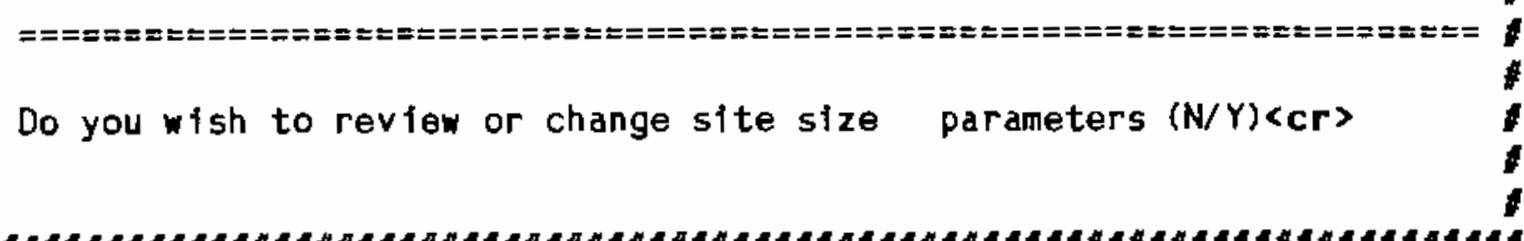

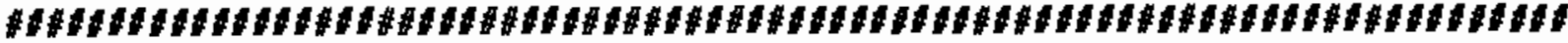

EIGURE 3.4-1. (Contd) 

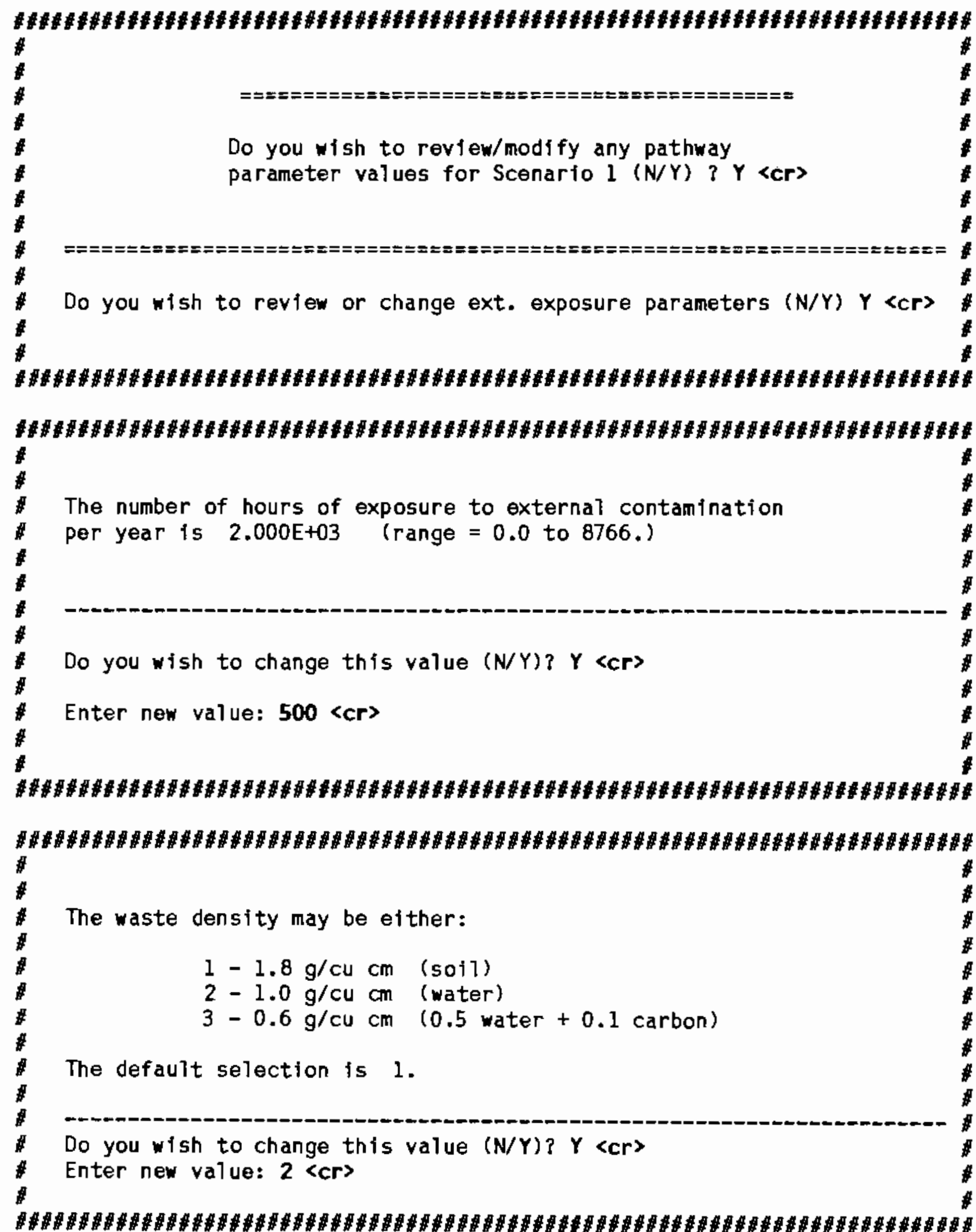

FIGURE 3.4-1. (Contd) 


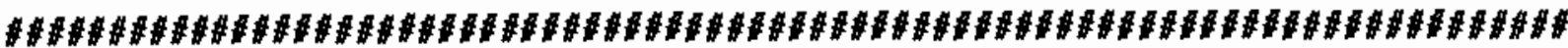



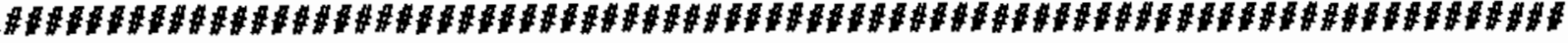



H

The dose calculations begin 1 years after the waste is disposed.

Do you wish to change this value $(N / Y)$ ? $Y\langle c r\rangle$

Enter new value: 0 <cr

The dose calculations $w 111$ end 49 years after the waste is

disposed. OK? $(Y / N)$ (cr)

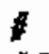

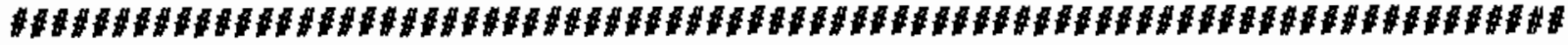

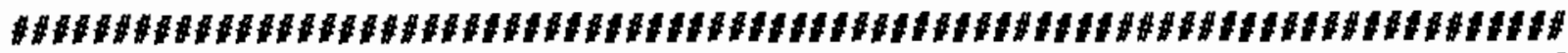

- The surface/buried inventory may be entered as:

$$
\begin{aligned}
& 1-\mathrm{pCl} \\
& 2-\mathrm{uCl} \\
& 3-\mathrm{mCj} \\
& 4-\mathrm{Cl}
\end{aligned}
$$

The current selection is: 1

Do you wish to change this value $(N / Y)$ ? $Y$ 〈Cr

Enter new value: 4 〈cr〉

1

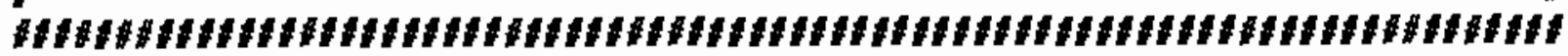

EIGURE 3.4-I. (Contd) 
The contamination deposited on the site at start of

calculation may be entered in the following unfts:

0 - Ci /square meter

1 - Ci /cubic meter

2 - Ci $/ \mathrm{Kg}$ of soll

Usually 0 for surface contamination and I for buried contamination. The current selection is: 1

Do you wish to change this value $(N / Y)$ ? 〈cr

\#



\#

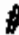

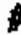

$\#$

$\$$

\#

$\$$

$\#$

\#

$\#$

$\#$

\#

\#

The radionuclide inventory modification factor is: $\quad 0.20$

( range $=0.0$ to $1.0 \mathrm{E}+20$, usua 7 ly 0.0 to 1.0 )

This factor will be used as a multiplier of all input

concentrations. It is a handy parameter to correct units

or make other changes (such as dilution of inventory with

clean soli).

Do you wish to change this value $(N / Y)$ ? $\langle\mathrm{Cr}\rangle$

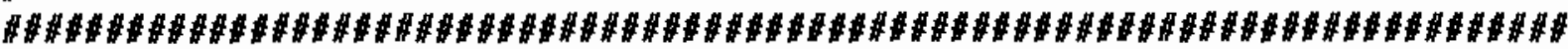

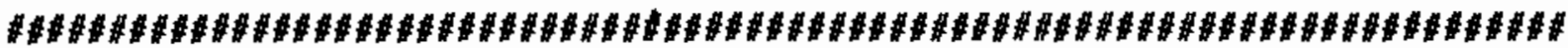

$\#$

$\#$



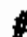

\#

\#

$\#$

\#

\#

\#

$\#$

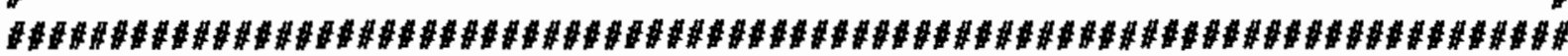

EIGURE 3.4-1. (Conto) 


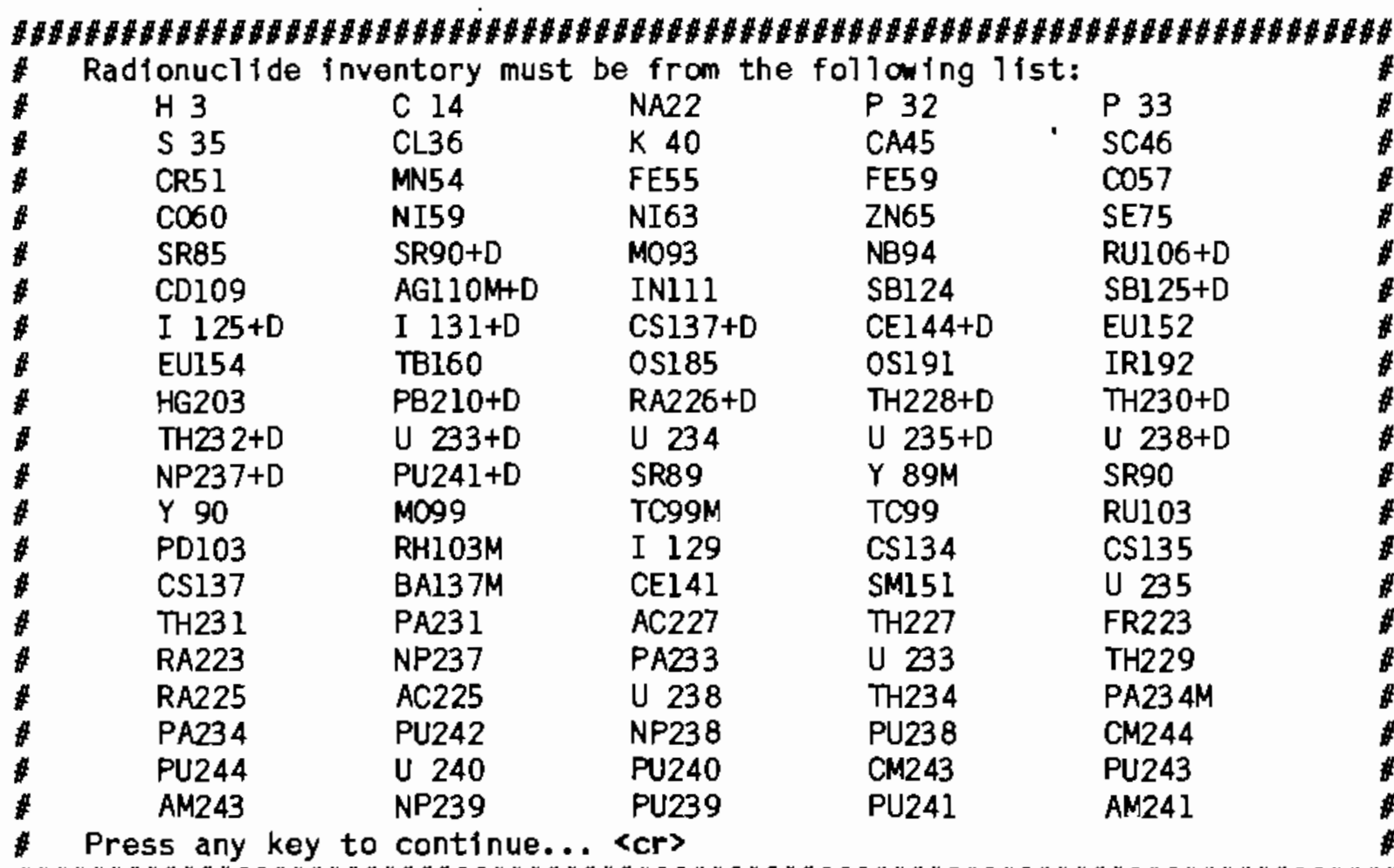

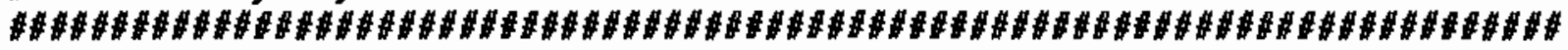



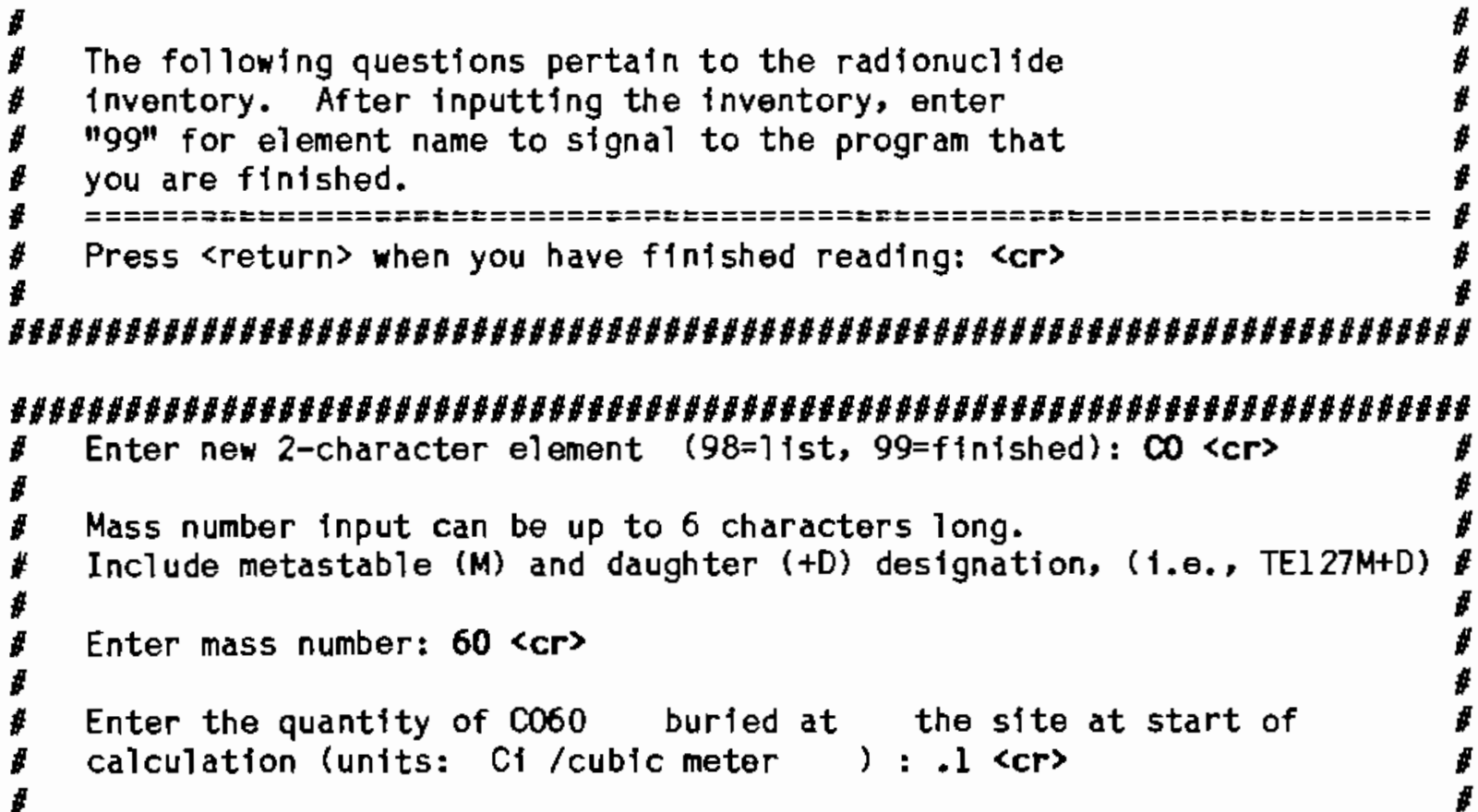

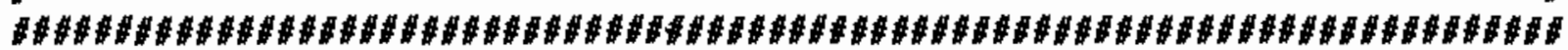

EIGURE 3,4-1. (Cont $\delta$ ) 


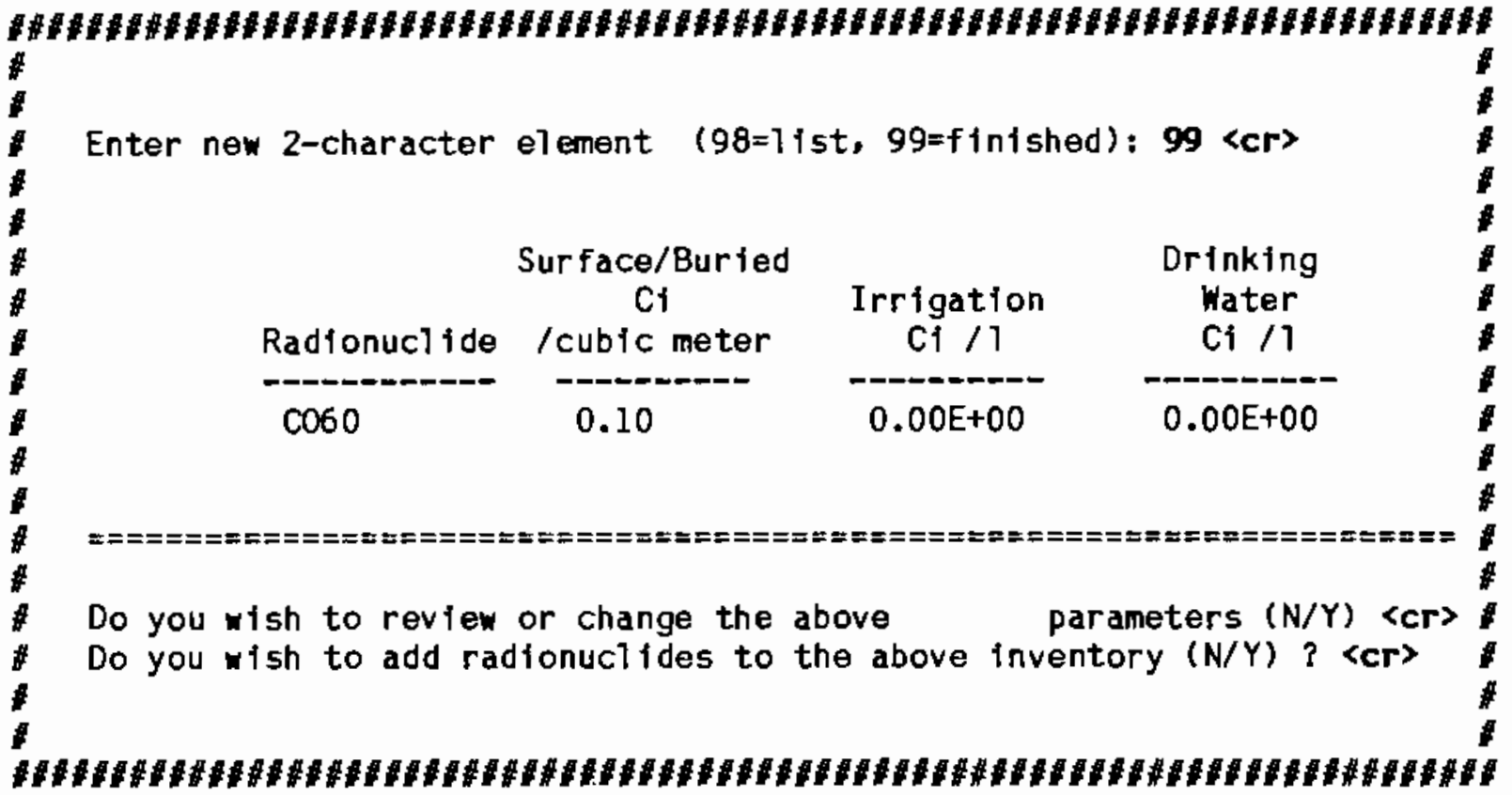

(The above interactive session generates the following file.)

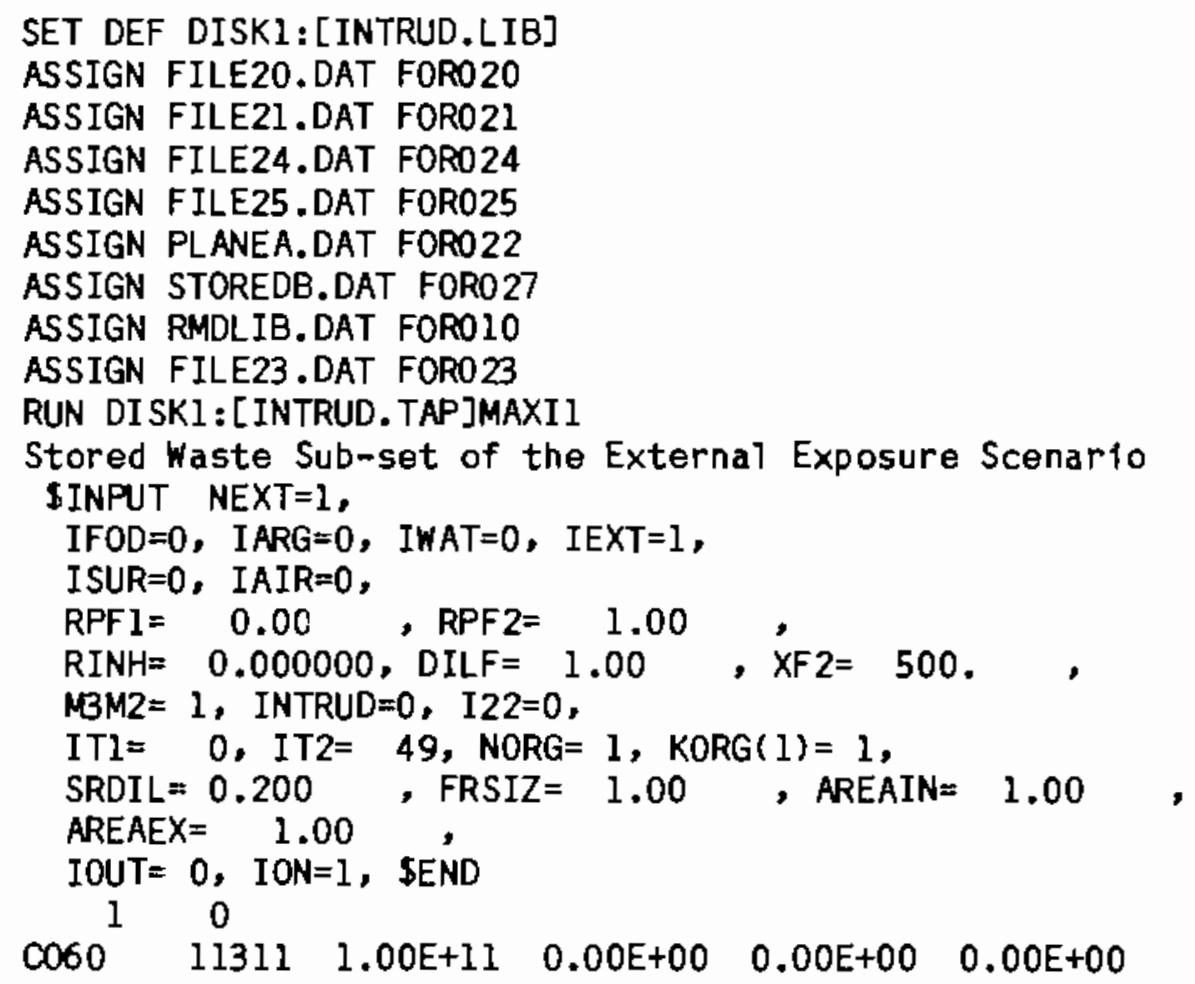

FIGURE 3.4-1. (Contd) 
MaXI - Maximum Annual Dose Calculation Version VAX2.2 2-APR-85

Executed on 15-MAY-85 at 14:58:18

Exposure 5cenario

RADIONUCLIDE CHAIN LIBRARY USED: RADIONUCLIDE MASTER DATA LIBRARY /W TRANSLOCATION CLASSES. 19-MAR-85 RAP DOSE FACTOR FILES USED FOR THIS CASE:

* 27 ISOSHLD EXTERNAL: STORED: 1.0 M THICK FINITE SLAB (DEN: H20 1.0) MR/HR

DOSES CALCULATED FROM O TO 49 YEARS FOLLOWING TIME ZERO

PATHWAYS INITIALIZED FOR DOSE CALCULATIONS: SPECIAL PARAMETERS INITIALIZED:

FARM PRODUCT INGESTION:

INHALATION OF RESUSPENDED MATERIAL:OFF

AOUATIC FOODS INGESTION: OFF

DRINKING WATER INGESTION: OFF

CONTINUING ATMOSPHERIC DEPOSITION OFF

$\begin{array}{ll}\text { EXTERNAL FROM BURIED WASTES } & \text { ON } \\ \text { EXTERNAL FROM SURFACE DEPOSITS: OFF }\end{array}$

FARM PRODUCT PARAMETERS USED:
FRACTION OF ROOTS IN UPPER SOIL: $0.10 E+01$
FRACTION OF ROOTS IN BURIEO WASTE $0.00 E+00$
FRACTION OF TOTAL DIET GROWN ON SITE: $1.00 E+00$
IRRIGATION RATE: $0.00 E+00 \mathrm{~L} / \mathrm{HA*} 2 / \mathrm{MO}$
MONTHS PER YEAR IRRIGATED:
6

DECAY OF RIYER RELEASE SOURCE TERM NOT PERFORMEO

DECAY OF AIR RELEASE SOURCE TERM NOT PERFORMED

SITE $X / Q: 0.00 E+00$

SPECIAL INHALATION MOOEL NOT USED

SIZE OF THE SITE: MODODOO FRACTIONAL HECTARES

INTERNAL PATHWAY AREA CORRECTION FACTOR: $1.00 E+00$

EXTERNAL EXPOSURE PARAMETERS USEO:

RATIO OF EXTERNAL CONTAMINATION IN SURFACE SOIL TO SUBSURFACE $50 \mathrm{IL}$ 0.00E+00

NUMBER OF HOURS OF EXPOSURE TO EXTERNAL CONIAMINATION $5.00 E+02$

SURFACE DEPOSITS DRFS FROM ISOSHLD; MODIF ICATION FACTOR: 5.844E-11

ORGANS FOR WHICH DOSES ARE CALCULATEO (SAME ORDER AS SOLUBILITIES GIVEN BELOW):

TOTAL BODY

INPUT PREPARED BY

DATE

INPUT CHECKEO BY

DATE

FIGURE 3.4-2. Output from the Stored Waste Scenario Sample Problem 
Stored Waste Sub-set of the External Exposure Scenario

MAXI, Version VAX2.2 2-APR-85 executed on 15-MAY-85 at 14:58:18.

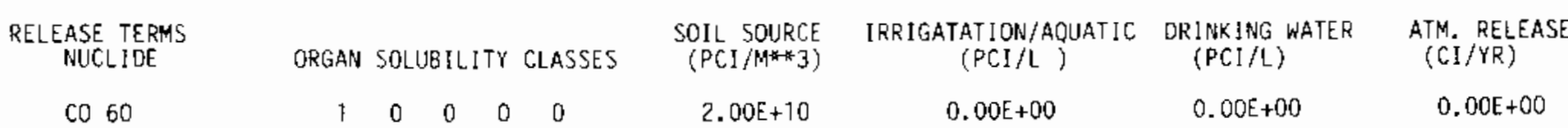

*
10000
$2.00 \mathrm{E}+10$
$0.00 \mathrm{E}+00$
$0.00 E+00$
$0.00 \mathrm{E}+00$

MLEAE NOTE ANY SPECIAL

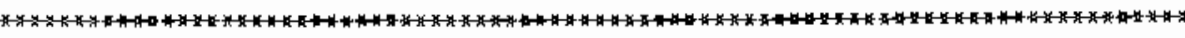

SOIL, AIR, ANO WATER CONCENTRATION SUMMARY FOR THE YEAR O

$\begin{array}{cccccc}\text { RADIONUCLIOE } & \begin{array}{c}\text { SURFACE SOIL } \\ \text { PCI/M2 }\end{array} & \begin{array}{c}\text { DEEP SOIL } \\ \text { PCI } / \mathrm{M3}\end{array} & \begin{array}{l}\text { AIR } \\ \text { PCI } / M 3\end{array} & \begin{array}{c}\text { IRRIGATION } \\ \text { PCI/L }\end{array} & \begin{array}{c}\text { ORINKING WATER } \\ \text { PCI/L }\end{array} \\ \text { C0 } 60 & 0.00 E+00 & 2.00 E+10 & 0.00 E+00 & 0.00 E+00 & 0.00 E+00\end{array}$

SOIL. AIR, ANO WATER CONCENTRATION SUMMARY FOR THE YEAR 49

\begin{tabular}{|c|c|c|c|c|c|}
\hline RADIONUCL IDE & $\begin{array}{c}\text { SURFACE SOIL } \\
\mathrm{PCI} / \mathrm{M} 2\end{array}$ & $\begin{array}{l}\text { DEEP SOIL } \\
\text { PCI } / M 3\end{array}$ & $\begin{array}{l}\mathrm{AIR} \\
\mathrm{PCI} / \mathrm{M3}\end{array}$ & $\begin{array}{l}\text { IRRIGATION } \\
\mathrm{PCI} / \mathrm{L}\end{array}$ & $\begin{array}{l}\text { DRINKING WATER } \\
\text { PCI } / L\end{array}$ \\
\hline 0 & 00 & $E+07$ & $0.00 E+00$ & $0.00 E+00$ & $0.00 \mathrm{E}+00$ \\
\hline
\end{tabular}

MAXIMUM ANNUAL DOSE SUMMARY FOR THE YEAR O FORTOTAL BODY

\begin{tabular}{|c|c|c|c|c|c|c|c|c|c|c|c|}
\hline RAUIONUCLIDE & $\begin{array}{l}\text { INGESTION } \\
\text { REM }\end{array}$ & $\begin{array}{l}\text { EXPOSURE } \\
7\end{array}$ & $\begin{array}{l}\text { PATHWAY } \\
\text { INHALATION } \\
\text { REM }\end{array}$ & $\%$ & $\begin{array}{l}\text { EXTERNAL } \\
\text { REM }\end{array}$ & $\%$ & $\begin{array}{l}\text { AQUATIC } \\
\text { REM }\end{array}$ & $\%$ & $\begin{array}{l}\text { ORINKING } \\
\text { REM }\end{array}$ & $\begin{array}{r}\text { AATER } \\
\%\end{array}$ & \\
\hline 0060 & $0.00 E+00$ & 0 & $0.00 E+00$ & 0 & $6.10 E+00$ & 100 & $0.00 \mathrm{E}+00$ & 0 & $0.00 E+00$ & 0 & \\
\hline \multirow[t]{2}{*}{ TOTALS } & INGESTION & $\%$ & INHALAT ION & $\%$ & EXTERNAL & $\%$ & AQUATIC & $10 \%$ & DRINK ING & NATER $\%$ & TOTAL \\
\hline & $0.00 E+00$ & 0 & $0.00 E+00$ & 0 & $6.10 E+00$ & 100 & $0.00 E+00$ & 0 & $0.00 E+00$ & 0 & $6.10 E+00$ \\
\hline
\end{tabular}

DIAGNOSTIC 1: ENO OF FILE ON INPUT, STOP FORTRAN STOP

FIGURE 3.4-2. (Contd) 



\subsection{PROGRAMMING DETAIL}

The changes and enhancements made to the ONSITE/MAXIl computer software package that are discussed in this supplement have not substantial ly altered the structure, organization, or operation of the computer programs. The changes made to the ONSITE and MAXIl computer programs are summarized below.

One additional subroutine, RDLIST, was added to ONSITE. RDLIST is called by RADIN to display the table of available radionuclides. Minor changes have been made to the following ONSITE subroutines: ONSITE, CHANGE, DISINV, MODIF, OUANTI, RADIN, RITFIL, and SCENR. Two parameters, IWD and IDT, were added to the ONSITE Common Block FLAG to store the selected waste density and diet options, respectively. Changes were also made to the MAXIl subroutine PADOS to apply the appropriate area correction factor for inhalation pathways. In addition, changes were made to OAPAGE and OUTPUT to record the date of this modification.

The VAX verston of the MAXIl computer program is listed in Appendix A. There are two notable differences between the $V A X$ and CDC versions of MAXI1. First, two different algorithms are used by the two versions to read the dose rate factor files. These algorithms are contained in the subroutines DFREAD and SETDAT. The difference concerns a trade-off between the amount of computer memory (CDC version) versus the amount of central processing time (VAX version) required for input operations. This mechanism is transparent to the user. The second difference is the addition of a fourth output option with the VAX version. The additional report summarizes the maximum year of exposure by radionuclide and organ.

As an additional quality assurance step, the sample problems described in Napter et a]. (1984) were run with the new version of the software and the results were compared with those previously documented. This was done to assure that no unpredictable changes or programming errors occurred during the software enhancement. A comparison was also made between the $V A X$ and CDC versions of the software to assure that both versions gave the same results. The sample problens documented in Napier et a 1. (1984) were used in these comparisons because hand calculations verified that the software was correctly doing all of the calculations. The results of these comparisons verified that both the $V A X$ and CDC versions of the enhanced software package were operating correctly.

\section{REFERENCES}

Napier, B. A., R. A. Peloquin, W. E. Kennedy, Jr., and S. M. Neuder. 1984. Intruder Dose Pathway Analysis for the Onsite Disposal of Radioactive Wastes: The ONSITE/MAXII Computer Program. NUREG/CR-3620. U.S. Nuclear Regu 7 atory Comission, Washington, D.C. 



\subsection{ERRATA}

The fol lowing corrections were inciuded in the ONSITE/MAXII software package since the original document was pubi ished in October 1984.

\subsection{UNITS CONYERSION - ONSITE}

In the ONSITE computer program (Napter et al. 1984), the correction factor for units of mCi to pCiwas changed from $1.0 \times 10^{6}$ to $1.0 \times 10^{9}$. This factor is stored in the third element of the array NVUNIT and initialized with a DATA statement.

\subsection{RUTHENIUM-103 DECAY CHAIN - RMDLIB/RMDONS}

The ${ }^{103}$ Ru decay chain in the files RMDLIB and RMDONS (Appendix 1.C, Napier et a 1. 1984) was corrected to read as follows:

$\begin{array}{lllllll}\text { RU103 } & 3.94 \mathrm{E}+1 & 1 & 0 & & 0 & \\ \text { PD103 } & 1.70 \mathrm{E}+1 & 2 & 0 & & 0 & \\ \text { RH103M } & 3.90 \mathrm{E}-2 & 3 & 1 & .9974 & 2 & .9997\end{array}$

\subsection{STRONTIUM-90 - ORGLIB}

A correction was made to the organ daty file ORGLIB, The biological half$11 \mathrm{fe}$ of $90 \mathrm{Sr}$ was ypdated from $1.3 \times 10^{4}$ to $4.0 \times 10^{3}$ days for total body and from $1.8 \times 10^{4}$ to $4.0 \times 10^{3}$ days for bone. The versions of FILE28, FILE21, FILE24, and FILE25 dated 4/85 contain dose rate factors for $90_{\mathrm{Sr}}$ with this shorter biological hal $\mathrm{f}-7$ ife. This change affects only ${ }^{90} \mathrm{Sr}$, the biological half-jife of ${ }^{90} \mathrm{Sr}+\mathrm{D}$ (the data entry that includes the short1 ived daughter $90_{Y}$ ) was correct.

\section{REFERENCES}

Napier, B. A., R. A. Poloquin, W. E. Kennedy, Jr., and S. M. Neuder. 1984. Intruder Dose Pathway Analysis for the Onsite Disposal of Radioactive Wastes: The ONSITE/MAXII Computer Program. NUREG/CR-3620. U.S. Nuclear Regu 1 atory Commission, Washington, D.C. 

APPENDIX $A$

COMPUTER CODE_LISIING - MAXII 
APPENDIX A COMPUTER CODE LISTING - MAXII

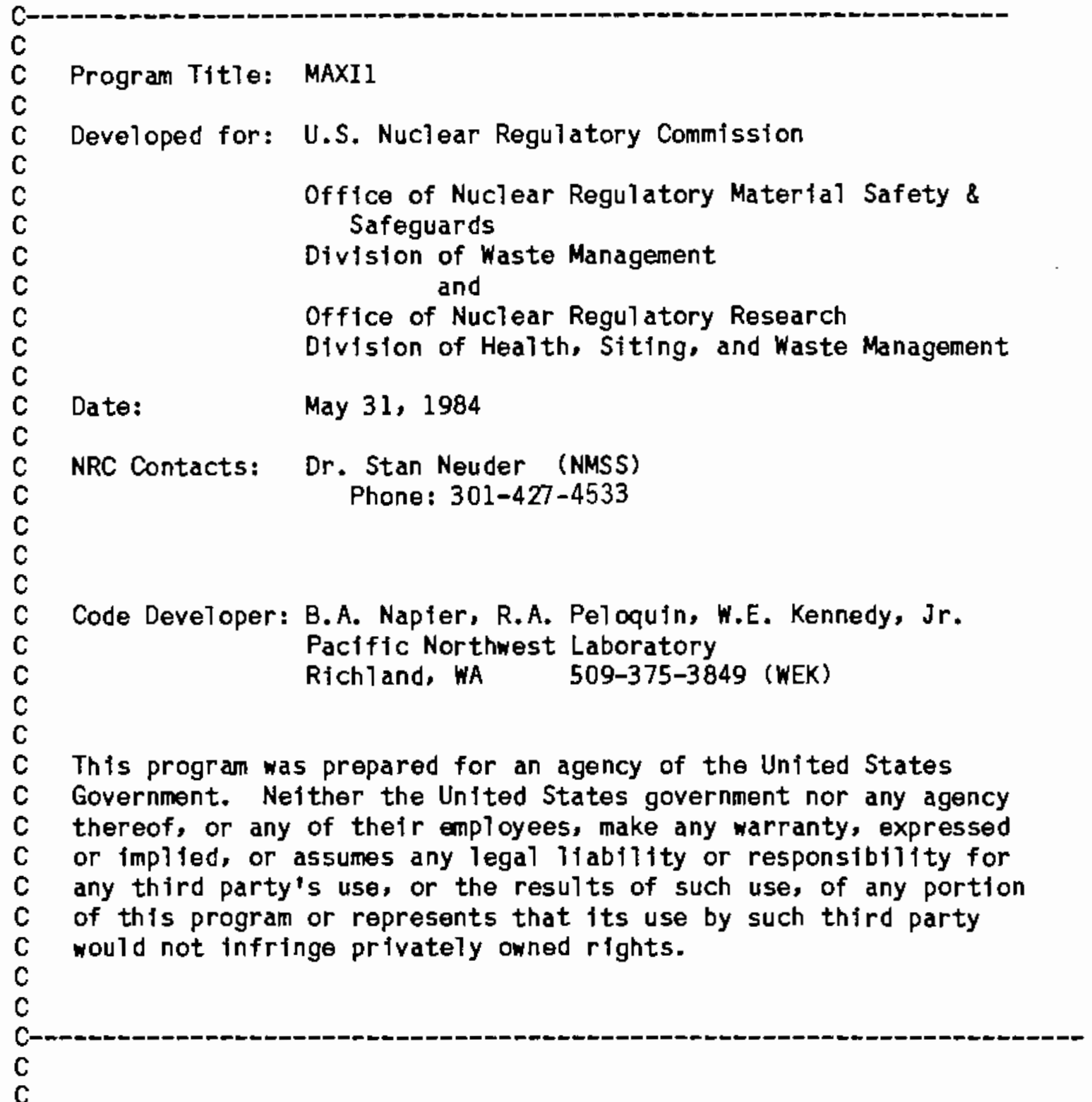

\section{PROGRAM MAXII}

C

C THIS PROGRAM IS DESIGNED TO CALCULATE ANNUAL RADIATION DOSES FROM

C INGESTION, INHALATION, EXTERNAL SURFACE CONTAMINATION,

C AND AQUEOUS FOOD AND WATER INGESTION RESULTING

C FROM RESIDUAL RADIOACTIVITY AT DECOMMISSIONED NUCLEAR FACILITIES

C AND WASTE STORAGE SITES.

C

C Version of May 31, 1985

C

C 
APPENDIX A COMPUTER CODE LISTING - MAXII

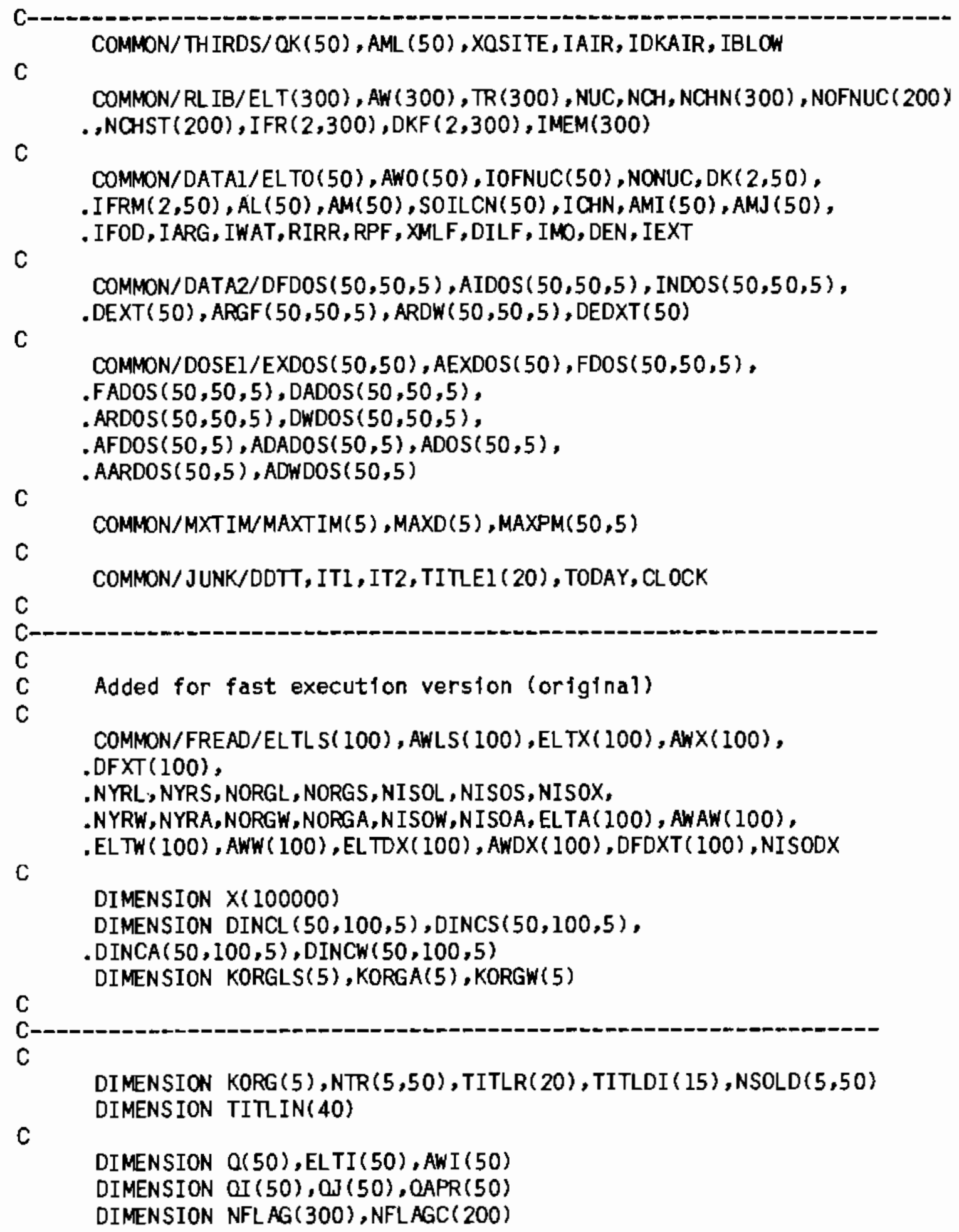




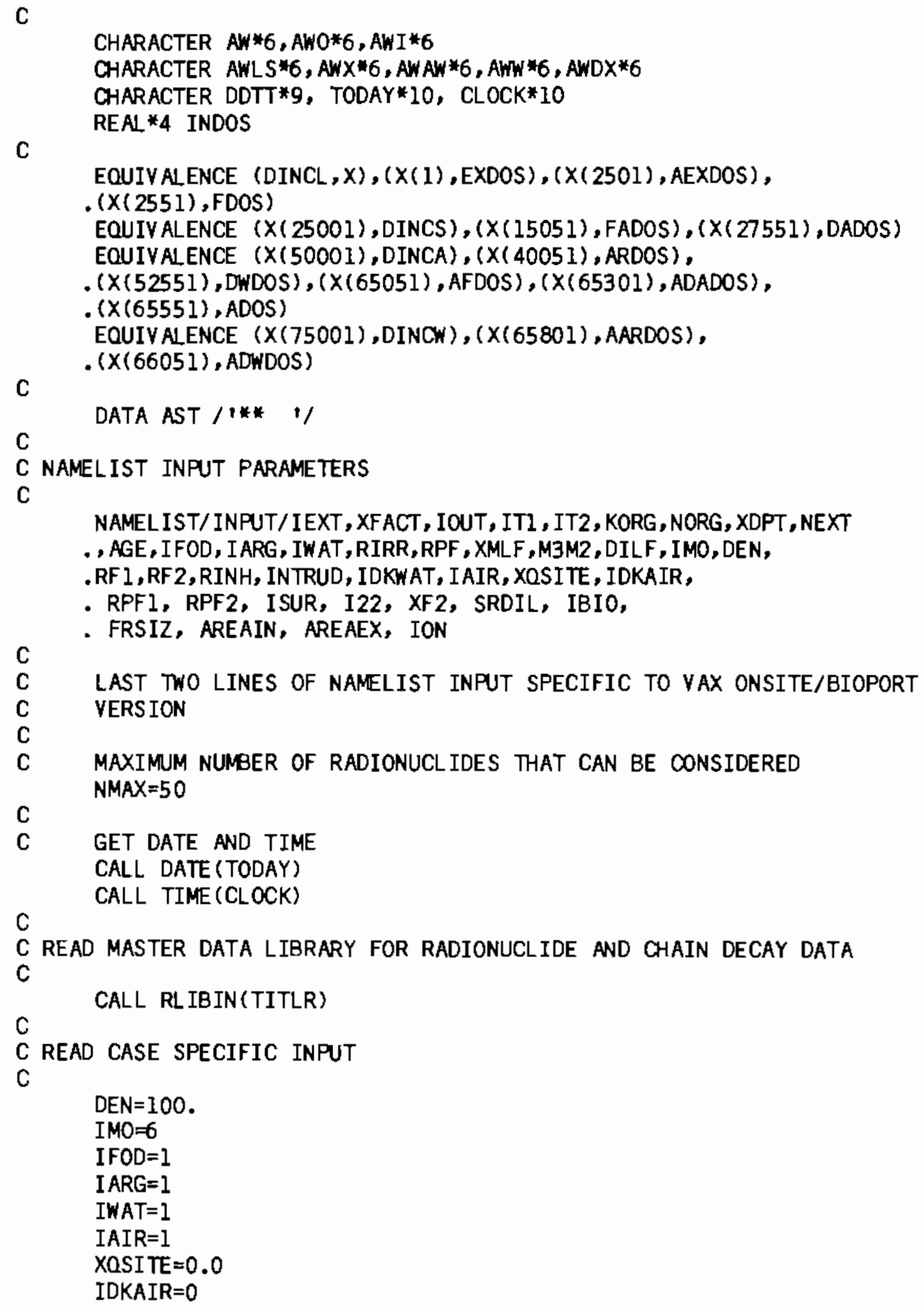


RPF $=1$

RPF $1=1.0$

RPF $2=0.0$

RIRR $=0.0$

$X M L F=0.01$

$M 3 M 2=0$

DILF $=1.0$

$A G E=-1.0$

IDKWAT $=0$

RIM $=1.0$

$\mathrm{XDPT}=0.067$

$X F A C T=1.0$

ISUR $=1$

I22 $=1$

XF2 $=0.0$

$\mathrm{ITI}=1$

RF $1=1.0$

RF2 $=0.0$

$\mathrm{RINH}=1.0$

IEXT $=0$

INTRUD $=0$

IT2 $=50$

$S R D I L=1.0$

C

$\operatorname{KORG}(1)=1$

$\operatorname{KORG}(2)=6$

$\operatorname{KORG}(3)=8$

$\operatorname{KORG}(4)=16$

$\operatorname{KORG}(5)=23$

$N O R G=5$

C

IBIO $=0$

ION $=0$

FRSIZ $=1.0$

AREAIN $=1.0$

AREAEX $=1.0$

C

C

C RPF $1=$ OLD RPF

C RPF $2=$ FRACTION OF TOTAL DIET GRONN ON SITE

C RPF =RPF1: IF RPF 2>0. THEN RPF = RPF1*RPF2

C ONLY RPF IS USED IN THE CALCULATION; RPFI, RPF2 USED FOR OA PAGE -RAP

C

C ISUR, I22, AND XF2 ARE THE ONSITE PARAMETERS EQUIVELENT TO XFACT

C ISUR = SURFACE CONTAMINATION (0-NOT CONSIDERED, 1-CONSIDERED)

C

C

$\mathrm{C}$

$X F 2=N 0.0 F$ HOURS/YEAR PERSON IS EXPOSED TO EXTERNAL CONTAMINATION 
APPENDIX A COMPUTER CODE LISTING - MAXII

C CODE LOGIC HAS BEEN ARRANGED SO THAT THE USER MAY STILL INPUT "XFACT"

C THROUGH NAMELIST. XFACT WILL ONLY BE SET BY MAXII IF VALUES HAVE BEEN

C INPUT FOR ISUR, I22, AND XFI

C

$1 \operatorname{READ}(5,50, \mathrm{END}=99)$ TITLEI

READ (UNIT $=5, N M L=I N P U T, E R R=97$ )

IF (NEXT.EQ.4)GO TO 95

C

C SET RIM VALUES BY M3M2

C

IF (M3M2.EQ.1) RIM $=0.15$

IF (M3M2.EO. 2) RIM=224.

C

C IF ONSITE INPUT, SET XFACT BASED ON VALUES OF ISUR, I22, AND XF2

IF (ISUR . EQ. O) THEN

$\mathrm{XFACT}=0.0$

ELSE

IF $(I 22, E Q .0) \quad X F A C T=5,844 E-11$

IF (XF2 .GT. O.) XFACT $=$ XFACT $*(X F 2 / 8766$.

ENDIF

$\mathrm{C}$

C IF ONSITE, SET RPF ELSE SET RPF I=RPF

IF (RPF2 ,GT. O.) THEN

$\mathrm{RPF}=\mathrm{RPFl} * \mathrm{RPF} 2$

ELSE

$\mathrm{RPF} 1=\mathrm{RPF}$

$\mathrm{RPF} 2=1.0$

ENDIF

C

C READ NEW ISOTOPE SELECTION

C NOTE: SUCCESSIVE CASES USE THE INITIAL INVENTORY

$\mathrm{C}$

C IF NOT BIOPORT INPUT, DO STANDARD INVENTORY INPUT

IF (IBIO .NE, 1) THEN

C

IF (NEXT.EQ.3) GO TO 100

$\operatorname{READ}(5,200, E N D=99) \mathrm{NIN}$, IRR, IBLOW

C

IF (NIN.GT.NMAX.OR. NIN.LT. 1) GO TO 98

$\operatorname{READ}(5,300, E N D=99)(\operatorname{ELTI}(I), \operatorname{ANI}(I),(N \operatorname{SOLD}(\mathrm{J}, I), J=1,5), Q(I)$,

$\mathrm{C}$ $O I(I), O J(I), O K(I), I=1, N I N)$

ELSE

C USE SPECIAL INVENTORY INPUT ROUTINE FROM BIOPORT

C 


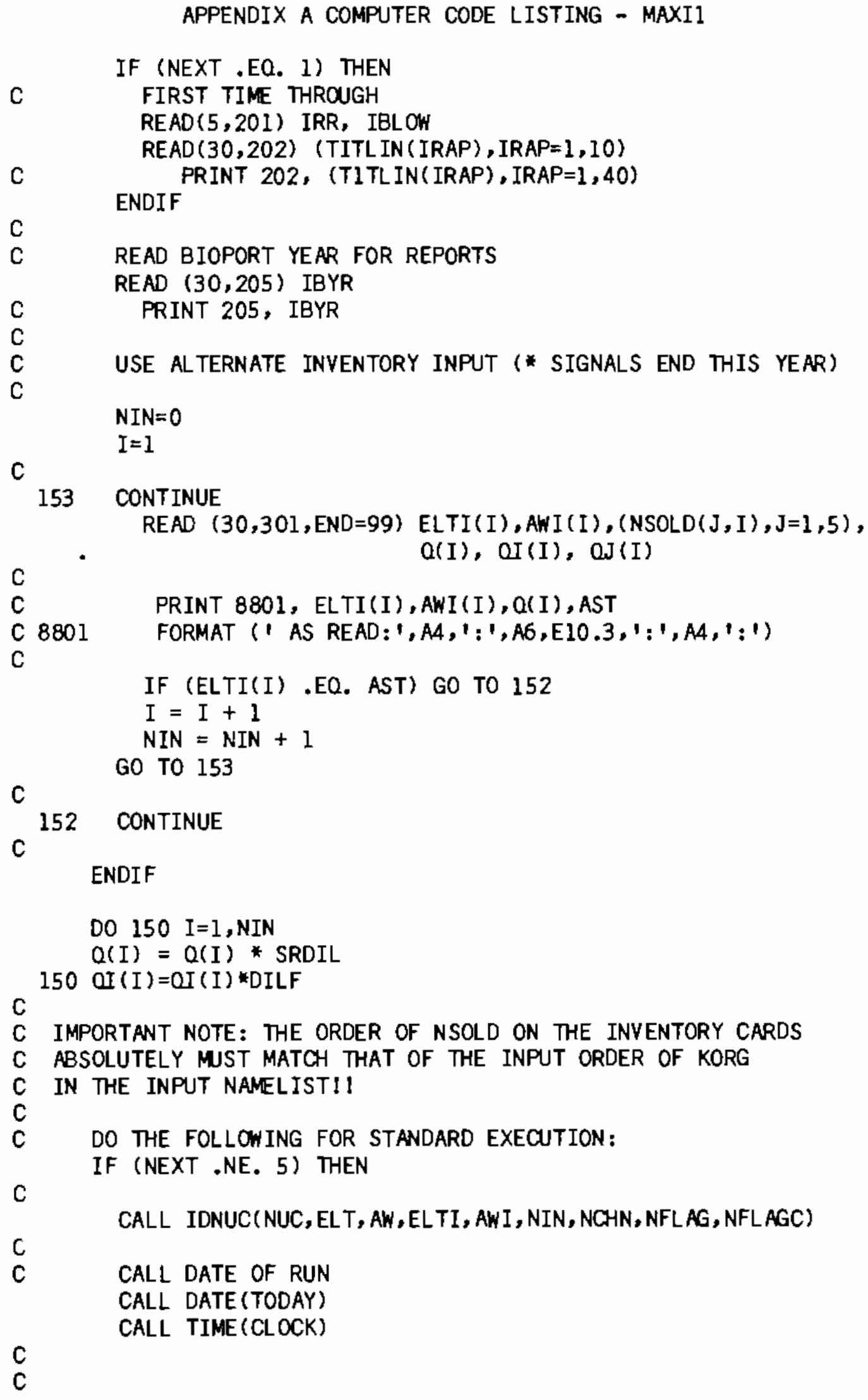


APPENDIX A COMPUTER CODE LISTING - MAXII

C READ AND SET DATA ARRAYS

C

CALL DFREAD (DINCL, DINCS, KORGLS, DINCA, DINCH, KORGA, KORGW)

C

C CALL SETDAT TO SET DATA IN CHAINS

C

CALL SETDAT(ELTI, AWI, NFLAG, NFLAGC, 0, DINCL,DINCS,

. KORG, KORGLS, NORG, NSOLD, NTR, OI, OJ, RIM,

. DINCA, DINCW, KORGA, KORGW, OAPR)

C

C

C SET INHALATION DATA ARRAY

CALL INSET (NORG, KORG,NTR,TITLDI)

C

100 CONTINUE

C

C

ELSE

C

C THIS IS SUBSEOUENT BIOPORT RUN, USE SPECIAL INITIALIZATION

CALL RDSUB ( $O, O I, O J, N F L A G, O A P R, R I M)$

C

ENDIF

C

$\mathrm{C}$

C CALL OAPAGE TO PRINT BACK PARAMETERS USED

$\mathrm{C}$

CALL OAPAGE (RF1,RF2, INTRUD, IDKWAT, XFACT, IRR, RINH, XDPT, AGE, , M3M2, KORG, NORG, NTR, TI TLR, TI TLDI, OAPR, RPF1, RPF 2, I SUR, I 22,

C . XF2 2, SRDIL, IBIO, IBYR, TITL IN, NEXT, FRSIZ, AREAIN, AREAEX, ION)

C SET AIR CONCENTRATIONS FROM OFF-SITE SOURCES

$\mathrm{C}$

IF(IAIR.NE.I)GO TO 160

DO $151 I=1$, NONUC

$151 \mathrm{AML}(\mathrm{I})=\mathrm{AML}(\mathrm{I}) * \times 0 S I T E * 3.175 E 4$

160 CONTINUE

$\mathrm{C}$

C CALCULATE PATHWAY DOSES

$\mathrm{C}$

CALL PADOS (XFACT, NORG, XDPT, AGE, IRR, RF 1, RF2, RINH, INTRUD, IDKW AT,

$\mathrm{C}$

$$
\text { - }
$$
XF2, RPF1, RPF2, AREAIN, AREAEX)

C CALCULATE ANNUAL DOSES

$\mathrm{C}$

CALL ANDOS(NORG)

$\mathrm{C}$

C DETERMINE MAXIMUM ANNUAL DOSE

C

CALL MAXDOS(NORG, NONUC) 
APPENDIX A COMPUTER CODE LISTING - MAXII

C

C PRINT OUTPUT RESULTS PAGE

$\mathrm{C}$

CALL OUTPUT (NORG, IOUT, KORG, IBIO, IBYR, NEXT)

C

C RECOVER AML FOR FUTURE CASES

C

IF (I AIR.NE. 1)GO TO 180

DO $170 \mathrm{I}=1$, NONUC

IF (XOSITE .GT. O.) THEN

$A M L(I)=A M L(I) /(X 0 S I T E * 3.175 E 4)$

ELSE

AML $(I)=0.0$

ENDIF

170 CONTINUE

C

180 CONTINUE

50 FORMAT (20A4)

200 FORMAT (3I5)

201 FORMAT (2I5)

202 FORMAT (20A4)

205 FORMAT (IX, I5)

300 FORMAT ( $A 2, A 6,5 I 1,4 E 10,2)$

301 FORMAT $(1 X, A 2, A 6,5 I 1,4 E 10.2)$

C

C IF (NEXT.GT.1) GO TO 1

GO TO 1

C

C

95 PRINT 400

STDP

99 PRINT 600

600 FORMAT(IHI,' DIAGNOSTIC 1: END OF FILE ON INPUT, STOPI) STOP

97 PRINT 700

700 FORMAT(' DIAGNOSTIC 2: ERROR ON NAMELIST INPUT') STOP

98 PRINT 800, NIN, NMAX

800 FORMAT( IHI, ' DIAGNOSTIC 3: ERROR IN NUMBER OF NUCLIDES ',

' INPUT, NONUC=1, I3, 'MAXIMUM ALLONED IS, 'I4)

400 FORMAT(IHI, 'DIAGNOSTIC 4 : END OF INPUT FOR THIS RUN, NORMAL 1 , ' TERMINATION')

$\mathrm{C}$

C

END 
APPENDIX A COMPUTER CODE LISTING - MAXII

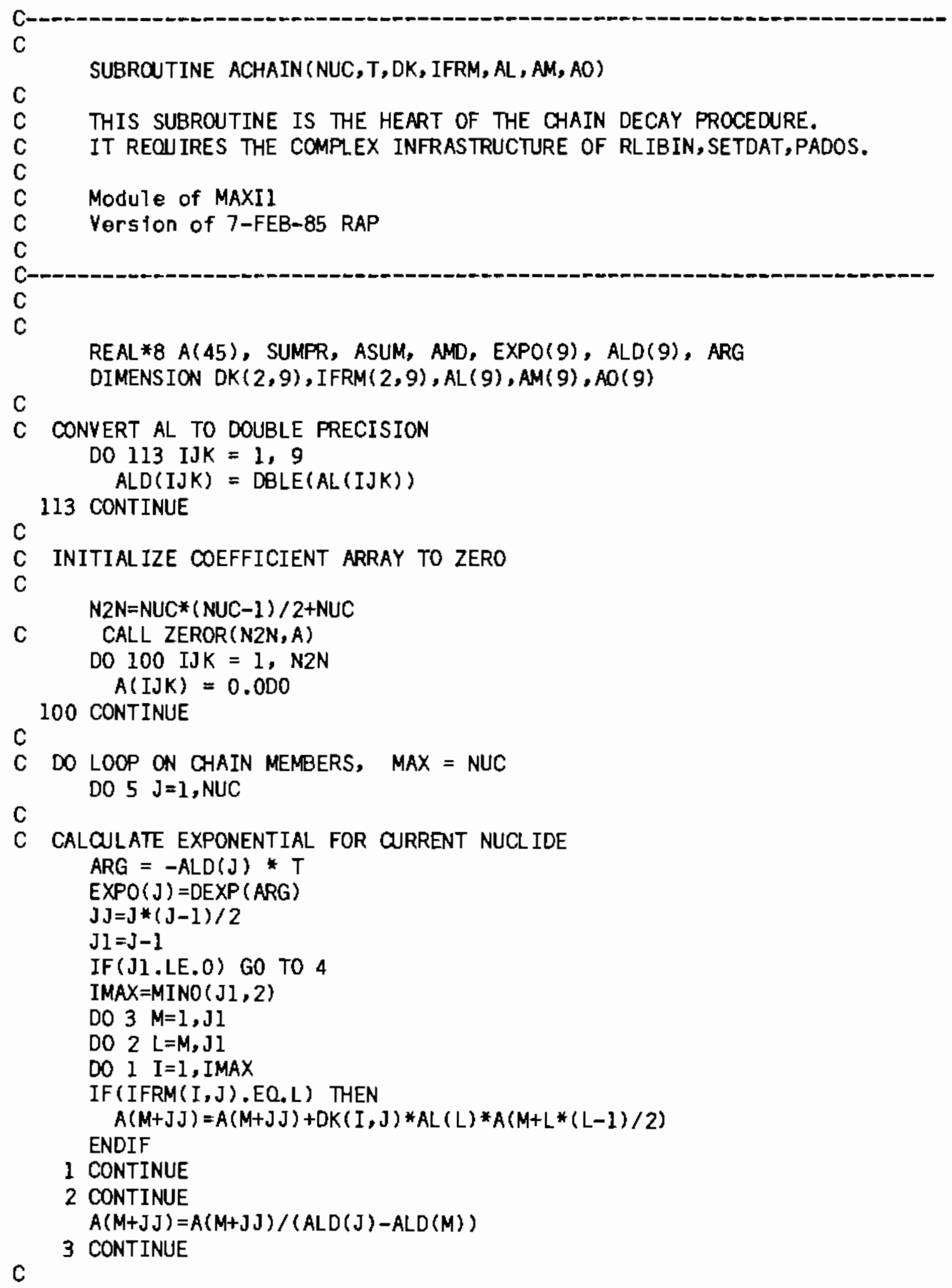


APPENDIX A COMPUTER CODE LISTING - MAXI 1

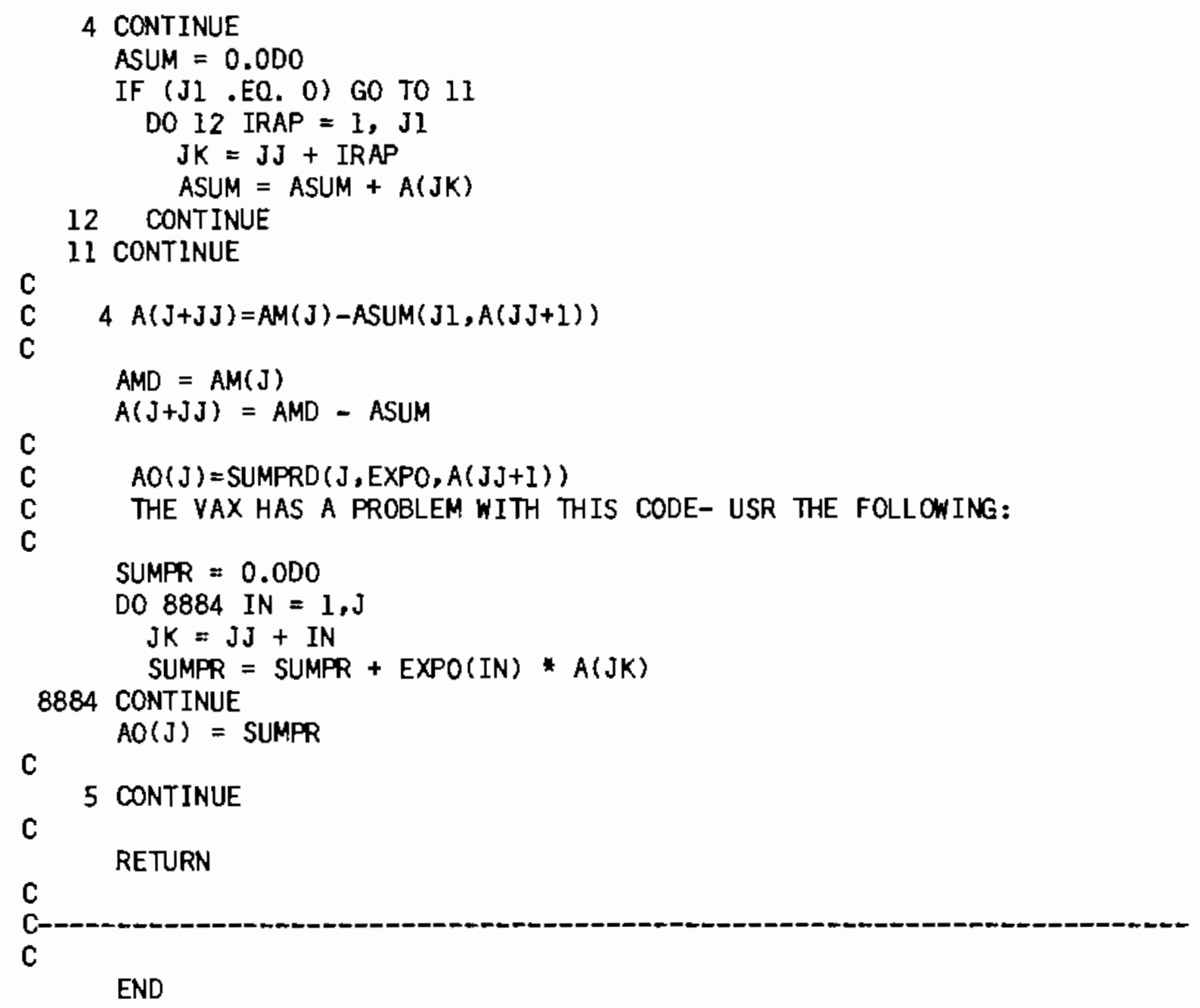


APPENDIX A COMPUTER CODE LISTING - MAXII

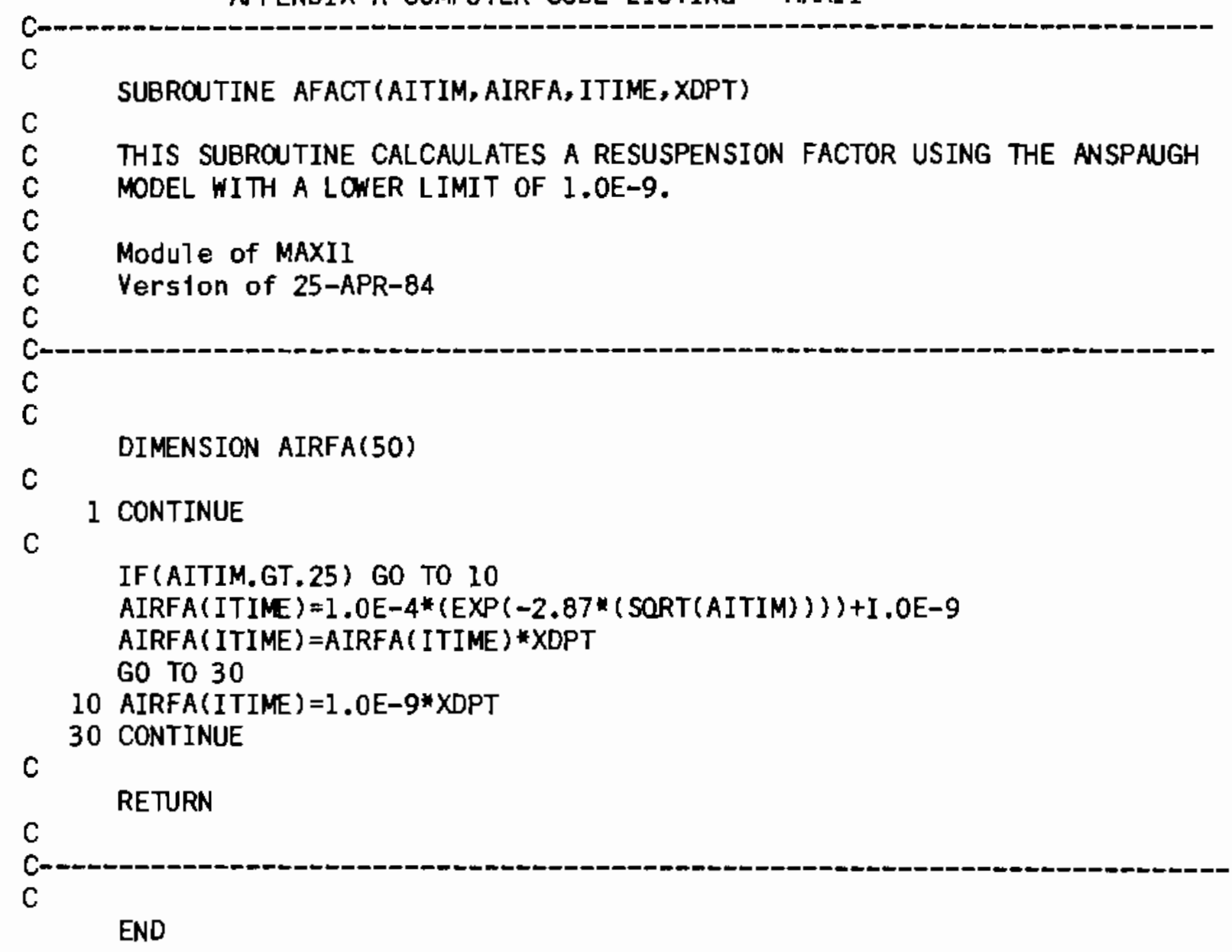


APPENDIX A COMPUTER CODE LISTING - MAXII

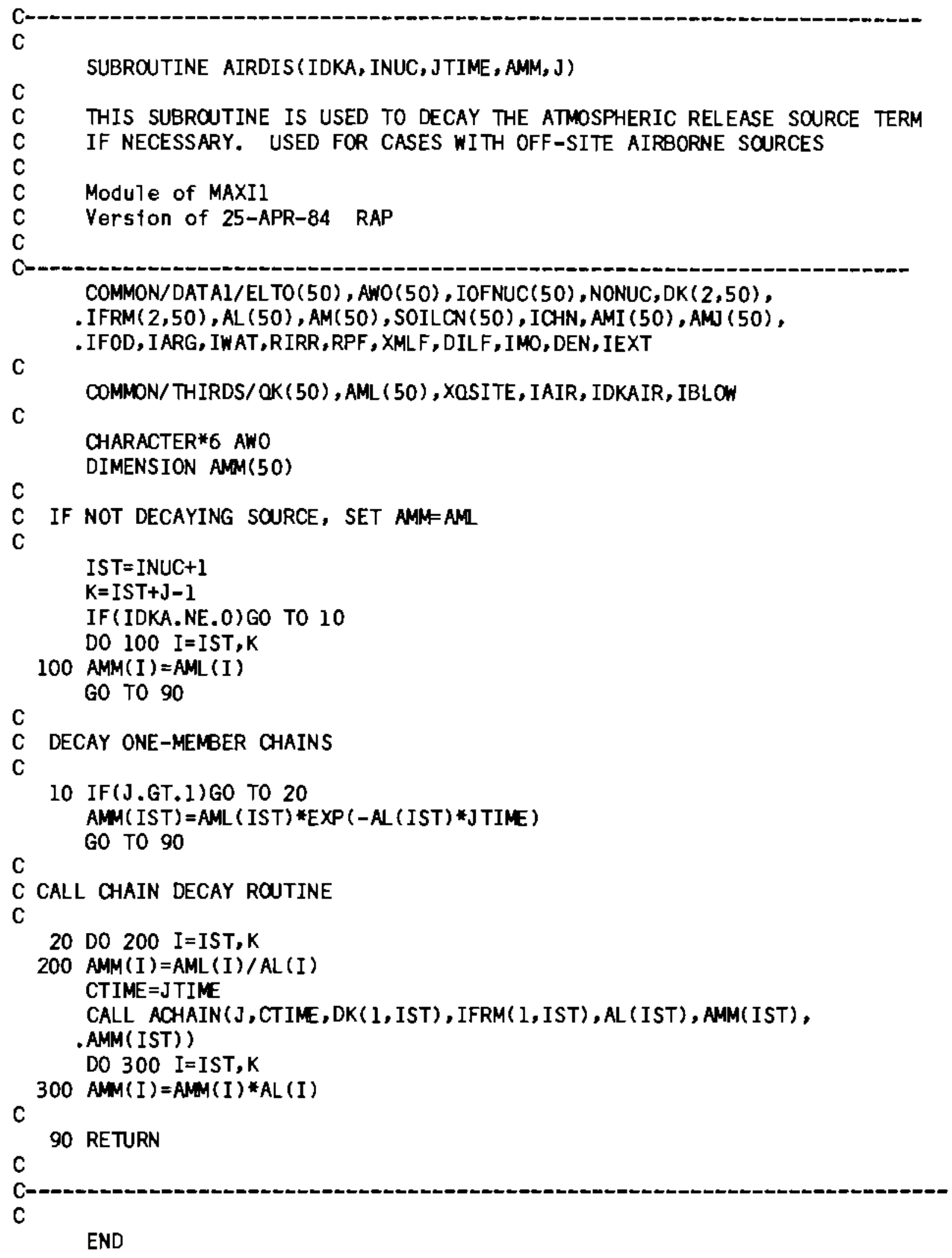


APPENDIX A COMPUTER CODE LISTING - MAXII




APPENDIX A COMPUTER CODE LISTING - MAXII

C CALCULATE TOTAL INHALATION'DOSE SUMMED OVER ALL NUCLIDES

C

ADADOS (ITIME, IORG) = ADADOS( ITIME, IORG) +DADOS (ITIME, INUC, IORG)

C

C CALCULATE TOTAL AOUEOUS FOOD DOSES

$\mathrm{C}$

$$
\begin{aligned}
\text { AARDOS ( ITIME, IORG) } & \text { AARDOS ( ITIME, IORG) } \\
& \text { +ARDOS (ITIME, INUC, IORG) }
\end{aligned}
$$

C

$\mathrm{C}$

$\mathrm{C}$

ADWDOS ( I TIME, IORG) $=$ ADWDOS ( ITIME, IORG)

$\mathrm{C}$

C Calculate pathway totals for each organ, nuclide, and time

$\mathrm{C}$

$\mathrm{C}$

C PRINT 8888, PATHOT (ITIME, INUC, IORG)

C 8888 FORMAT (' PATHOT: ',EIO.2)

$\mathrm{C}$ 300 CONTINUE

$\mathrm{C}$ 200 CONTINUE

C CALCULATE ANNUAL DOSES

$\mathrm{C}$

DO 400 IORG $=1$, NORG

ADOS (ITIME, IORG) = AFDOS( ITIME, IORG) + ADADOS( ITIME, IORG) + AEXDOS( ITIME

C )+AARDOS( ITIME, IORG) + ADWDOS (ITIME, IORG)

400 CONTINUE

100 CONTINUE

$\mathrm{C}$

C DEBUG PRINT STATEMENT--

C ITIME $=0$

C DO 101 JTIME $=$ IT1, IT2

C ITIME $=$ ITIME +1

C PRINT 8881, JTIME, ( ADOS( ITIME, IORG), IORG=1, NORG)

C 8881 FORMAT( ' JTIME, ADOS: ', I4,5E10.3)

C $10 I$ CONTINUE

$\mathrm{C}$

RETURN

$\mathrm{C}$

C

END 
APPENDIX A COMPUTER CODE LISTING - MAXII

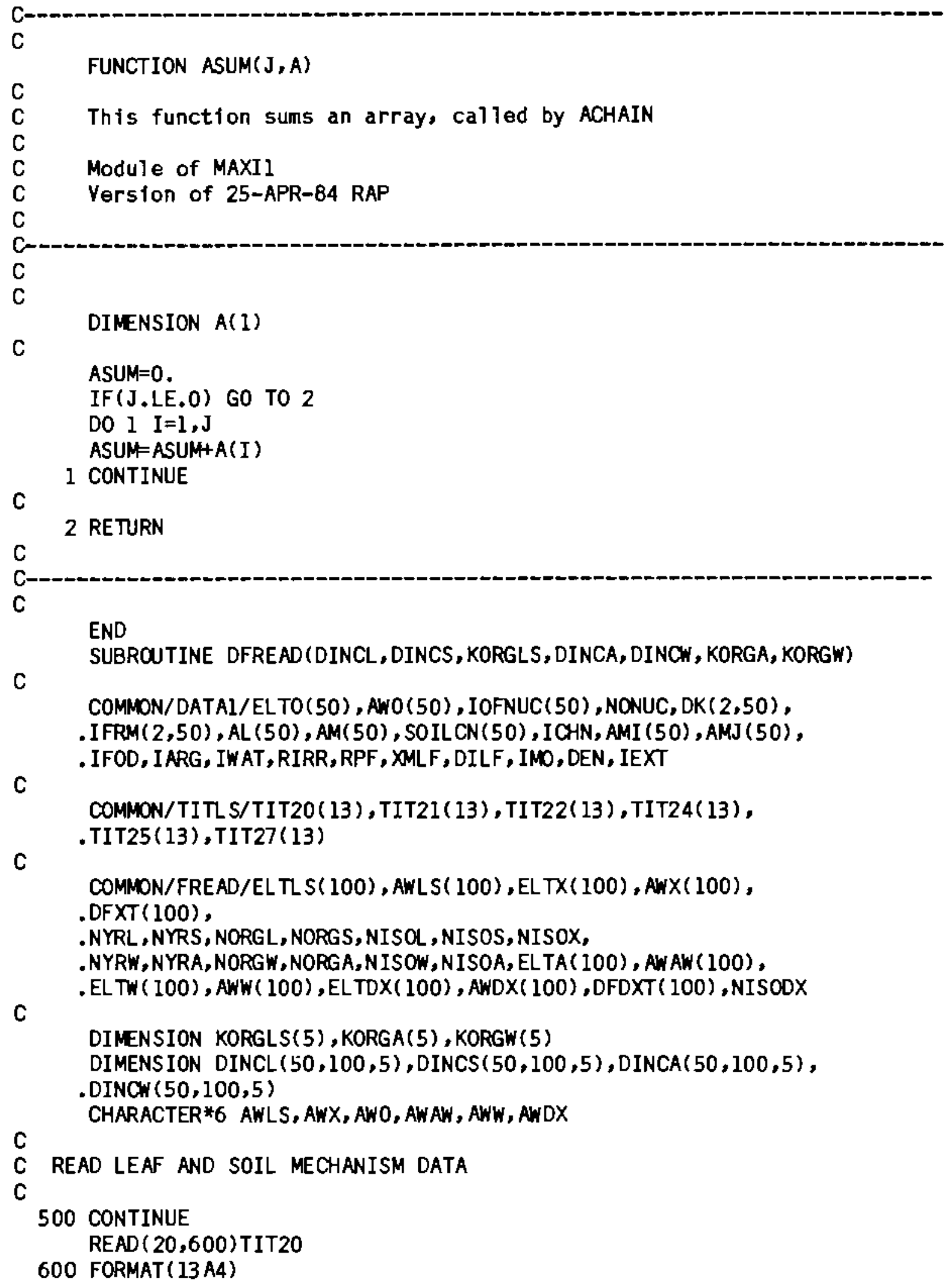

C

COMMON/FREAD/ELTLS(100), AWLS(100), ELTX(100), AWX(100), .DFXT(100), . NYRL, NYRS, NORGL, NORGS, NISOL, NISOS, NISOX, .NYRW, NYRA, NORGW, NORGA, NISOW, NISOA, ELTA(100), AW AW(100),

C . EL TW (100), AWW(100), ELTDX(100), AWDX(100), DFDXT (100), NISODX 
APPENDIX A COMPUTER CODE LISTING - MAXII

READ $(20,1)$ ID, NYRL, NISOL, NORGL

$\operatorname{READ}(20,7)$ (KORGLS(I), I=1, NORGL)

READ $(21,600)$ TIT21

READ $(21,1)$ ID, NYRS, NISOS, NORGS

$\operatorname{READ}(21,7)$ (KORGLS(I), I=1,NORGS)

1 FORMAT $(5 X, A 4,3 I 5)$

7 FORMAT (5I5)

READ $(24,600)$ TIT24

READ (24,1) ID,NYRA,NISOA,NORGA

$\operatorname{READ}(24,7)(\operatorname{KORGA}(\mathrm{I}), \mathrm{I}=1$, NORGA)

READ $(25,600)$ TIT25

$\operatorname{READ}(25,1)$ ID, NYRW, NISOW, NORGW

$\operatorname{READ}(25,7)(K O R G W(I), I=1, N O R G W)$

C

51 CONTINUE

C LEAF, SOIL, AOUEOUS FOOD AND DRINKING WATER DATA IN BLOCKS

C

DO 15 IYR=1, NYRL

IF (IFOD.EQ.0) GO TO 56

$\operatorname{READ}(20,25)$

$\operatorname{READ}(21,25)$

56 IF(IARG.EO.0) GO TO 57

READ $(24,25)$

57 IF(IWAT.EQ.0) GO TO 58

$\operatorname{READ}(25,25)$

58 CONTINUE

25 FORMAT( $1 X)$

DO 10 ISO $=1$, NISOS

IF(IFOD.EQ.0)GO TO 60

READ ( 20,2) EL TLS( ISO), AWLS( ISO), (DINCL (IYR, ISO, IOR), IOR=1, NORGL)

READ (2l, 2) ELTLS(ISO), AWLS(ISO), (DINCS (IYR, ISO, IOR), IOR=1, NORGS)

10 CONTINUE

60 IF(IARG. EO.0) GO TO 61

DO 11 ISO $=1$, NISOA

READ $(24,2)$ ELTA(ISO), AWAW (ISO), (DINCA (IYR, ISO, IOR), . IOR $=1$, NORGA)

11 CONTINUE

61 IF (IWAT.EQ.0) GO TO 15

DO 12 ISO=1,NISOW

READ $(25,2)$ ELTW (ISO), AWW (ISO), (DINCW (I YR, ISO, IOR), . IOR=1, NORGW)

2 FORMAT(A2, A6, 5E12.2)

12 CONTINUE

$\mathrm{C}$

15 CONTINUE

C READ EXTERNAL EXPOSURE MECHANISM DATA

C

READ (22,600)TIT22

READ (22,3) ID, NISOX

3 FORMAT $(5 X, A 4,115)$ 
APPENDIX A COMPUTER CODE LISTING - MAXII

DO 20 ISO $=1$, NISOX

$20 \operatorname{READ}(22,4) \mathrm{ELTX}$ (ISO), AWX(ISO), DFXT(ISO)

IF (IEXT.NE.1) GO TO 31

READ $(27,600) T I T 27$

$\operatorname{READ}(27,3)$ ID,NISODX

DO 30 ISO $=1$, NISODX

READ ( 27,5$)$ ELTDX(ISO), AWDX(ISO), DFDXT(ISO)

30 CONTINUE

31 CONTINUE.

4 FORMAT $(A 2, A 6, E 7.1)$

C

5 FORMAT (A2, A6, E7.1)

C PRINT DIAGNOSTIC MESSAGES, IF ANY, AND STOP

C

IF (NISOL.GT.100.OR.NISOS,GT.100.OR.NISOX.GT. 100)

.GO TO 100

IF(NISOA.GT.100.OR.NISOW.GT.100) GO TO 100

IF (NYRL,GT.50.OR.NYRS.GT.50.OR.NYRA.GT,50.OR.NYRW.GT.50)

.GO TO 200

IF (NORGL , GT , 5 . OR. NORGS, GT . 5. OR. NORGA. GT, 5 . OR. NORGW.GT, 5)

.GO TO 300

RETURN

C

100 PRINT 101 , NISOL, NISOS, NISOX, NISOA, NISOW

GO TO 400

200 PRINT 201 , NYRL, NYRS, NYRA, NYRW

GO TO 400

300 PRINT 301, NORGL, NORGS, NORGA, NORGW

400 STOP

101 FORMAT(1H1,' DIAGNOSTIC 8: NUMBER OF ISOTOPES FOR DFREAD OUT OF BO UNDS', $/, 5(5 X, I 5))$

201 FORMAT ( $1 \mathrm{HL},+$ DIAGNOSTIC 9: NUMBER OF YEARS FOR DFREAD OUT OF BOUND .S',, $4(5 X, 15)\}$

301 FORMAT(IHI,' DIAGNOSTIC 10:NUMBER OF ORGANS OUT OF BOUNDS FOR DFRE. .AD',, $4(5 X, 15))$

END 
APPENDIX A COMPUTER CODE LISTING - MAXII

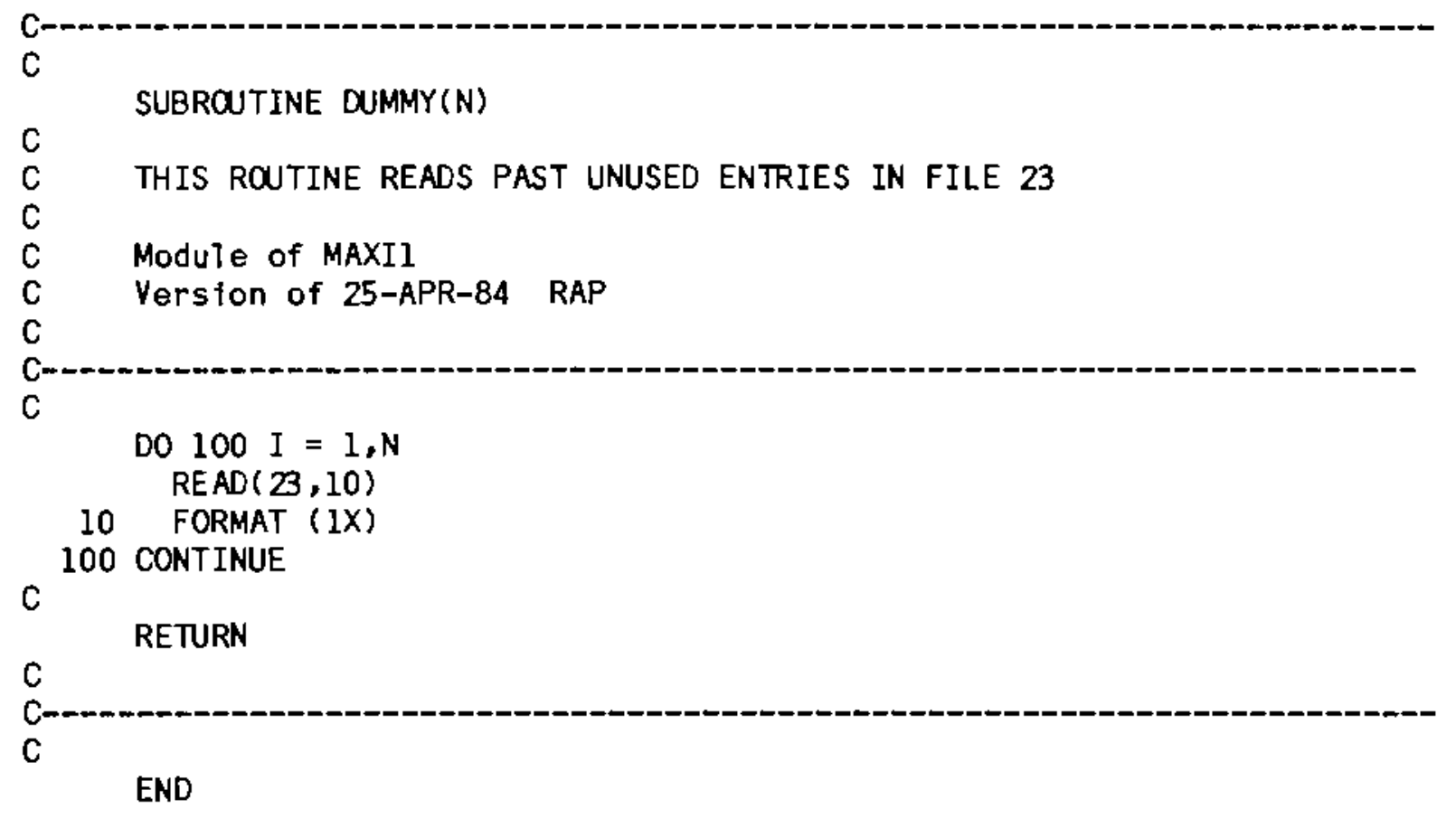


APPENDIX A COMPUTER CODE LISTING - MAXII

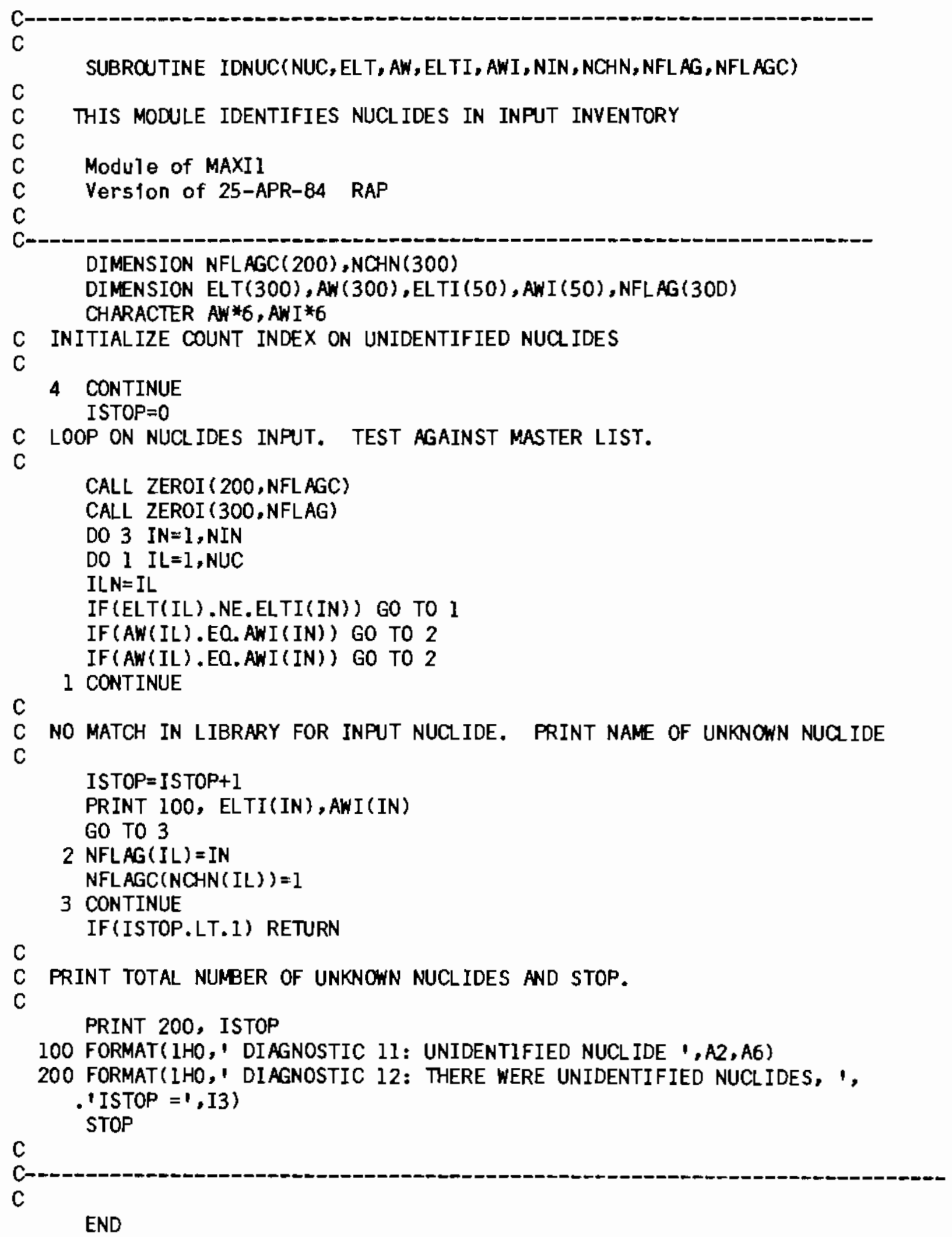


APPENDIX A COMPUTER CODE LISTING - MAXII

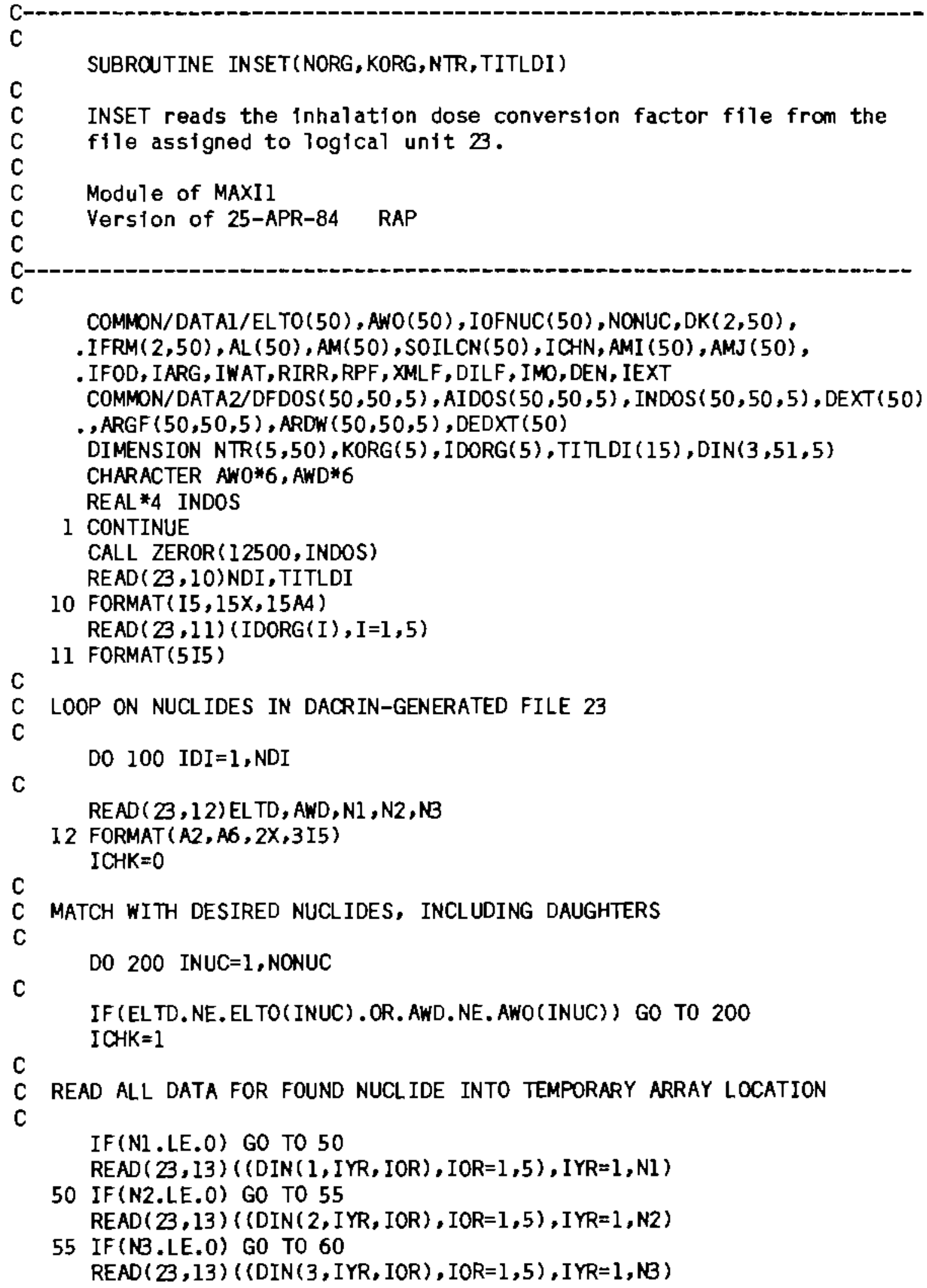


APPENDIX A COMPUTER CODE LISTING - MAXII

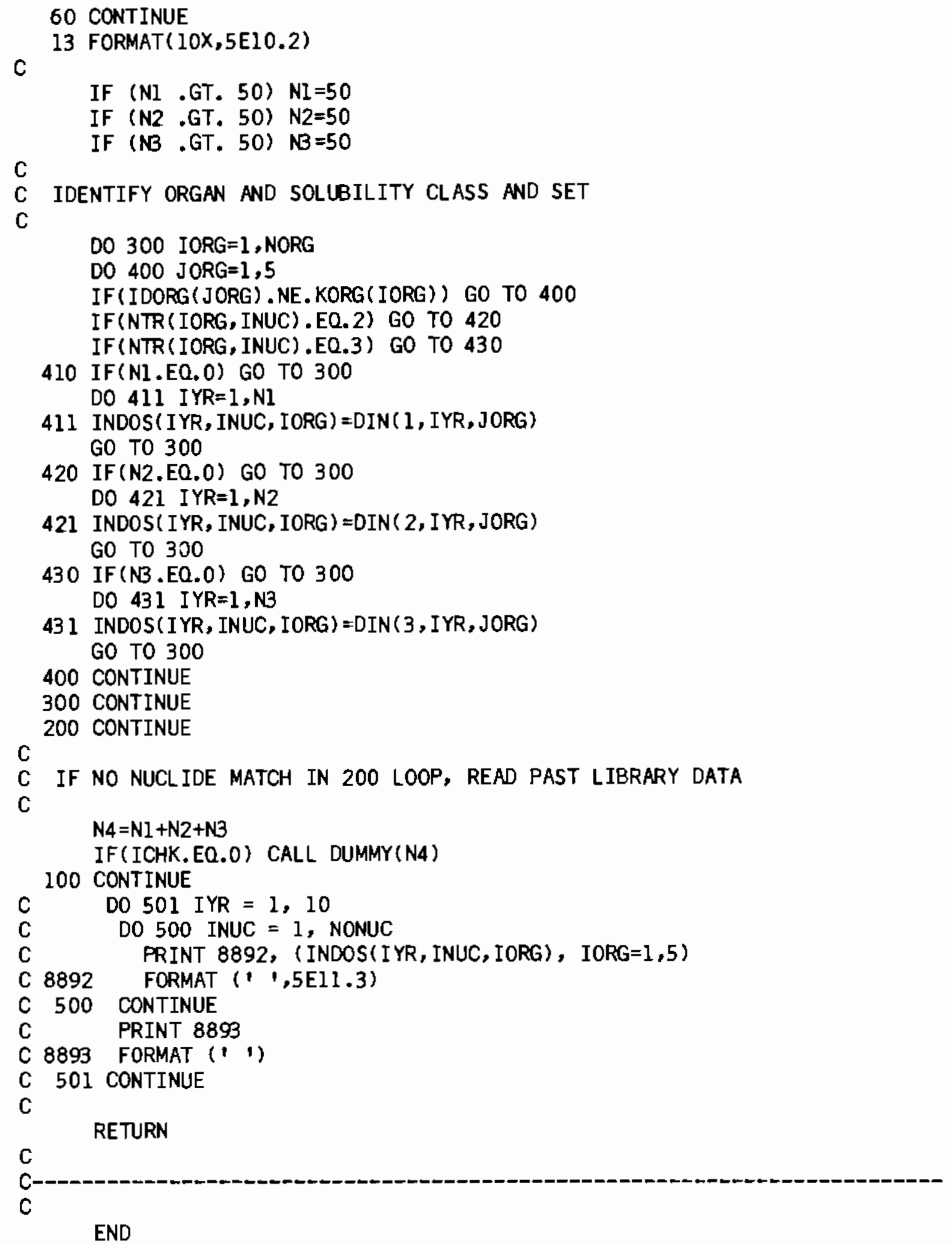









\section{APPENDIX A COMPUTER CODE LISTING - MAXII}

C

60 CONTINUE

DO 210 INUC $=1$, NONUC

IF (PATHOT(ITIME, INUC, IORG) .GT. MAXPTH(INUC, IORG) ) THEN

MAXPTH (INUC, IORG) = PATHOT (ITIME, INUC, IORG)

MAXPM(INUC, IORG) = ITIME

ENDIF

210 CONTINUE

C

2DO CONTINUE

100 CONTINUE

RETURN

C

C

END 
APPENDIX A COMPUTER CODE LISTING - MAXII

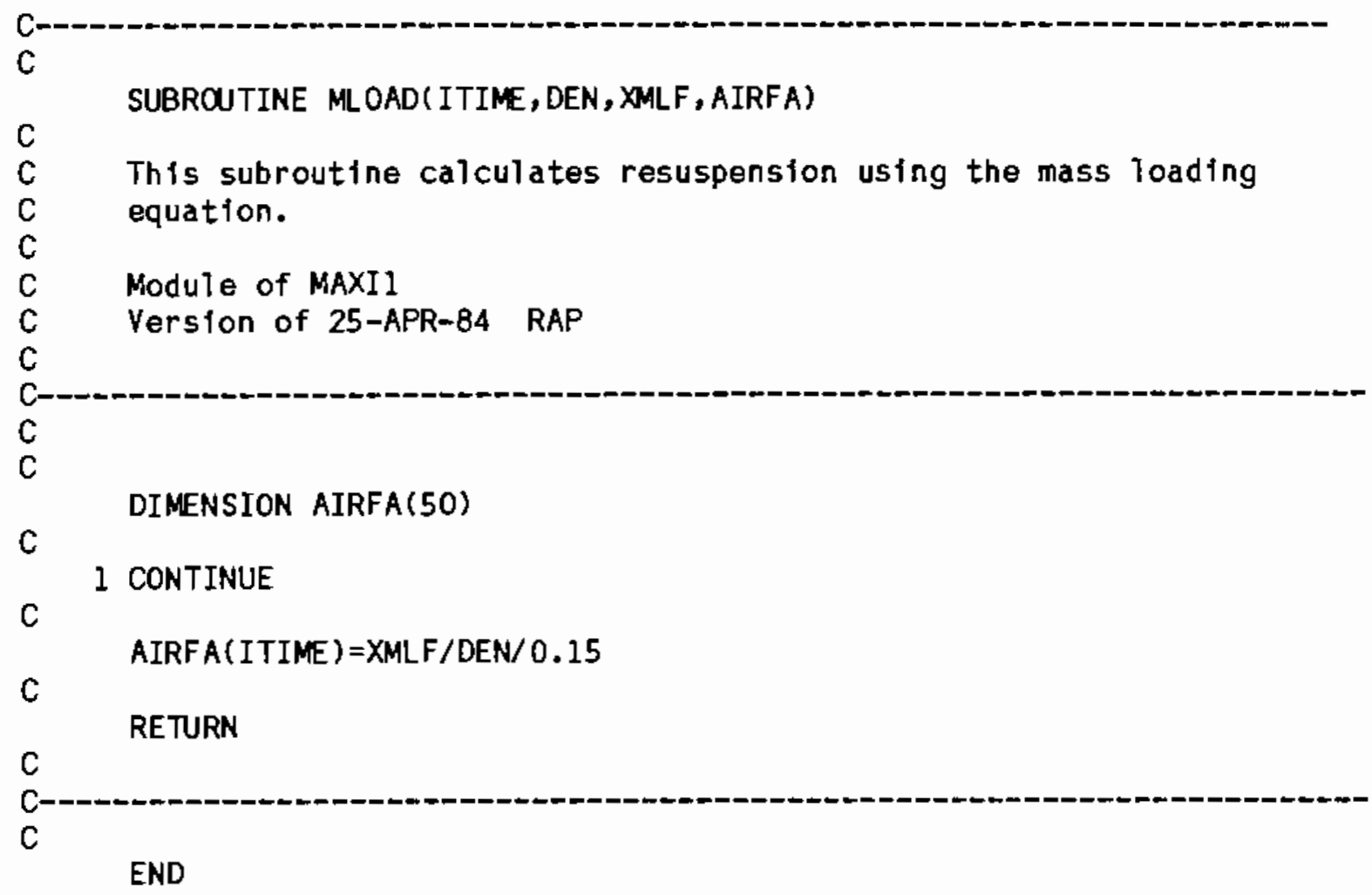


APPENDIX A COMPUTER CODE LISTING - MAXI1

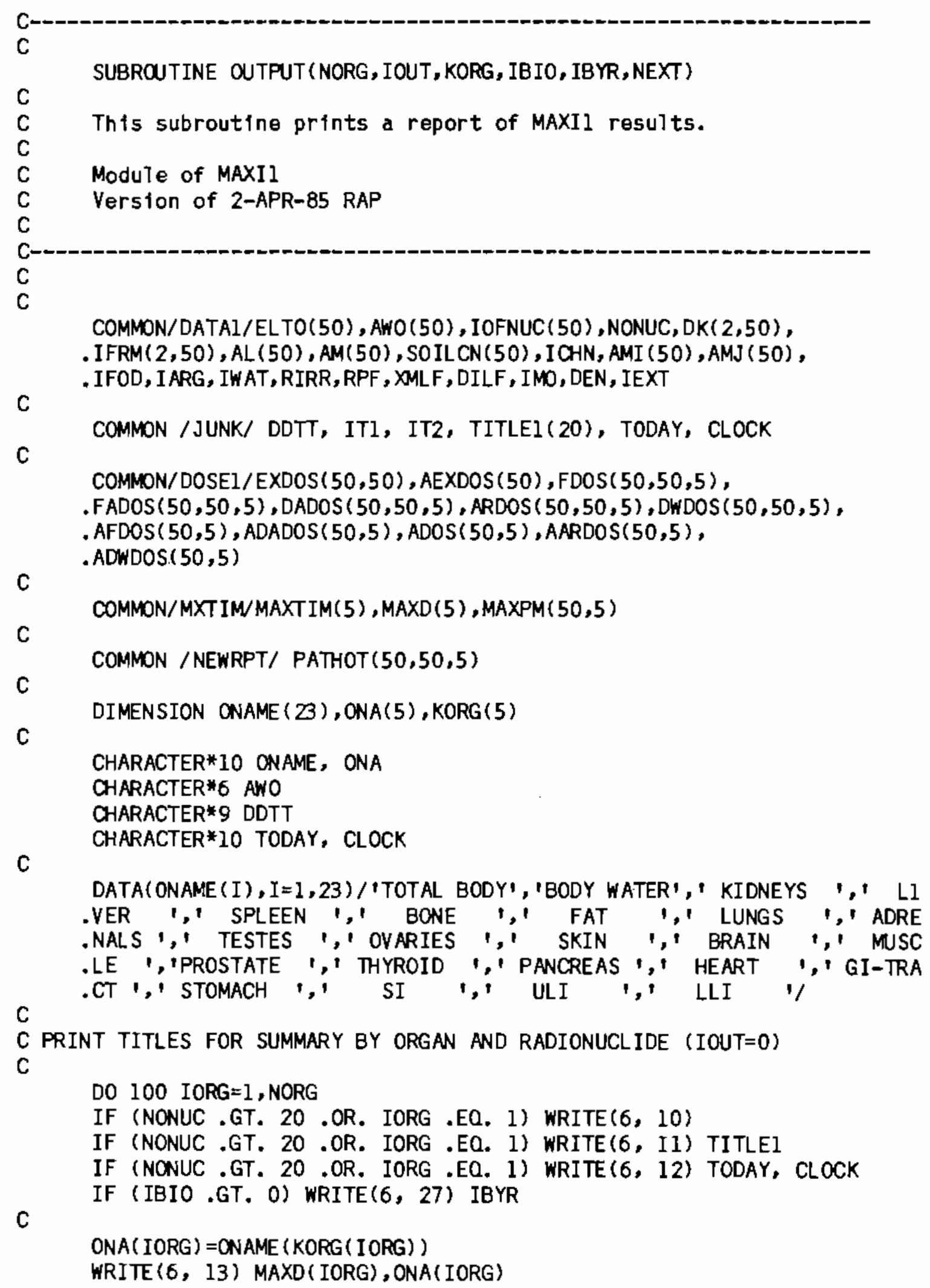


APPENDIX A COMPUTER CODE LISTING - MAXII

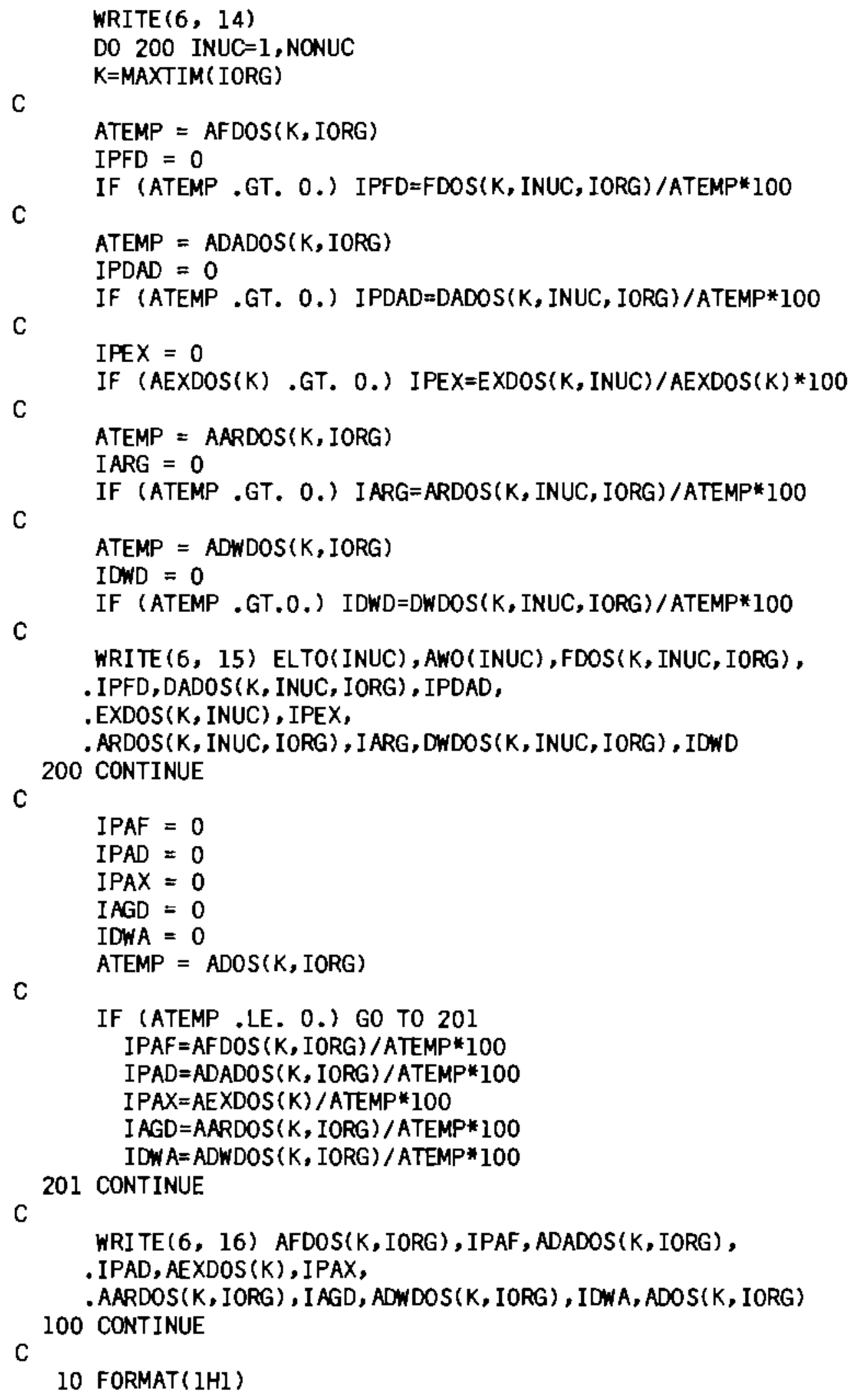


APPENDIX A COMPUTER CODE LISTING - MAXIl

11 FORMAT $(4 X, 20 A 4)$

C

12 FORMAT( $/, 25 X$, 'MAXI, Version VAX2.2 2-APR-85',

' ' executed on ',AlO,' at ',AlO,'.')

C

13 FORMAT $(/, 1 X, 1$ MAXIMUM ANNUAL DOSE SUMMARY FOR THE YEAR', . I5, ' FOR', AlO)

14 FORMAT(//,28X, 'EXPOSURE PATHWAY',/,17X, 'INGESTION',11X, ' 'INHALATION', 1OX, 'EXTERNAL',

$.12 X, '$ AOUATIC FOOD', $8 X$, 'DRINKING WATER',

.$/, 1 X$, 'RADIONUCLIDE', $3 X$,

$.5(1$ REM $1,9 x, 1 \% 1,5 X), 1,1 x, 12(1-1), 3 x, 5(16(1-1), 4 X), /)$

15 FORMAT $(3 X, A 2, A 6,5 X, 5(1 P E 9.2 E 2,2 X, I 4,5 X))$

16 FORMAT ( $1 X, 112(1-1), /, 5 X$, 'TOTALS',6X, 'INGESTION', $4 X, 1 \%$ ', $.6 \mathrm{X}$, ' INHAL ATION ', 4X, ' $\%$ ' ; 6X, 'EXTERNAL', 5X, ' $\%$ ',

$.6 X, 1$ AOUATIC FOOD',1X, $1 \% 1,5 X$, 'DRINKING WATER', $1 X$,

. '1\%',6X,' TOTAL',

$. / 1,16 X, 5$ (1PE9.2E2,2X, I4,5X),1PE9.2E2)

27 FDRMAT ( $1 X$, 'DOSE RESULTING FROM CONCENTRATIONS AT YEAR 1, I5, . OF BIOPORT SIMULATION. ')

C

C

C PRINT DOSE BY ORGAN TO FILES FOR PLOTTING IF BIOPORT INPUT

$\mathrm{C}$

IF (IBIO ,EQ. 1) THEN

C

C

$$
\mathrm{IU}=\mathbf{4 0}
$$

C

C

IF (NEXT .EQ. 1) THEN

WRITE (IU,31) TITLEI, (ONA(IORG), IORG $=1$, NORG) ENDIF

WRITE (IU,32) IBYR, (ADOS(MAXTIM(IORG), IORG), IORG=1, NORG)

ENDIF

C

31 FORMAT (' ',20A4,//,1X, 'Year $1,5(2 \mathrm{X}, \mathrm{A10}) /$

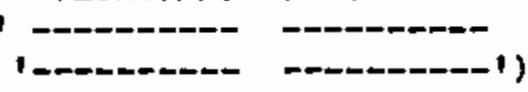

C

32 FORMAT (' $1, I 10,5(2 X, E 10.3))$

$\mathrm{C}$

$\mathrm{C}$

C PRINT MAXIMUM DOSE BY ALL PATHWAYS FOR EACH YEAR AND ORGAN REPORT IF (IOUT .EQ. 4) THEN

WRITE $(6,10)$

WRITE $(6,12)$ TODAY, CLOCK

WRITE (6, 33) TITLE1, (ONA(IORG), IORG=1, NORG)

C 


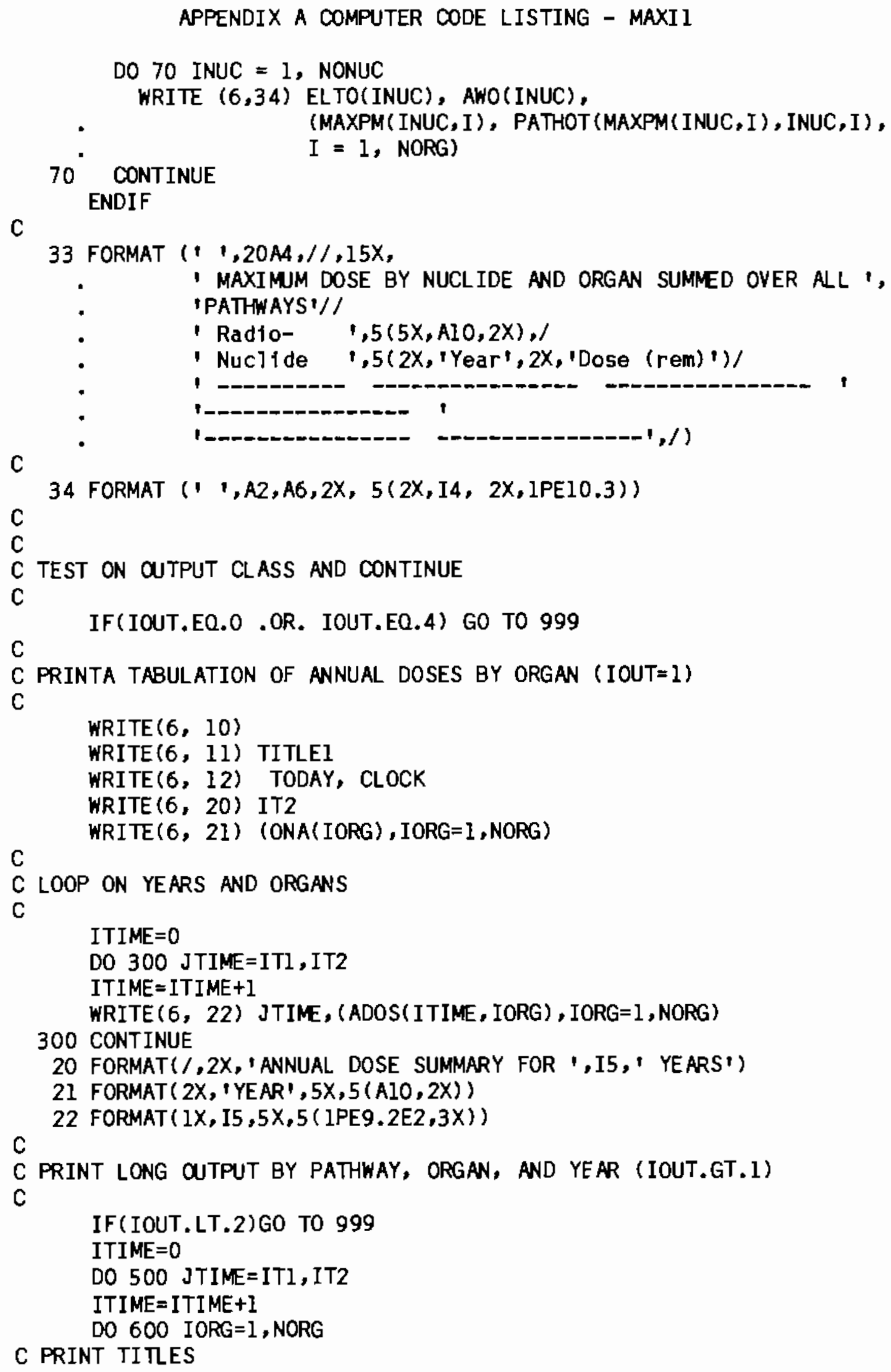


APPENDIX A COMPUTER CODE LISTING - MAXII

WRITE $(6,10)$

WRITE $(6,11)$ TITLEI

WRITE $(6,12)$ TODAY, CLOCK

WRITE $(6,25)$ JTIME, ONA (IORG)

WRITE $(6,14)$

C

C LOOP ON RADIONUCLIDES

C

DO 700 INUC $=1$, NONUC

C

ATEMP $=$ AFDOS (ITIME, IORG)

$I P F D=0$

C

IF (ATEMP .GT. 0.) IPFD=FDOS(ITIME, INUC, IORG)/ATEMP*100

ATEMP: ADADOS( ITIME, IORG)

IPDAD $=0$

IF (ATEMP .GT. 0.) IPDAD=DADOS (ITIME, INUC, IORG)/ATEMP* 100

C

ATEMP $=$ AEXDOS (ITIME)

IPEX $=0$

C

IF (ATEMP . GT. 0.) IPEX $=$ EXDOS(ITIME, INUC) $/$ ATEMP* 100

ATEMP = AARDOS (ITIME, IORG)

$I A R G=0$

IF (ATEMP .GT. 0.) I ARG $=$ ARDOS(ITIME, INUC, IORG) $/$ ATEMP* $^{*} 100$

C

ATEMP $=$ ADWDOS (ITIME, IORG)

$I D W D=0$

IF (ATEMP . GT. 0.) IDWD=DWDOS(ITIME, INUC, IORG)/ATEMP* 100

C

WRITE(6, I5) ELTO(INUC), AWO(INUC), FDOS(ITIME, INUC, IORG), . IPFD, DADOS ( ITIME, INUC, IORG),

. IPDAD, EXDOS (ITIME, INUC), IPEX,

C

. ARDOS( ITIME, INUC, IORG), I ARG, DWDOS ( ITIME, INUC, IORG), IDWD

C

700 CONTINUE

IPAF $=0$

IPAD $=0$

IPAX $=0$

IAGD $=0$

IDWA $=0$

ATEMP = ADOS (ITIME, IORG)

C

IF (ATEMP .LE. 0.) GO TO 701

IPAF $=$ AFDOS (ITIME, IORG $) /$ ATEMP $* 100$

IPAD $=A D A D O S$ ( ITIME, IORG) $/$ ATEMP* 100

IPAX $=A E X D O S$ (ITIME) $/$ ATEMP $* 100$

I $A G D=A A R D O S$ ( ITIME, IORG) $/ A T E M P * 100$

IDW $A=A D W D O S$ ( ITIME, IORG) / ATEMP* 100 
APPENDIX A COMPUTER CODE LISTING - MAXII

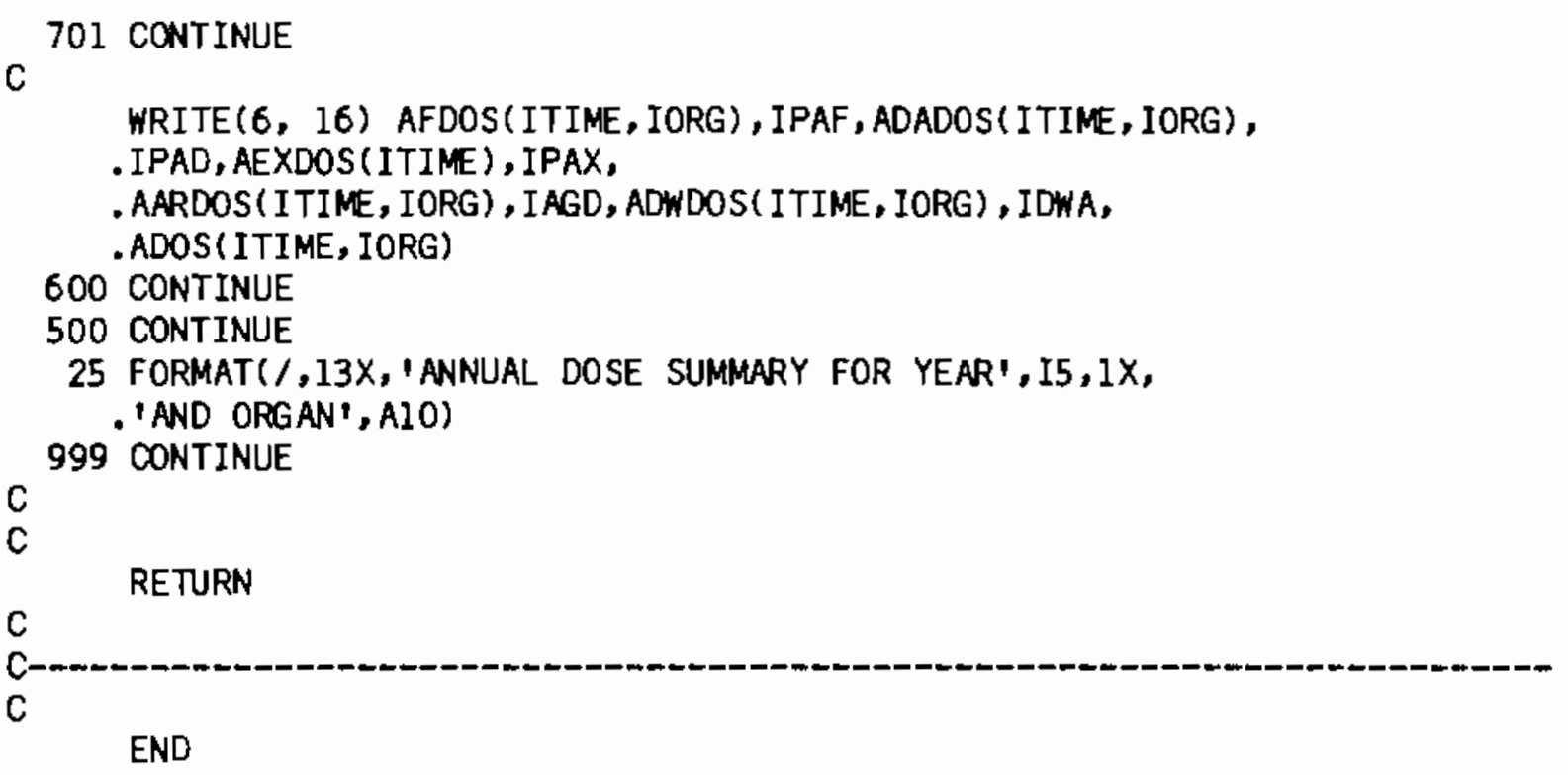




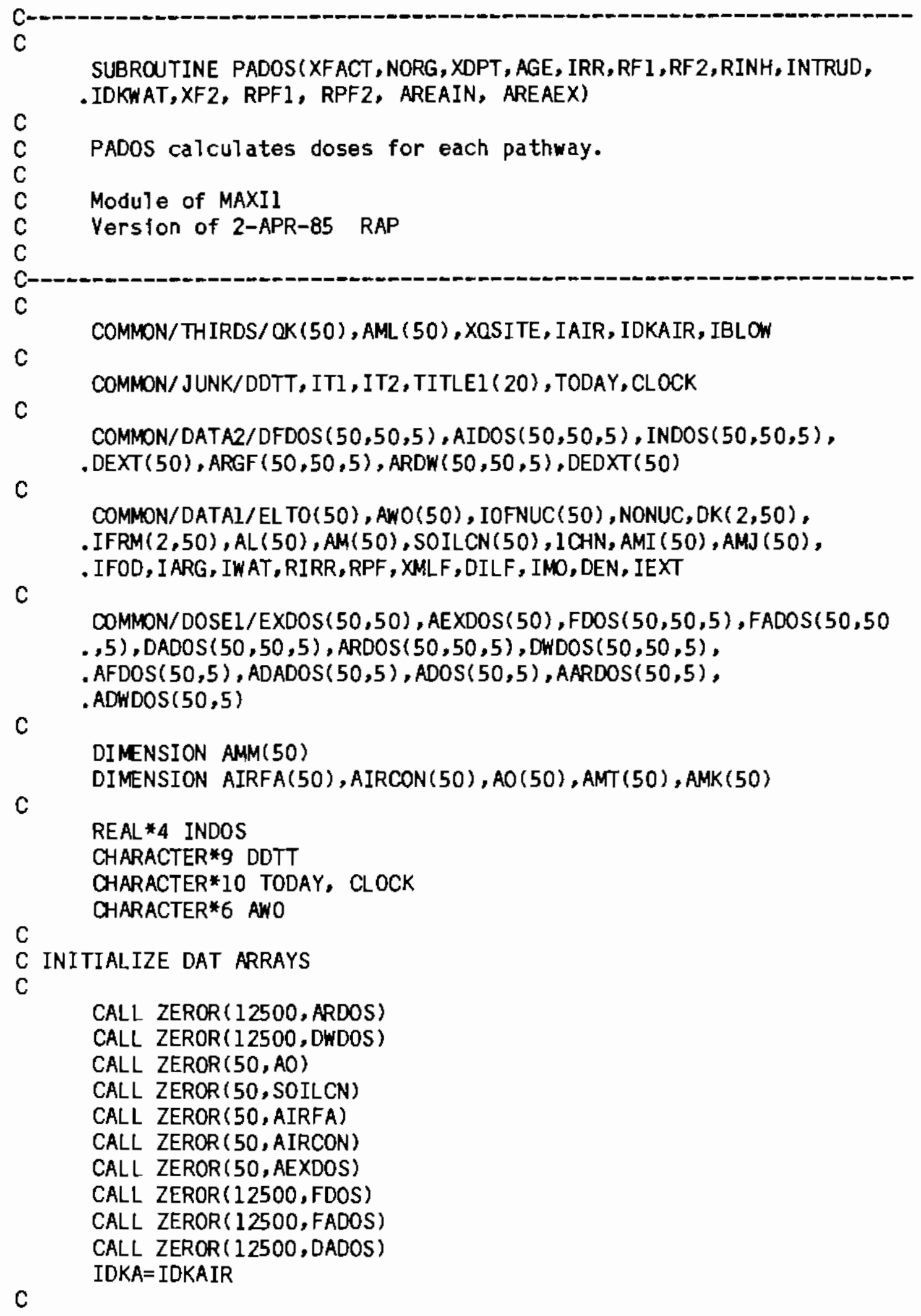

CALL ZEROR (12500,ARDOS)

CALL ZEROR(12500,DWDOS)

CALL ZEROR $(50, A 0)$

CALL ZEROR (50,SOILCN)

CALL ZEROR (50,AIRFA)

CALL ZEROR (50,AIRCON)

CALL ZEROR (50,AEXDOS)

CALL ZEROR(12500, FDOS)

CALL ZEROR( 12500 ,FADOS)

CALL ZEROR ( 12500, DADOS)

C IDKA= IDKAIR 
APPENDIX A COMPUTER CODE LISTING - MAXII

C MASTER LOOP ON TIME

$\mathrm{C}$

$$
\begin{aligned}
& \text { ITIM2 }=0 \\
& \text { ITA=IT1-IBLOW } \\
& \text { ITW=ITl-IRR } \\
& \text { ITIME }=-M A X(\text { IRR, IBLOW })
\end{aligned}
$$

ITM=ITI+ITIME

DO 50 JTIME $=$ ITM, IT2

IF (INTRUD. NE. O. AND. JTIME.GT. ITI)GO TO 50

ITIM2 $=$ ITIM $2+1$

ITIME $=$ ITIME+1

$N=I T I M E-1$

IF (ITIM2.EQ.1) AITIME $=$ JTIME

IF (ITIM2.GT. 1) AITIME $=1.0$

BITIME $=J$ TIME + AGE-ITM

C

C CALL RESUSPENSION OR MASS LOADING FACTOR

C

IF (ITIME, LE,O) GO TO 10

IF (AGE.GE.0)

.CALL AFACT(BITIME, AIRFA, ITIME, XDPT)

IF (AGE.LT,O) CALL MLOAD(ITIME,DEN, XMLF,AIRFA)

10 CONTINUE

INUC $=0$

C LOOP ON CHAINS

DO $200 \quad \mathrm{ICH}=1$, ICHN

C

C SET IRRIGATION AND AOUATIC FOOD WATER CONC TO AMK

C ONCE, IF CONSTANT SOURCE

C EVERY TIME, IF DECAYING SOURCE

C

$J=I O F N U C(I C H)$

IF (JTIME.EO. ITA) CALL AIRDIS( IDKA, INUC, JTIME, AMM, J)

IF (JTIME. EQ. ITW) CALL WATER (IDKWAT, INUC,J TIME, AMK, J)

$\mathrm{C}$

C SET SOIL CONC, DEPENDENT ON IRRIGATION, SUBSURFACE, ETC.

C

CALL SOLCON (ITIM2, ICH, INUC, AITIME, J, AO, JTIME, AMT, ITI , AMK, AMM, RPF 1)

$\mathrm{C}$

IF (IDKA. NE. 0. AND. JTIME, GE. ITA)CALL AIRDIS ( I, INUC, JTIME, AMM, J)

IF (IDKWAT.NE.0.AND.JTIME.GE.ITW)CALL WATER( 1 , INUC,JTIME, AMK, J)

C

DO $290 \mathrm{JNUC}=1, \mathrm{~J}$

C

INUC $=$ INUC+1

IF(JTIME.LT.ITI) GO TO 290

$\mathrm{C}$

C CALCULATE AIR CONCENTRATIONS

$\mathrm{C}$ 


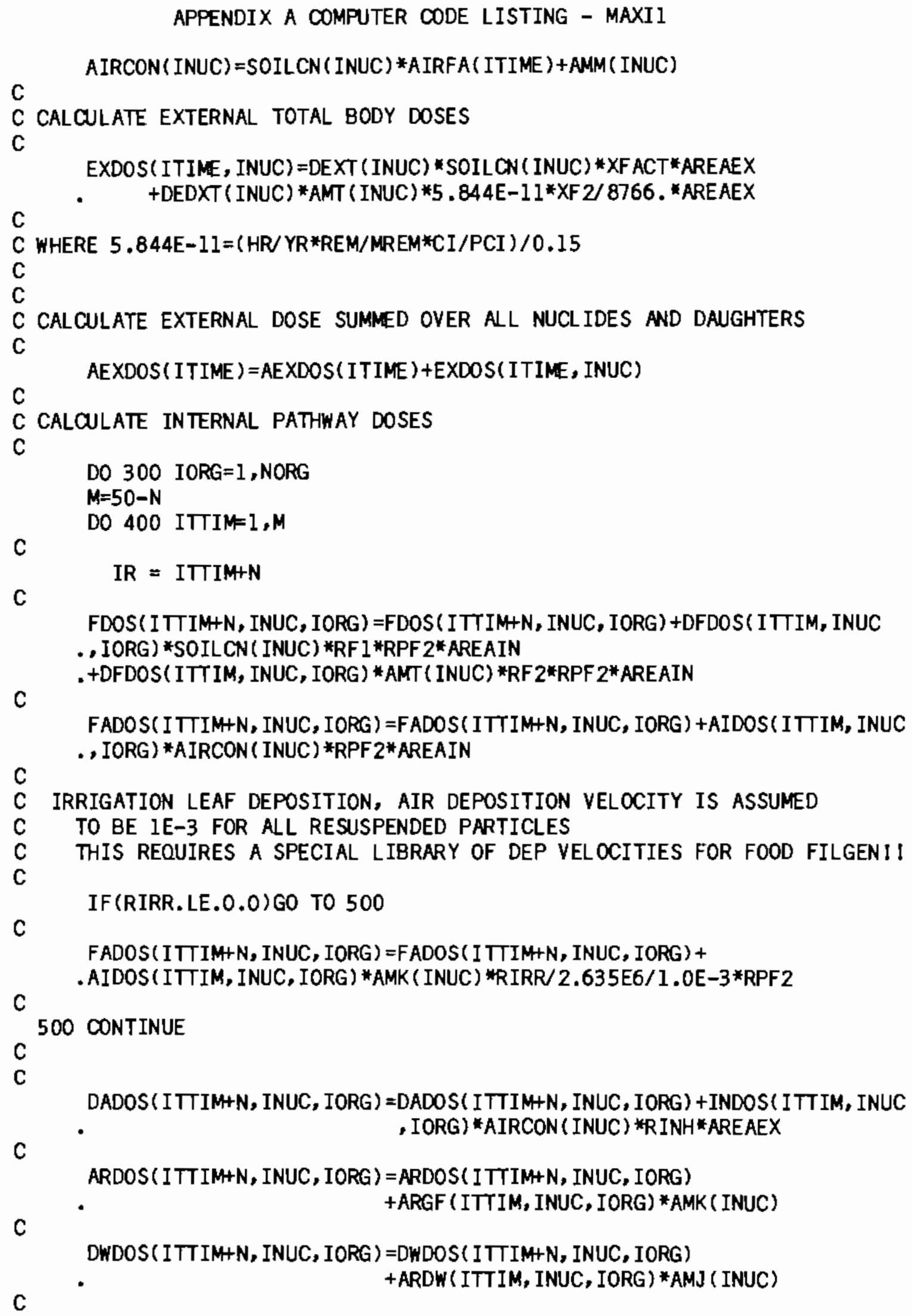


APPENDIX A COMPUTER CODE LISTING - MAXII

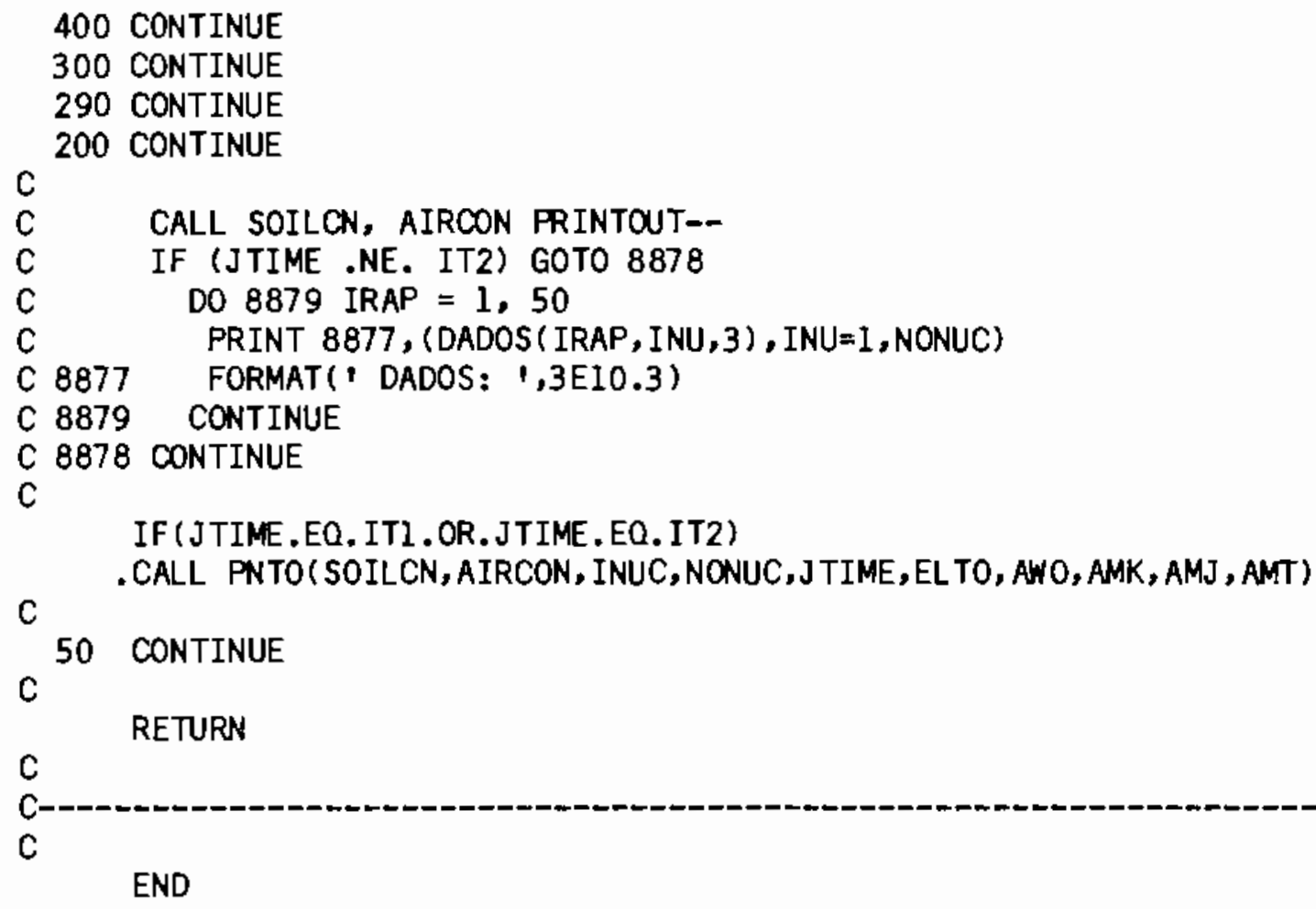


APPENDIX A COMPUTER CODE LISTING - MAXII

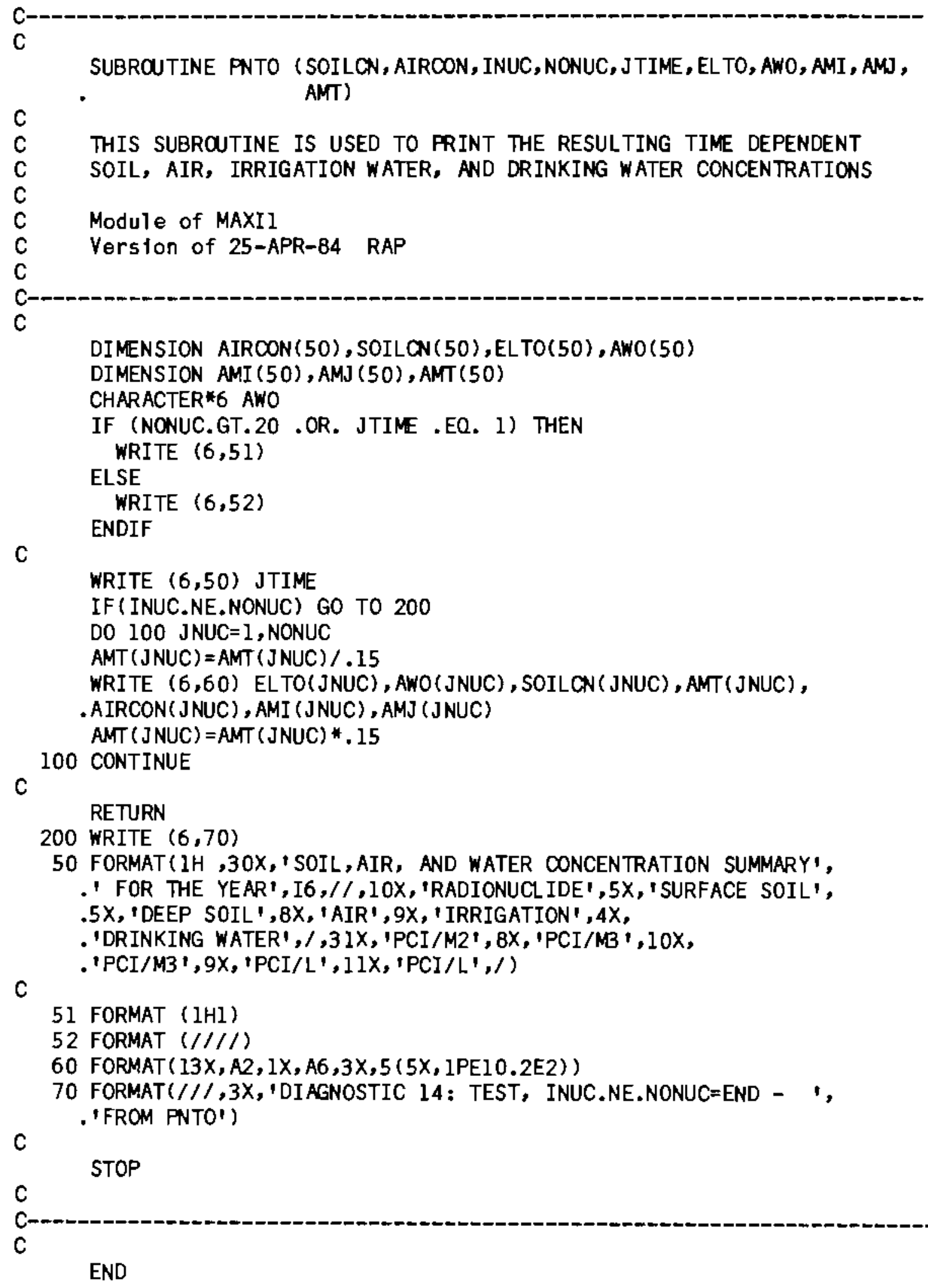


APPENDIX A COMPUTER CODE LISTING - MAXII

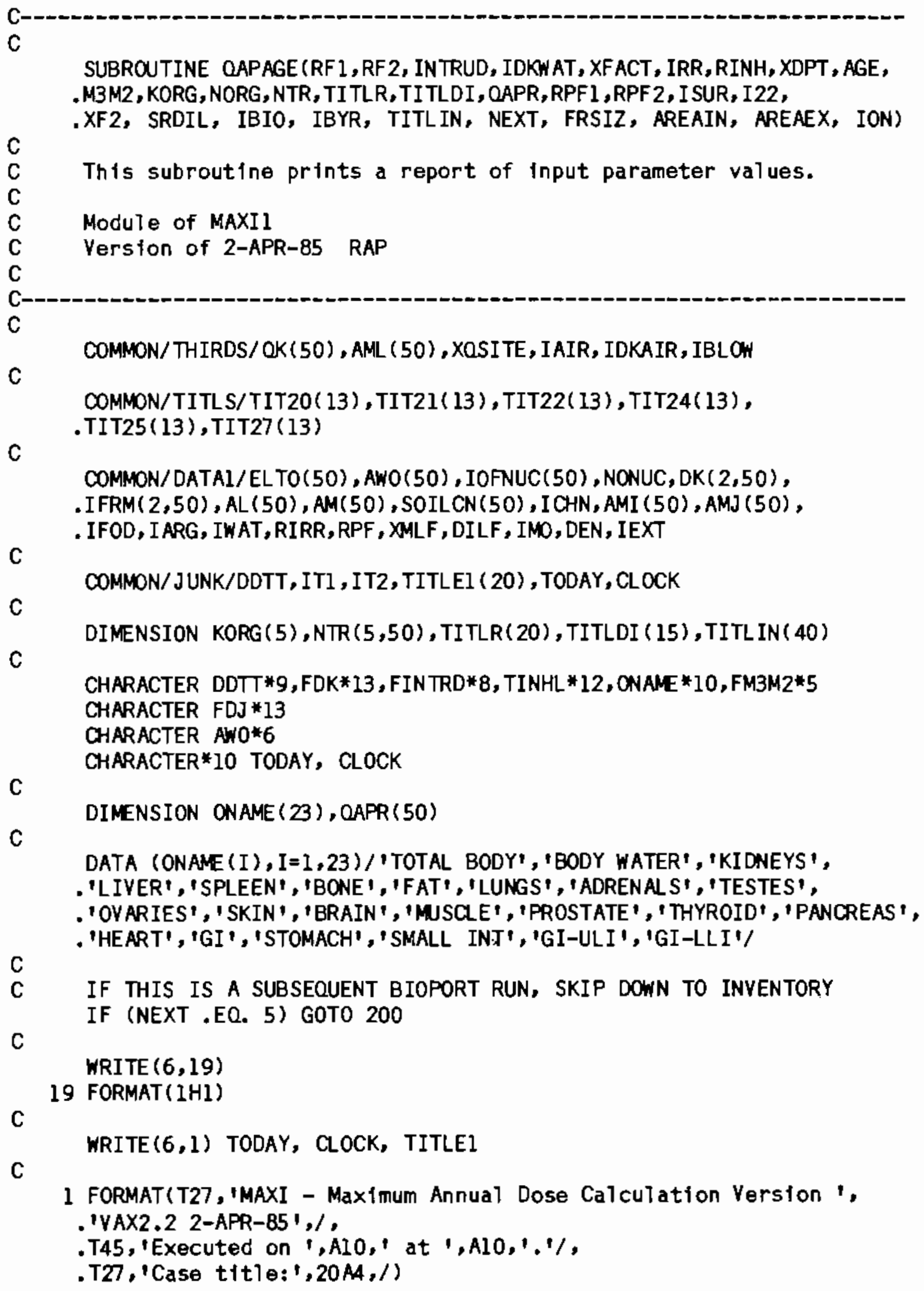




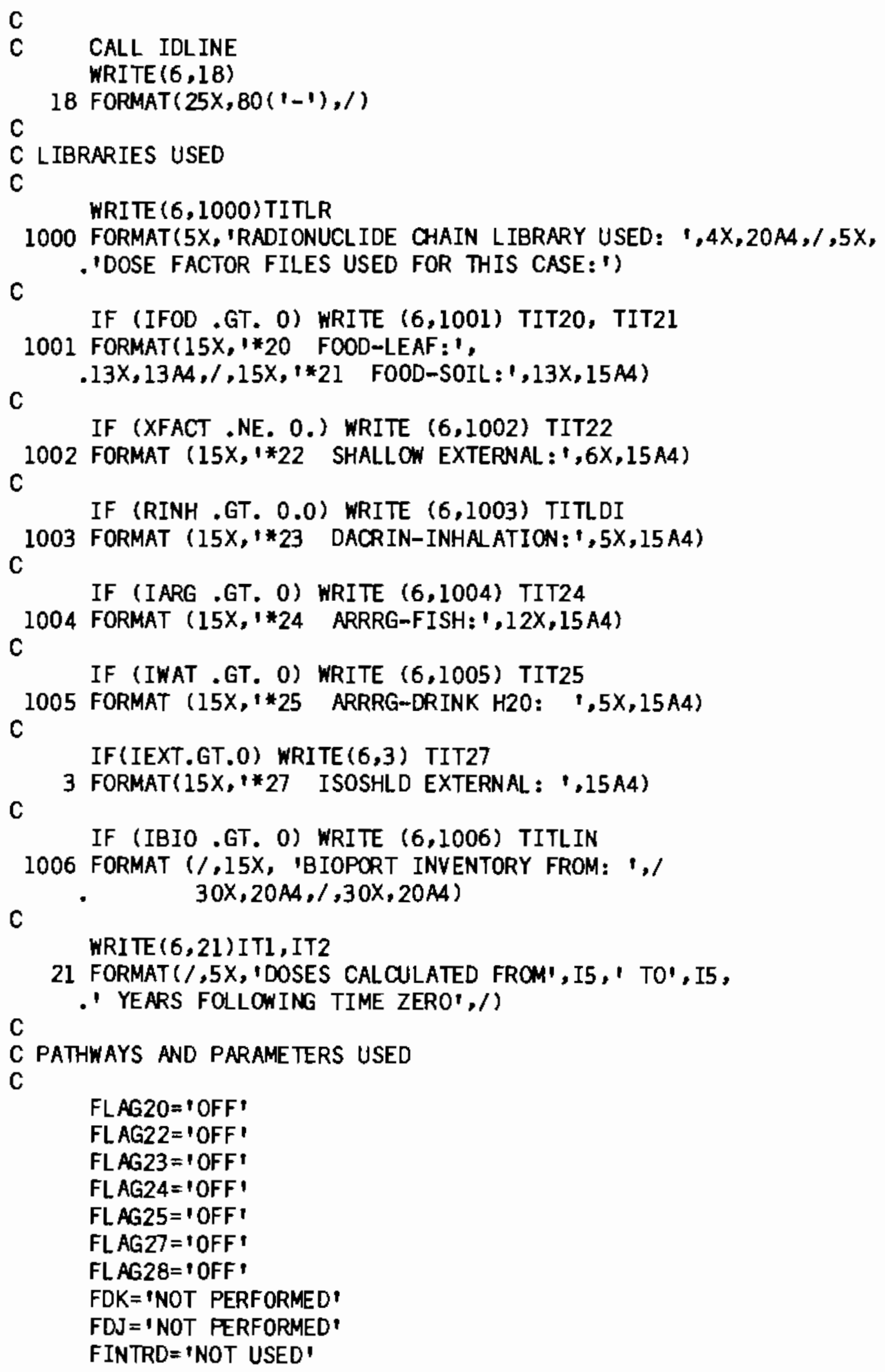


APPENDIX A COMPUTER CODE LISTING - MAXII

IF (IFOD.NE. O) FL AG2O $=1$ ON ,

IF (RINH.NE.0.0) FLAG $23={ }^{\circ} \mathrm{ON}$,

IF (IARG. NE. O) FLAG24 $=1$ ON '

IF (IWAT. NE. O) FLAG25 $=1$ ON '

IF (IEXT.NE, O) FL AG27 $=1$ ON '

IF (XFACT.NE.0.0)FLAG22=I ON '

IF (IAIR, EQ.1) FLAG28 $=1$ ON 1

IF ( INTRUD. NE. O) FINTRD $=$ 'USED

IF (IDKWAT.NE.0) FDK= ' PERFORMED

IF (IDKAIR. EQ.1) FDJ = ' PERFORMED

C

WRITE $(6,4) F L A G 20, F L A G 23, F L A G 24$, SRDIL,FLAG25, FDK, FLAG28,FDJ , .FLAG27, XQSITE, FLAG22, FINTRD

4 FORMAT (5X, 'PATHWAYS INITIALIZED FOR DOSE CALCULATIONS: 1, T65, .'SPECIAL PARAMETERS INITIALIZED: ',/,15X,'FARM PRODUCT INGESTION:',

. $T 51, A 3, /, 15 X, '$ INHALATION OF RESUSPENDED MATERIAL: ' , $A 3, /$

, ,15X, 'AOUATIC FOODS INGESTION: ', T51, A3,

. T70, ' INVENTORY DILUTION FACTOR:' ', 1PE9.2E2,/,

.15X,' DRINKING WATER INGESTION: ', T51, A3, T70, 'DECAY OF RIVER ',

.'RELEASE SOURCE TERM ', Al3,/,

.15X,' CONTINUING ATMOSPHERIC DEPOSITION 'A3,T70, 'DECAY OF ',

- 'a IR RELEASE SOURCE TERM ',Al3,/,

$.15 X, 1$ EXTERNAL FROM BURIED WASTES $1, T 51, A 3$,

.T70,'SITE X/Q: ', IPE9.2E2,/

.15X, 'EXTERNAL FROM SURFACE DEPOSITS: ', T51, A3,T70,

$\mathrm{C}$

' 'SPECIAL INHALATION MODEL ',A8)

IF (ION , GT, 0) WRITE $(6,1055)$ FRSIZ, AREAIN, AREAEX

1055 FORMAT (T70, 'SIZE OF THE SITE:',F9.5,' FRACTIONAL HECTARES'/, .T70, 'INTERNAL PATHWAY AREA CORRECTION FACTOR:' , IPE9.2E2/

.T70, 'EXTERNAL PATHWAY AREA CORRECTION FACTOR:',1PE9.2E2)

$\mathrm{C}$

C FARM PRODUCT PARAMETERS

$\mathrm{C}$

WRITE $(6,5)$ RF 1,RIRR, RF2, IM0, RPF 2, DILF, IRR

5 FORMAT ( $101,4 X, '$ FARM PRODUCT PARAMETERS USED: 1,1 ,

$.15 X$, 'FRACTION OF ROOTS IN UPPER SOIL: ',OPE10.2E2,

.T65, 'IRRIGATION RATE: ', IPE10.2E2, 'L/M**2/MO',/

$.15 X, '$ 'FRACTION OF ROOTS IN BURIED WASTE',OPE9.2E2,

. T65, 'MONTHS PER YEAR IRRIGATED: ',I5,/

.15X,' 'FRACTION OF TOTAL DIET GROWN ON SITE: ',1PE10.2E2,

.T65, 'RIVER DILUTION FACTOR: ', 1PE10.2E2, 'YR/L',/

. T65, 'YEARS OF IRRIGATION WITH CONTAMINATED WATER PRIOR TO',/

C

. T70, 'THE DOSE CALCULATIONS:',15)

C EXTERNAL PATH PARAMTERS

C

IF (FLAG22.EQ.'OFF' AND. FLAG27 .EQ. 'OFF') GO TO 100 WRITE $(6,1060)$

1060 FORMAT ('0',4X,' EXTERNAL EXPOSURE PARAMETERS USED: ' $)$ 
WRITE $(6,1065)$ RPFI

1065 FORMAT (I5X, 'RATIO OF EXTERNAL CONTAMINATION IN SURFACE SOIL ', ' 'TO SUBSURFACE SOIL', IPEIO.2E2)

IF (XF2 .GT. 0.0) WRITE $(6,1070) \times F 2$

1070 FORMAT (15X,'NUMBER OF HOURS OF EXPOSURE TO EXTERNAL ',

$\therefore$ CONTAMINATION', IPEI0.2E2)

IF (XF2 .EQ. 0.0) WRITE $(6,1075)$ XFACT

1075 FORMAT (15X, 'XFACT MODIFICATION: ', IPE10.2E2)

IF (I22 .EQ. 0) WRITE $(6,1080)$

1080 FORMAT(15X, 'SURFACE DEPOSITS DRFS FROM ISOSHLD;'

C

. 'MODIFICATION FACTOR: 5.844E-11')

$\mathrm{C}$

C AIR PATH PARAMETERS

C

IF (FLAG23 .EQ. 'OFF') GO TO 101

C

WRITE $(6,1090)$

1090 FORMAT ('0',4X,' INHALATION PARAMETERS USED: ')

$\mathrm{C}$

RIN $=$ RINH * 8766 .

WRITE $(6,1095)$ RINH,RIN

1095 FORMAT (15X, 'MODIFICATION FACTOR, RINH: ', 1PE10.2E2, $. / 20 X, '$ (EOUIVALENT TO BREATHING RATE OF $230 \mathrm{CC} / \mathrm{SEC}$ FOR ',0PF6.0,

$\mathrm{C}$

. $H R / Y R) '$ )

TINHL $=$ I ANSPAUGH ,

IF (AGE, LT.0.0)TINHL= 'MASS LOADING' WRITE $(6,6)$ TINHL

6 FORMAT(15X, 'RESUSPENSION MODEL USED FOR CALCULATING AIR ', .' CONCENTRATION: ', Al2)

AVCM $=$ XDPT *15.0

IF (AGE.GE,0.0) WRITE $(6,7)$ AGE, AVCM

7 FORMAT (15X, 'AVERAGE AGE OF MATERIAL ON GROUND AT TIME ZERO: ', .1PE10.2E2,' YEARS',1,15X,' TOP 1,OPF4.1,' CM OF THE ',

. 'CONTAMINATED SURFACE LAYER IS AVAILABLE FOR RESUSPENSION.', . IPE $10.2 E 2 / /)$

IF (AGE.LT.0.0)WRITE $(6,8)$ DEN, XMLF

8 FORMAT (15X, 'SOIL DENSITY, G/M**3: ', IPE10.2E2,/,15X,

'MASS LOADING FACTOR, G/M**3:',1PE10.2E2,1/)

101 CONTINUE

C

C ORGANS

$\mathrm{C}$

WRITE $(6,9)$ (ONAME (KORG( $I)), I=1$, NORG)

9 FORMAT(' ',/

$.5 X, 10 R G A N S$ FOR WHICH DOSES ARE CALCULATED (SAME ORDER AS',

$\therefore$ SOLUBILITIES GIVEN BELOW): $1, / /, 10 X, 5(10 X, A I 0))$ 
C

C SIGN-OFF

C WRITE $(6,10)$

10 FORMAT $(/ /, 20 X, '$ INPUT PREPARED BY',25X, 'DATE' $, /, 37 X, 25(l=1), 4 X$, $.10(1=1), / /, 20 X, '$ INPUT CHECKED BY',26X, 'DATE', $/, 37 X, 25(1=1), 4 X$,

C $.10(1=1))$

C RELEASES

C

$I D=' Y R '$

$I D L=I N T(D I L F)$

C IF (IDL .EQ. I) ID = 'L '

$F M 3 M 2=(M * * 2)$,

IF (M3M2. EQ.1)FM3M2 $=I M * * 3)$ '

C IF (M3M2.EQ.2) FM3M2='KG )'

C

200 CONTINUE

IF (IBIO .GT. O) THEN WRITE $(6,1011)$ IBYR

1011 FORMAT ('I INVENTORY FOR YEAR ',I5,' OF BIOPORT SIMULATION.') ELSE

WRITE $(6,1012)$

1012 FORMAT ('I')

ENDIF

C

WRITE $(6,11)$ FM3M2, ID

11 FORMAT $11 \mathrm{H}, 5 \mathrm{X}$, 'RELEASE TERMS ', T56,' SOIL SOURCE',T70, 'IRRIGAT', 'ATION/AOUATIC', T92, 'DRINKING WATER', T110, 'ATM. RELEASE',/, $.10 \mathrm{X}$, 'NUCL IDE', 10X, 'ORGAN SOLUBIL ITY CLASSES' $, 5 \mathrm{X}, 1(\mathrm{PCI} / 1, \mathrm{A5}, 10 \mathrm{X}$,

C ' $(\mathrm{PCI} / 1, \mathrm{A2}, 1) 1,9 \mathrm{X}, 1(\mathrm{PCI} / \mathrm{L}) 1,10 \mathrm{X}, 1(\mathrm{CI} / \mathrm{YR}) 1,1)$

DO $13 \mathrm{I}=1$, NONUC

WRITE $(6,12) \operatorname{ELTO}(I), \operatorname{ANO}(I),(N T R(J, I), J=1,5), \operatorname{OAPR}(I), \operatorname{AMI}(I), A M J(I)$ ,AML (I)

12 FORMAT (10X,A2, IX, A6, 8X,5I4,4(8X, 1PE10,2E2))

$\mathrm{C}$

13 CONTINUE

C NOTE BOX

$\mathrm{C}$

C

IF (NEXT .EQ. 5) GOTO 201

IBOX $=50-$ NONUC

IF (IBOX.LT.6)GO TO 20

WRITE $(6,14)$

14 FORMAT $(/, 20 X, 20(1 * 1)$, IPLEASE NOTE ANY SPECIAL CONSIDERATIONS IN', 'THIS SPACE $1,20(1 * 1))$

$I B X=I B O X-2$ 


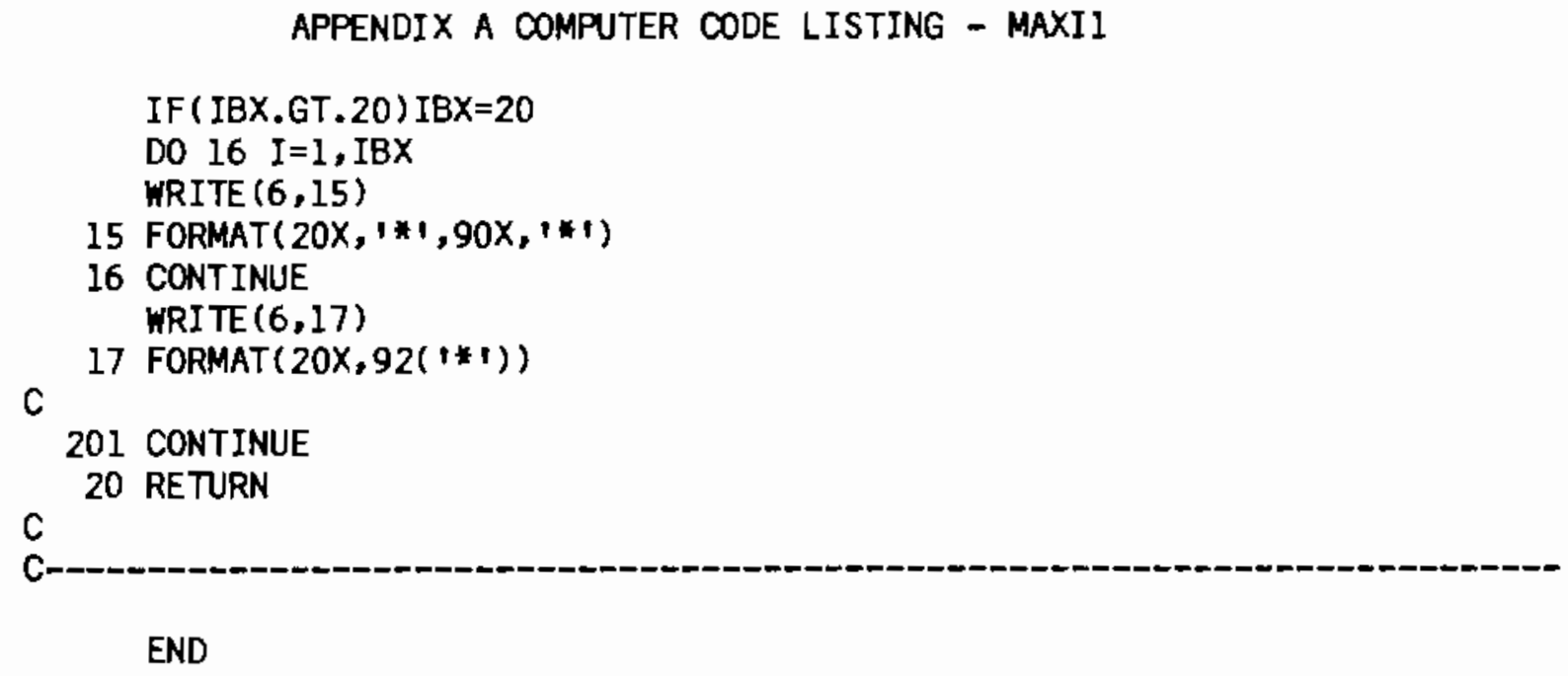


APPENDIX A COMPUTER CODE LISTING - MAXII

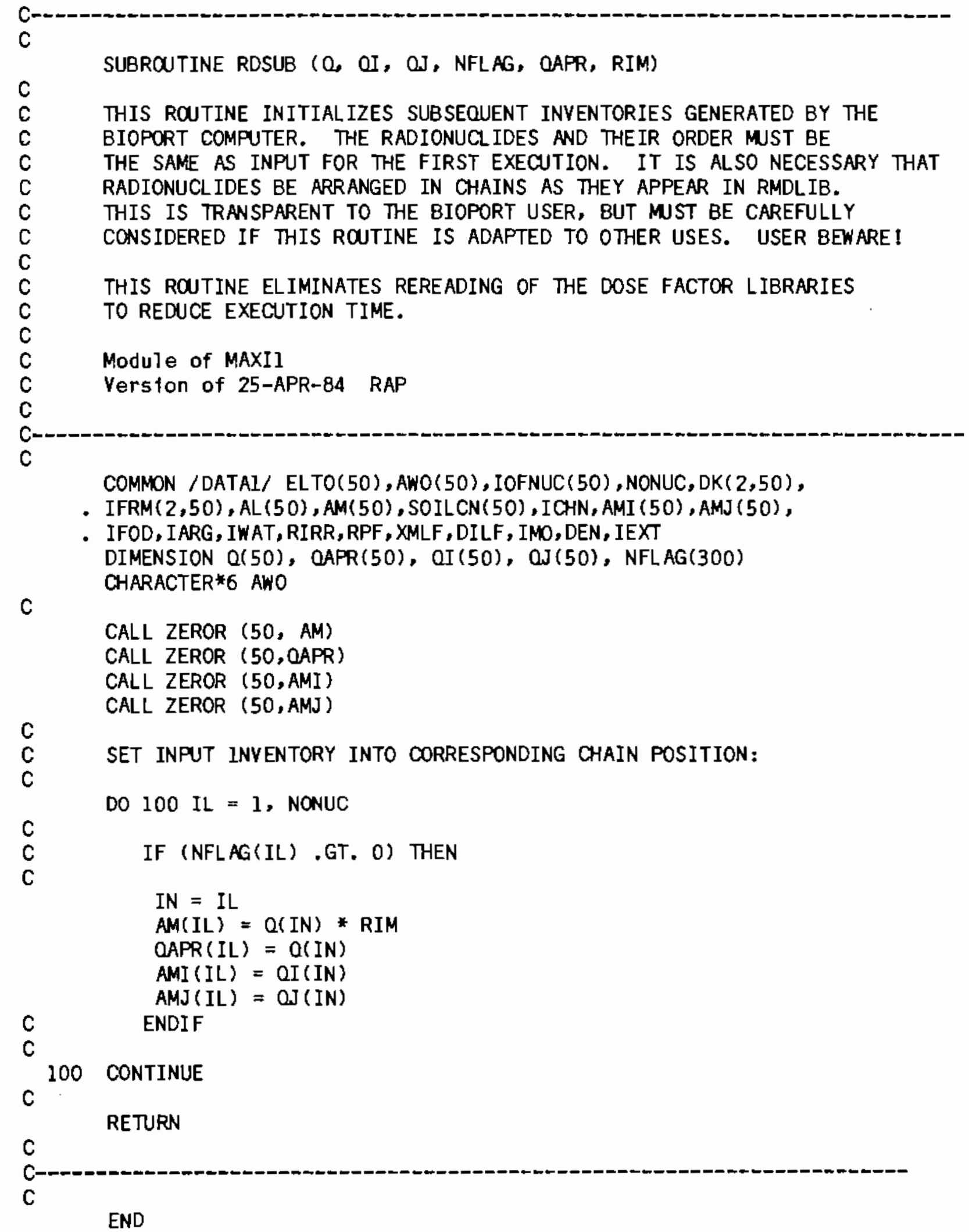


APPENDIX A COMPUTER CODE LISTING - MAXII

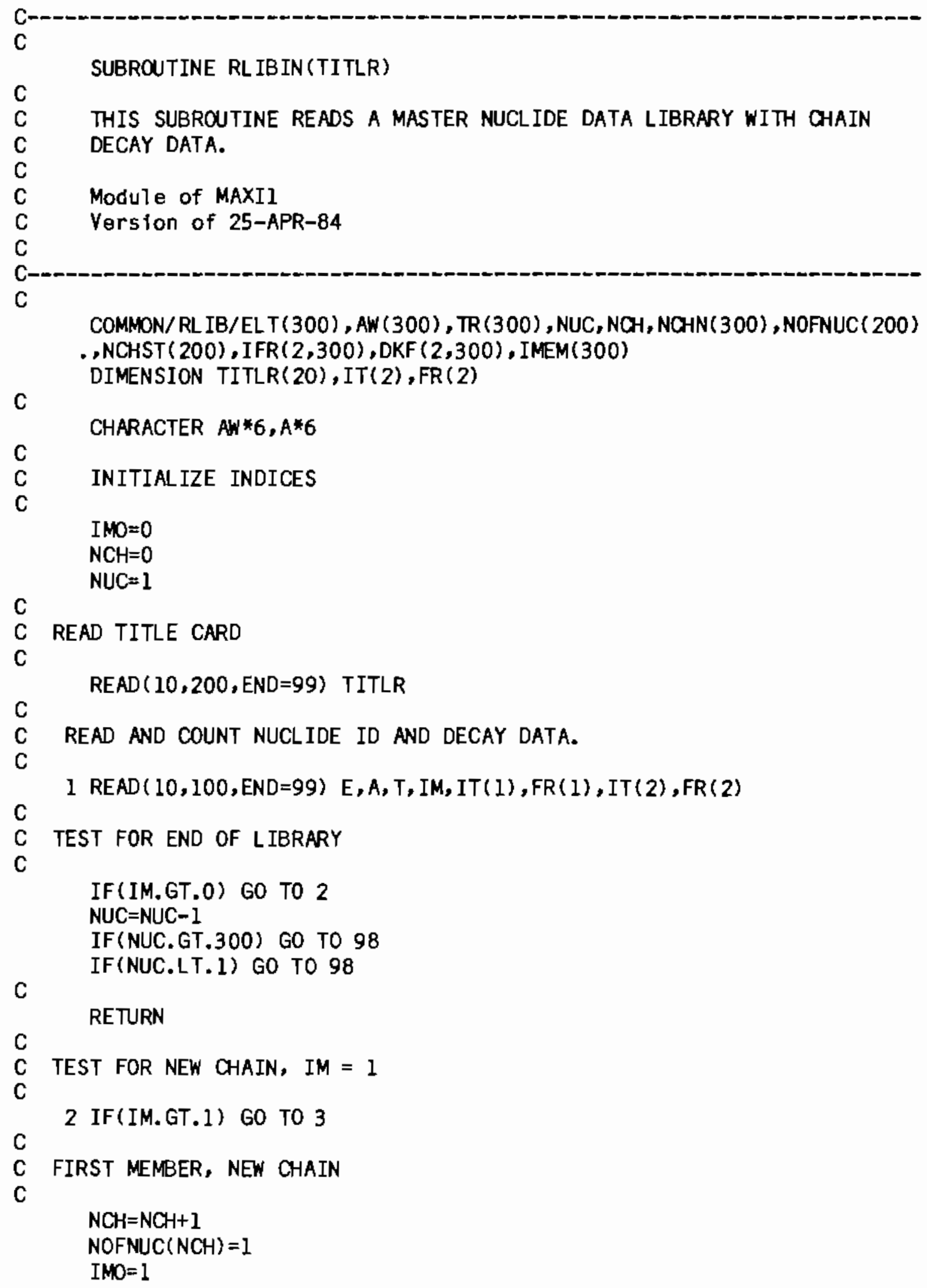




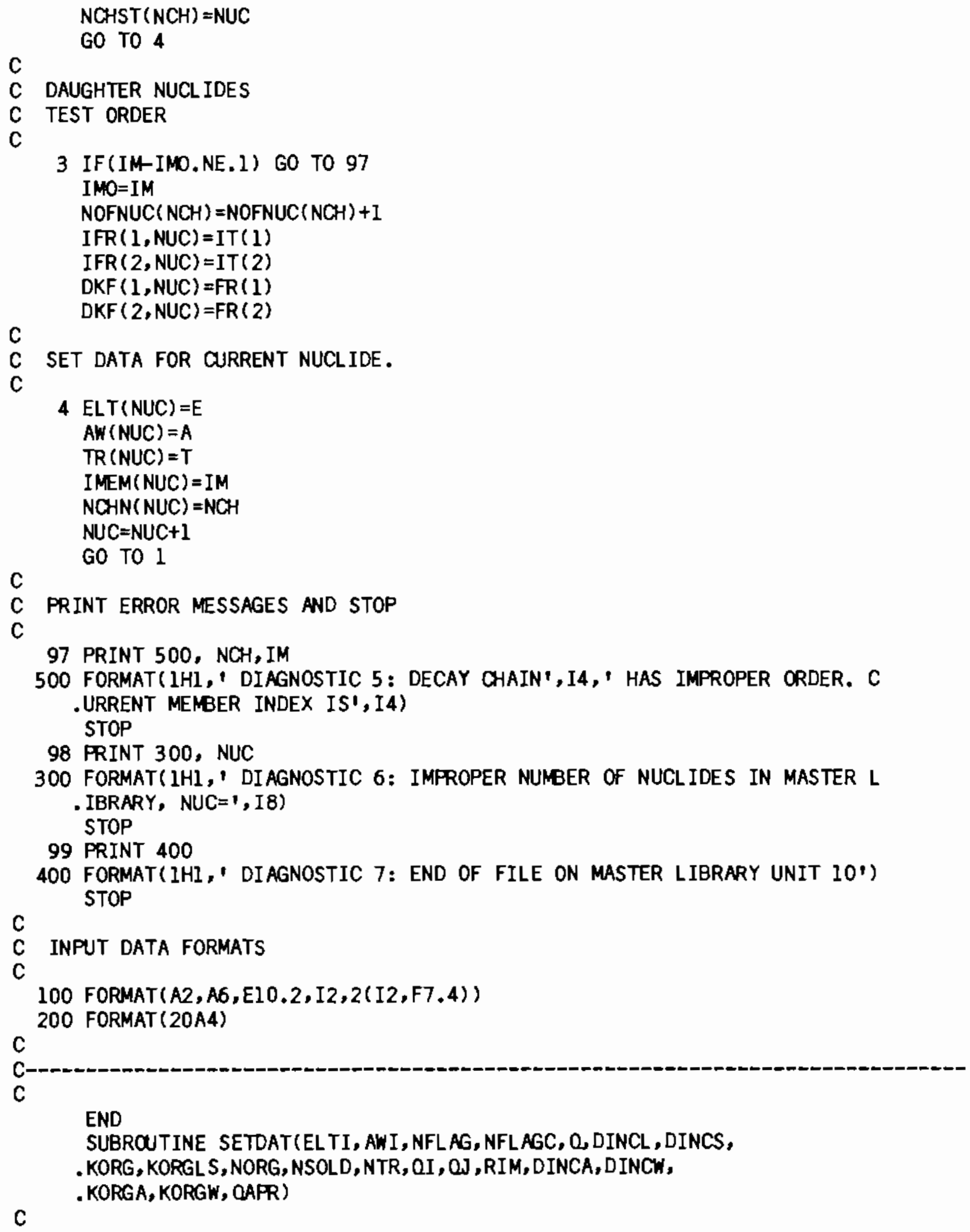


APPENDIX A COMPUTER CODE LISTING - MAXII

C

COMMON/THIRDS/OK(50), AML (50), XOSITE, IAIR, IDKAIR, IBLOW

COMMON/RL IB/ELT(300), AW(300), TR(300), NUC, NCH, NCHN (300), NOFNUC( 200$)$

C , $N$ NCHST $(200), \operatorname{IFR}(2,300), \operatorname{DKF}(2,300), \operatorname{IMEM}(300)$

COMMON/FREAD/ELTLS(100), AWLS(100), ELTX(100), AWX(100), .DFXT (100), . NYRL , NYRS, NORGL , NORGS, NISOL, NISOS, NISOX, .NYRW, NYRA, NORGW, NORGA,NISOW, NISOA, ELTA(100), AW AW(100), . EL TW (100), AWW (100), EL TDX(100), AWDX (100), DFDXT (100), NISODX

C

DIMENSION DINCL $(50,100,5), \operatorname{DINCS}(50,100,5)$, .DINCA $(50,100,5), \operatorname{DINCW}(50,100,5)$

DIMENSION KORG (5), KORGLS(5), NSOLD $(5,50), N T R(5,50)$, . KORGA(5), KORGW(5)

C

COMKON/DATAL/EL TO(50), AWO(50), IOFNUC (50), NONUC, DK $(2,50)$, - $\operatorname{IFRM}(2,50), A L(50), A M(50), \operatorname{SOILCN}(50), \operatorname{ICHN}, \operatorname{AMI}(50), A M J(50)$, . IFOD, IARG, IWAT, RIRR, RPF, XMLF, DILF, IMO,DEN, IEXT

COMMON/DATA2/DFDOS $(50,50,5), \operatorname{AIDOS}(50,50,5), \operatorname{INDOS}(50,50,5)$, .DEXT (50), ARGF $(50,50,5), \operatorname{ARDN}(50,50,5), \operatorname{DEDXT}(50)$

C

C

DIMENSION ELTI(50), AWI (50), NFLAG (300), NFLAGC $(200), 0(50)$

DIMENSION OI $(50)$, OJ $(50)$, OAPR $(50)$

CHARACTER*6 AW, AWLS, AWX, AW I, AWO, AW AW, AWW, AWDX

C

REAL*4 INDOS

INUC $=0$

$I C H N=0$

CALL ZEROR(50,ELTO)

C CALL ZEROR (50,AWO)

DO 8881 IRAP $=1,50$

$A$ NO (IRAP) $=1$,

8881 CONTINUE

CALL ZEROI $(50$, IOFNUC $)$

CALL ZEROR(50, AL)

CALL ZEROR $(50, A M)$

CALL ZEROI $(250$, NTR $)$

C

C LOOP ON ALL CHAINS FROM MASTER LIBRARY

C

DO $20 \mathrm{IC}=1, \mathrm{NCH}$

C

C IF THIS CHAIN IS NOT USED, THEN SKIP TO 20

$\mathrm{C}$

IF (NFLAGC(IC).NE.1)GO TO 20

C

$I C H N=I C H N+I$

$N C N=N O F N U C(I C)$ 


\section{APPENDIX A COMPUTER CODE LISTING - MAXII}

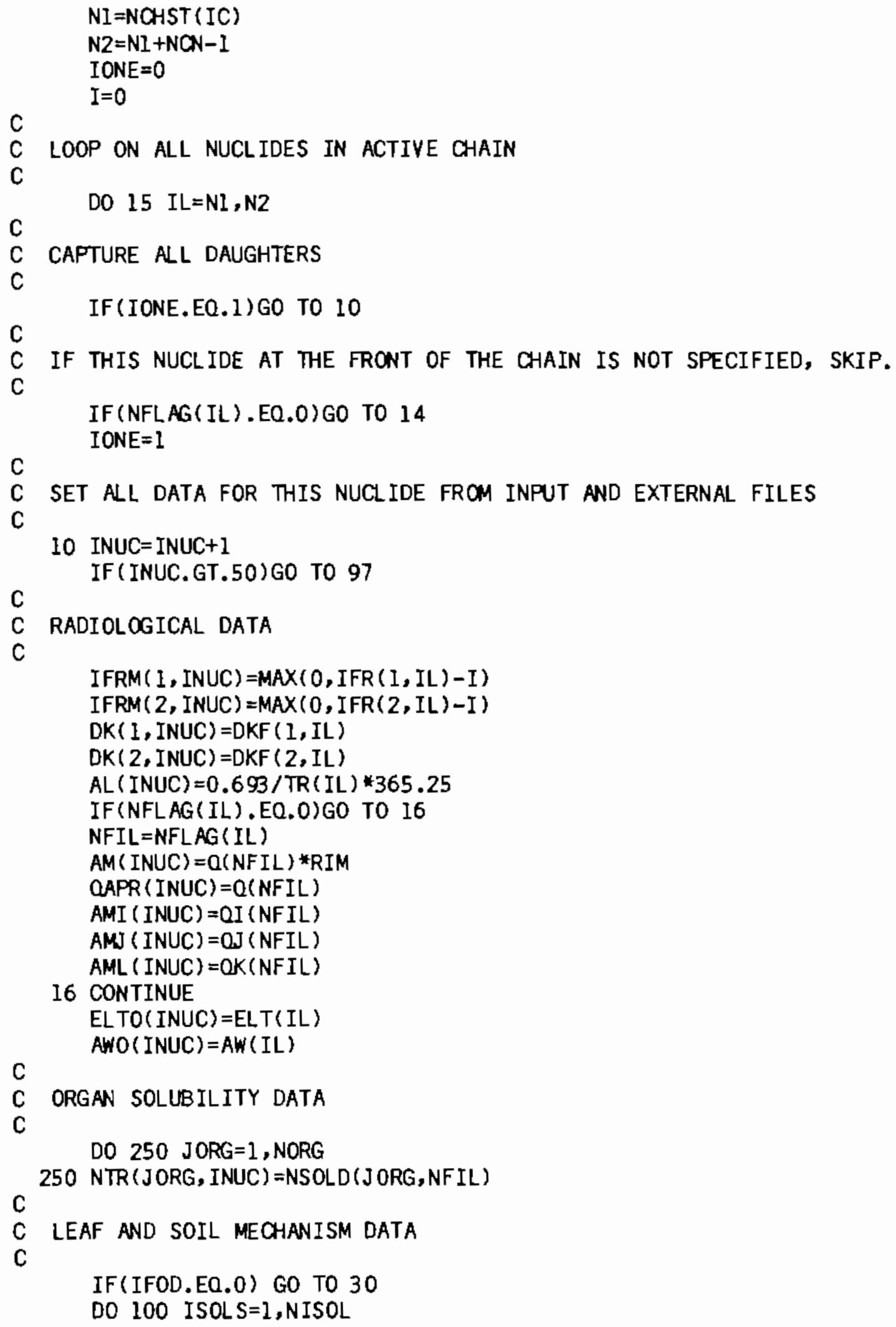






APPENDIX A COMPUTER CODE LISTING - MAXII 





APPENDIX A COMPUTER CODE LISTING - MAXII

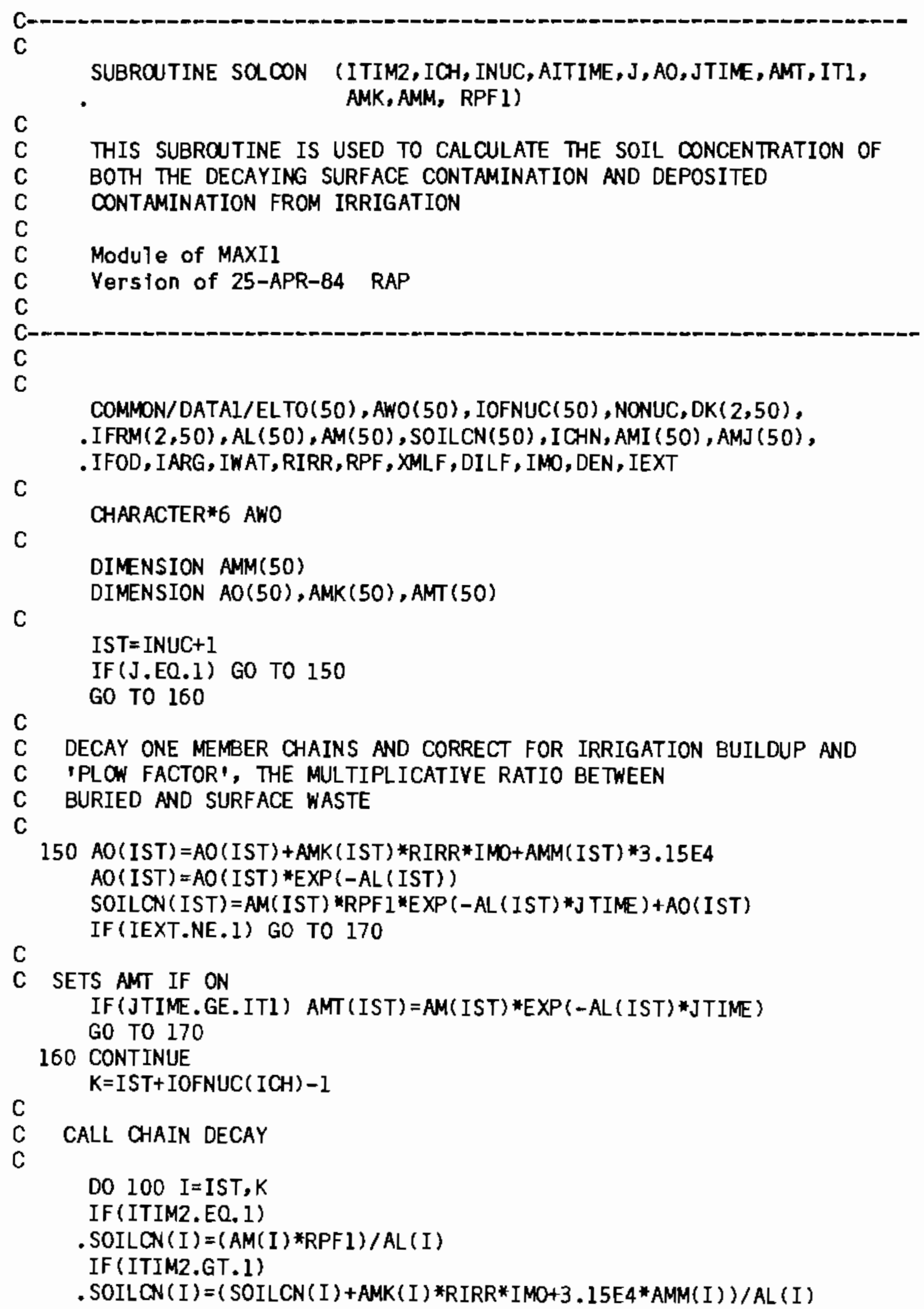


APPENDIX A COMPUTER CODE LISTING - MAXII




APPENDIX A COMPUTER CODE LISTING - MAXII

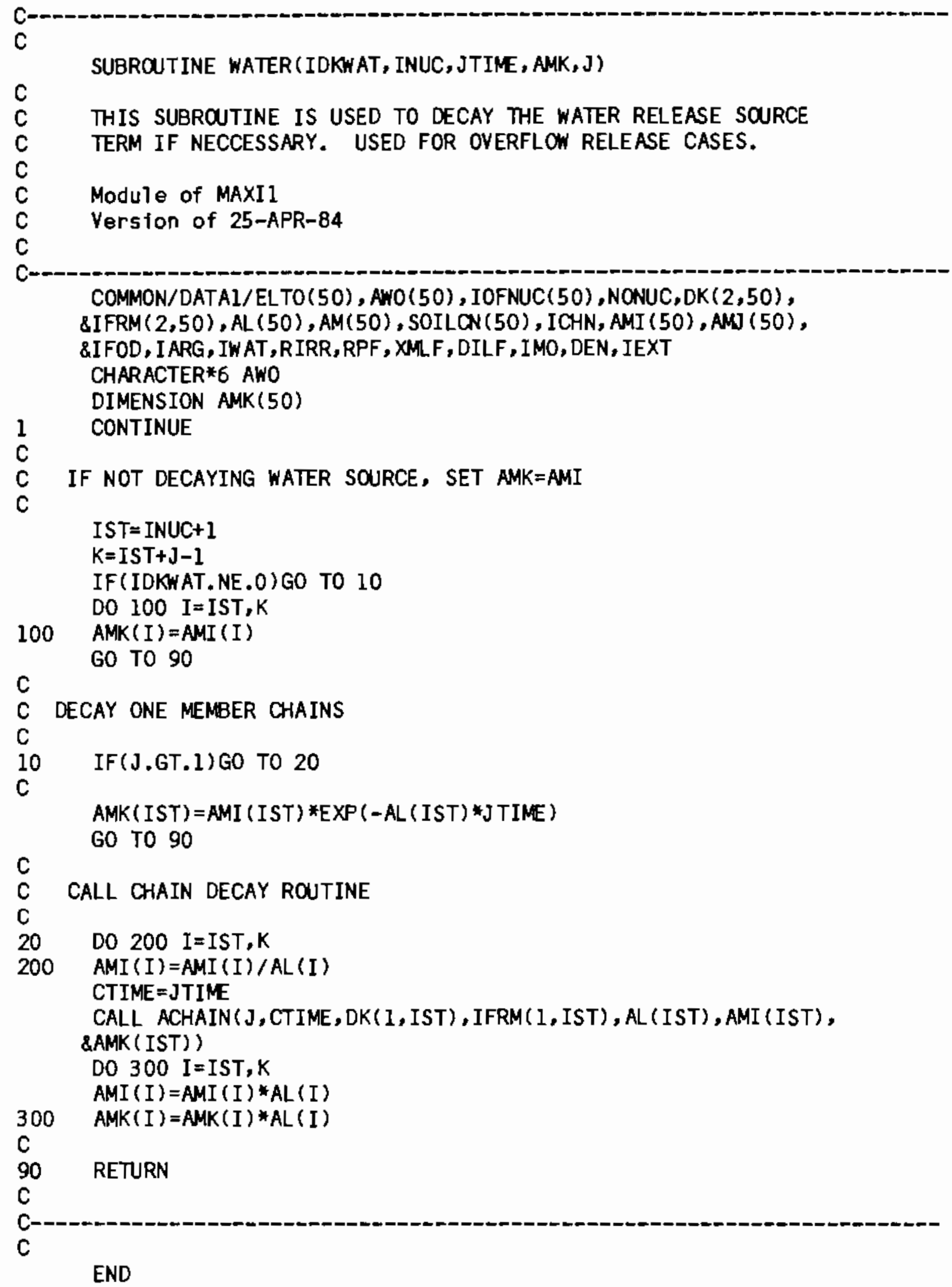


APPENDIX A COMPUTER CODE LISTING - MAXII

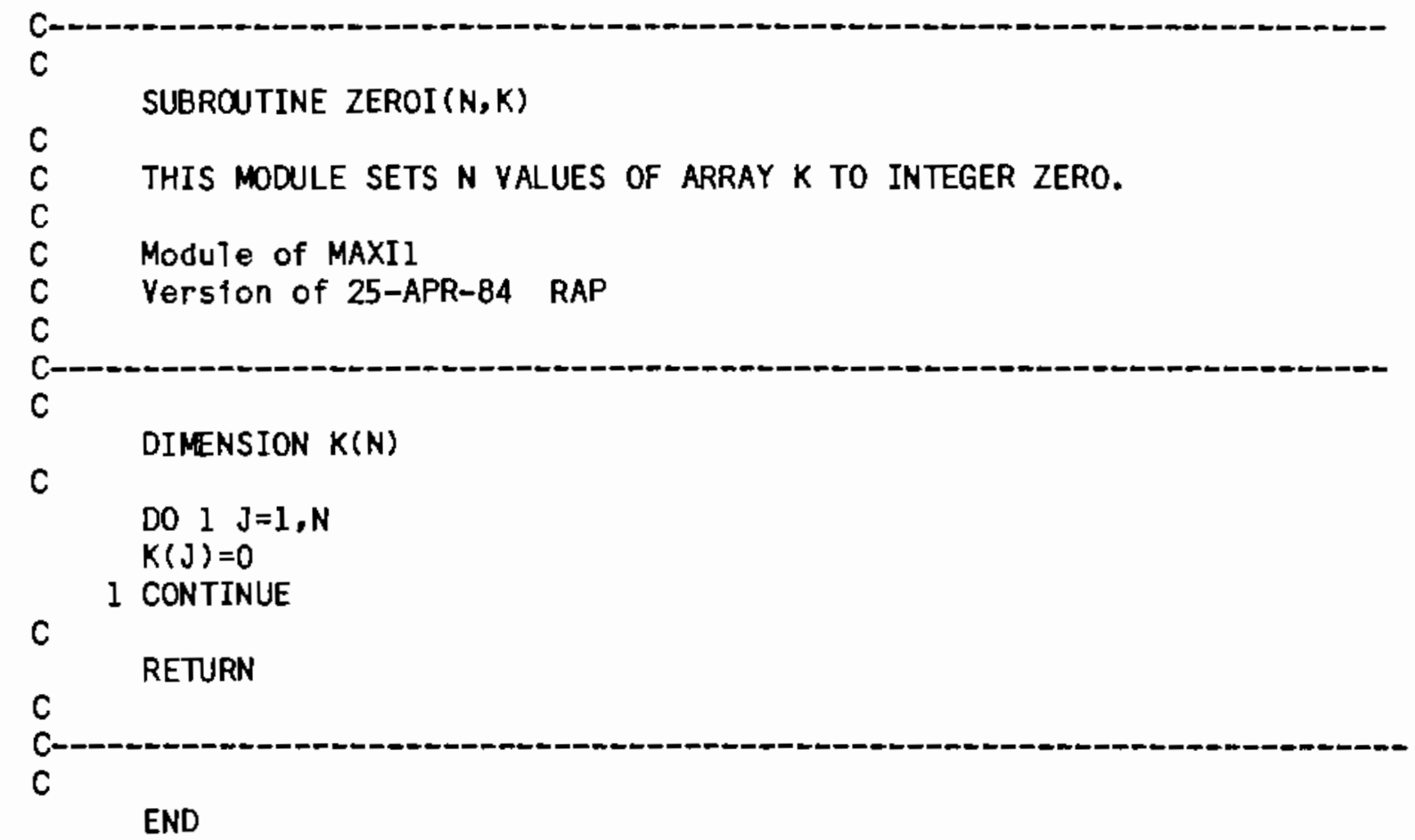


APPENDIX A COMPUTER CODE LISTING - MAXII

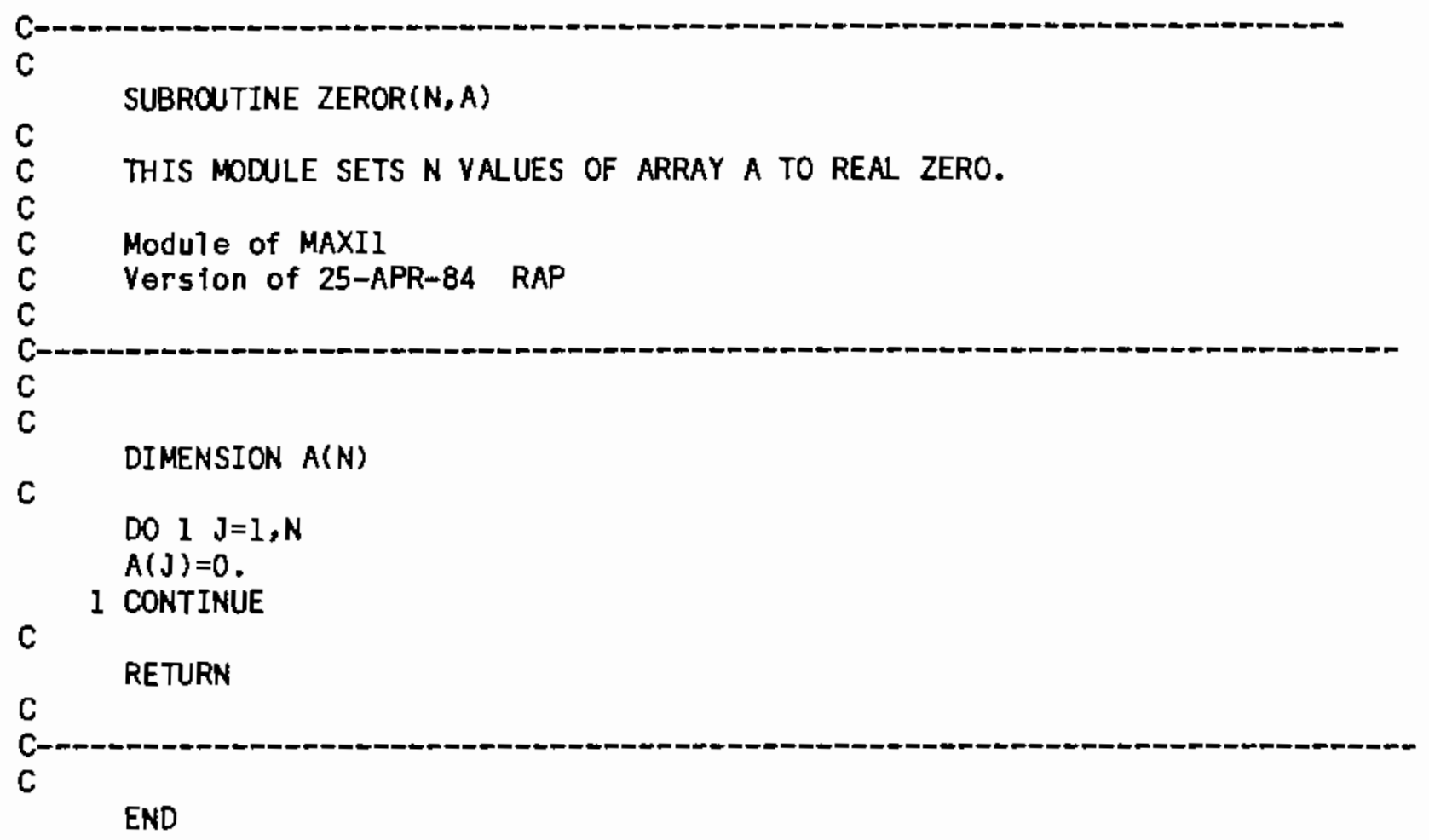



APPENDIX B

COMPUTER CODE LISTING - ONSITE 
APPENDIX B COMPUTER CODE LISTING - ONSITE

\section{Program Title: ONSITE}

Developed for: U.S. Nucear Regulatory Commission

Office of Nuclear Materfal Safety \& Safeguards

Division of Waste Management

Date: $\quad$ March 29, 1985

NRC Contact: Dr. Stan Neuder

Phone: $301-427-4533$

Code Developer: B.A. Napter, R.A. Peloquin, W.E. Kennedy, Jr. Pacific Northwest Laboratory Richland, WA 509-375-3849 (WEK)

Th1s program was prepared for an agency of the United States Government. Neither the United States government nor any agency thereof, or any of thei $r$ employees, make any warranty, expressed or implfed, or assumes any legal liability or responsibitity for any third party's use, or the results of such use, of any portion of this program or represents that 1ts use by such third party would not infringe privately owned rights.

C

C

ONSITE is the interactive user/system interface for the ONSITE Disposal Version of the MAXIl computer code. ONSITE creates a file containing the $\mathrm{JCL}$ and input stream for MAXIl.

Version of 3-APR-85 RAP

The program ONSITE includes the following modules:


to input the new value 


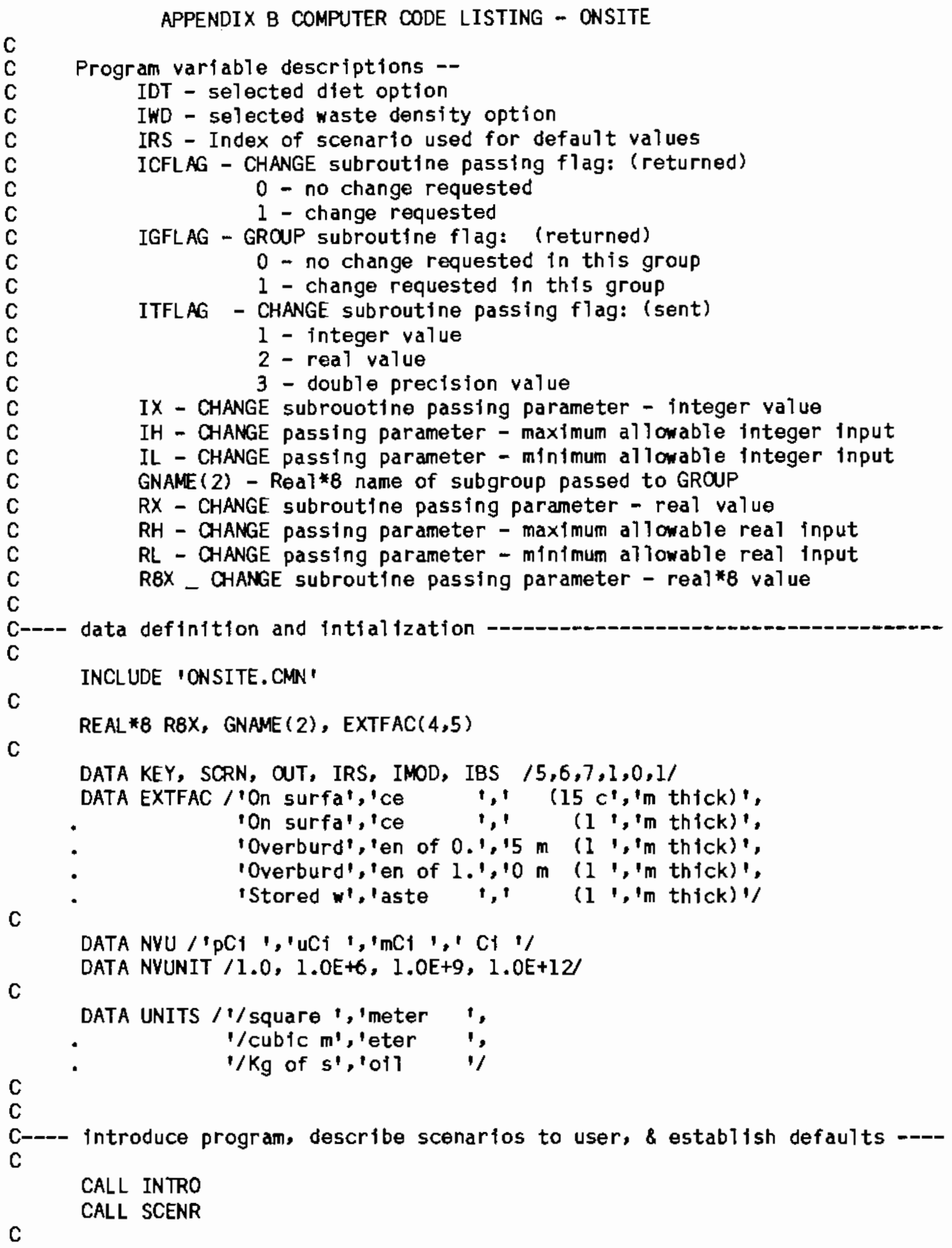


APPENDIX B COMPUTER CODE LISTING - ONSITE

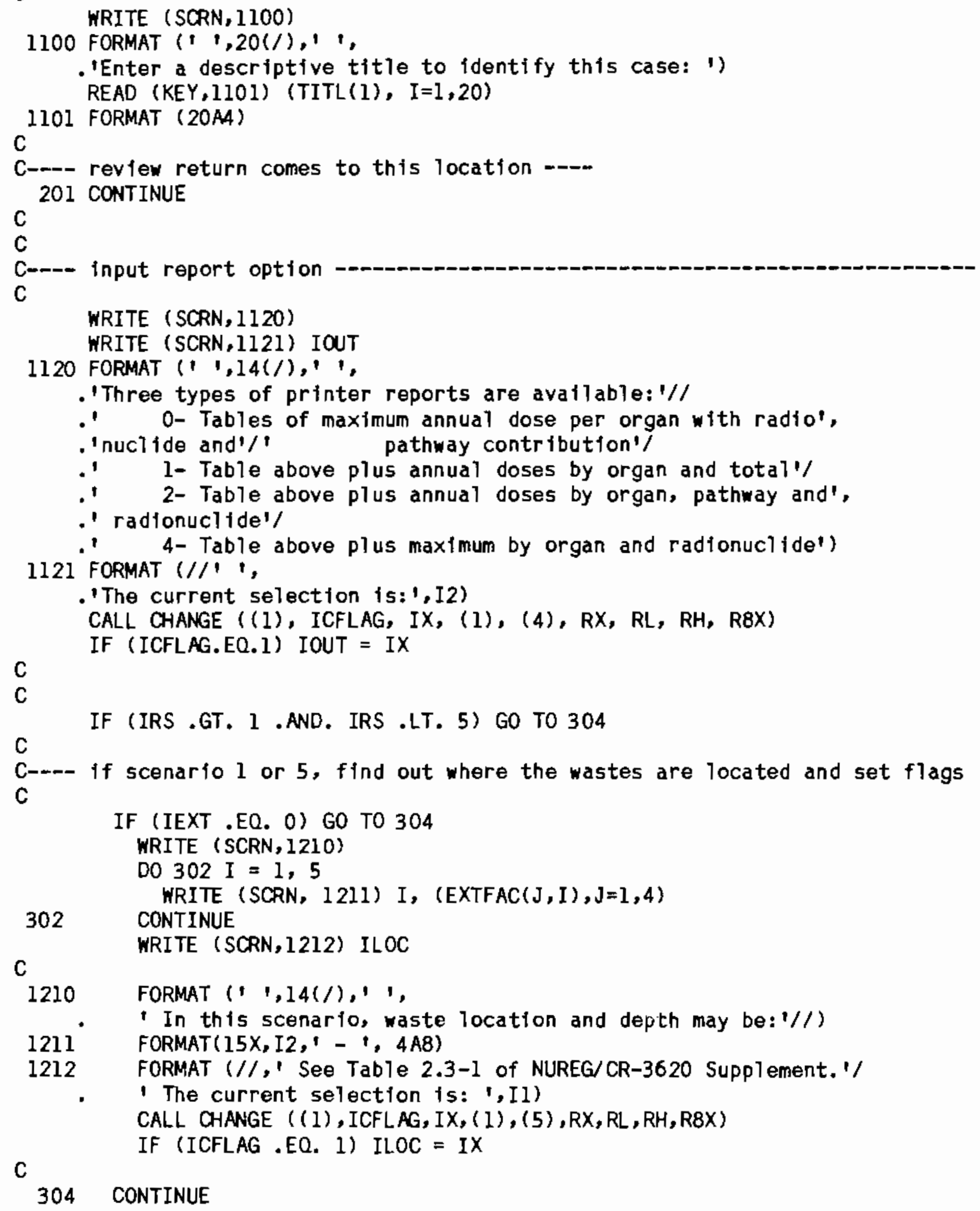




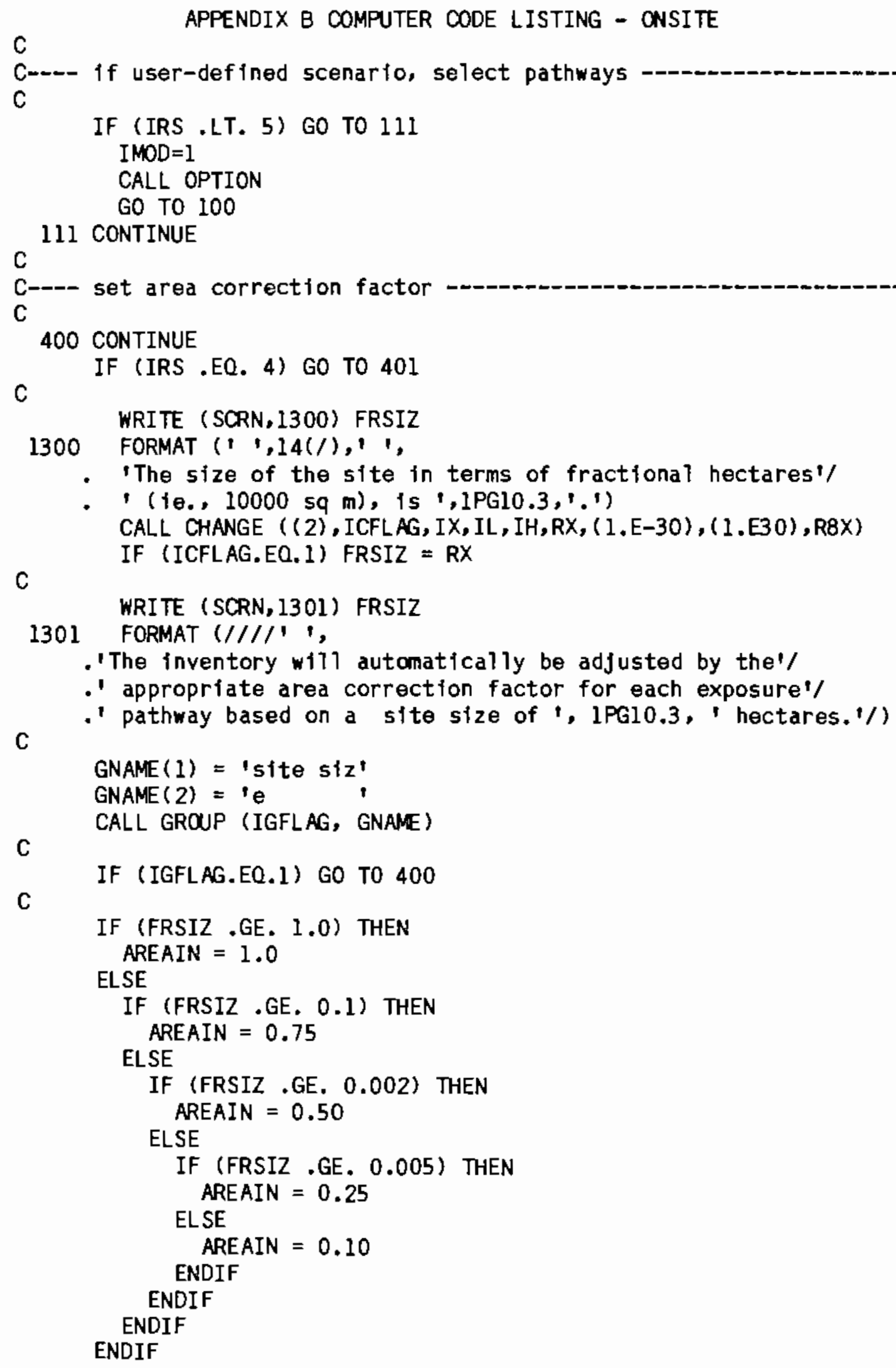


C

APPENDIX B COMPUTER CODE LISTING - ONSITE

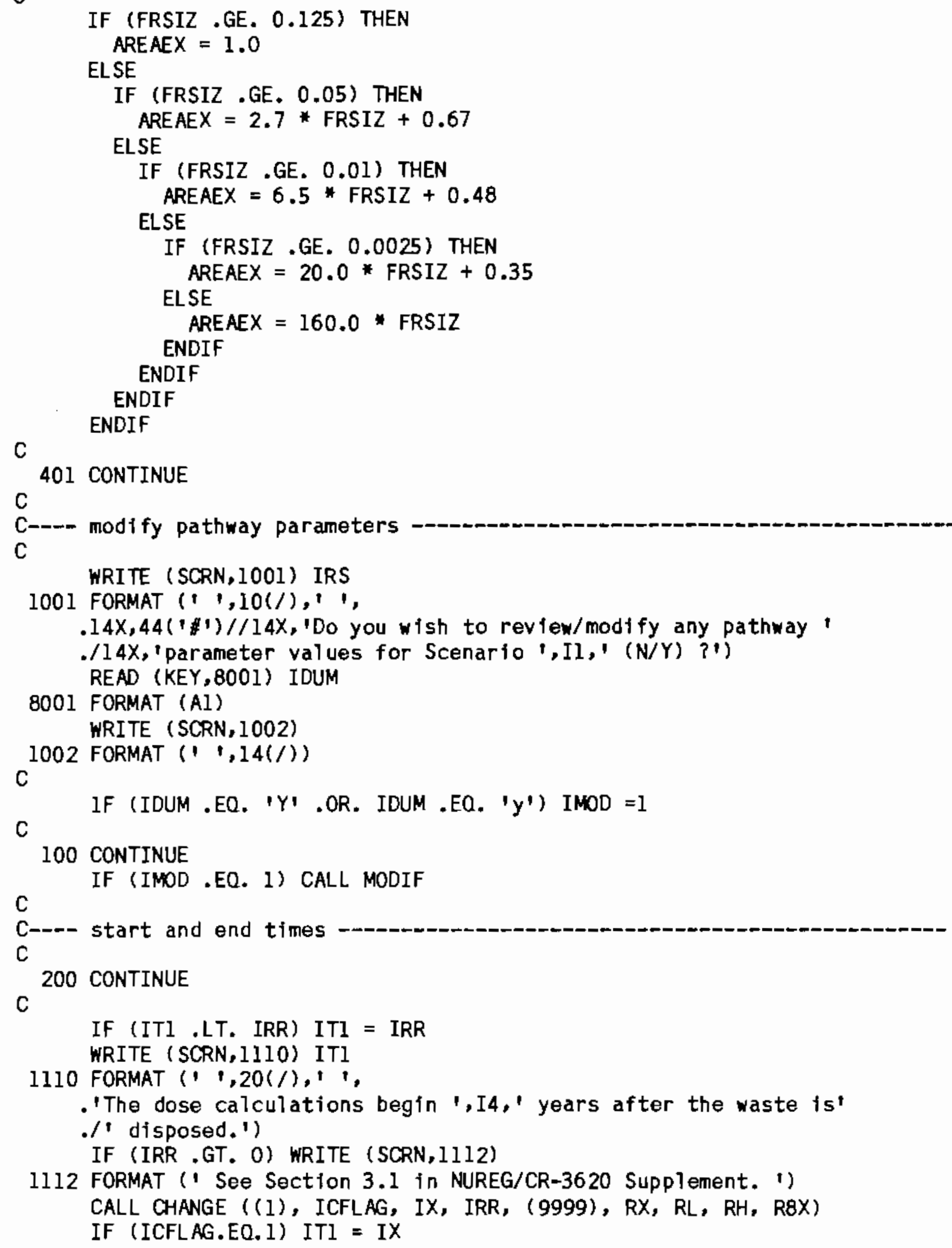


C

APPENDIX B COMPUTER CODE LISTING - ONSITE

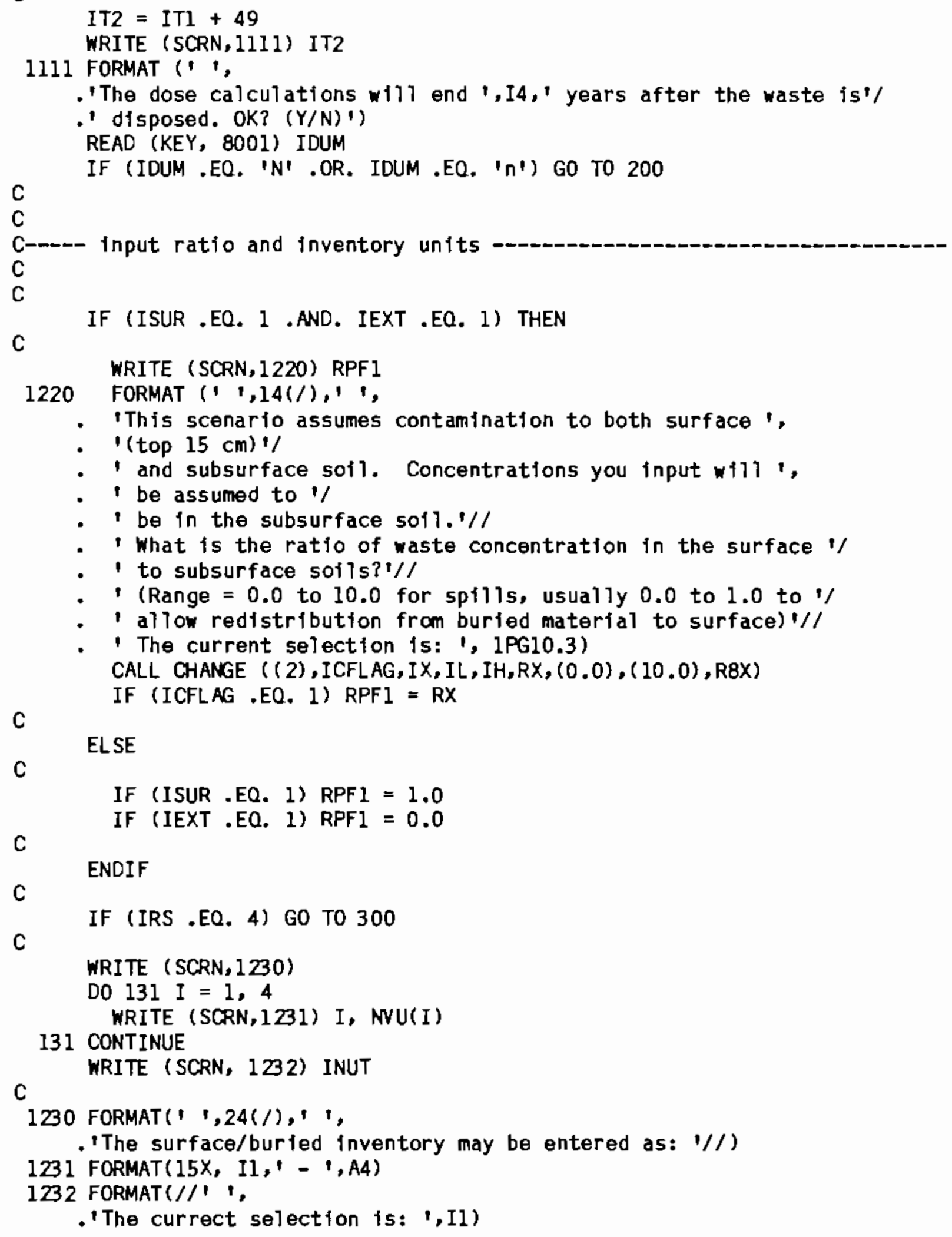


APPENDIX B COMPUTER CODE LISTING - ONSITE

CALL CHANGE ((1), ICFLAG, IX, (1), (4), RX, RL, RH, R8X)

IF (ICFLAG .EQ. I) INUT $=$ IX

C

WRITE (SCRN,1200)

DO $142 I=1,3$

$I M B=I-1$

WRITE (SCRN, 120I) IMB, NVU(INUT), (UNITS $(J, I), J=1,2)$

142 CONTINUE

WRITE (SCRN,1202) M3M2

C

1200 FORMAT (' 1,14(/), 1,

- The contamination deposited on the site at start of'/

- ' calculation may be entered in the following units:1//)

1201 FORMAT (15X, Il, - ',A4,2A8)

1202 FORMAT $(/ /$, ' Usually 0 for surface contamination and ',

- '1 for buried'/

- ' contamination. The current selection is: 1,Il)

CALL CHANGE ( (1), ICFLAG, IX, (0), (2), RX, RL, RH, R8X)

C IF (ICFLAG .EQ. 1) $M 3 M 2=I X$

C

300 CONTINUE

IF (IRS .EQ. 4) GO TO 301

C

WRITE (SCRN, 1250) SRDIL

FORMAT( $1,14(/), 1$ ',

- The radionuclide inventory modification factor is: ',IPG10.2/

- ' (range $=0.0$ to $1.0 \mathrm{E}+20$, usua 11 y 0.0 to 1.0 ) $1 / 1$

- 'This factor will be used as a multiplier of all input"/

- ' concentrations. It is a handy parameter to correct units'/

- 'or make other changes (such as dilution of inventory with'/

- 'clean solt).1)

CALL CHANGE ((2), ICFLAG, IX, IL, IH, RX, (0.0), (1.E20), R8X)

301 CONTINUE

IF (ICFLAG .EQ. 1) SRDIL = RX

C

$\mathrm{C}$

C---- allow user to review parameters before entering the inventory

C

$\operatorname{GNAME}(1)=$ 'any of $t$ '

GNAME (2) = 'he above'

CALL GROUP (IGFLAG, GNAME)

IF (IGFLAG .EO. 1) THEN

$I M O D=0$

GO TO 201

ENDIF

C

C

C---- input inventory and write file

C 
APPENDIX B COMPUTER CODE LISTING - ONSITE




APPENDIX B COMPUTER CODE LISTING - ONSITE






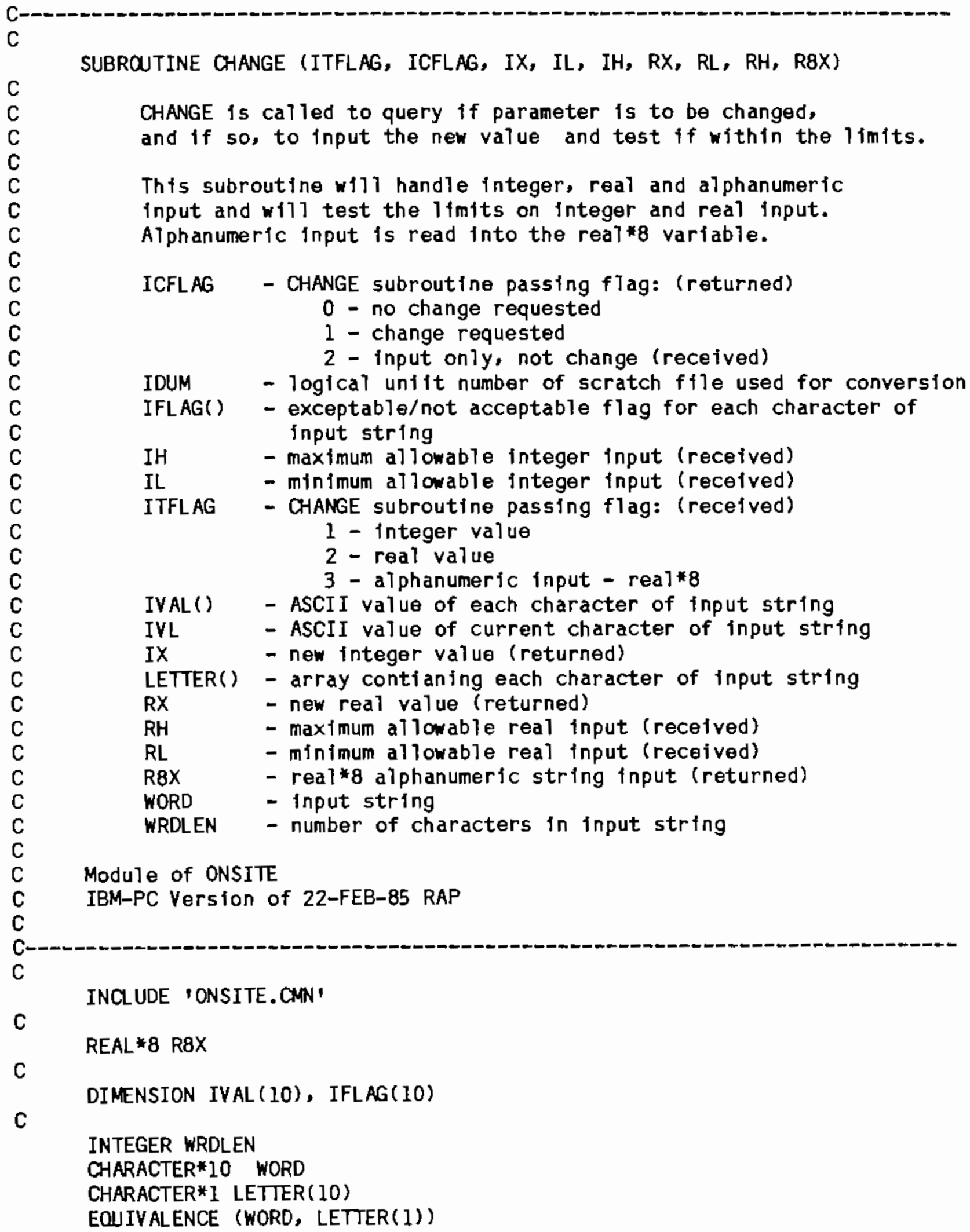


C

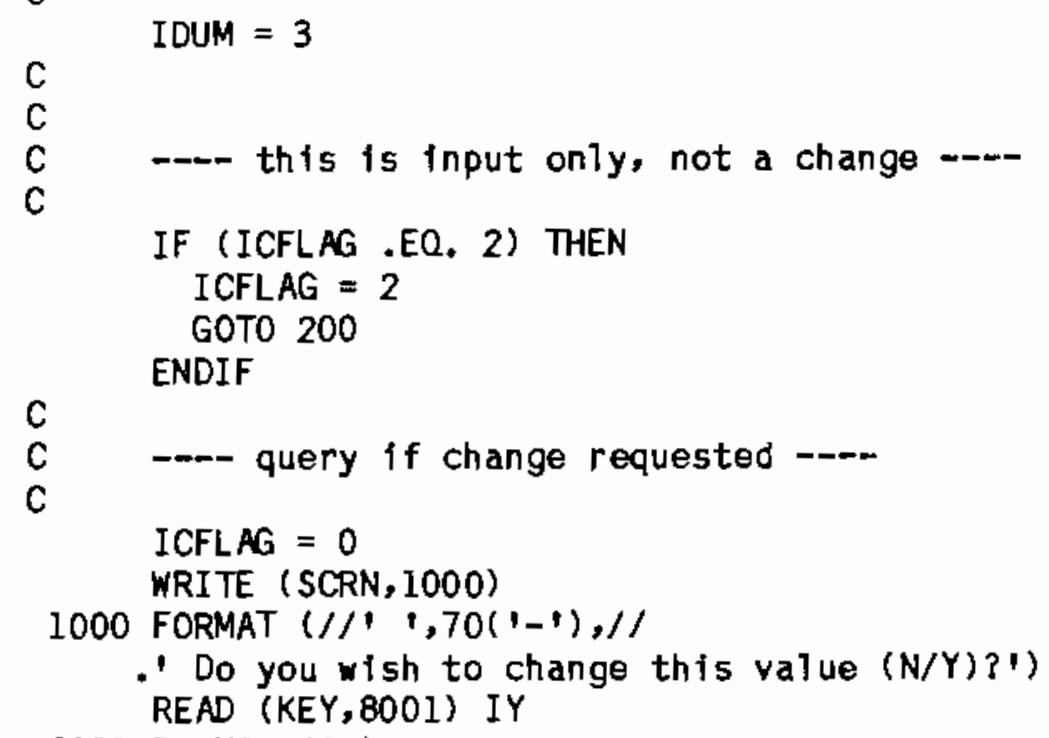

C

WRDLEN $=$ WRDLEN $+I$

$\operatorname{IFLAG}(I)=0$

IVL = ICHAR (LETTER(I))

$\operatorname{IVAL}(I)=I V L$

$\stackrel{C}{C}$

--- all numerals are valid --.--

IF (IVL .LT. 48) IFLAG(I) $=1$

IF (IVL .GT. 57) IFLAG(I) $=1$

C

C

IF (IFLAG(I), GT, O) THEN 


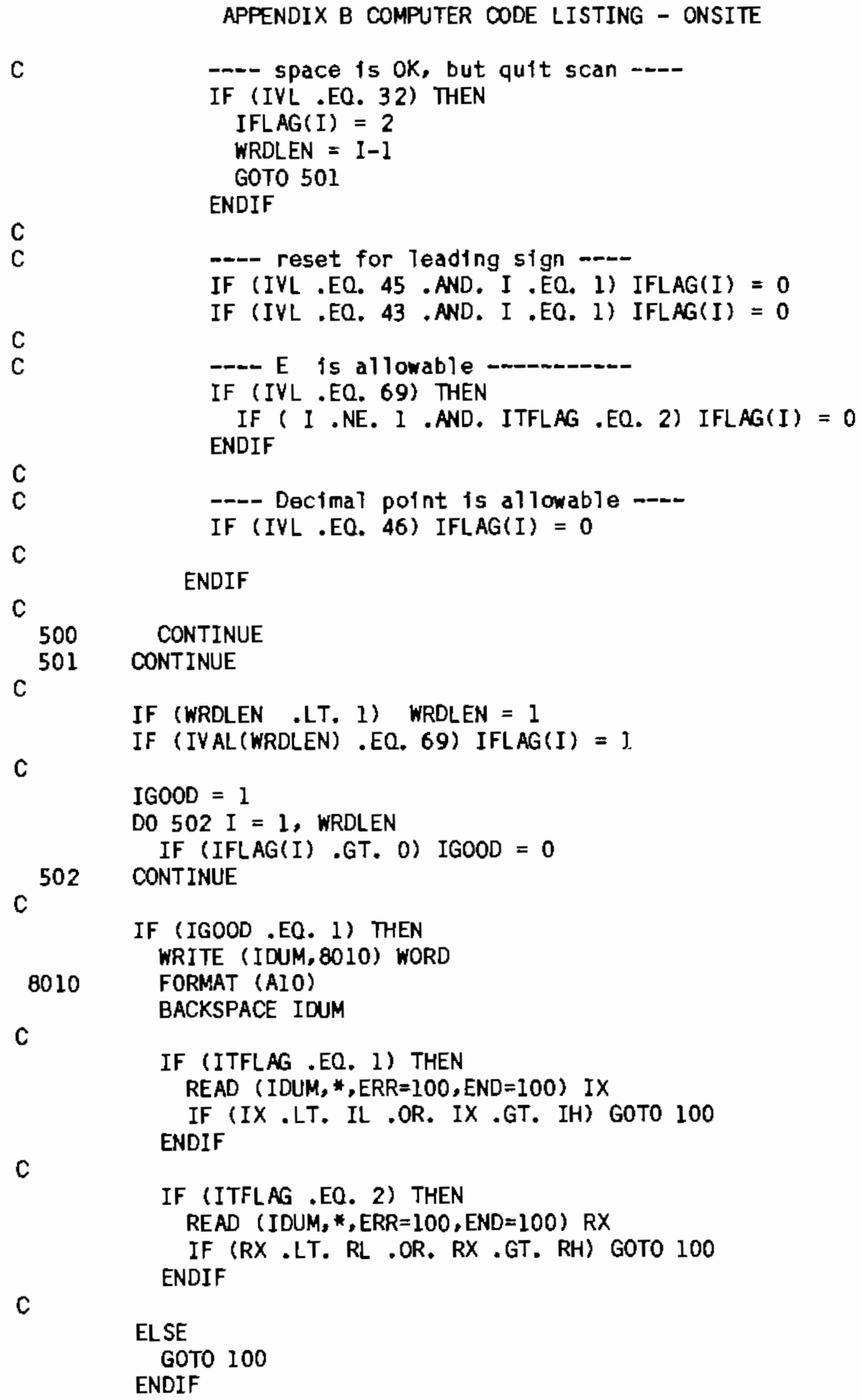

C 


\section{APPENDIX B COMPUTER CODE LISTING - ONSITE}

C

700 CONTINUE

c

WRITE (SCRN,1001)

1001 FORMAT $(1,10(/))$

C

RETURN

C ... format statements -..-

C

8003 FORMAT (A8)

$\mathrm{C}$

C-10-

$\mathrm{C}$

END

B. 13 


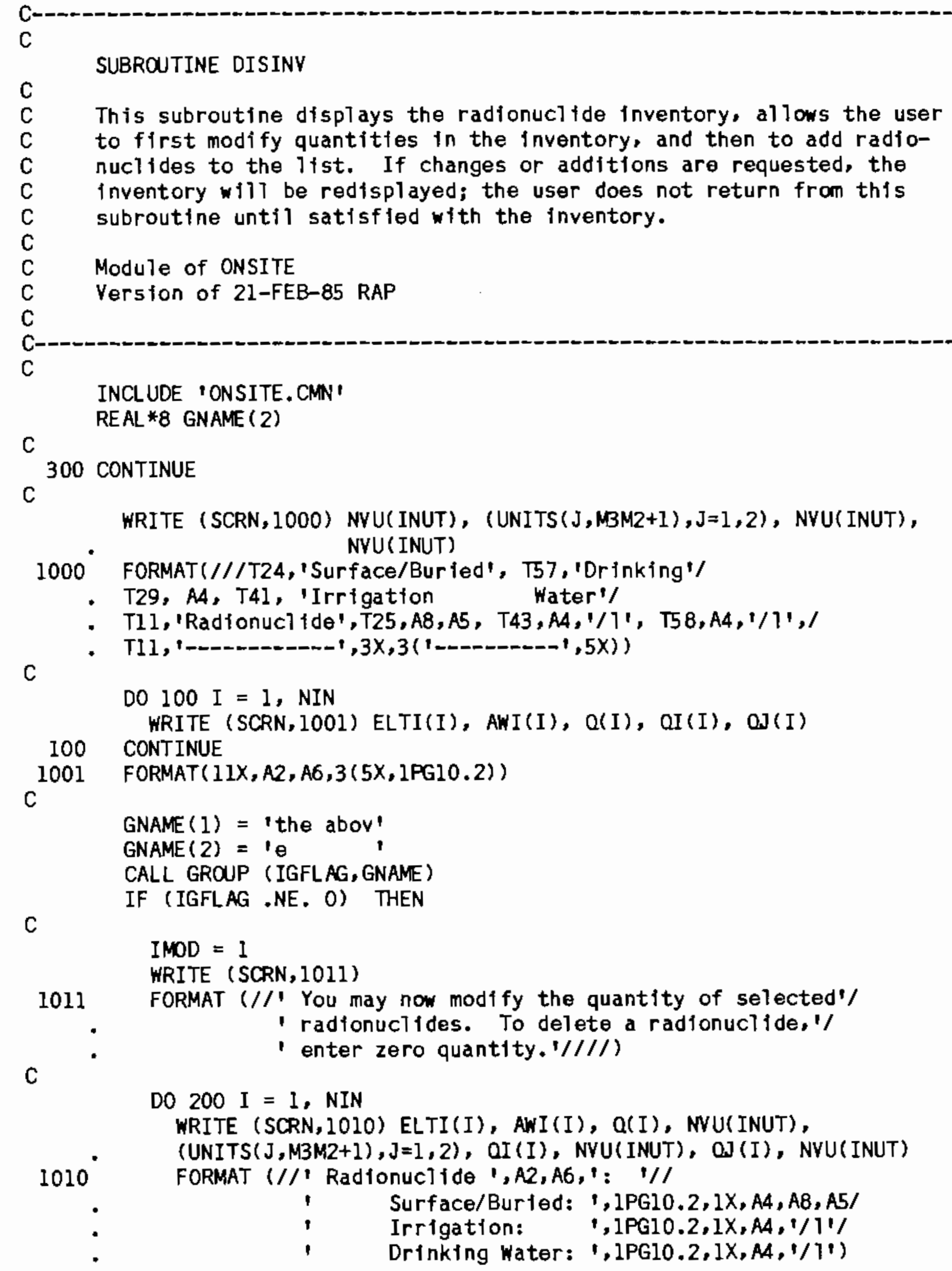$$
\text { C }
$$

\section{SUBROUTINE DISINV}

c

C

$\mathrm{C}$

$\mathrm{C}$

$\mathrm{C}$

$\mathrm{C}$

$\mathrm{C}$

$\mathrm{C}$

C

$\mathrm{C}$

C

C

C

This subroutine displays the radionuclide inventory, allows the user to first modify quantities in the inventory, and then to add radionuclides to the list. If changes or additions are requested, the inventory will be redisplayed; the user does not return from this subroutine until satisfled with the inventory.

ModuTe of ONSITE

Verstion of 21-FEB-85 RAP

INCLUDE 'ONSITE. CMN'

REAL*8 GNAME (2)

300 CONTINUE

WRITE (SCRN, 1000) NVU(INUT), (UNITS ( $J, M B M 2+1), J=1,2)$, NVU(INUT), NVU (INUT)

$1000^{\circ}$ FORMAT(///T24,'Surface/Burled', T57, 'Drinking'/

- T29, A4, T41, 'Irrigation Hater'/

- T1l,'Radionuclide',T25,A8,A5, T43,A4,1/1', T58,A4,1/1',1

- TIl,

C

DO $100 I=1, N I N$

WRITE (SCRN, 1001) ELTI(I), AWI(I), Q(I), OI(I), OJ(I)

100 CONTINUE

1001 FORMAT (11X,A2, A6,3(5X,1PG10.2))

C

GNAME $(1)=$ the abov'
GNAME $(2)=1 \theta$ '
CALL GROUP (IGFLAG, GNAME)
IF (IGFLAG.NE. O) THEN

C

$I M O D=I$

HRITE (SCRN,1011)

1011 FORMAT (//' You may now modffy the quantity of selected'/

- radionucifides. To delete a radionuclide, 1/

' enter zero quantity. '1///1

$\mathrm{C}$

DO $200 I=I, N I N$

WRITE (SCRN,1010) ELTI(I), AWI(I), Q(I), NVU(INUT),

- (UNITS (J,M3M2+1), J=1,2), OI(I), NVU(INUT), OJ (I), NVU(INUT)

1010 FORMAT (//' Radionuclide ', A2, A6, ': $1 / 1$

- I Surface/Burted: ', IPG10.2, IX, A4, AB, A5/

$\cdot$

Irrigation:

$1,1 P G 10.2,1 X, A 4,1 / 11$

Drinking water: ',IPG10.2,IX,A4, I/11) 


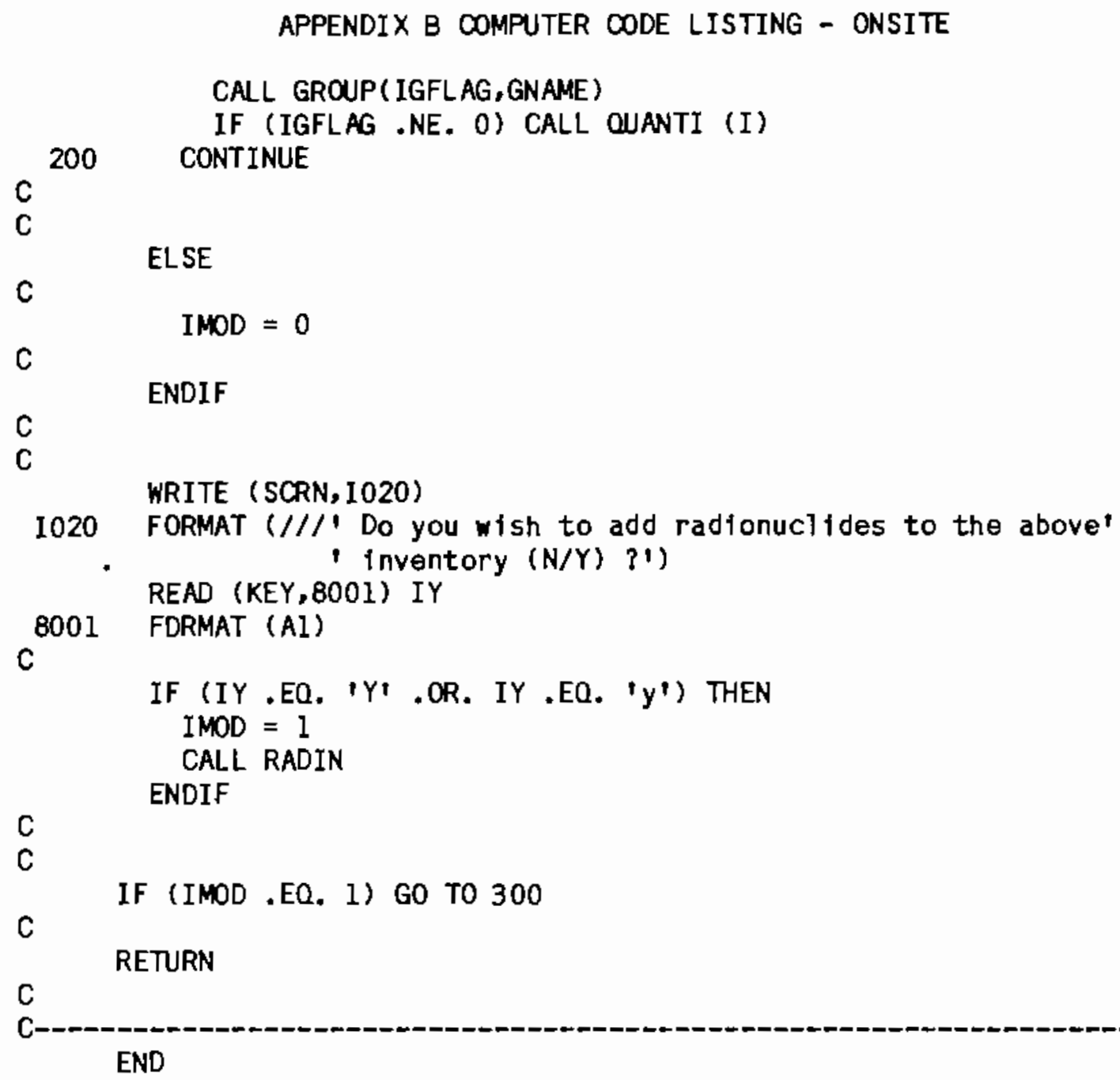




\section{APPENDIX B COMPUTER CODE LISTING - ONSITE}




APPENDIX B COMPUTER CODE LISTING - ONSITE

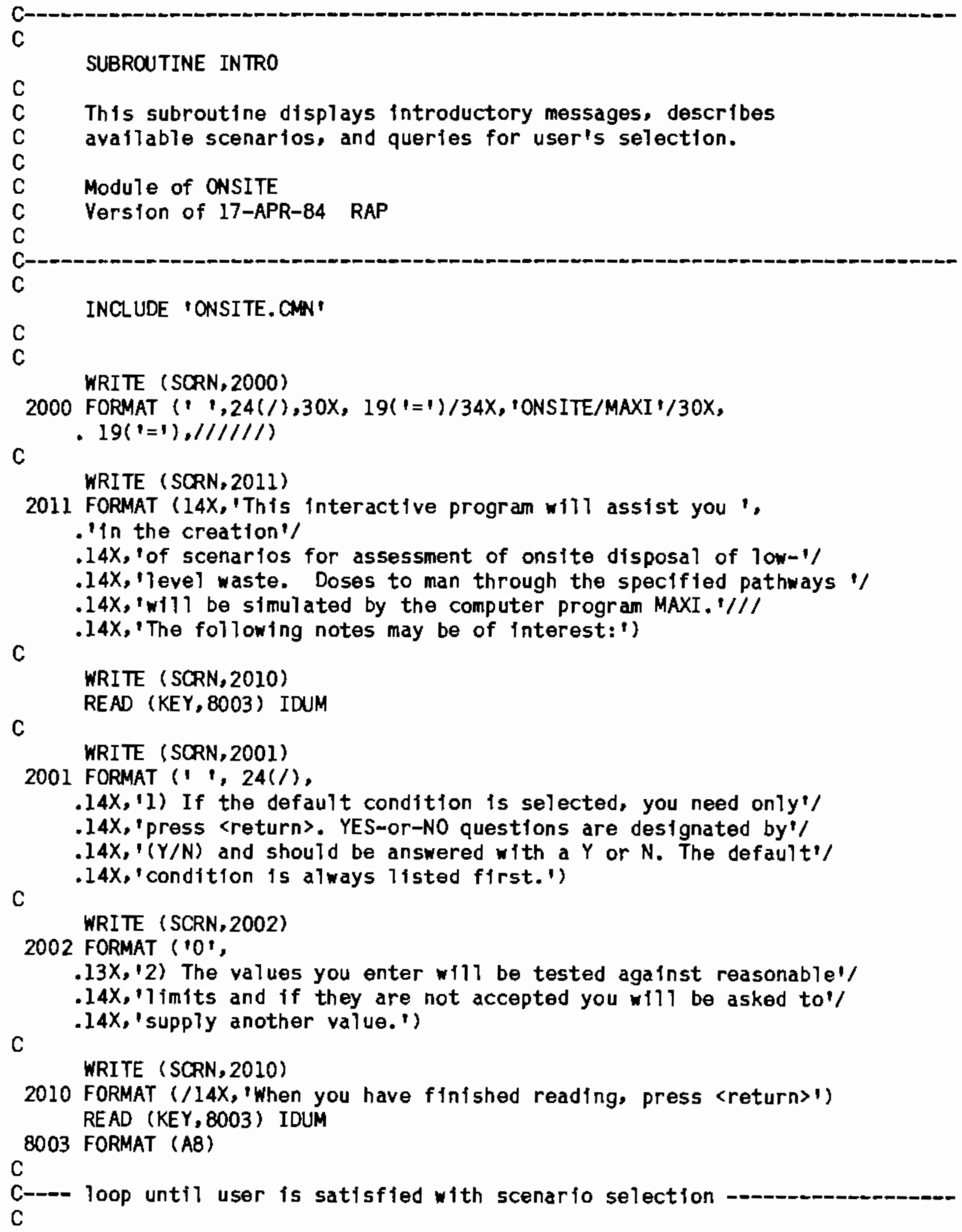


APPENDIX B COMPUTER CODE LISTING - ONSITE

$\mathrm{C}$

100 CONTINUE

CALL SELECT

C

IF (IRS .EO. 1) WRITE (SCRN,2100)

2100 FORMAT (' $1,24(1)$,

$.14 X$, 'SCENARIO 1: Externa] Exposure'//

.14X, 'This scenario can be used alone or as part of Scenarlos 2'/

$.14 x$, and 3. Occupational conditions of $2000 \mathrm{~h} / \mathrm{yr}$ of external'/

$.14 X, 1$ exposure are assumed. Waste may be located on the surface, 1/

$\mathrm{C}$

$.14 \mathrm{X}$, 'buried at $0.5 \mathrm{~m}$, buried at $1.0 \mathrm{~m}$, or stored.')

IF (IRS .EQ. 2) WRITE (SCRN, 2200)

2200 FORMAT $(1,24(/)$,

.14X, 'SCENARIO 2: Externat Exposure plus Inhalation from Resus', 'penston'//

$.14 X$, 'This scenario assumes surface contamination results over a'/

$.14 \mathrm{X}, 111 \mathrm{mited}$ area. The scenario defaults to $2000 \mathrm{~h} / \mathrm{yr}$ exposure"/

$.14 X$, to surface contamination and inhalation. The Anspaugh')

IF (IRS .EQ. 2) WRITE (SCRN, 2201)

2201 FORMAT (14X,

- 'resuspension model is used. User may define the fraction'/

$.14 \times$, 'of soll in the top $15 \mathrm{~cm}$ containing buried waste (defaults'/

C

$.14 x$, to 0.2$) .1$ )

IF (IRS .EQ, 3) WRITE (SCRN, 2300)

2300 FORMAT (1, $1,24(/)$,

.14X, 'SCENARIO 3: Agricu]tural Activities'//

.14X, 'This scenario assumes surface contamination (as in Scenario'/

$.14 X, ' 2$ ) with farming; defaults to $2000 \mathrm{~h} / \mathrm{yr}$ exposure to surface')

IF (IRS .EQ. 3) WRITE (SCRN, Z301)

2301 FORMAT (14X,

- 'contamination and inhalation. Anspaugh resuspension model'/

$.14 X, 115$ used. Scenario defaults to total diet of fruits, veg-1/

$.14 X$, 'etables, and anjmal products grown on the site. The user'/

$.14 X$, 'may specify the percentage of soll containing waste in the'/

$\mathrm{C}$

$.14 x$, top $15 \mathrm{~cm} .{ }^{*}$ )

IF (IRS .EQ, 4) WRITE (SCRN, 2400)

2400 FORMAT (' $1,24(/)$,

$.14 \mathrm{X}$, 'SCENARIO 4: Irrigation and Drinking Water $1 / /$

$.14 X$, This scenario accounts for the use of well or river water"/

$.14 X, '$ for irrigation and drinking. Assumes an irrigation rate')

IF (IRS .EQ. 4) WRITE (SCRN, 2401)

2401 FORMAT (14X,

- 'of $150 \mathrm{l} / \mathrm{sq} \mathrm{m} / \mathrm{mo}$ for 6 months. Defaults to Anspaugh model'/

$.14 \mathrm{X}$, 'for inhalation. Assumes total diet and 1.21 iters/day of "/

C

$.14 \mathrm{X}$, 'drinking water.')

IF (IRS .EQ, 5) WRITE (SCRN, 2500) 







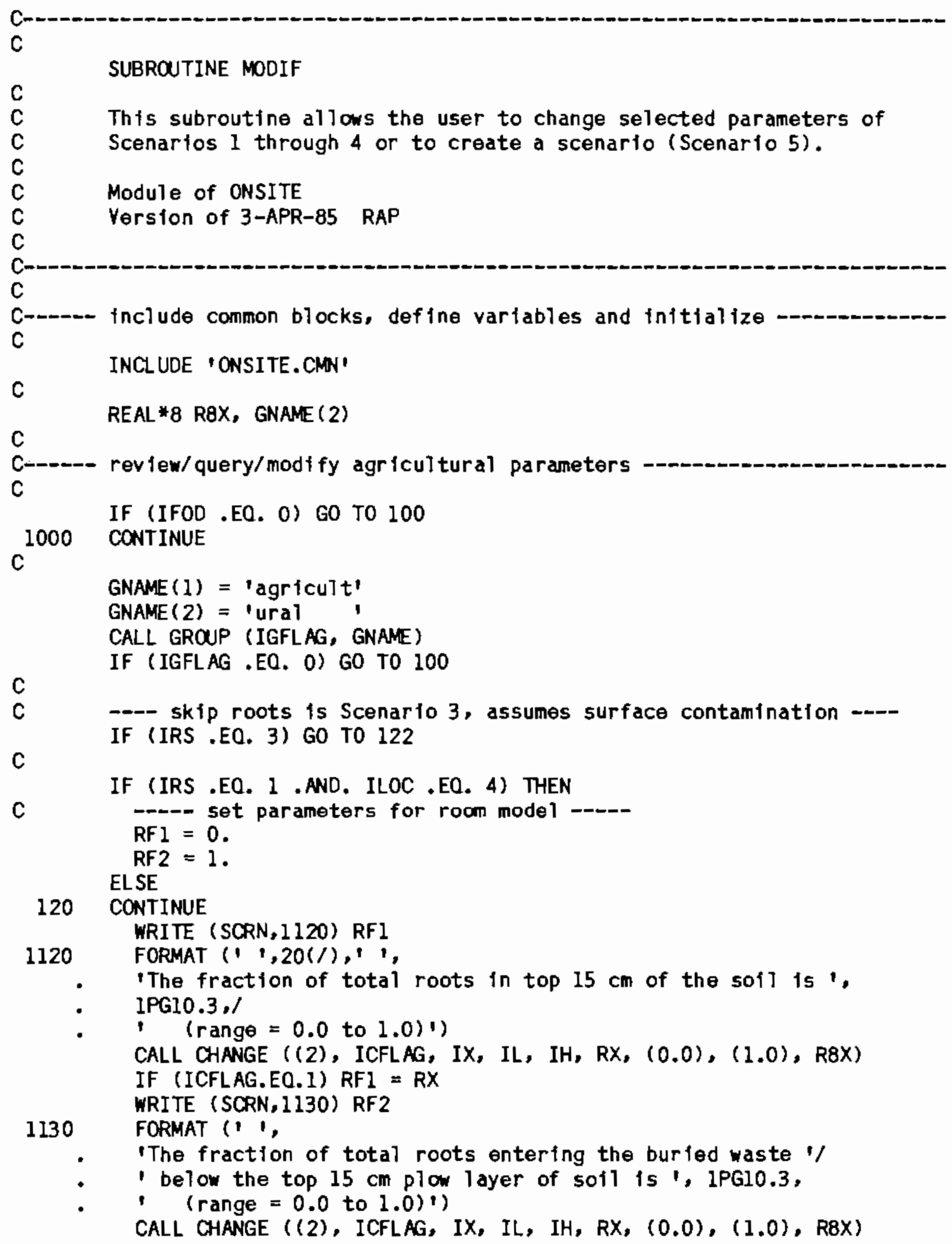


C

$$
R F=R F I+R F 2
$$

IF (RF .GT. 1.0) WRITE (SCRN,1140)

1140 FORMAT $(/ /, 11$, The sum of the previous two fractions cannot $1 /$

- ' be greater than 1.0: REENTER $1 ! 11)$

IF (RF .GT. 1.0) GO TO 120

ENDIF

C

122 CONTINUE

WRITE (SCRN,1166) IDT
1166 FORMAT $(1,20(/), 1$,
IThe R.G. 1,109 diet

- 'The R.G. 1.109 diet ralsed onsite may be elther:1//

- $9 X, 11$ - Total diet

- $9 x, 12$ - Vegetable product diet (plant only)\%,

- 9x, ' 3 - Anfmal product diet (milk, eggs, and meat only)',

- $/ 1,1$ The defautt selection is $1,12,1,1)$

CALL CHANGE ((1), ICFLAG, IX, (1), (3), RX, RL, RH, R8X)

C IF (ICFLAG.EQ.I) IDT = IX

1160 FORMAT $(1,20(1), 1$,

$$
\text { IF (FRSIZ .LT. 1.0) GOTO } 1161
$$

WRITE (SCRN, 1160) RPF 2

- 'The fraction of the selected diet grown on the site ',

- ' Is ', IPGl0.3," (range $=0.0$ to 1.0 )')

CALL CHANGE ((2), ICFLAG, IX, IL, IH, RX, $(0.0),(1.0), \mathrm{R} 8 X)$ IF (ICFLAG.EQ. I) RPF2 $=\mathrm{RX}$

c

$$
\text { CONTINUE }
$$

1161

IF (IWAT .EQ. 0) GOTO 100

WRITE (SCRN, I100) RIRR

1100 FORMAT (' ',

- The irrigation rate in liters per square meter per month is '

- IPGI0.3,I

- (range $=0.0$ to 1000.$)$ )

CALL CHANGE ( (2), ICFLAG, IX, IL, IH, RX, (0.0), (1000.0), R8X)

C

IF (ICFLAG.EO.1) RIRR $=R X$

IF (RIRR .EQ. 0.0$)$ GO TO 110

$$
\text { WRITE (SCRN,1110) IMO }
$$

FORMAT (',

- The number of months per year that crops are frrigated is 1 ,

- $\quad 12,1$

- $\quad$ (range $=0$ to 12$) "$ )

CALL CHANGE ((1), ICFLAG, IX, (0), (12), RX, RL, RH, R8X) IF (ICFLAG.EQ.I) IMO $=I X$

C

110 CONTINUE

WRITE (SCRN,11Il) IRR 
1111 FORMAT (',

- The number of years prior to the beginning of dose "

- calculations that irrigation accumulates radionucifides"/

- ' is ', I4,' (range = 0 to 1000)')

CALL CHANGE ( (1), ICFLAG, IX, (0), (1000), RX,RL, RH,R8X) IF (ICFLAG.EO.1) IRR=IX

100 CONTINUE

C----- revtew/query/modffy external exposure parameters

C

IF (IEXT .EQ. 0 .AND. ISUR .EQ. 0) GO TO 200

$\operatorname{GNAME}(1)=$ 'ext. exp'

$\operatorname{GNAME}(2)=$ 'osure

CALL GROUP (IGFLAG, GNAME)

IF (IGFLAG .EQ. O) GO TO 200

IF (ISUR .EO. O) GO TO 210

WRITE (SCRN, 1210) I22

1210 FORMAT (' $1,20(1), 11$,

- 'Did you use MAXI2 to generate a special externat exposure'/

- 'dose rate factor flle for this scenarlo? (default=',

. $\quad[1,1) 1,1 /$

- $15 X,{ }^{10}$ - no'/15X,'1 - yes')

CALL CHANGE ((1), ICFLAG, IX, (0), (1), RX,RL,RH,R8X)

IF (ICFLAG.EO. I) I22 = IX

210 CONTINUE

WRITE (SCRN,1200) XF2

1200 FORMAT (1 $1,20(1), 1$,

- The number of hours of exposure to external contamination ',

- I'per year is 1,1PGio.3," (range $=0.0$ to 8766.) i)

CALL CHANGE ((2), ICFLAG, IX, IL, IH, RX, (0.0), (8766.), R8X)

IF (ICFLAG.EO.1) XF2 = RX

C

WRITE (SCRN, 1201) IWD

1201 FORMAT (' ',20(/),' ',

- The waste density may be either: $1 / 1$

- 10X, $1-1.8 \mathrm{~g} / \mathrm{cu} \mathrm{cm} \mathrm{(5011)!}$

- 10X, ' $2-1.0 \mathrm{~g} / \mathrm{cu} \mathrm{cm} \mathrm{(water)'1}$

- 10X, $3-0.6 \mathrm{~g} / \mathrm{cu} \mathrm{cm}(0.5$ water + 0.1 carbon) $1 /$

- The default solection is ', I2, '.')

CALL CHANGE ((1), ICFLAG, IX, (1), (3), RX,RL,RH,R8X)

IF (ICFLAG.EO.1) IWD $=$ IX

200 CONTINUE

C-m- review/query/modify inhalation exposure parameters

C

IF (INHAL .EQ. O) GO TO 300

C
GNAME $(1)=$ "inhaTati"
$\operatorname{GNAME}(2)=$ 'on 1
CALL GROUP (IGFLAG, GNAME)
IF (IGFLAG .EO. O) GO TO 300
RIN $=$ RINH *8766. 


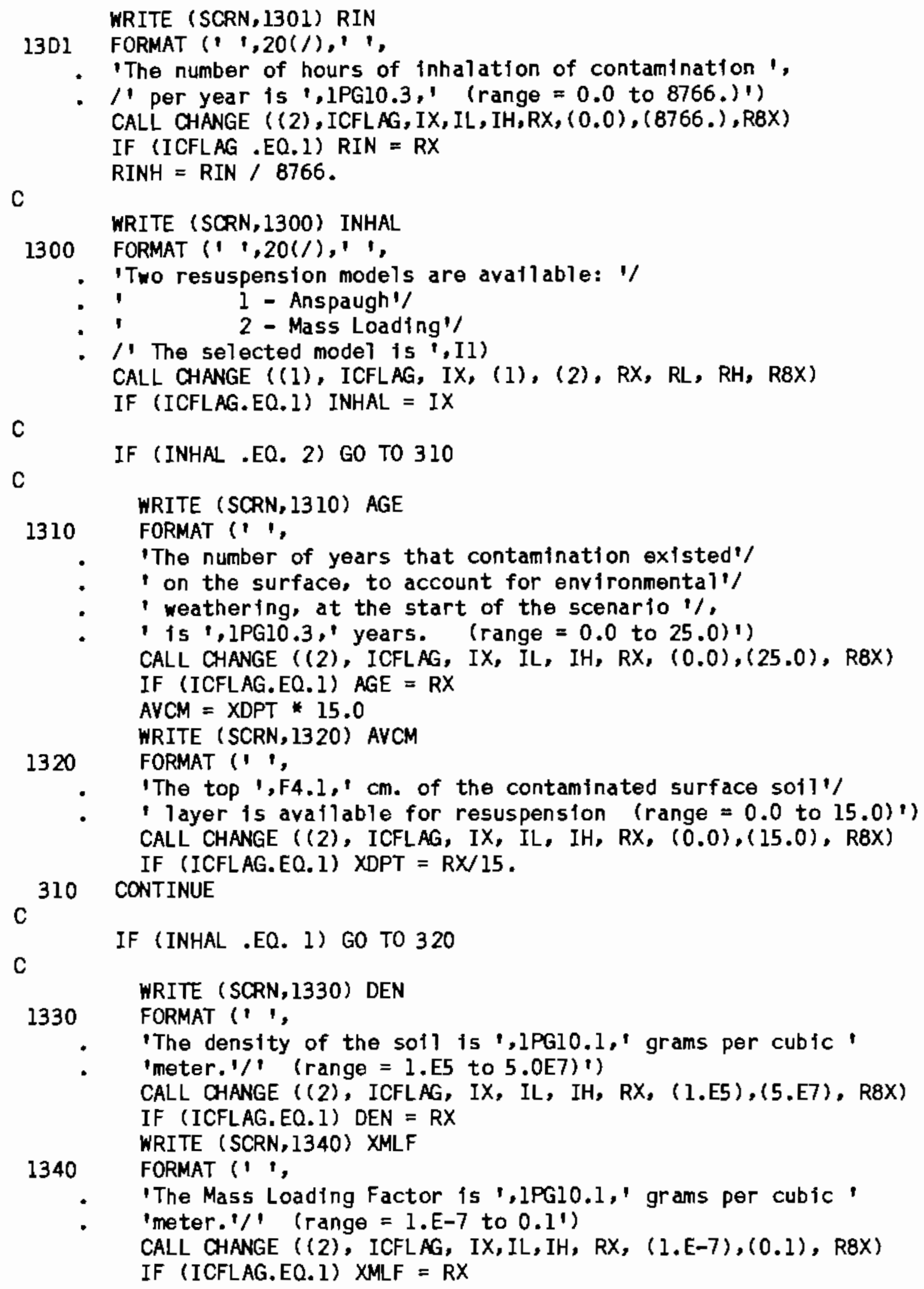




\section{APPENDIX B COMPUTER CODE LISTING - ONSITE}

\section{C}

320 CONTINUE

C

300 CONTINUE

C-- review/query/modify organ parameters

$\mathrm{C}$

$\operatorname{GNAME}(1)=$ 'organ,

GNAME (2) = '

CALL GROUP (IGFLAG, GNAME) IF (IGFLAG ,EO. O) GO TO 800

WRITE (SCRN, 1800) NORG

1800 FORMAT (' $1,20(/), 1$,

- 'The number of organs considered is $1,12,1$ ( $r$ ange $=1$ to 5$) 1$

- 'Total body must always be one of the selected organs.' CALL CHANGE ((1), ICFLAG, IX, (1), (5), RX, RL, RH, R8X)

C IF (ICFLAG.E0.1) NORG = IX

DO $810 I=1$, NORG

WRITE (SCRN,1810)

WRITE (SCRN,1B12)

WRITE (SCRN,1811) I, KORG(I)

1810 FORMAT (' ',

- The avaltable organs are: '//

- 1-Total body 9-Adrenats

1-2-Body water 10-Testes 18-Heart'/

- 3-Kidneys ll-ovaries 19-GI'/

- 4-Liver 12-Skin 20-Stomach"

- '5-Spleen 13-Bratn 21-Small intestine')

1812 FORMAT (' ',

- 6-Bone 14-Muscle 22-Upper large intestine"/

- 17-Fat 15-Prostrate 23-Lower large intestine\%

- ' 8-Lungs l6-Thyroid'//

- 'The ONSITE dose rate factor files have data on (1)total",

- 'body, (6)bone,"I

- ' (8) Tungs, (16) thyrotd, and (23)LLI. If you ish to use',

- 'other')

1811 FORMAT (' ',

- 'organs, a new environment must be created. See Section 2.21

- I of the Users Manuaj. 1//

- 'The current selection for organ no. ',I2,' is ',I2)

CALL CHANGE ((1), ICFLAG, IX, (1), (23), RX, RL, RH, RBX)

IF (ICFLAG.EQ.1) KORG(I) = IX

C

810 CONTINUE

800 CONTINUE

RETURN

C

END 


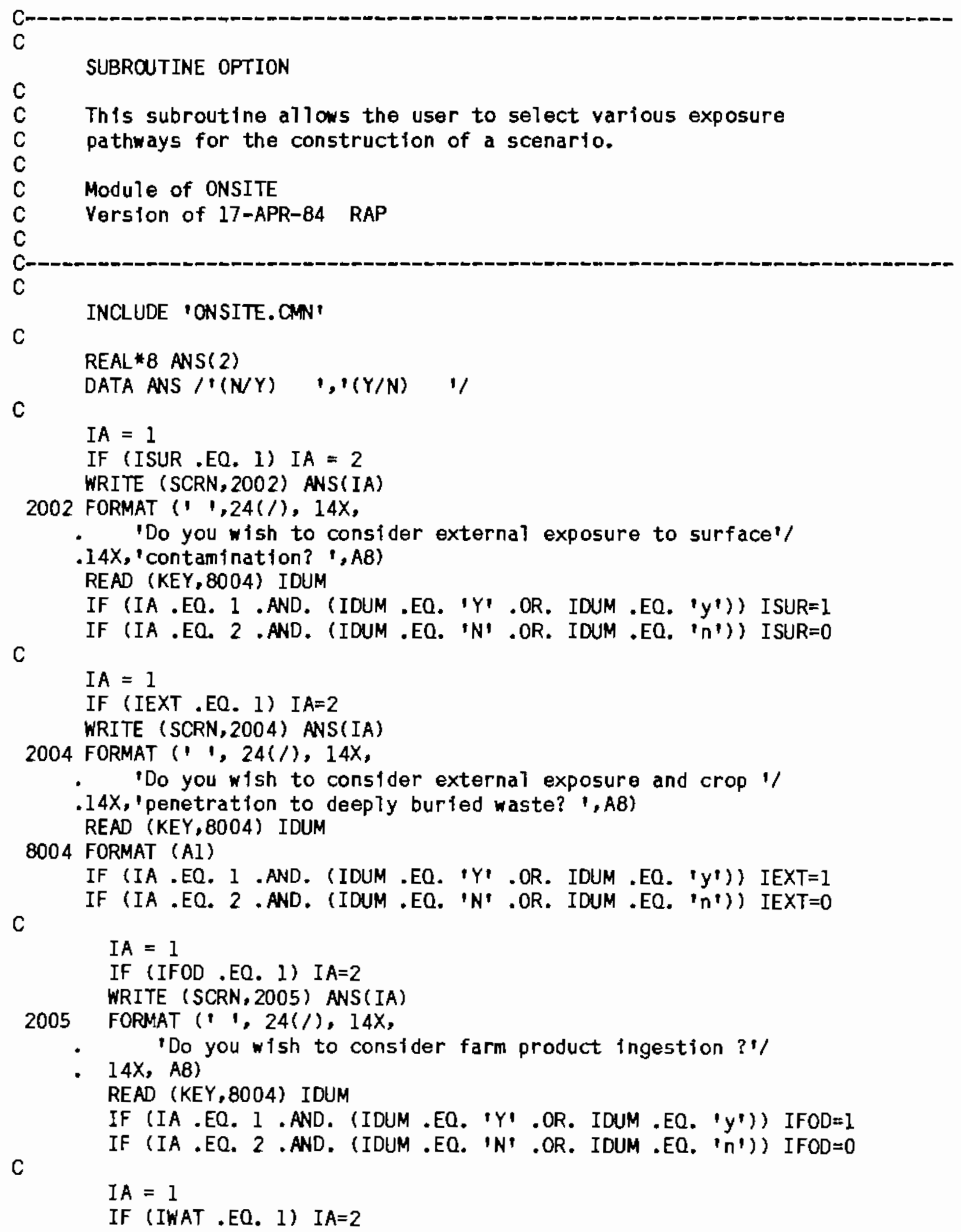




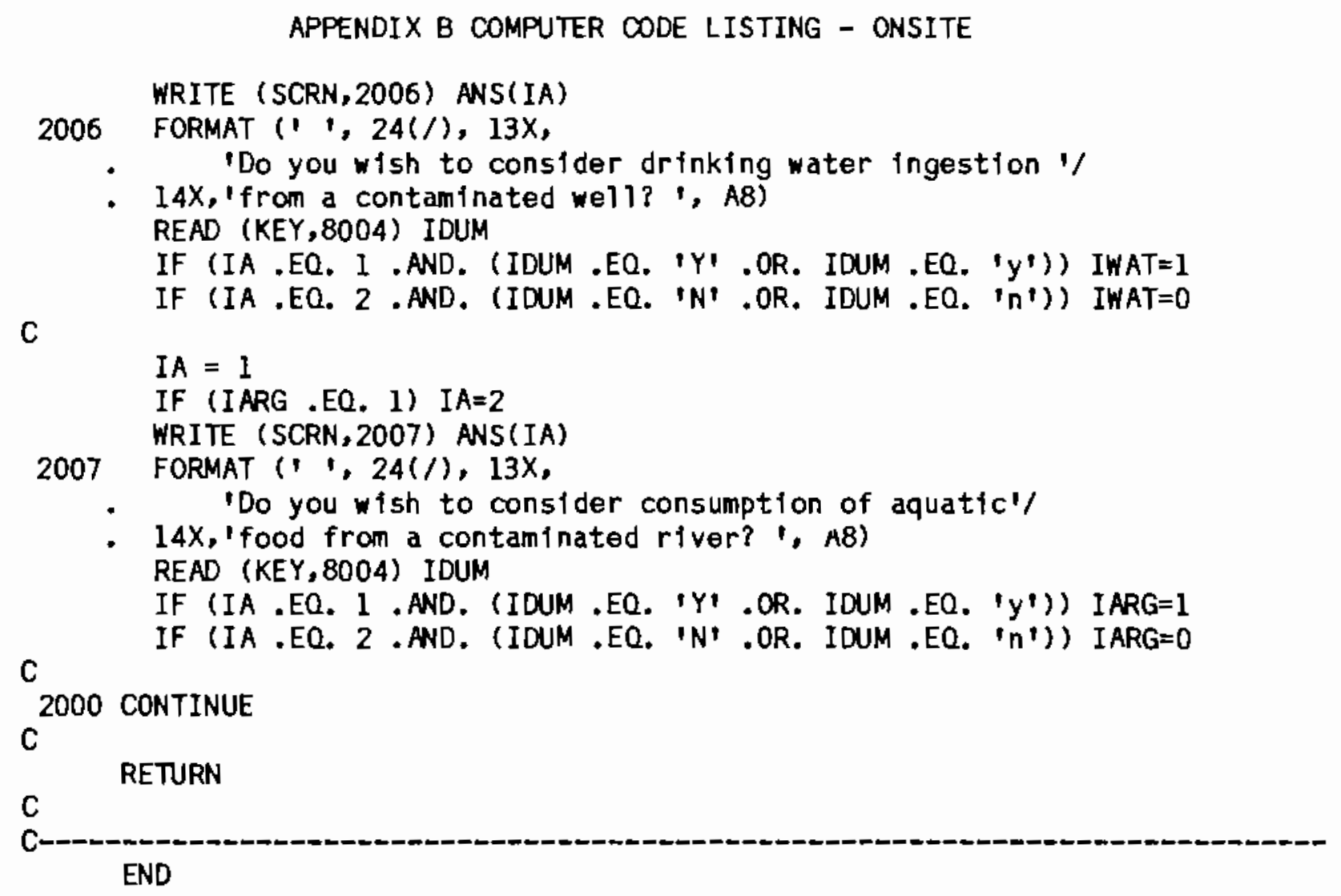






C

WRITE (SCRN, 1050) ELTI(I), AWI(I), (WHERE $(J, I A), J=1,3)$, 


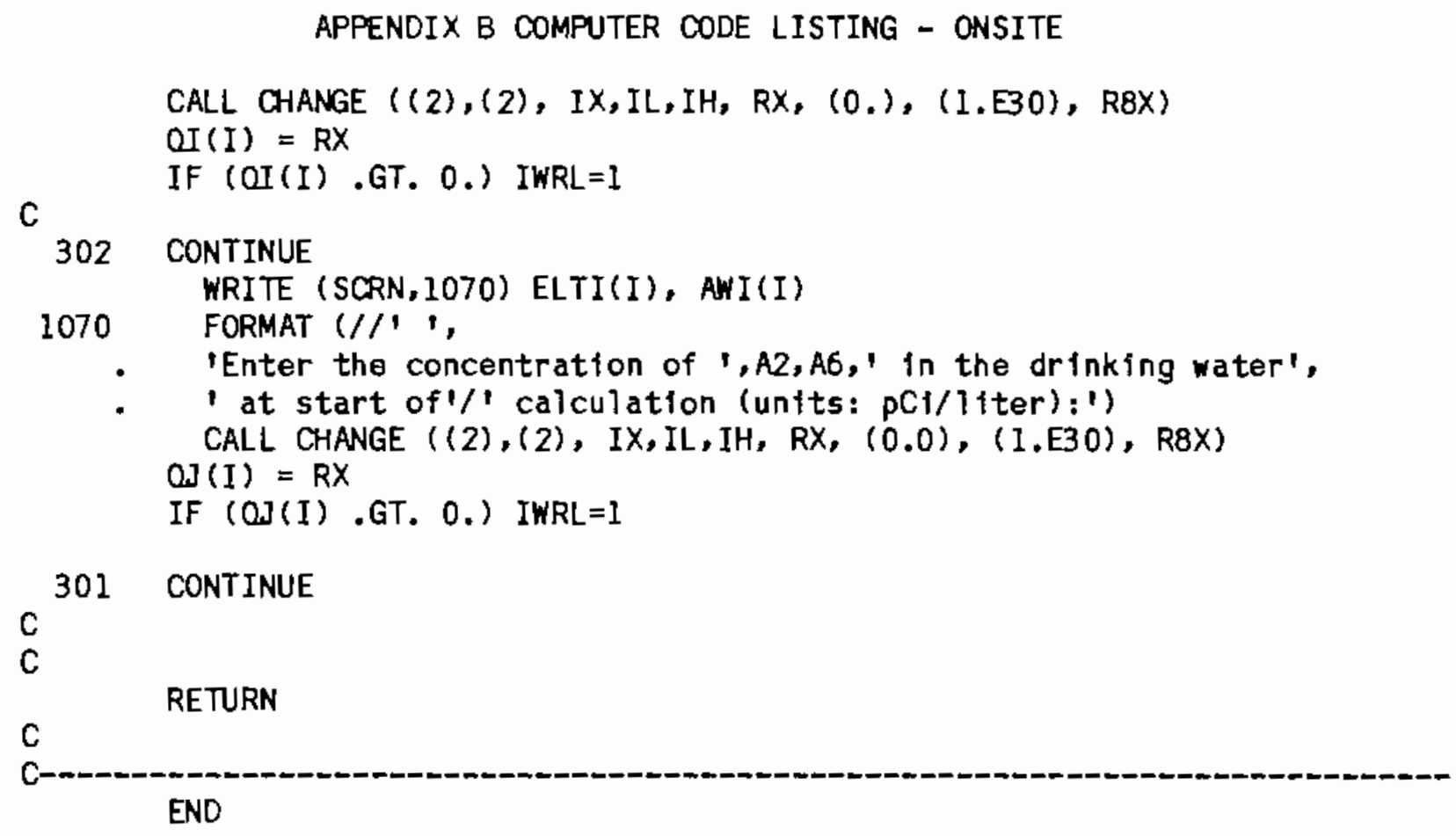




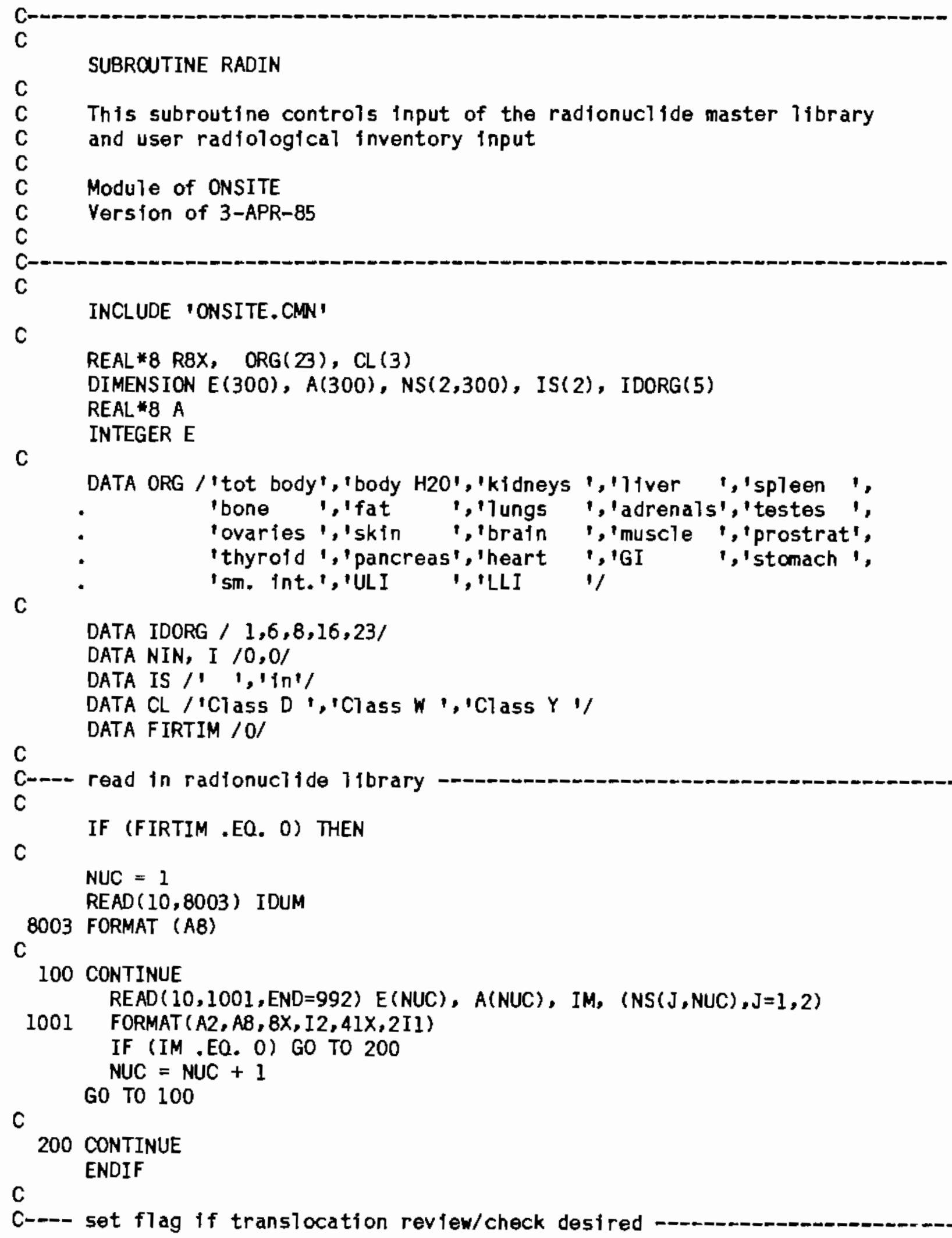


APPENDIX B COMPUTER CODE LISTING - ONSITE

C

IF (FIRTIM .EQ. O) THEN

$I T C=0$

C

IF (INHAL .EQ. 0 ) GO TO 410

WRITE (SCRN, 4101)

4101 FORMAT (' $1,20(/), 1$,

- 'Do you wish to review and/or change solubility classification'

- / for each organ for each radionuclide. The default assump-i

- " tion is elements are insoluble for lung and soluble for alt"

- /' other organs. (N/Y)')

READ (KEY, 8001) IDUM

IF (IDUM .EQ. 'Y',OR. IDUM .EQ. ' $Y$ ') ITC = I

410 CONTINUE

ENDIF

C

C-- test if this is original or additional inventory and set flags -.....--

C

IF (FIRTIM ,EO. O) THEN

$N I N=0$

$I=0$

ELSE

$I=N I N$

$\mathrm{C}$

ENDIF

C---- Inttlalize quantity arrays

C

IF (FIRTIM .EQ. O) THEN

DO $61010=1,100$

$Q(I O)=0$.

$O I(I O)=0$.

$a J(I Q)=0$.

$O K(I O)=0$.

610 CONTINUE

ENDIF

C

C--- display ilst of radionuclides

CALL RDLIST $(E, A)$

C

C---- signal beginning of inventory input

$\mathrm{C}$

208 CONTINUE

WRITE (SCRN, 1100)

1100 FORMAT (' $1,20(/), 1$ ',

- The following questions pertain to the radionuclide "/

- Inventory. After inputting the inventory, enter'/

- " "99" for element name to signal to the program that '/

- 'you are finished.1//, '1,70(1/1)//

- Press <return> when you have finished reading: 1) 
APPENDIX B COMPUTER OODE LISTING - ONSITE

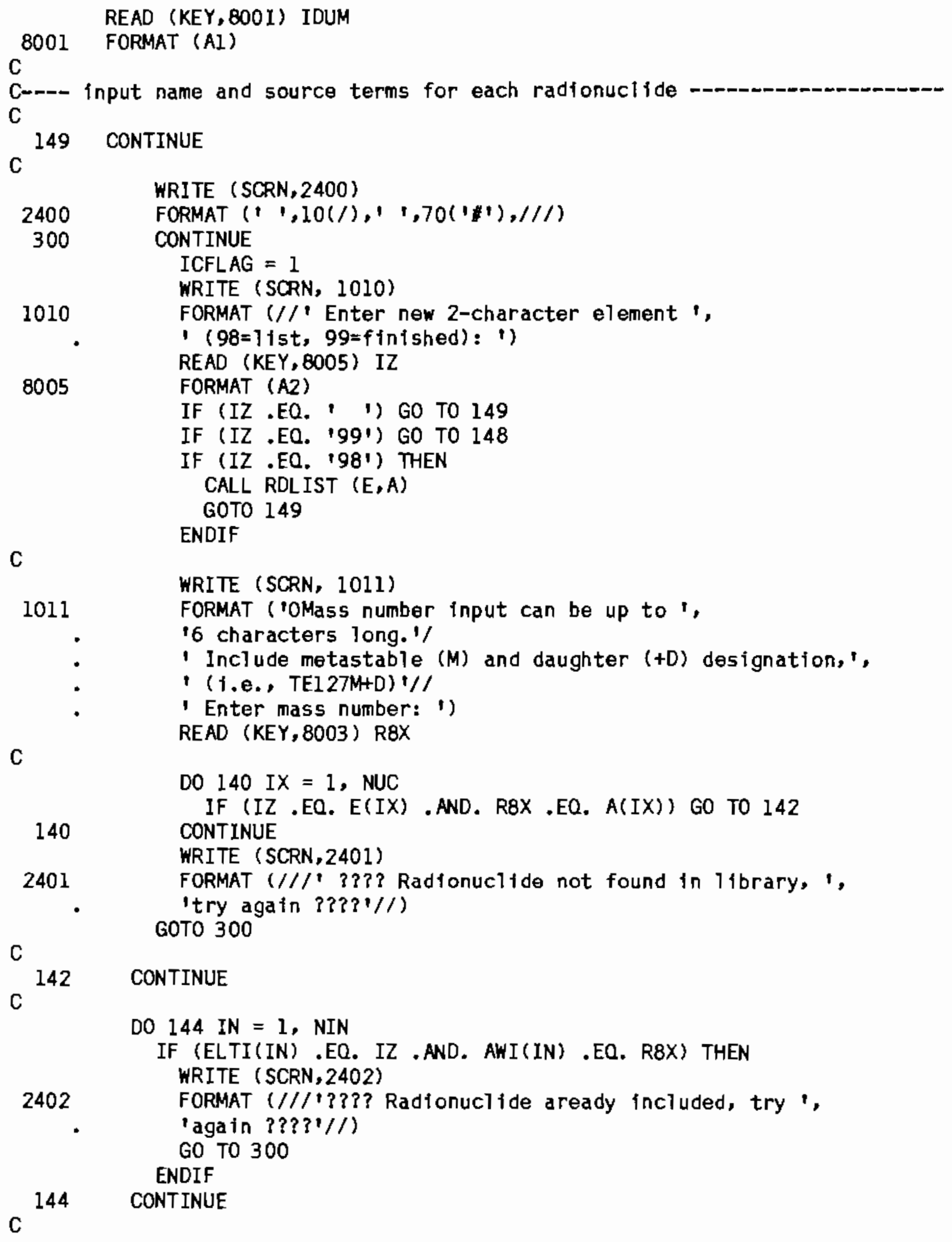




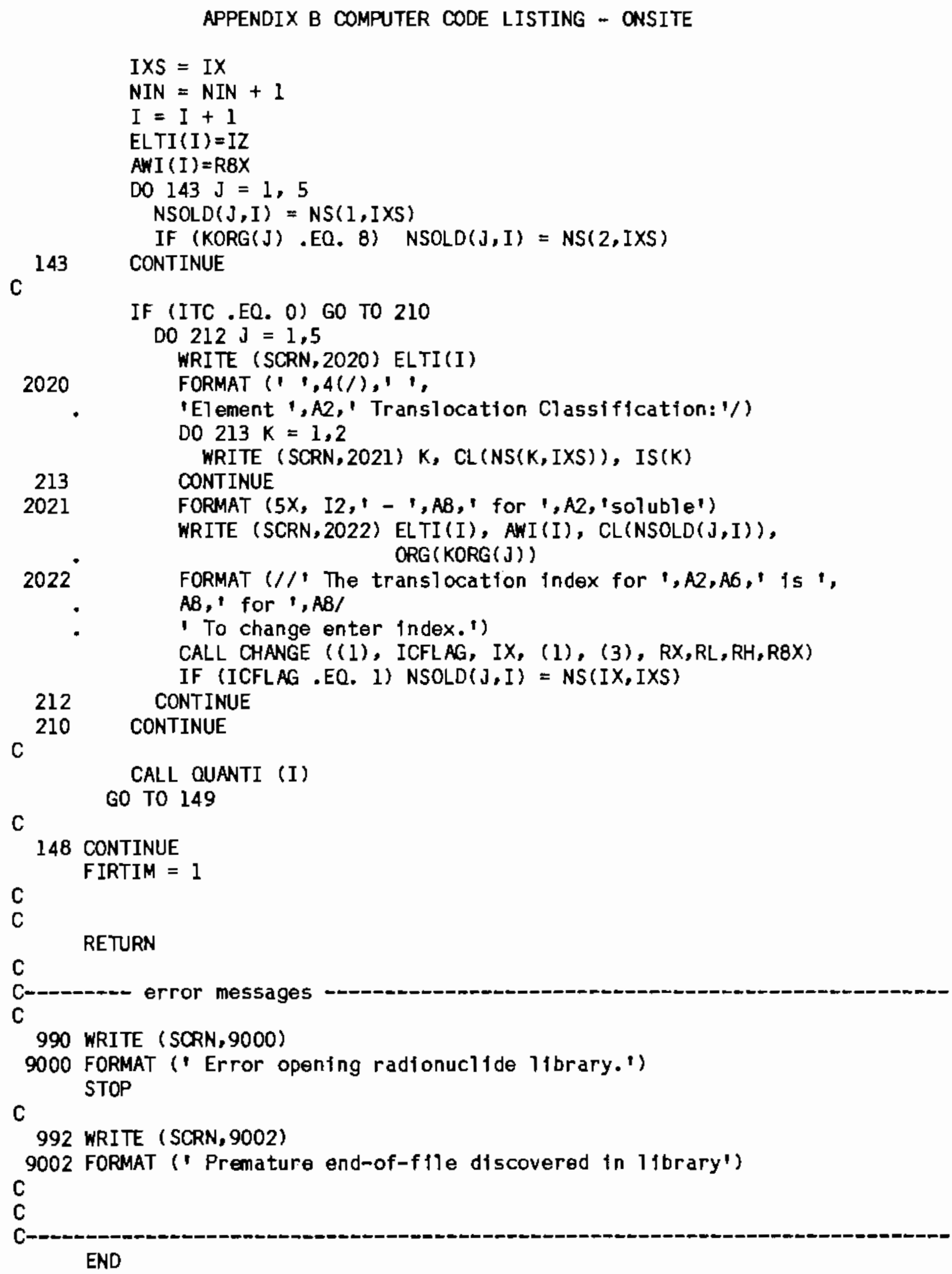




\section{APPENDIX B COMPUTER CODE LISTING - ONSITE}

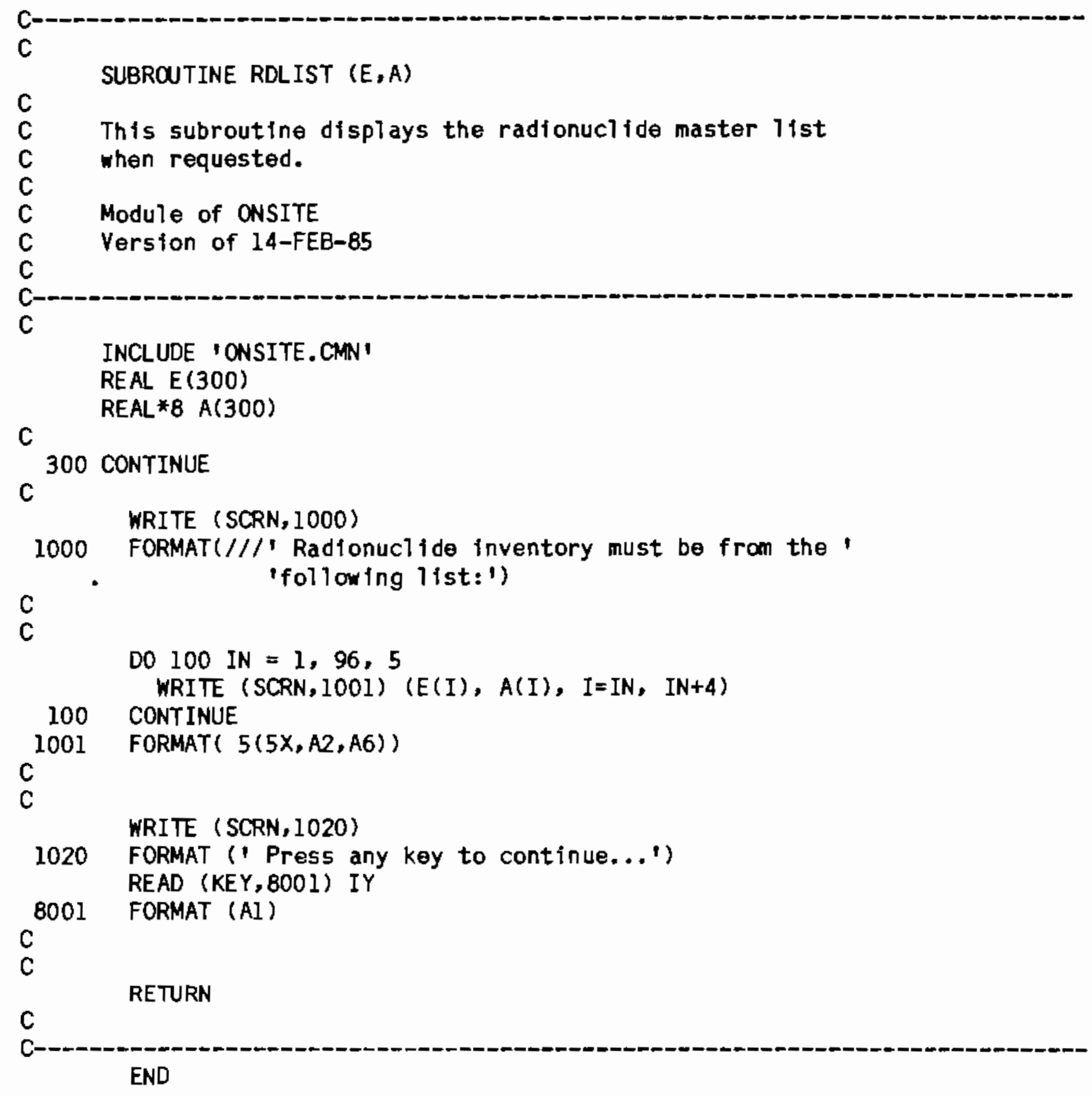


APPENDIX B COMPUTER CODE LISTING - ONSITE

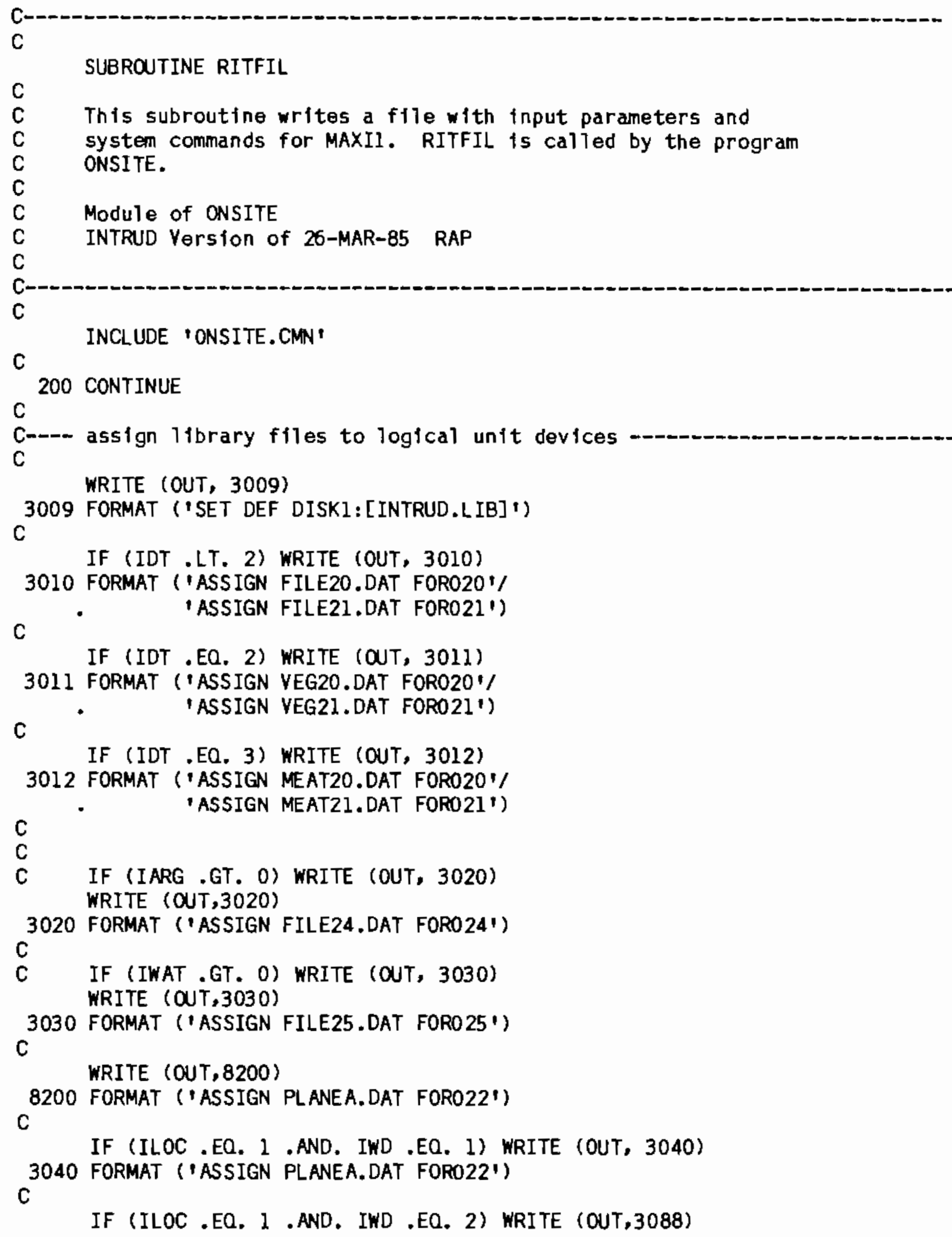


APPENDIX B COMPUTER CODE LISTING - ONSITE

3088 FORMAT ('ASSIGN PLANEB.DAT FORO22')

C

IF (ILOC .EQ. I .AND. IWD .EQ. 3) WRITE (OUT,3089)

3089 FORMAT ('ASSIGN PLANEC.DAT FORO22')

C

WRITE (OUT, 8201)

8201 FORMAT ('ASSIGN YOLSOURCA.DAT FORO 27')

C

IF (ILOC .EQ. 2 .AND. IWD .EQ. 1) WRITE (OUT, 3044)

3044 FORMAT ('ASSIGN VOLSOURCA.DAT FORO 27")

C

IF (ILOC .EQ. 2 .AND. IWD .EO. 2) WRITE (OUT, 3031)

3031 FORMAT ('ASSIGN YOLSOURCB.DAT FORO 27')

C

IF (ILOC .EO. 2 .AND. IWD .EQ. 3) WRITE (OUT, 3032) 3032 FORMAT ("ASSIGN VOLSOURCC.DAT FORO27')

C

C

IF (ILOC .EQ, 3 ,AND. IWD .EQ. 1) WRITE (OUT, 3041) 3041 FORMAT ('ASSIGN BURIEDHFA.DAT FORO27')

C

IF (ILOC .EO, 3 .AND. IWD .EO. 2) WRITE (OUT, 3033) 3033 FORMAT ('ASSIGN BURIEDHFA.DAT FORO 27 ')

C

IF (ILOC .EQ. 3 .AND. IWD .EO. 3) WRITE (OUT, 3034) 3034 FORMAT ('ASSIGN BURIEDHFB.DAT FORO 27')

C

$\mathrm{C}$

IF (ILOC .EQ. 4 .AND. IWD .EQ. 1) WRITE (OUT, 3042) 3042 FORMAT ('ASSIGN BURIEDIA.DAT FORO 27')

C

IF (ILOC .EQ. 4 .AND. IWD .EQ. 2) WRITE (OUT, 3035) 3035 FORMAT ('ASSIGN BURIEDIB.DAT FORO 27')

C

IF (ILOC .EQ. 4 .AND. IWO .EQ. 3) WRITE (OUT, 3036)

3036 FORMAT ('ASSIGN BURIEDIC.DAT FORO27')

C

IF (ILOC .EO. 5 .AND. IWD .EQ. 1) WRITE (OUT, 3037) 3037 FORMAT ('ASSIGN STOREDA.DAT FORO 27')

C

IF (ILOC .EQ. 5 .AND. IWD .EQ. 2) WRITE (OUT, 3038) 3038 FORMAT ('ASSIGN STOREDB. DAT FORO27')

C

IF (ILOC .EQ. 5 .AND. IWD .EO. 3) WRITE (OUT,3039)

3039 FORMAT ('ASSIGN STOREDC.DAT FORO27')

C

WRITE (OUT, 3050)

3050 FORMAT ('ASSIGN RMDLIB.DAT FORO10'\%

C

'ASSIGN FILE23.DAT FORO23') 


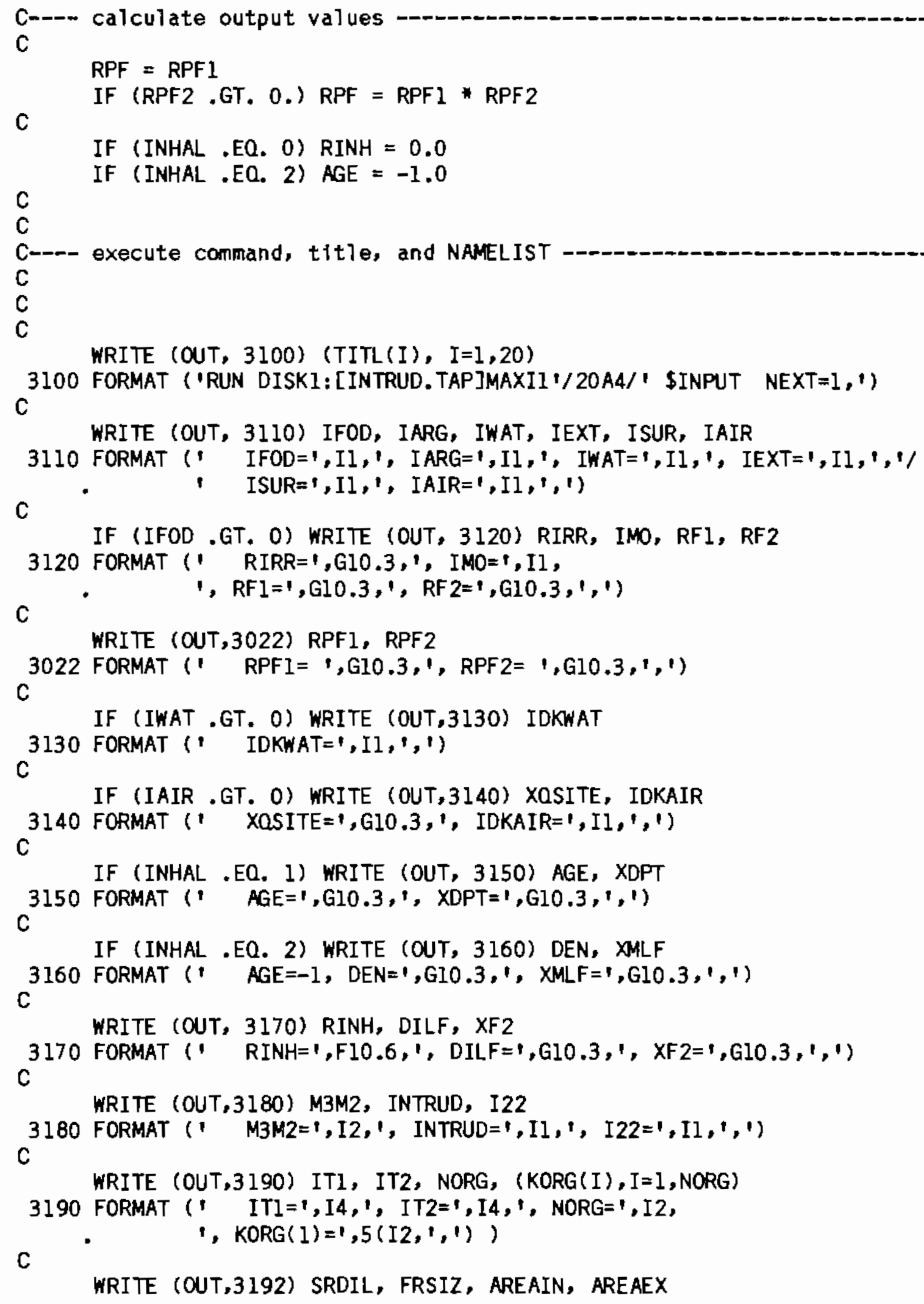




\section{APPENDIX B COMPUTER CODE LISTING - ONSITE}

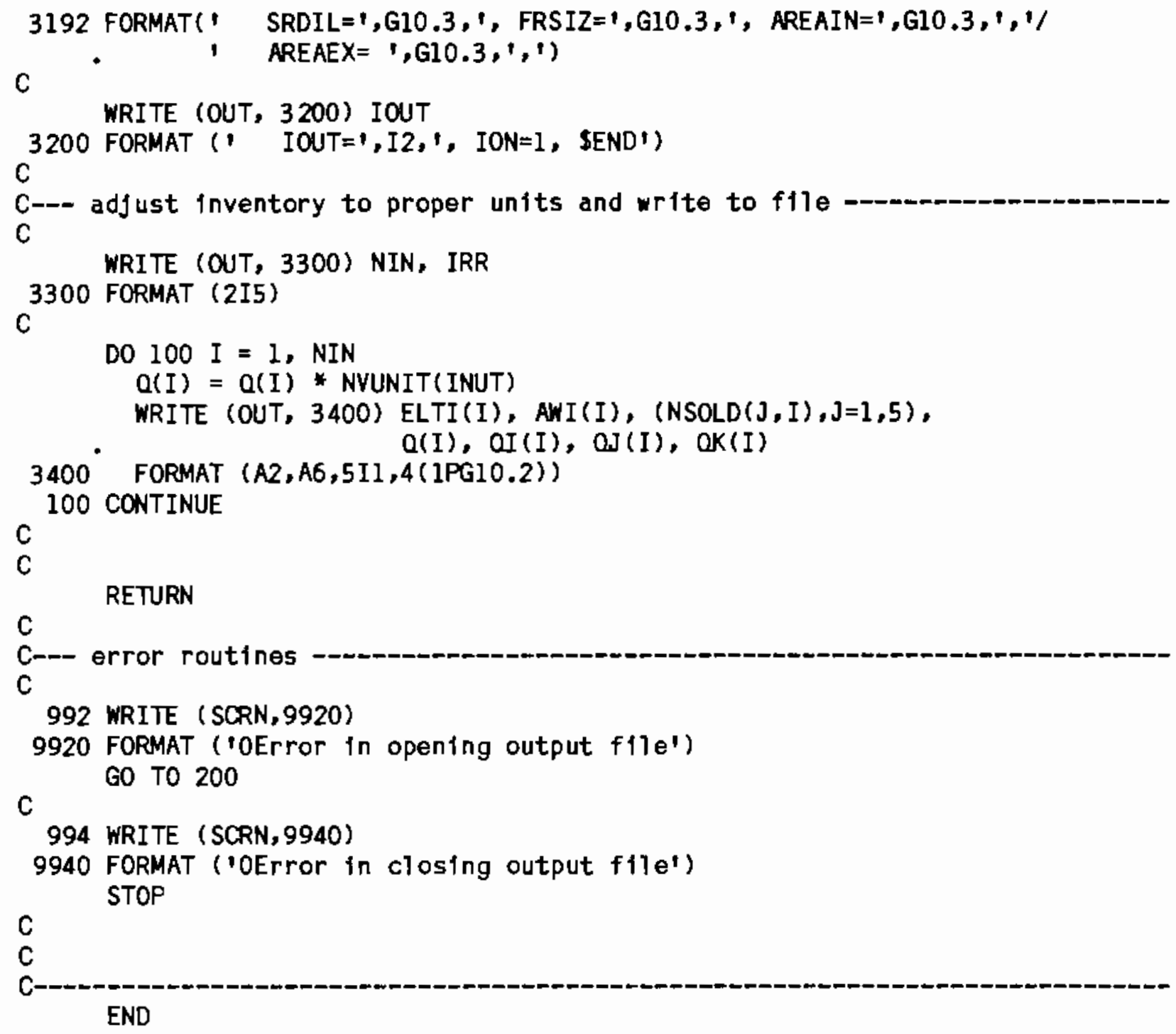


APPENDIX B COMPUTER CODE LISTING - ONSITE

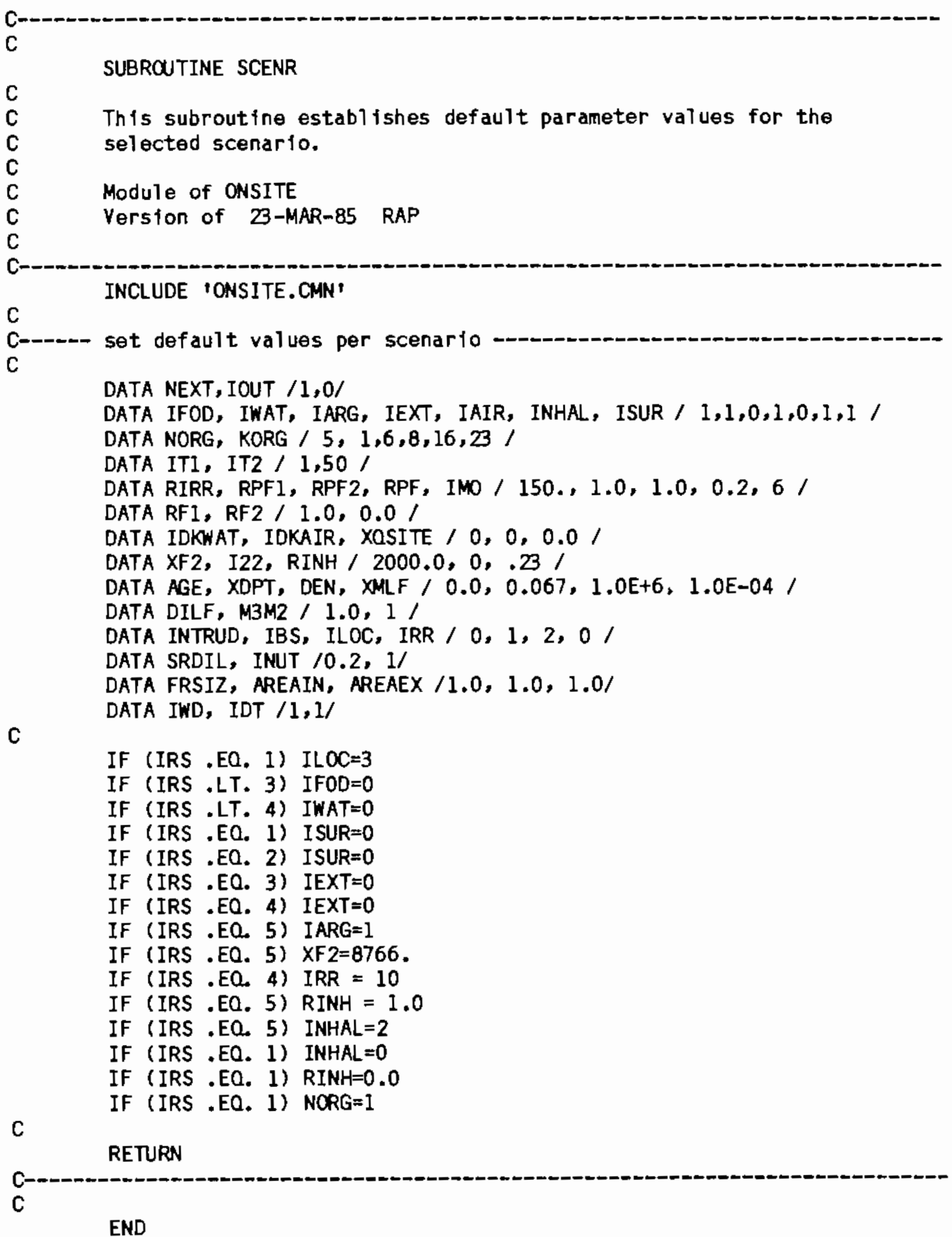

END 


\section{APPENDIX B COMPUTER CODE LISTING - ONSITE}

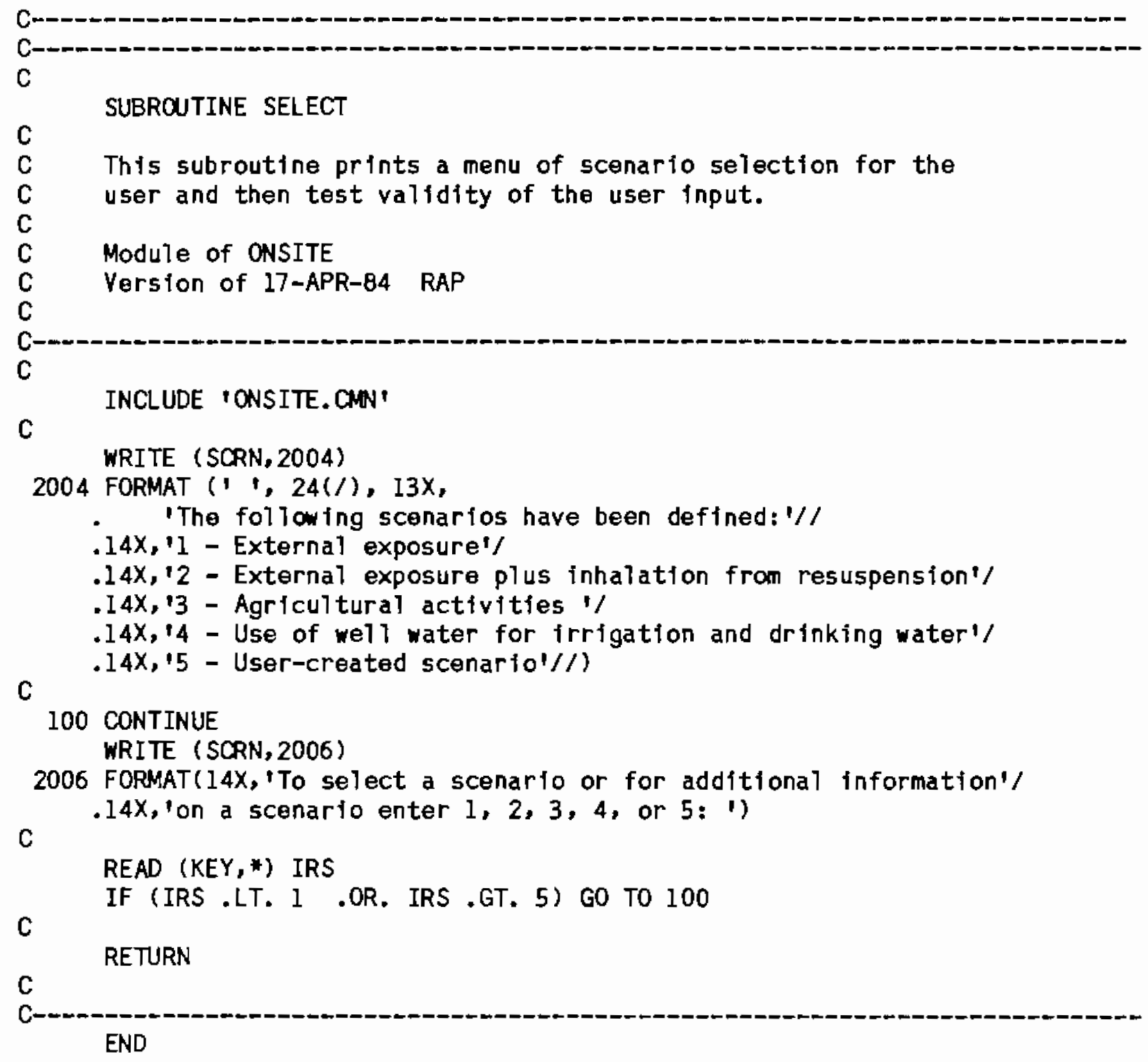


APPENDIX C

\section{EXIERNAL EXPOSURE DOSE RATE FACTOR LIBRARIES}

\section{CONTENTS}




APPENDIX C - EXTERNAL DOSE RATE FACTOR LIBRARIES - PLANEA

ONSITE/MAXI $15 \mathrm{CM}$. PLANE SOURCE ON SURFACE (DEN: CONCRETE/1.8) MR/HR 26-JUN-85

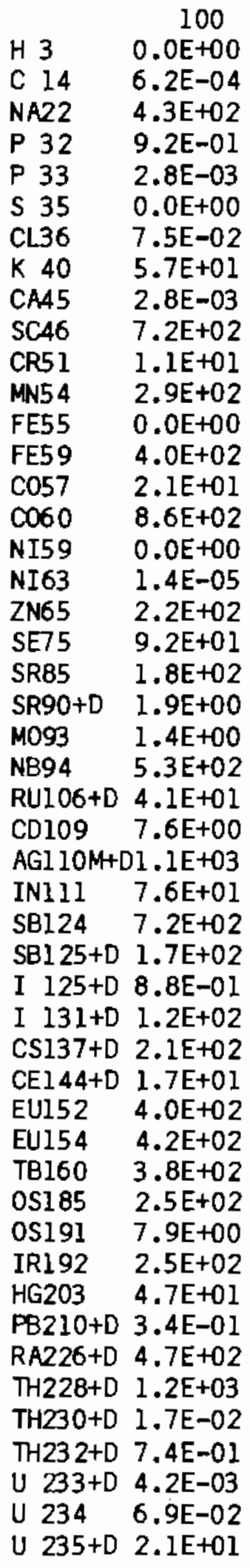

C. 1 
APPENDIX C - EXTERNAL DOSE RATE FACTOR LIBRARIES - PLANEA

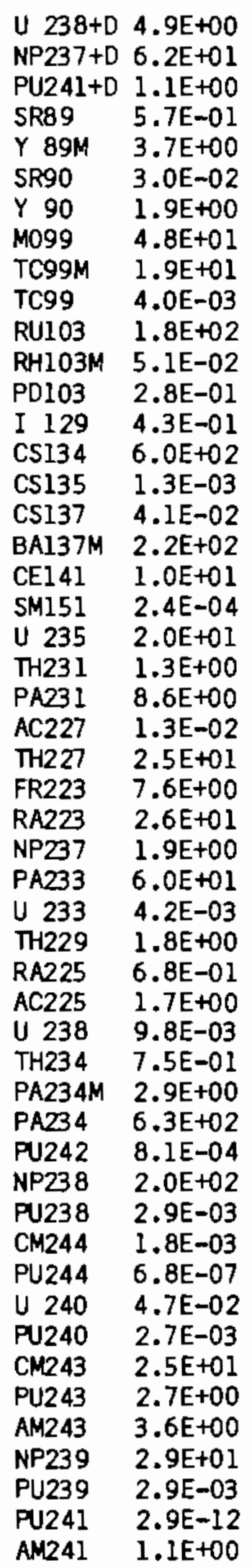

C.2 
APPENDIX C - EXTERNAL DOSE RATE FACTOR LIBRARIES - PLANEB

ONSITE/MAXI $15 \mathrm{CM}$. PLANE SOURCE ON SURFACE (DEN: WATER 1.0) MR/HR 26-JUN-85 100

$\mathrm{H} 3 \quad 0.0 \mathrm{E}+00$

C $145.2 \mathrm{E}-03$

$\mathrm{NA22} \quad 6.4 \mathrm{E}+02$

P $32 \quad 2.3 \mathrm{E}+00$

P $33 \quad 5.1 E-02$

$S 35 \quad 0.0 \mathrm{E}+00$

CL36 1.8E-02

K $40 \quad 8.8 E+01$

CA45 I.8E-02

$\mathrm{SC} 46 \quad 1.1 \mathrm{E}+03$

CR51 2.3E+01

MN54 4.8E+02

FE55 $0.0 \mathrm{E}+00$

FE59 $5.8 \mathrm{E}+02$

$\mathrm{C} 057 \quad 6.2 \mathrm{E}+0 \mathrm{l}$

C060 $1.3 E+03$

NI59 $\quad 0.0 E+00$

NI63 2.9E-13

ZN65 3.4E+02

SE75 2.2E+02

SRB5 $3.7 \mathrm{E}+02$

SR90+D 4.7E+00

MO93 1.3E+01

NB94 $9.4 \mathrm{E}+02$

RU106+D 8.0E+01

CD109 2.6E+01

$A G 110 M+D 1.8 E+03$

IN111 2.0E+02

SB124 1.2E+03

$\mathrm{SB} 125+\mathrm{D} \quad 3.4 \mathrm{E}+02$

I $125+D 1.2 \mathrm{E}+01$

I $131+\mathrm{D} 2.6 \mathrm{E}+02$

CS137+D 3.9E+02

CE144+D 3.4E+01

EU152 6.5E+02

EU154 6.8E +02

TB160 6.0E +02

OS185 4.7E+02

OS191 2.7E+01

IR192 5.4E+02

$\mathrm{HG} 203 \quad 1.2 \mathrm{E}+02$

$P B 210+D$ 1.4E +00

$\mathrm{RA} 226+\mathrm{D} 7.6 \mathrm{E}+02$

$\mathrm{TH} 228+\mathrm{D}$ 1.9E+03

$\mathrm{THZ} 30+\mathrm{D} 7.7 \mathrm{E}-02$

$\mathrm{TH} 232+\mathrm{D} \quad 4.2 \mathrm{E}+00$

U $233+\mathrm{D} 3.2 \mathrm{E}-02$

U $234 \quad 2.6 \mathrm{E}-01$

U 235+D 6.1E+0l 
APPENDIX C - EXTERNAL DOSE RATE FACTOR LIBRARIES - PLANEB

\begin{tabular}{ll} 
U 238+D & $9.3 \mathrm{E}+00$ \\
NP237+D & $1.4 \mathrm{E}+02$ \\
PU241+D & $6.4 \mathrm{E}+00$ \\
SR89 & $1.6 \mathrm{E}+00$ \\
Y $89 M$ & $5.3 \mathrm{E}+00$ \\
SR90 & $1.3 \mathrm{E}-01$ \\
Y 90 & $4.6 \mathrm{E}+00$ \\
M099 & $9.2 \mathrm{E}+01$ \\
TC99M & $5.5 \mathrm{E}+01$ \\
TC99 & $2.4 \mathrm{E}-02$ \\
RU103 & $3.7 \mathrm{E}+02$ \\
RH103M & $8.7 \mathrm{E}-01$ \\
PD103 & $4.7 \mathrm{E}+00$ \\
I 129 & $6.2 \mathrm{E}+00$ \\
CS134 & $1.1 \mathrm{E}+03$ \\
CS135 & $9.6 \mathrm{E}-03$ \\
CS137 & $1.6 \mathrm{E}-01$ \\
BA137M & $4.1 \mathrm{E}+02$ \\
CE141 & $3.2 \mathrm{E}+01$ \\
SM151 & $4.4 \mathrm{E}-03$ \\
U 235 & $5.6 \mathrm{E}+01$ \\
TH231 & $5.4 \mathrm{E}+00$ \\
PA231 & $1.9 \mathrm{E}+01$ \\
AC227 & $4.0 \mathrm{E}-02$ \\
TH227 & $6.0 \mathrm{E}+01$ \\
FR223 & $2.3 \mathrm{E}+01$ \\
RA223 & $6.4 \mathrm{E}+01$ \\
NP237 & $7.8 \mathrm{E}+00$ \\
PA233 & $1.3 \mathrm{E}+02$ \\
U 233 & $3.2 \mathrm{E}-02$ \\
TH229 & $5.8 \mathrm{E}+00$ \\
RA225 & $5.4 \mathrm{E}+00$ \\
AC225 & $5.0 \mathrm{E}+00$ \\
U 238 & $5.6 \mathrm{E}-02$ \\
TH234 & $2.6 \mathrm{E}+00$ \\
PA234M & $4.6 \mathrm{E}+00$ \\
PA234 & $1.0 \mathrm{E}+03$ \\
PU242 & $6.5 \mathrm{E}-03$ \\
NP238 & $2.9 \mathrm{E}+02$ \\
PU241 & $5.0 \mathrm{E}-11$ \\
AM241 & $6.4 \mathrm{E}+00$ \\
PU238 & $1.3 \mathrm{E}-02$ \\
CM244 & $1.5 \mathrm{E}-02$ \\
PU244 & $1.2 \mathrm{E}-05$ \\
U 240 & $2.7 \mathrm{E}-01$ \\
PU240 & $1.1 \mathrm{E}-02$ \\
CM243 & $6.7 \mathrm{E}+01$ \\
PU243 & $8.1 \mathrm{E}+00$ \\
AM243 & $1.4 \mathrm{E}+01$ \\
PP239 & $7.6 \mathrm{E}+01$ \\
\hline
\end{tabular}


APPENDIX C - EXTERNAL DOSE RATE FACTOR LIBRARIES - PLANEC



$\begin{array}{ll}\text { H } 3 & 0.0 \mathrm{E}+00\end{array}$

C $14 \quad 8.3 \mathrm{E}-03$

NA22 $\quad 7.8 \mathrm{E}+02$

P $32 \quad 3.1 E+00$

P $33 \quad 2.8 \mathrm{E}-02$

$535 \quad 0.0 \mathrm{E}+00$

CL36 4.0E-01

K $40 \quad 1.1 \mathrm{E}+02$

CA45 2.8E-02

$\mathrm{SC} 46 \quad 1.4 \mathrm{E}+03$

CR5 $12.9 \mathrm{E}+01$

MN54 $6.0 \mathrm{E}+02$

FE55 $0.0 E+0 D$

FE59 $\quad 7.2 \mathrm{E}+02$

C057 8.4E+01

C060 $\quad 1.6 \mathrm{E}+03$

NI59 $\quad 0.0 \mathrm{E}+00$

NI63 3.3E-04

ZN65 4.1E+02

SE75 $3.0 E+02$

SR85 4.8E+02

SR9O+D $\quad 6.3 \mathrm{E}+00$

M093 2.1E+01

NB94 1.2E+03

RU106+D 1.0E+02

CD109 3.6E+01

$A G 110 M+D 2.2 E+03$

INI11 2.7E+02

SB124 1.5E+03

SB1 25+D $4.3 \mathrm{E}+02$

I $125+D \quad 2.0 \mathrm{E}+01$

I $131+0 \quad 3.4 \mathrm{E}+02$

CS137+D 4.8E+02

CE144+D 4.4E+01

EUI52 8.0E+02

EU154 8.4E+02

TB160 7.5E+02

$0 \mathrm{~S} 185 \quad 5.8 \mathrm{E}+02$

OS191 3.8E+01

IR192 $6.9 \mathrm{E}+02$

HG203 1.5E+02

PB210+D 2.1E+00

RAZ26+D 9.4E+02

$\mathrm{TH} 228+\mathrm{D} \quad 2.2 \mathrm{E}+03$

TH230+D 1.1E-01

$T H 232+D \quad 6.1 E+00$

U $233+D \quad 4.9 E-02$

U $234 \quad 3.7 \mathrm{E}-01$

U $235+D \quad 8.4 E+01$ 
APPENDIX C - EXTERNAL DOSE RATE FACTOR LIBRARIES - PLANEC

$\begin{array}{ll}\text { U 238+D } & 1.2 E+01 \\ \text { NP237+D } & 1.8 E+02 \\ \text { PU241+D } & 9.5 E+00 \\ \text { SR89 } & 2.1 E+00 \\ \text { Y 89M } & 6.6 E+00 \\ \text { SR90 } & 1.9 E-01 \\ \text { Y 90 } & 6.1 E+00 \\ \text { M099 } & 1.1 E+02 \\ \text { TC99M } & 7.6 E+01 \\ \text { TC99 } & 3.6 E-02 \\ \text { RU103 } & 4.6 E+02 \\ \text { RH103M } & 1.5 E+00 \\ \text { PD103 } & 8.2 E+00 \\ \text { I 129 } & 1.0 E+01 \\ \text { CS134 } & 1.3 E+03 \\ \text { CS135 } & 1.5 E-02 \\ \text { CS137 } & 2.2 E-01 \\ \text { BA137M } & 5.1 E+02 \\ \text { CE141 } & 4.5 E+01 \\ \text { SM151 } & 7.6 E-03 \\ \text { U 235 } & 7.6 E+01 \\ \text { TH231 } & 8.0 E+00 \\ \text { PA231 } & 2.6 E+01 \\ \text { AC227 } & 5.5 E-02 \\ \text { TH227 } & 7.9 E+01 \\ \text { FR223 } & 3.1 E+01 \\ \text { RA223 } & 8.6 E+01 \\ \text { NP237 } & 1.1 E+01 \\ \text { PA233 } & 1.7 E+02 \\ \text { U 233 } & 4.9 E-02 \\ \text { TH229 } & 8.1 E+00 \\ \text { RA225 } & 8.1 E+00 \\ \text { AC225 } & 6.8 E+00 \\ \text { U 238 } & 8.1 E-02 \\ \text { TH234 } & 3.6 E+00 \\ \text { PA2234M } & 5.8 E+00 \\ \text { PA234 } & 1.3 E+03 \\ \text { PU242 } & 9.8 E-03 \\ \text { NP238 } & 3.7 E+02 \\ \text { PU238 } & 1.8 E-02 \\ \text { CM244 } & 2.2 E-02 \\ \text { PU244 } & 2.2 E-05 \\ \text { U 240 } & 5.0 E-01 \\ \text { PU240 } & 1.6 E-02 \\ \text { CM243 } & 9.0 E+01 \\ \text { PU243 } & 1.1 E+01 \\ \text { AM243 } & 2.1 E+01 \\ \text { NP239 } & 1.0 E+02 \\ \text { PU239 } & 1.6 E-02 \\ \text { PU241 } & 9.1 E-11 \\ \text { AM241 } & 9.5 E+00\end{array}$


APPENDIX C - EXTERNAL DOSE RATE FACTOR LIBRARIES - STOREDA

ONSITE/MAXI - STORED: $1.0 \mathrm{M}$ THICK FINITE SLAB (DEN: 5011 1.8) MR/HR 26-JUN-85 H 3 7.6E-15

C $14 \quad 1.0 \mathrm{E}-04$

NA22 $1.7 \mathrm{E}+02$

P $32 \quad 3.4 \mathrm{E}-01$

P $33 \quad 6.3 \mathrm{E}-04$

S $35 \quad 0.0 \mathrm{E}+00$

CL36 2.5E-02

K $40 \quad 2.2 \mathrm{E}+01$

CA45 $6.4 \mathrm{E}-04$

$\mathrm{SC} 46 \quad 2.8 \mathrm{E}+02$

CR5 1 4.1E+00

MN54 $1.1 \mathrm{E}+02$

FE55 $0.0 E+00$

FE59 $1.5 E+02$

C057 $\quad 8.2 E+00$

$0060 \quad 3.3 \mathrm{E}+02$

NI59 $0.0 \mathrm{E}+00$

NI63 1.2E-06

ZN65 8.7E+01

SE75 3.6E+Ol

SR85 7.0E+01

SR9O+D 7.3E-01

M093 1.3E-01

NB94 2.0E+02

RU106+D 1. $.6 E+01$

CD109 2.2E+00

AGI IOM+D4 .0E+02

INIII 2.9E+01

SB124 2.8E+02

SB1 25+D 6.4E+01

I $125+D \quad 7.4 \mathrm{E}-02$

I $131+D \quad 4.7 E+01$

CS137+D 7.7E+01

CE144+D $6.4 \mathrm{E}+00$

EU152 1.6E+02

EU154 1.6E+02

TB160 1.5E +02

OS185 9.3E+01

OS191 2.8E+00

IR192 $9.8 \mathrm{E}+01$

HG203 1.8E+01

PB210+D 1.0E-01

$\mathrm{RA} 226+\mathrm{D} 1.8 \mathrm{E}+02$

$\mathrm{TH} 228+\mathrm{D} \quad 4.9 \mathrm{E}+02$

$\mathrm{TH} 230+\mathrm{D}$ 4.7E-03

$\mathrm{TH} 232+\mathrm{D} 2.0 \mathrm{E}-01$

U Z33+D 6.4E-04

U $234 \quad 2.4 \mathrm{E}-02$

U $235+D \quad 8.0 E+00$ 
APPENDIX C - EXTERNAL DOSE RATE FACTOR LIBRARIES - STOREDA

$\begin{array}{ll}\text { U 238+D } & 1.8 E+00 \\ \text { NP237+D } & 2.4 E+01 \\ \text { PU241+D } & 3.0 E-01 \\ \text { SR89 } & 2.1 E-01 \\ \text { Y 89M } & 1.4 E+00 \\ \text { SR90 } & 9.5 E-03 \\ \text { Y 90 } & 7.2 E-01 \\ \text { M099 } & 1.8 E+01 \\ \text { TC99M } & 7.4 E+00 \\ \text { TC99 } & 1.0 E-03 \\ \text { RU103 } & 6.9 E+01 \\ \text { RH103M } & 4.0 E-03 \\ \text { PD103 } & 3.2 E-02 \\ \text { I 129 } & 3.8 E-02 \\ \text { CS134 } & 2.3 E+02 \\ \text { CS135 } & 2.6 E-04 \\ \text { CS137 } & 1.4 E-02 \\ \text { BA137M } & 8.2 E+01 \\ \text { CE141 } & 4.0 E+00 \\ \text { SM151 } & 1.8 E-05 \\ \text { U 235 } & 7.6 E+00 \\ \text { TH231 } & 3.9 E-01 \\ \text { PA231 } & 3.3 E+00 \\ \text { AC227 } & 5.0 E-03 \\ \text { TH227 } & 9.5 E+00 \\ \text { FR223 } & 2.7 E+00 \\ \text { RA223 } & 9.7 E+00 \\ \text { NP237 } & 5.6 E-01 \\ \text { PA233 } & 2.3 E+01 \\ \text { U 233 } & 6.4 E-04 \\ \text { TH229 } & 7.0 E-01 \\ \text { RA225 } & 7.3 E-02 \\ \text { AC225 } & 5.7 E-01 \\ \text { U 238 } & 2.6 E-03 \\ \text { TH234 } & 2.3 E-01 \\ \text { PA234M } & 1.1 E+00 \\ \text { PA234 } & 2.4 E+02 \\ \text { PU242 } & 8.6 E-05 \\ \text { NP238 } & 7.9 E+01 \\ \text { PU238 } & 9.1 E-04 \\ \text { CM244 } & 1.9 E-04 \\ \text { PU244 } & 7.9 E-09 \\ \text { U 240 } & 7.6 E-03 \\ \text { PU240 } & 8.9 E-04 \\ \text { CM243 } & 9.8 E+00 \\ \text { PU243 } & 8.8 E-01 \\ \text { AM243 } & 1.0 E+00 \\ \text { NP239 } & 1.1 E+01 \\ \text { PU239 } & 1.0 E-03 \\ \text { PU241 } & 2.9 E-14 \\ \text { AM241 } & 3.0 E-01 \\ & \end{array}$

C. 8 
APPENDIX C - EXTERNAL DOSE RATE FACTOR LIBRARIES - STOREDB

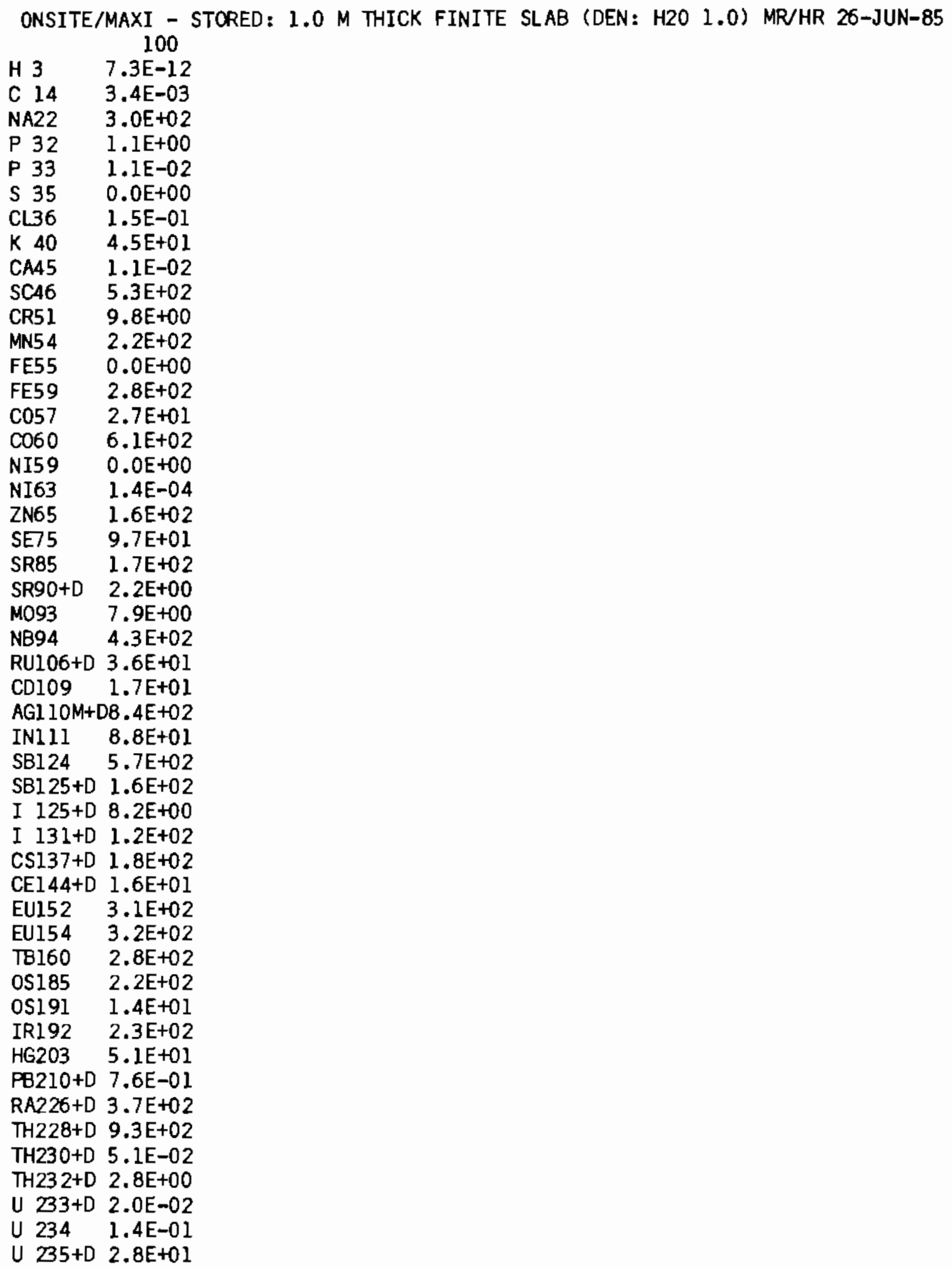

C.9 
APPENDIX C - EXTERNAL DOSE RATE FACTOR LIBRARIES - STOREDB

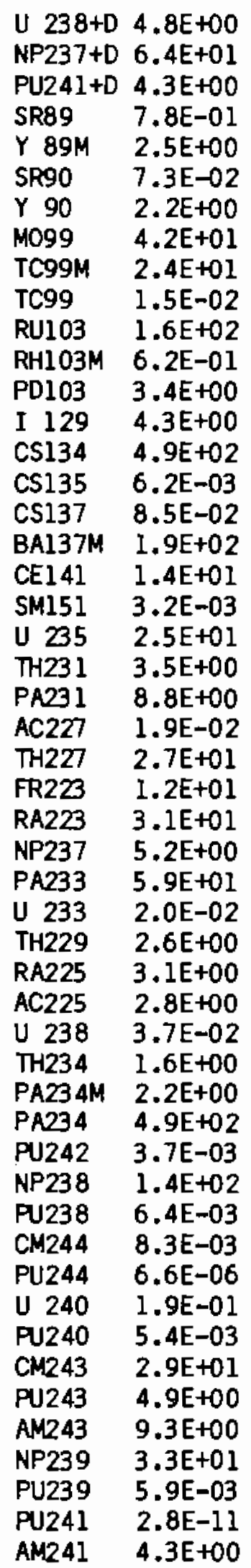

C. 10 
APPENDIX C - EXTERNAL DOSE RATE FACTOR LIBRARIES - STOREDC

ONSITE/MAXI - STORED: $1.0 \mathrm{M}$ FINITE SLAB (DEN: H20:CARBON/.5,.1) MR/HR 26-JUN-85 100

H $3 \quad 5.6 \mathrm{E}-14$

C $149.1 \mathrm{E}-04$

NA22 4.8E+02

P $32 \quad 1.5 \mathrm{E}+00$

P $33 \quad 4.3 \mathrm{E}-03$

$S 35 \quad 0.0 E+00$

CL36 1.3E-01

K $40 \quad 6.7 \mathrm{E}+01$

CA45 4.3E-03

SC46 8.3E+02

CR51 $1.6 \mathrm{E}+01$

MN54 3.6E+02

FE55 $0.0 \mathrm{E}+00$

FE59 4.4E+02

C057 4.4E+01

C060 9.5E+02

NI59 $0.0 \mathrm{E}+00$

NI63 2.3E-05

ZN65 2.5E+02

SE75 1.6E+02

SR85 2.7E+02

SR9O+D 3.0E+00

M093 $1.6 \mathrm{E}+00$

NB94 6.9E+02

RU106+D 5.7E+01

CD109 9.3E+00

AGl 10M+D1 .3E+03

INI11 $1.4 \mathrm{E}+02$

SB124 8.9E+02

SB1 25+D 2.4E+02

I $125+D 1.4 E+00$

I $131+\mathrm{D} 1.8 \mathrm{E}+02$

CS137+D 2.8E+02

CE144+D 2.3E+01

EU152 $4.8 \mathrm{E}+02$

EU154 5.0E+02

TB160 4.4E+02

$0 S 185 \quad 3.3 \mathrm{E}+02$

OS191 1.5E+01

IRI92 3.8E+02

HG203 8.1E+01

PB210+D 5.1E-01

$R A 226+D 5.7 E+02$

TH228+D 1.4E+03

TH230+D 2.8E-02

$\mathrm{TH} 232+\mathrm{D} \quad 1.6 \mathrm{E}+00$

U 233+D 5.8E-03

U $234 \quad 1.5 \mathrm{E}-01$

U $235+D \quad 4.1 E+01$ 
APPENDIX C - EXTERNAL DOSE RATE FACTOR LIBRARIES - STOREDC

$\begin{array}{ll}\text { U 238+D } & 5.8 E+00 \\ \text { NP237+D } & 9.2 E+01 \\ \text { PU241+D } & 2.4 E+00 \\ \text { SR89 } & 9.3 E-01 \\ \text { Y 89M } & 3.9 E+00 \\ \text { SR90 } & 5.2 E-02 \\ \text { Y 90 } & 3.0 E+00 \\ \text { MO99 } & 6.6 E+01 \\ \text { TC99M } & 3.9 E+01 \\ \text { TC99 } & 6.3 E-03 \\ \text { RU103 } & 2.6 E+02 \\ \text { RHI03M } & 1.0 E-01 \\ \text { PD103 } & 5.8 E-01 \\ \text { I 129 } & 7.2 E-01 \\ \text { CS134 } & 7.7 E+02 \\ \text { CS135 } & 2.0 E-03 \\ \text { CS137 } & 7.0 E-02 \\ \text { BA137M } & 3.0 E+02 \\ \text { CE141 } & 2.1 E+01 \\ \text { SM151 } & 5.0 E-04 \\ \text { U 235 } & 3.9 E+01 \\ \text { TH231 } & 1.9 E+00 \\ \text { PA231 } & 1.3 E+01 \\ \text { AC227 } & 2.5 E-02 \\ \text { TH227 } & 4.1 E+01 \\ \text { FR223 } & 1.3 E+01 \\ \text { RA223 } & 4.1 E+01 \\ \text { NP237 } & 2.7 E+00 \\ \text { PA233 } & 9.0 E+01 \\ \text { U 233 } & 5.8 E-03 \\ \text { TH229 } & 3.8 E+00 \\ \text { RA225 } & 6.8 E-01 \\ \text { AC225 } & 2.5 E+00 \\ \text { U 238 } & 2.1 E-02 \\ \text { TH234 } & 9.8 E-01 \\ \text { PA234M } & 3.3 E+00 \\ \text { PA234 } & 7.7 E+02 \\ \text { PU242 } & 8.2 E-04 \\ \text { NP238 } & 2.2 E+02 \\ \text { PU238 } & 5.2 E-03 \\ \text { CM244 } & 1.8 E-03 \\ \text { PU244 } & 8.4 E-08 \\ \text { U 240 } & 5.7 E-02 \\ \text { PU240 } & 5.0 E-03 \\ \text { CM243 } & 4.7 E+01 \\ \text { PU243 } & 3.6 E+00 \\ \text { AM243 } & 5.0 E+00 \\ \text { NP239 } & 5.4 E+01 \\ \text { PU239 } & 5.9 E-03 \\ \text { PU241 } & 2.1 E-13 \\ \text { AM241 } & 2.4 E+00 \\ & \end{array}$

C.12 
APPENDIX C - EXTERNAL DOSE RATE FACTOR LIBRARIES - VOLSOURCA

ONSITE/MAXI 1.0 M THICK VOL. SOURCE ON SURF. (DEN: CONCRETE/1.8) MR/HR 26-JUN-85 100

H $3 \quad 0.0 E+00$

C $14 \quad 6.2 \mathrm{E}-04$

NA22 5.1E+02

P $32 \quad 9.8 \mathrm{E}-01$

P $33 \quad 2.8 \mathrm{E}-03$

S $35 \quad 0.0 \mathrm{E}+00$

CL36 7.7E-02

K $40 \quad 7.0 \mathrm{E}+01$

CA45 2.8E-03

SC46 8.4E+02

CPSI 1.2E+01

MN54 3.3E+02

FE55 $0.0 E+00$

FE5 9 4.7E+02

C057 2.1E+01

C060 1.0E+03

NI59 $0.0 E+00$

NI63 1.4E-05

ZN65 2.7E+02

SE75 9.6E+01

SR85 2.0E+02

SR90+D 2.1E+00

M093 1.4E+00

NB94 6.0E+02

RU106+D 4.6E+01

CD109 7.6E+00

AG1 IOM+D1.2E+03

IN1II 7.8E+01

SB124 8.6E+02

$\mathrm{SB1} 25+\mathrm{D} 1.9 \mathrm{E}+02$

I $125+D$ 8.8E-01

I $131+0 \quad 1.3 \mathrm{E}+02$

CS137+D 2.3E+02

CE144+D 1.9E+01

EU152 4.7E+02

EU154 4.9E+02

TB160 4.4E+02

OSl $85 \quad 2.7 \mathrm{E}+02$

OSI91 8.0E+00

IR192 2.7E+02

HG203 4.9E+01

PB210+D 3.5E-01

RA226+D 5.5E+02

$\mathrm{TH} 228+\mathrm{D} \quad 1.6 \mathrm{E}+03$

TH230+D 1.7E-02

$\mathrm{TH} 232+\mathrm{D} \quad 7.4 \mathrm{E}-01$

U 233+D 4.2E-03

v $234 \quad 6.9 \mathrm{E}-02$

U 235+D 2.1E+01 
APPENDIX C - EXTERNAL DOSE RATE FACTOR LIBRARIES - VOLSOURCA

$\begin{array}{ll}\text { U 238+D } & 5.6 E+00 \\ \text { NP237+D } & 6.7 E+01 \\ \text { PU241+D } & 1.1 E+00 \\ \text { SR89 } & 6.1 E-01 \\ \text { Y 89M } & 4.4 E+0 D \\ \text { SR90 } & 3.0 E-02 \\ \text { Y 90 } & 2.1 E+00 \\ \text { MO99 } & 5.4 E+01 \\ \text { TC99M } & 1.9 E+01 \\ \text { TC99 } & 4.0 E-03 \\ \text { RU103 } & 2.0 E+02 \\ \text { RH103M } & 5.1 E-02 \\ \text { PD103 } & 2.8 E-01 \\ \text { I 129 } & 4.3 E-01 \\ \text { CS134 } & 6.7 E+02 \\ \text { CS135 } & 1.3 E-03 \\ \text { CS137 } & 4.2 E-02 \\ \text { BA137M } & 2.4 E+02 \\ \text { CE141 } & 1.0 E+01 \\ \text { SM151 } & 2.4 E-04 \\ \text { U 235 } & 2.0 E+01 \\ \text { TH231 } & 1.3 E+00 \\ \text { PA231 } & 9.3 E+00 \\ \text { AC227 } & 1.3 E-02 \\ \text { TH227 } & 2.6 E+01 \\ \text { FR223 } & 8.0 E+00 \\ \text { RA223 } & 2.7 E+01 \\ \text { NP237 } & 2.0 E+00 \\ \text { PA233 } & 6.5 E+01 \\ \text { U 233 } & 4.2 E-03 \\ \text { TH229 } & 1.9 E+00 \\ \text { RA225 } & 6.8 E-01 \\ \text { AC225 } & 1.7 E+00 \\ \text { U 238 } & 9.8 E-03 \\ \text { TH234 } & 7.6 E-01 \\ \text { PA234M } & 3.4 E+00 \\ \text { PA234 } & 7.2 E+02 \\ \text { PU242 } & 8.1 E-04 \\ \text { NP238 } & 2.4 E+02 \\ \text { PU238 } & 2.9 E-03 \\ \text { CM244 } & 1.8 E-03 \\ \text { PU244 } & 6.8 E-07 \\ \text { U 240 } & 4.7 E-02 \\ \text { PU234 } & 2.9 E-03 \\ \text { AM241 } & 1.9 E-12 \\ \text { CM243 } & 2.7 E-03 \\ \text { PU243 } & 2.6 E+01 \\ \text { AM243 } & 3.6 E+00 \\ \text { NP239 } & 3.0 E+01 \\ & \end{array}$


APPENDIX C - EXTERNAL DOSE RATE FACTOR LIBRARIES - VOLSOURCB

ONSITE/MAXI 1.0 M THICK VOL. SOURCE ON SURF. (DEN: WATER 1.0) MR/HR 26-JUN-85

H $3 \quad 0.0 \mathrm{E}+00$

C $14 \quad 5.4 \mathrm{E}-03$

$\mathrm{NA22} 9.6 \mathrm{E}+02$

P $32 \quad 2.8 E+00$

P $33 \quad 5.9 \mathrm{E}-02$

$S 35 \quad 0.0 E+00$

CL36 1.9E-02

K $40 \quad 1.5 \mathrm{E}+02$

CA45 $1.9 \mathrm{E}-02$

SC46 $\quad 1.6 \mathrm{E}+03$

CR51 2.8E+01

MN54 $6.8 \mathrm{E}+02$

FE55 $0.0 \mathrm{E}+00$

FE59 $\quad 8.7 \mathrm{E}+02$

C057 7.0E+01

C060 1.9E+03

NI59 $0.0 \mathrm{E}+00$

NI63 2.9E-13

ZN65 5.1E+02

SE75 2.7E+02

SR85 $4.8 \mathrm{E}+02$

SR $90+D \quad 5.8 E+00$

M093 1.3E+01

$\mathrm{NB9} 4 \quad 1.3 \mathrm{E}+03$

RU106+D 1.1E+02

CD109 2.8E+01

AG1 $10 M+D 2.6 E+03$

IN111 2.3E+02

SB124 1.8E+03

SB1 25+D 4.6E+02

I $125+D \quad 1.2 \mathrm{E}+01$

I $131+D \quad 3.3 E+02$

CS137+D 5.4E+02

CE144+D $4.6 \mathrm{E}+01$

EU152 $9.6 \mathrm{E}+02$

EU154 9.8E+02

TB160 8.6E+02

$0 S 185 \quad 6.5 \mathrm{E}+02$

OS191 3.0E+01

IR192 $6.7 \mathrm{E}+02$

HG203 1.4E+02

PB210+D 1.6E+00

RA226+D 1.2E+03

TH228+D $3.1 \mathrm{E}+03$

$\mathrm{TH} 230+\mathrm{D}$ 8.3E-02

$\mathrm{TH} 232+\mathrm{D} \quad 4.4 \mathrm{E}-00$

U $233+\mathrm{D} \quad 3.4 \mathrm{E}-02$

U $234 \quad 2.9 \mathrm{E}-01$

U 235+D 7.0E+01 
APPENDIX C - EXTERNAL DOSE RATE FACTOR LIBRARIES - VOL SOURCB

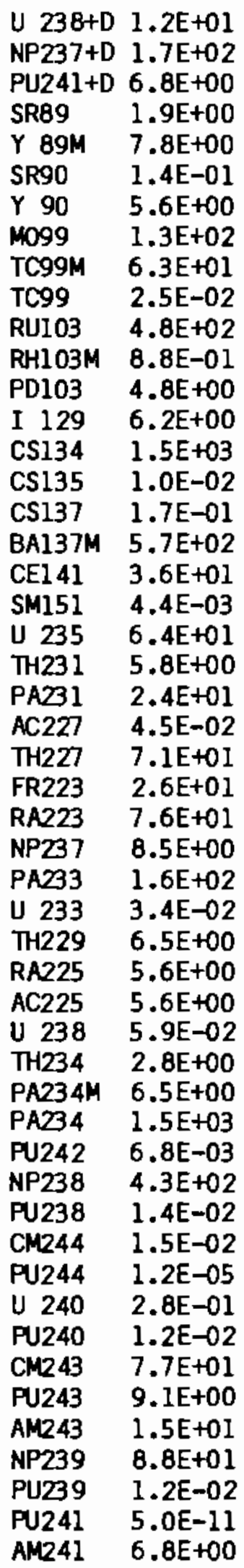


APPENDIX C - EXTERNAL DOSE RATE FACTOR LIBRARIES - VOLSOURCC

ONSITE/MAXI 1.0 M THICK YOL. SQURCE ON SURF. (DEN: H20:CARBON .5,.1) 26-JUN-85 100

H $3 \quad 0.0 E+00$

C $14 \quad 9.3 \mathrm{E}-03$

NA22 $1.6 \mathrm{E}+03$

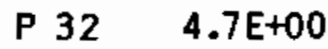

P $33 \quad 3.2 \mathrm{E}-02$

S $35 \quad 0.0 E+00$

$\mathrm{CL} 36 \quad 5.2 \mathrm{E}-01$

K $40 \quad 2.4 \mathrm{E}+02$

CA45 3.2E-02

SC46 2.7E+03

CR51 4.7E+01

MaN54 1.1E+03

FE55 $0.0 E+00$

FE59 $1.4 \mathrm{E}+03$

$\mathrm{CO57} \quad 1.2 \mathrm{E}+02$

$0060 \quad 3.2 \mathrm{E}+03$

NI59 $0.0 \mathrm{E}+00$

NI63 3.5E-04

ZN65 8.4E+02

$\mathrm{SE} 75 \quad 4.5 \mathrm{E}+02$

SR85 8.1E+02

SR90+D 9.7E+00

$1093 \quad 2.3 \mathrm{E}+01$

NB94 2.2E+03

RU106+D 1.8E+02

CD109 4.7E+01

AGIIOM+D4.3E+03

INIII $3.9 \mathrm{E}+02$

SB124 3.0E+03

SBI 25+D 7.5E+02

I $125+\mathrm{D} 2.1 \mathrm{E}+01$

I $131+\mathrm{D} \quad 5.5 \mathrm{E}+02$

CS137+D 8.8E+02

CE144+D 7.7E+01

EU152 1.6E+03

EU154 1.6E+03

TBl60 1.4E+03

$0 S 185 \quad 1.1 \mathrm{E}+03$

$0 \mathrm{~S} 191 \quad 5.0 \mathrm{E}+01$

IRI92 1.1E+03

$\mathrm{HG} 2032.3 \mathrm{E}+02$

$P B 210+D$ 2.7E+00

RA226+D 1.9E+03

TH228+D 5.0E+03

TH230+D 1.4E-01

$T H 232+D \quad 7.5 E+00$

U $233+0$ 5. $8 \mathrm{E}-02$

U $234 \quad 4.8 \mathrm{E}-01$

Uf $235+D$ 1.2E+02 
APPENDIX C - EXTERNAL DOSE RATE FACTOR LIBRARIES - VOL SOURCC

$\begin{array}{ll}\text { U 238+D } & 2.1 E+01 \\ \text { NP237+D } & 2.8 E+02 \\ \text { PU241+D } & 1.2 E+01 \\ \text { SR89 } & 3.1 E+00 \\ \text { Y 89M } & 1.3 E+01 \\ \text { SR90 } & 2.4 E-01 \\ \text { Y 90 } & 9.4 E+00 \\ \text { M099 } & 2.1 E+02 \\ \text { TC99M } & 1.1 E+02 \\ \text { TC99 } & 4.2 E-02 \\ \text { RU103 } & 8.0 E+02 \\ \text { RH103M } & 1.5 E+00 \\ \text { PD103 } & 8.4 E+00 \\ \text { I 129 } & 1.1 E+01 \\ \text { CS134 } & 2.5 E+03 \\ \text { CS135 } & 1.7 E-02 \\ \text { CS137 } & 2.9 E-01 \\ \text { BA137M } & 9.3 E+02 \\ \text { CE141 } & 6.1 E+01 \\ \text { SM151 } & 7.8 E-03 \\ \text { U 235 } & 1.1 E+02 \\ \text { TH231 } & 9.8 E+00 \\ \text { PA231 } & 4.0 E+01 \\ \text { AC227 } & 7.5 E-02 \\ \text { TH227 } & 1.2 E+02 \\ \text { FR223 } & 4.4 E+01 \\ \text { RA223 } & 1.3 E+02 \\ \text { NP237 } & 1.4 E+01 \\ \text { PA233 } & 2.7 E+02 \\ \text { U 233 } & 5.8 E-02 \\ \text { TH229 } & 1.1 E+01 \\ \text { RA225 } & 9.6 E+00 \\ \text { AC225 } & 9.4 E+00 \\ \text { U 238 } & 1.0 E-01 \\ \text { TH234 } & 4.7 E+00 \\ \text { PA234M } & 1.1 E+01 \\ \text { PA234 } & 2.5 E+03 \\ \text { PU242 } & 1.2 E-02 \\ \text { NP238 } & 7.2 E+02 \\ \text { PU238 } & 2.3 E-02 \\ \text { CM244 } & 2.6 E-02 \\ \text { PU244 } & 2.1 E-05 \\ \text { U 240 } & 6.0 E-01 \\ \text { PU240 } & 2.0 E-02 \\ \text { CM243 } & 1.3 E+02 \\ \text { PU243 } & 1.6 E+01 \\ \text { AM243 } & 2.6 E+01 \\ \text { NP239 } & 1.5 E+02 \\ \text { PU239 } & 2.1 E-02 \\ \text { PU241 } & 9.1 E-11 \\ \text { AM241 } & 1.2 E+01 \\ & \end{array}$


APFENDIX C - EXTERNAL DOSE RATE FACTOR LIBRARIES - BURIEDHFA

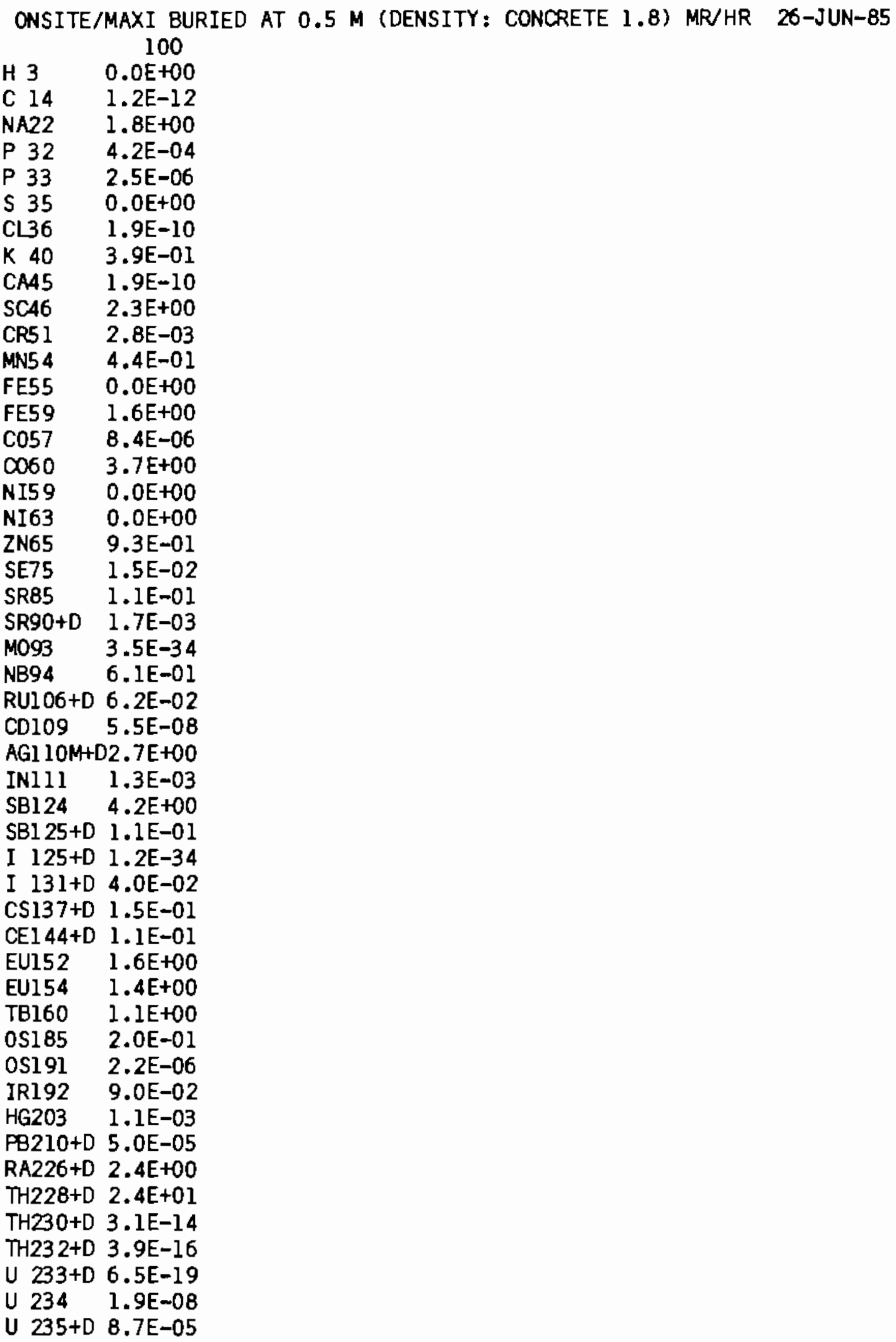


APPENDIX C - EXTERNAL DOSE RATE FACTOR LIBRARIES - BURIEDMFA

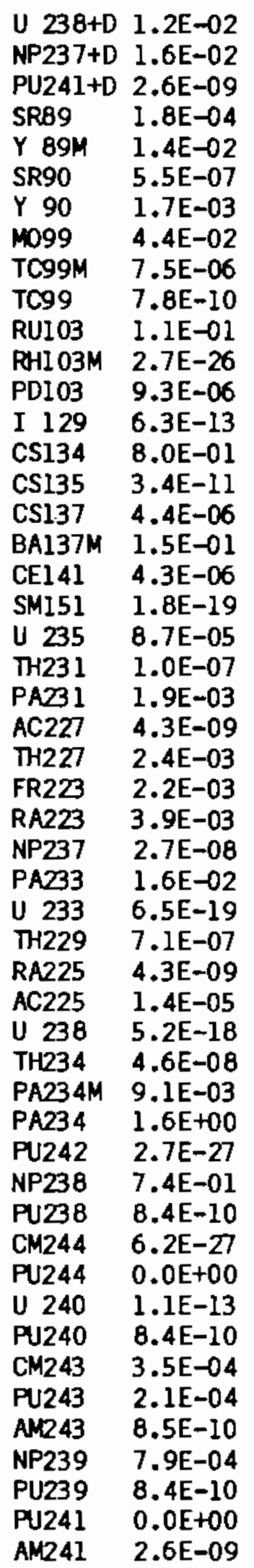


APPENDIX C - EXTERNAL DOSE RATE FACTOR LIBRARIES - BURIEDHFB

ONSITE/MAXI 1.0 M THICK BURIED AT 0.5 M (DEN: WATER 1.0) MR/HR 26-JUN-85 100

H $3 \quad 0.0 \mathrm{E}+00$

C $14 \quad 4.0 \mathrm{E}-12$

NA22 3.5E+00

P 32 9.5E-04

P $33 \quad 6.7 \mathrm{E}-06$

$5350.0 \mathrm{E}+00$

CL36 6.2E-10

K $40 \quad 8.2 \mathrm{E}-01$

CA45 6.3E-10

SC46 $4.5 \mathrm{E}+00$

CR5 1 7.DE-03

MN5 $4 \quad 9.8 \mathrm{E}-01$

FE55 $0.0 \mathrm{E}+00$

FE5 $3.0 E+00$

C057 2.8E-05

CO60 7.0E+00

NI59 $0.0 \mathrm{E}+00$

NI63 $0.0 \mathrm{E}+00$

ZN65 I.8E+00

SE75 3.9E-02

SR85 2.7E-01

SR90+D 3.6E-03

$\mathrm{MOS3}^{2} 2.2 \mathrm{E}-33$

NB9 $4 \quad 1.4 \mathrm{E}+00$

RU106+D 1.3E-01

CD109 2.0E-07

AGl 10M+D5.6E+00

INIII $3.8 \mathrm{E}-03$

$\mathrm{SB1} 24 \quad 8.6 \mathrm{E}+00$

SB1 25+D 2.6E-01

$1125+D 7.6 \mathrm{E}-34$

I $131+\mathrm{D} 9.9 \mathrm{E}-02$

$\mathrm{CS} 137+\mathrm{D} \quad 3.4 \mathrm{E}-\mathrm{Ol}$

CE144+D 2.2E-01

EU152 3.2E+00

EU154 2.6E+00

$\mathrm{TBl} 60 \quad 2.2 \mathrm{E}+00$

OS185 4.6E-01

OS191 7.2E-06

IRI92 2.3E-01

HG203 3.1E-03

PB210+D 1.2E-D4

RA226+D 4.9E+0D

$\mathrm{TH} 228+\mathrm{D} 4.6 \mathrm{E}+01$

$\mathrm{TH} 230+\mathrm{D} \quad 1.4 \mathrm{E}-13$

$\mathrm{TH} 232+\mathrm{D}$ 2.1E-15

U 233+D 3.5E-18

U $234 \quad 6.4 \mathrm{E}-08$

U $235+D \quad 2.5 E-04$ 
APPENDIX C - EXTERNAL DOSE RATE FACTOR LIBRARIES - BURIEDHFB

$\begin{array}{ll}\text { U 238+D } & 2.4 E-02 \\ \text { NP237+D } & 4.0 \mathrm{E}-02 \\ \text { PU241+D } & 8.7 \mathrm{E}-09 \\ \text { SR89 } & 4.3 \mathrm{E}-04 \\ \text { Y 89M } & 2.5 \mathrm{E}-02 \\ \text { SR90 } & 1.4 \mathrm{E}-06 \\ \text { Y 90 } & 3.6 \mathrm{E}-03 \\ \text { MO99 } & 1.0 \mathrm{E}-01 \\ \text { TC99M } & 2.5 \mathrm{E}-05 \\ \text { TC99 } & 2.4 \mathrm{E}-09 \\ \text { RU103 } & 2.7 \mathrm{E}-01 \\ \text { RH103M } & 1.8 \mathrm{E}-25 \\ \text { PD103 } & 2.3 \mathrm{E}-05 \\ \text { I 129 } & 2.2 \mathrm{E}-12 \\ \text { CS134 } & 1.8 \mathrm{E}+00 \\ \text { CS135 } & 1.1 \mathrm{E}-10 \\ \text { CS137 } & 1.1 \mathrm{E}-05 \\ \text { BA137M } & 3.6 \mathrm{E}-01 \\ \text { CE141 } & 1.4 \mathrm{E}-05 \\ \text { SM151 } & 8.2 \mathrm{E}-19 \\ \text { U 235 } & 2.5 \mathrm{E}-04 \\ \text { TH231 } & 3.5 \mathrm{E}-07 \\ \text { PA231 } & 4.8 \mathrm{E}-03 \\ \text { AC227 } & 1.4 \mathrm{E}-08 \\ \text { TH227 } & 6.1 \mathrm{E}-03 \\ \text { FR223 } & 5.1 \mathrm{E}-03 \\ \text { RA223 } & 1.0 \mathrm{E}-02 \\ \text { NP237 } & 9.3 \mathrm{E}-08 \\ \text { PA233 } & 4.0 \mathrm{E}-02 \\ \text { U 233 } & 3.5 \mathrm{E}-18 \\ \text { TH229 } & 2.4 \mathrm{E}-06 \\ \text { RA225 } & 1.3 \mathrm{E}-08 \\ \text { AC225 } & 4.1 \mathrm{E}-05 \\ \text { U 238 } & 2.8 \mathrm{E}-17 \\ \text { TH234 } & 1.5 \mathrm{E}-07 \\ \text { PA234M } & 1.7 \mathrm{E}-02 \\ \text { PA234 } & 3.3 \mathrm{E}+00 \\ \text { PU242 } & 1.8 \mathrm{E}-26 \\ \text { NP238 } & 1.4 \mathrm{E}+00 \\ \text { PU238 } & 2.8 \mathrm{E}-09 \\ \text { CM244 } & 4.1 \mathrm{E}-26 \\ \text { PU244 } & 0.0 \mathrm{E}+00 \\ \text { U 240 } & 3.6 \mathrm{E}-13 \\ \text { PU240 } & 2.8 \mathrm{E}-09 \\ \text { CM243 } & 1.0 \mathrm{E}-03 \\ \text { PU243 } & 5.3 \mathrm{E}-04 \\ \text { AM243 } & 3.4 \mathrm{E}-09 \\ \text { NP239 } & 2.1 \mathrm{E}-03 \\ \text { PU239 } & 2.8 \mathrm{E}-09 \\ \text { PU241 } & 0.0 \mathrm{E}+00 \\ \text { AM241 } & 8.7 \mathrm{E}-09\end{array}$


APPENDIX C - EXTERNAL DOSE RATE FACTOR LIBRARIES - BURIEDHFC

ONSITE/MAXI 1.0 M THICK BURIED 20.5 M (DEN: H20/CARBON 0.5/0.1) MR/HR 26-JUN-85

$\begin{array}{ll}\text { H } 3 & 100 \\ \text { C } 14 & 0.0 \mathrm{E}+00 \\ \text { NA22 } & 5.7 \mathrm{E}-12 \\ \text { P } 32 & 1.6 \mathrm{E}+00 \\ \text { P } 33 & 1.0 \mathrm{E}-03 \\ \text { S } 35 & 0.0 \mathrm{E}+00 \\ \text { CL36 } & 1.9 \mathrm{E}-05 \\ \text { K 40 } & 1.3 \mathrm{E}+00 \\ \text { CA45 } & 1.0 \mathrm{E}-09 \\ \text { SC46 } & 7.4 \mathrm{E}+00 \\ \text { CR51 } & 1.2 \mathrm{E}-02 \\ \text { MN54 } & 1.6 \mathrm{E}+00 \\ \text { FE55 } & 0.0 \mathrm{E}+00 \\ \text { FE59 } & 4.9 \mathrm{E}+00 \\ \text { CO57 } & 4.7 \mathrm{E}-05 \\ \text { CO60 } & 1.2 \mathrm{E}+01 \\ \text { NI59 } & 0.0 \mathrm{E}+00 \\ \text { NI63 } & 1.2 \mathrm{E}-21 \\ \text { ZN65 } & 2.9 \mathrm{E}+00 \\ \text { SE75 } & 6.6 \mathrm{E}-02 \\ \text { SR85 } & 4.6 \mathrm{E}-01 \\ \text { SR90+D } & 5.9 \mathrm{E}-03 \\ \text { M093 } & 3.9 \mathrm{E}-33 \\ \text { NB94 } & 2.3 \mathrm{E}+00 \\ \text { RU106+D } & 2.1 \mathrm{E}-01\end{array}$

RU106+D 2.1E-01

CD109 3.3E-07

$A G 110 M+D 9.1 E+00$

INIII 6.4E-03

SB124 1.4E+01

SB1 25+D 4.3E-01

I $125+\mathrm{D} \quad 1.3 \mathrm{E}-33$

I $131+\mathrm{D} 1.6 \mathrm{E}-01$

CS137+D 5.5E-01

CE144+D 3.6E-01

EUI52 5.2E+00

EU154 4.3E+00

TB160 3.7E+00

OS185 7.5E-01

$0 S 191 \quad 1.2 \mathrm{E}-05$

IRI92 3.8E-01

$\mathrm{HG} 203 \quad 5.2 \mathrm{E}-03$

PB210+D 2.0E-04

RA226+D 2.1E-03

$\mathrm{TH} 228+\mathrm{D}$ 1.2E+0I

TH230+D 2.4E-13

$\mathrm{TH} 232+\mathrm{D} \quad 3.6 \mathrm{E}-15$

U $33+D$ 5.9E-18

U 234 1.1E-07

U 235+D $4.2 \mathrm{E}-04$ 
APPENDIX C - EXTERNAL DOSE RATE FACTOR LIBRARIES - BURIEDHFC




APPENDIX C - EXTERNAL DOSE RATE FACTOR LIBRARIES - BURIEDIA

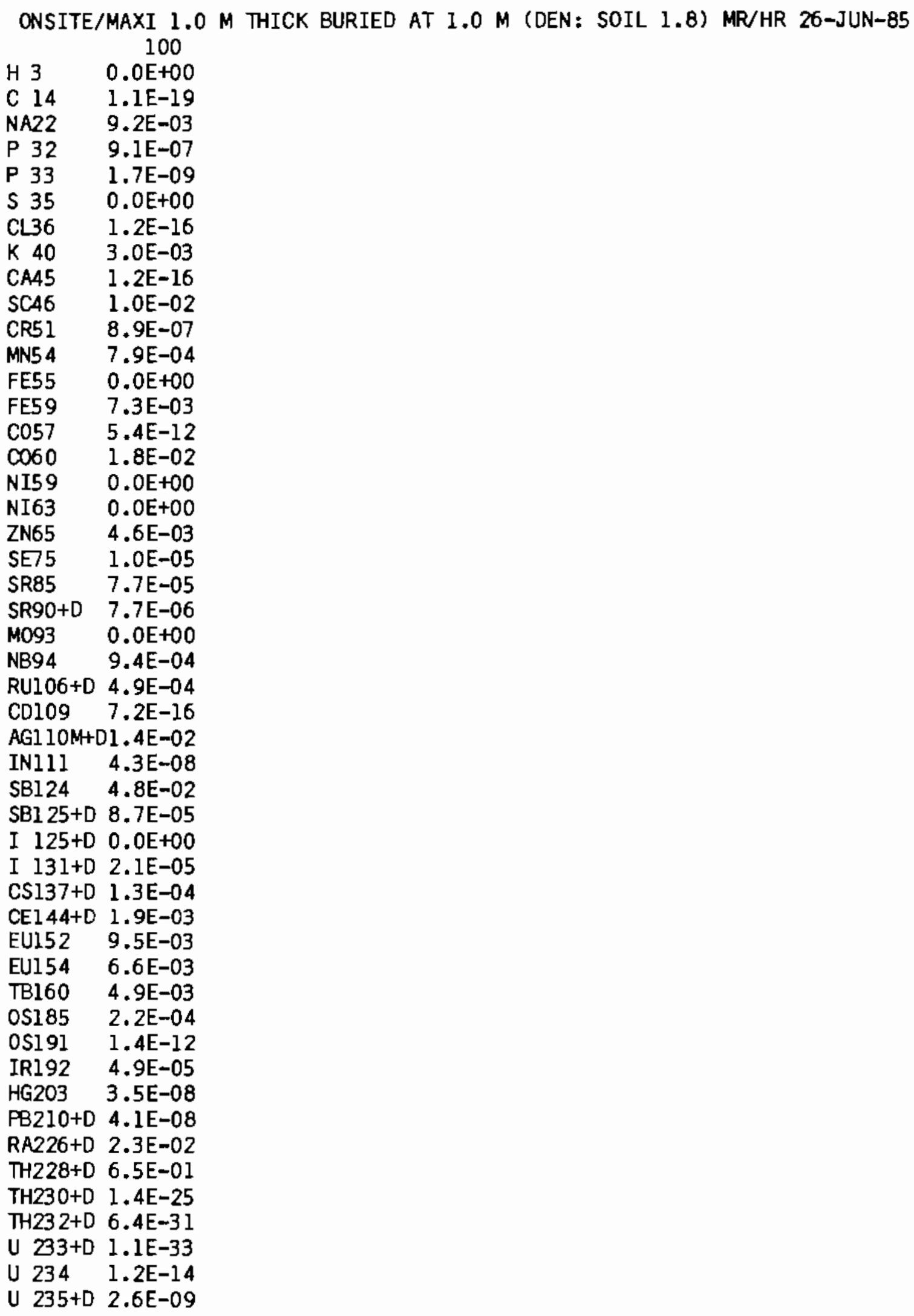


APPENDIX C - EXTERNAL DOSE RATE FACTOR LIBRARIES - BURIEDIA

$\begin{array}{ll}\text { U 238+D } & 5.3 E-05 \\ \text { NP237+D } & 5.7 E-06 \\ \text { PU241+D } & 1.6 E-15 \\ \text { SR89 } & 2.8 E-07 \\ \text { Y 89M } & 5.8 E-05 \\ \text { SR90 } & 1.5 E-10 \\ \text { Y 90 } & 7.7 E-06 \\ \text { M099 } & 6.6 E-05 \\ \text { TC99M } & 4.9 E-12 \\ \text { TC99 } & 1.3 E-14 \\ \text { RU103 } & 7.9 E-05 \\ \text { RH103M } & 0.0 E+00 \\ \text { PD103 } & 3.0 E-09 \\ \text { I 129 } & 4.2 E-20 \\ \text { CS134 } & 2.1 E-03 \\ \text { CS135 } & 1.9 E-17 \\ \text { CS137 } & 4.1 E-09 \\ \text { BA137M } & 1.3 E-04 \\ \text { CE141 } & 9.3 E-11 \\ \text { SM151 } & 7.8 E-30 \\ \text { U 235 } & 2.6 E-09 \\ \text { TH231 } & 6.0 E-14 \\ \text { PA231 } & 6.0 E-07 \\ \text { AC227 } & 2.7 E-15 \\ \text { TH227 } & 6.5 E-07 \\ \text { FR223 } & 3.6 E-06 \\ \text { RA223 } & 1.7 E-06 \\ \text { NP237 } & 1.6 E-15 \\ \text { PA233 } & 5.7 E-06 \\ \text { U 233 } & 1.1 E-33 \\ \text { TH229 } & 4.6 E-13 \\ \text { RA225 } & 1.2 E-13 \\ \text { AC225 } & 4.6 E-10 \\ \text { U 238 } & 8.5 E-33 \\ \text { TH234 } & 1.6 E-14 \\ \text { PA234M } & 3.6 E-05 \\ \text { PA234 } & 8.2 E-03 \\ \text { PU242 } & 0.0 E+00 \\ \text { NP238 } & 3.2 E-03 \\ \text { PU238 } & 5.4 E-16 \\ \text { CM244 } & 0.0 E+00 \\ \text { PU244 } & 0.0 E+00 \\ \text { U 240 } & 6.4 E-21 \\ \text { PU240 } & 5.4 E-16 \\ \text { CM243 } & 1.1 E-08 \\ \text { PU243 } & 6.7 E-08 \\ \text { AM243 } & 4.3 E-19 \\ \text { NP239 } & 1.5 E-07 \\ \text { AM2431 } & 5.4 E-16 \\ \text { PU241 } & 1.6 E-15\end{array}$


APPENDIX C - EXTERNAL DOSE RATE FACTOR LIBRARIES - BURIEDIB

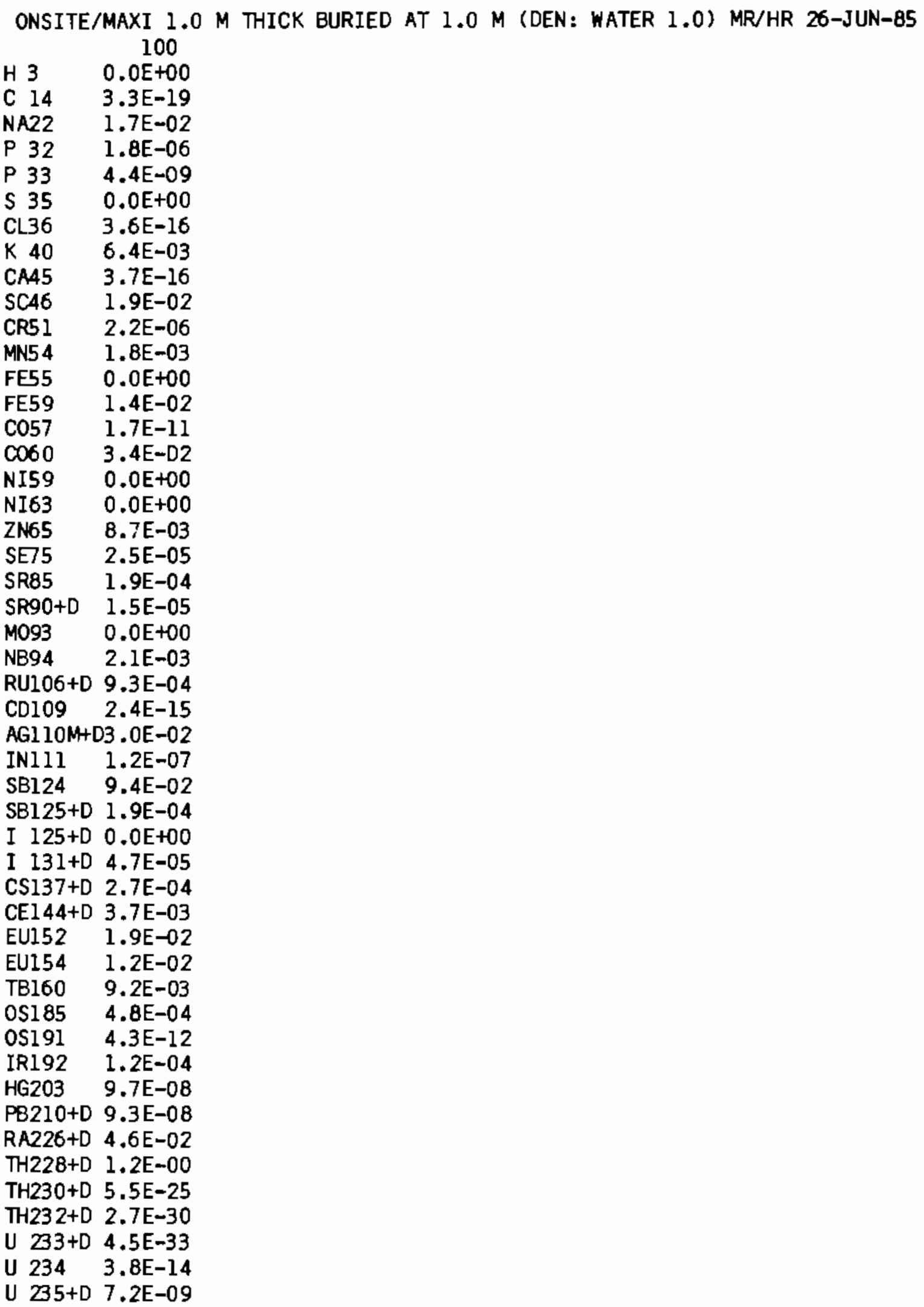


APPENDIX C - EXTERNAL DOSE RATE FACTOR LIBRARIES - BURIEDIB

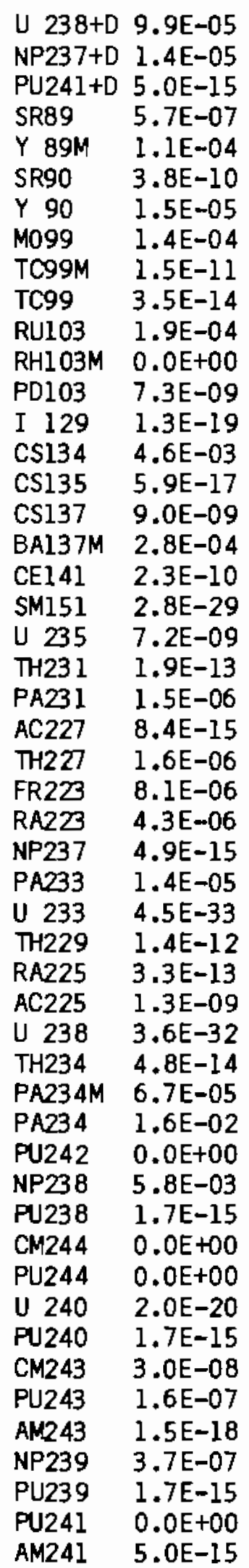


APPENDIX C - EXTERNAL DOSE RATE FACTOR LIBRARIES - BURIEDIC

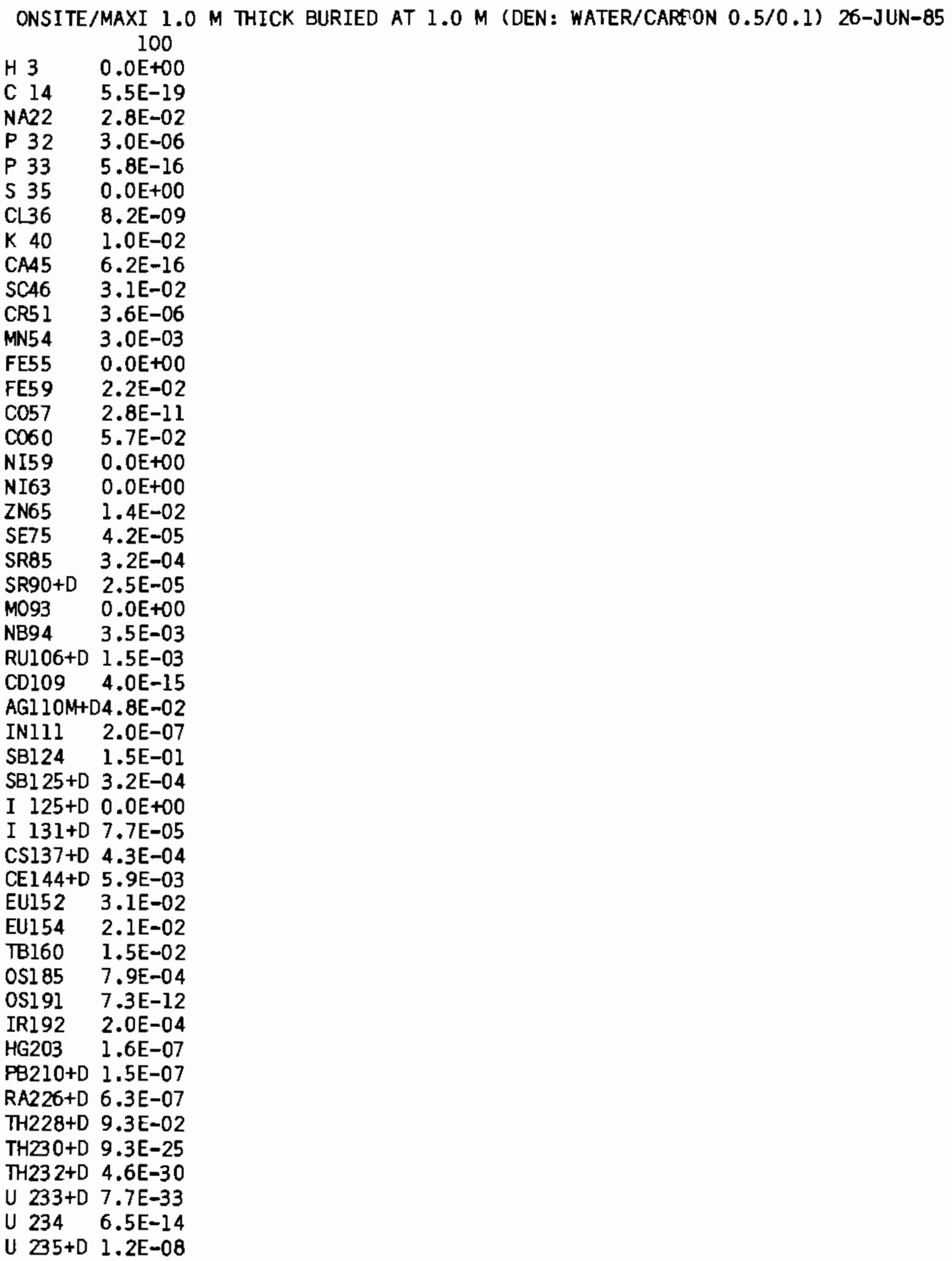


APPENDIX C - EXTERNAL DOSE RATE FACTOR LIBRARIES - BURIEDIC

$\begin{array}{ll}\text { U 238+D } & 1.6 \mathrm{E}-04 \\ \text { NP237+D } & 2.3 \mathrm{E}-05 \\ \text { PU241+D } & 8.5 \mathrm{E}-15 \\ \text { SR89 } & 9.5 \mathrm{E}-07 \\ \text { Y 89M } & 1.8 \mathrm{E}-04 \\ \text { SR90 } & 6.4 \mathrm{E}-10 \\ \text { Y 90 } & 2.5 \mathrm{E}-05 \\ \text { MO99 } & 2.3 \mathrm{E}-04 \\ \text { TC99M } & 2.5 \mathrm{E}-11 \\ \text { TC99 } & 5.9 \mathrm{E}-14 \\ \text { RU103 } & 3.2 \mathrm{E}-04 \\ \text { RH103M } & 0.0 \mathrm{E}+00 \\ \text { PD103 } & 1.2 \mathrm{E}-08 \\ \text { I 129 } & 2.2 \mathrm{E}-19 \\ \text { CS134 } & 7.5 \mathrm{E}-03 \\ \text { CS135 } & 1.0 \mathrm{E}-16 \\ \text { CS137 } & 1.5 \mathrm{E}-08 \\ \text { BA137M } & 4.6 \mathrm{E}-04 \\ \text { CE141 } & 3.9 \mathrm{E}-10 \\ \text { SM151 } & 4.7 \mathrm{E}-29 \\ \text { U 235 } & 1.2 \mathrm{E}-08 \\ \text { TH231 } & 3.1 \mathrm{E}-13 \\ \text { PA231 } & 2.5 \mathrm{E}-06 \\ \text { AC227 } & 1.4 \mathrm{E}-14 \\ \text { TH227 } & 2.7 \mathrm{E}-06 \\ \text { FR223 } & 1.3 \mathrm{E}-05 \\ \text { RA223 } & 7.1 \mathrm{E}-06 \\ \text { NP237 } & 8.3 \mathrm{E}-15 \\ \text { PA233 } & 2.3 \mathrm{E}-05 \\ \text { U233 } & 7.7 \mathrm{E}-33 \\ \text { TH229 } & 2.4 \mathrm{E}-12 \\ \text { RA225 } & 5.5 \mathrm{E}-13 \\ \text { AC225 } & 2.1 \mathrm{E}-09 \\ \text { U238 } & 6.2 \mathrm{E}-32 \\ \text { TH234 } & 8.1 \mathrm{E}-14 \\ \text { PA234M } & 1.1 \mathrm{E}-04 \\ \text { PA234 } & 2.6 \mathrm{E}-02 \\ \text { PU242 } & 0.0 \mathrm{E}+00 \\ \text { NP238 } & 9.6 \mathrm{E}-03 \\ \text { PU238 } & 2.8 \mathrm{E}-15 \\ \text { CM244 } & 0.0 \mathrm{E}+00 \\ \text { PU244 } & 0.0 \mathrm{E}+00 \\ \text { U 240 } & 4.5 \mathrm{E}-11 \\ \text { PU240 } & 2.8 \mathrm{E}-15 \\ \text { CM243 } & 5.1 \mathrm{E}-08 \\ \text { PU243 } & 2.8 \mathrm{E}-07 \\ \text { AM243 } & 2.6 \mathrm{E}-18 \\ \text { NP239 } & 6.2 \mathrm{E}-07 \\ \text { PU239 } & 2.8 \mathrm{E}-15 \\ \text { PU241 } & 0.0 \mathrm{E}+00 \\ \text { AM241 } & 8.5 \mathrm{E}-15 \\ & \end{array}$


NUREG/CR-3620

PNL-4054 SUPP 1. 1

RE, RH, RW

\section{DISTRIBUTION}

No. of

Coptes

OFESIIE

U.S. Nuclear Regulatory Commission

Division of Technical Information and Document Control

7920 Norfolk Avenue

Bethesda, MO 20014

10 S. M. Neuder

U.S. Nuclear Regulatory Commisston

Division of Waste Management Office of NMSS

Washington, DC 20555

J. D. Randall

U.S. Nuclear Regulatory Commission

Mail Stop 1130 SS

Washington, DC 20555

Director, Office of NMSS

U.S. Nuclear Regulatory Commission

Washington, DC 20555

Director, Division of Waste Management

U.S. Nuclear Regulatory

Commisstion

Washington, DC 20555
No. of

Coptes

ONSITE

50 Pacific Northwest Laboratory

J. B. Brown, Jr.

D. W. Dragnich

L. G. Faust

P. C. Hays

G. R. Hoenes

R. L. Kathren

W. E. Kennedy, Jr. (10)

L. T. Lakey

J. M. Latkovich

B. A. Napier (10)

R. A. Peloquin (10)

R. G. Schreckhise

J. M. Seiby

J. K. Soldat

S. L. Stein

Publishing Coordination (2)

Technical Information (5) 



\begin{tabular}{|c|c|c|c|}
\hline \multirow{3}{*}{\multicolumn{2}{|c|}{ 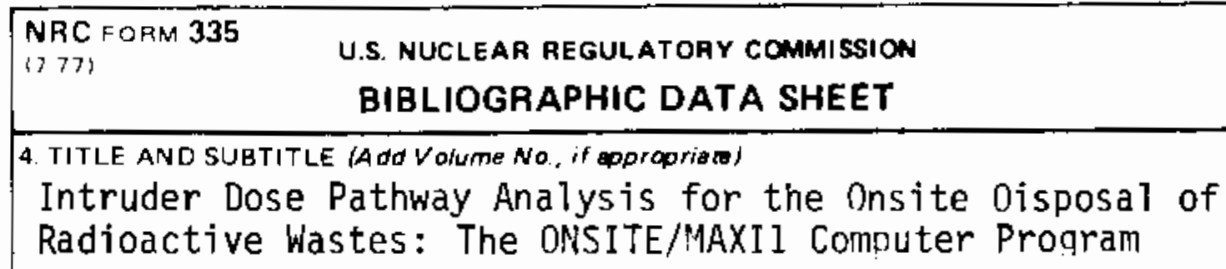 }} & \multicolumn{2}{|c|}{$\begin{array}{l}\text { 1. REPORT NUMBEF (Assigned by ODC) } \\
\text { NUREG/CR }-3620 \text {, SUPP. No. } 1 \\
\text { PNL }-4054\end{array}$} \\
\hline & & \multicolumn{2}{|l|}{ 2. (Leave biank) } \\
\hline & & \multicolumn{2}{|c|}{ 3. RECIPIENT'S ACCESSION NO. } \\
\hline \multicolumn{2}{|c|}{$\begin{array}{l}\text { 7. AUthOR }(S) \\
\text { W. E. Kennedy, Jr., R. A. Peloquin, B. A. Napier/PNL } \\
\text { S. Neuder/NRC }\end{array}$} & $\begin{array}{l}\text { MONTH } \\
\text { Apri } 1 \\
\end{array}$ & $\begin{array}{ll}\text { OMPLE TED } \\
\text { YEAR } \\
\end{array}$ \\
\hline \multirow{2}{*}{\multicolumn{2}{|c|}{$\begin{array}{l}\text { 9. PERFORMING ORGANIZATION NAME AND MAILING ADDRESS (include Zip Code) } \\
\text { Pacific Northwest Laboratory } \\
\text { P.0. Box } 999 \\
\text { Richland, HA } 99352\end{array}$}} & $\begin{array}{l}\text { DATE REPOHT IS } \\
\text { MONTH } \\
\text { MaY }\end{array}$ & 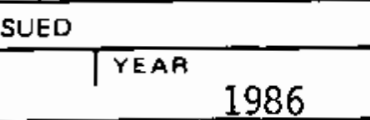 \\
\hline & & \multicolumn{2}{|l|}{ 6. (Lesve brank) } \\
\hline & & \multicolumn{2}{|l|}{ 8. (Leave biank) } \\
\hline \multirow{2}{*}{\multicolumn{2}{|c|}{$\begin{array}{l}\text { 12. SPONSORING ORGANIZATION NAME AND MAILING ADDRESS (inciude } Z i p \text { Code) } \\
\text { Division of Waste Management } \\
\text { Office of Nuclear Material Safety and Safeguards } \\
\text { U.S. Nuclear Regulatory Commission } \\
\text { Washington, D.C. } 20555\end{array}$}} & \multicolumn{2}{|c|}{ 10. PROJECT/TASK/WORK UNIT NO. } \\
\hline & & \multicolumn{2}{|l|}{$\begin{array}{l}\text { 11. CONTRACT NO. } \\
\text { FIN B2478 }\end{array}$} \\
\hline \multicolumn{4}{|l|}{ 13. TYPE OF REPORT } \\
\hline \multicolumn{2}{|l|}{ 15. SUPPLEMENTARY NOTES } & \multicolumn{2}{|l|}{ 14. (Leave blank) } \\
\hline \multicolumn{4}{|c|}{$\begin{array}{l}\text { 16. ABSTRACT } 200 \text { words or iess) } \\
\text { Whe document entitled Intruder Dose Pathway Analysis of the Onsite Disposal of Radioactive } \\
\text { Wastes: The ONSITE/MAXII Computer Program (1984) by Napier et al. summarizes our injtial } \\
\text { efforts to develop human-intrusion scenarios and a modified version of the MAXI computer } \\
\text { program for potential use by the NRC in reviewing applications for onsite radioactive } \\
\text { waste disposal. This document is a supplement to that document and summarizes our efforts } \\
\text { to further modify and improve the ONSITE/MAXI1 software package. To facilitate cross- } \\
\text { referencing, it follows the same format. Notable improvements to the software package } \\
\text { include the capability to account for shielding conditions that represent noncompacted } \\
\text { trash wastes and the option to indicate alternative land-use conditions. This supplement } \\
\text { contains a description of the implementation of these modifications. In addition, a } \\
\text { series of discussions are included in an attempt to increase the user's understanding of } \\
\text { the scenarios and dose calculation methods. These discussions respond to frequently asked } \\
\text { questions about the mathematical models and use of the software. Computer listings of the } \\
\text { ONSITE/MAXI1 computer program are inciuded as Appendices A and B of this document. } \\
\text { Appendix C lists external exposure dose-rate factor libraries. }\end{array}$} \\
\hline \multicolumn{4}{|c|}{$\begin{array}{l}\text { 17. KEY WORDS AND DOCUMENT ANALYSIS } \\
\text { ONSITE/MAXI1 computer program } \\
\text { onsite radioactive waste disposal }\end{array}$} \\
\hline \multicolumn{4}{|c|}{ 17b. IDENTIFIEAS/OPEN-ENOED TERMS } \\
\hline \multirow{2}{*}{$\begin{array}{l}\text { 18. AVAILABILITY STATEMENT } \\
\text { Untimited }\end{array}$} & \multirow{2}{*}{\multicolumn{2}{|c|}{  }} & 21. NO. OF PAGES \\
\hline & & & $\begin{array}{c}\text { 22. PRICE } \\
S\end{array}$ \\
\hline
\end{tabular}


